DOUGLAS CAMARINHA GONZALES

\title{
COMPETÊNCIA LEGISLATIVA DOS ENTES FEDERADOS; CONFLITOS E INTERPRETAÇÃO CONSTITUCIONAL
}

\author{
Dissertação de Mestrado
}

Orientadora: Profa. Dra. Anna Cândida da Cunha Ferraz

Faculdade de Direito da Universidade de São Paulo

São Paulo - 2011 
DOUGLAS CAMARINHA GONZALES

\title{
COMPETÊNCIA LEGISLATIVA DOS ENTES FEDERADOS; CONFLITOS E INTERPRETAÇÃO CONSTITUCIONAL
}

\begin{abstract}
Dissertação de Mestrado apresentada à Banca Examinadora do Departamento de Direito de Estado da Faculdade de Direito da Universidade de São Paulo, como exigência parcial para a obtenção do título de Mestre em Direito do Estado, sob a orientação da Professora Doutora Anna Cândida da Cunha Ferraz.
\end{abstract}

Faculdade De Direito da Universidade de São Paulo São Paulo - 2011 
Resumo

Esta dissertação dedica-se ao estudo das competências legislativas no âmbito do federalismo brasileiro e à interpretação constitucional que dita a solução de possíveis conflitos legislativos. O trabalho foca inicialmente o federalismo brasileiro e a divisão constitucional de competências entre os entes federados - suas origens, características e peculiaridades. Estuda-se, dessa forma, a competência legislativa de cada ente federado, da União, dos Estados, dos Municípios e do Distrito Federal. Procura-se, pois, compreender o funcionamento do sistema de repartição de competências, suas técnicas e princípios, para se alcançar o balanceamento necessário para um federalismo de equilíbrio almejado pelo constituinte. Fiel aos fundamentos do federalismo nacional, o estudo aborda o papel da Hermenêutica Constitucional para a solução de conflitos entre os entes federados. O trabalho busca, assim, visualizar resultados que otimizem as diretrizes constitucionais do federalismo, mediante a aplicação dos seus princípios e de métodos que auxiliem o jurista no processo interpretativo para solucionar confrontos jurídicos entre os entes federados. O estudo parte de uma análise sistemática dos dogmas do federalismo em sintonia com a Teoria da Argumentação para, dessa maneira, examinar diversas querelas judiciais de conflitos legislativos e sugerir possíveis soluções.

Palavras-chave: federalismo - competência - conflito - interpretação. 


\begin{abstract}
The aim of this paper is to study the Legislative jurisdiction, which rules the solution of possible conflicts within its Political Entities, in the Brazilian Federalism and the Constitutional Interpretation. Initially, the foccus is on the Brazilian Federalism and the Constitutional jurisdiction in the role of the Federalism, its origin, characteristics and particularities.The Dissertation studies the Legislative jurisdiction of each Political Entity, the Union, the States, the Municipal District and Federal District. The essay looks for to comprehend the system frame of competences, its techinics and principles wich work to reach the necessary balance to a Federalism with the equilibrium desired by the Constitution's Representative. Faithfull to the basis of the National Federalism, the essay takes the Constitutional Interpretation in approach to lead and solve conflicts among the Political Entities. Therefore, the study looks for results which optimize the Federalism assertive, through principles and methods that help the interpreter in the process to solve Legislative conflicts among Political Entities in the Federalism. The study goes on through a systematic view of the dogmas of the Federalism according to Argumentation Theory to examine several legislative conflicts and propose possible solutions.
\end{abstract}

Keywords: federalism - conflict - competence - interpretation. 


\section{SUMÁRIO}

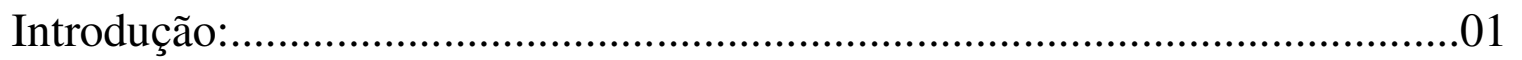

Capítulo I - O Estado Federal

1.1 Origem e Características .04

1.2 Evolução do Federalismo e a Repartição de Competências.

Capítulo II - A Repartição de Competências na Constituição Federal de 1988

2.1 O Modelo de Repartição de competências adotado pelo Brasil...........18

2.2 A Competência Legislativa Privativa da União...................................20

2.3 A Competência Legislativa Privativa Estadual....................................27

2.4 A Competência Legislativa Privativa do Distrito Federal....................36

2.5 A Competência Legislativa Privativa Municipal..................................38

2.6 A Competência Legislativa Concorrente

2.6.1 Aspectos Gerais. 43

2.6.2. Sistemática e Funcionamento da Competência

Legislativa Concorrente ............................................................46

2.7 Competências Materiais ou Legislativas Decorrentes...........................57

2.7.1 Competência Material da União..................................................58

2.7.2 Competência Material dos Estados e do Distrito Federal...........64

2.7.3 Competência Material dos Municípios..........................................70

2.7.4 Competência Material Comum dos Entes Federados..................72

Capítulo III - Interpretação Constitucional e Soluções de Conflitos

3.1 A Neo-interpretação Jurídica Constitucional..................................76

3.2 Multiplicidade de Centros Normativos.........................................94

3.3 As Antinomias e a Taxionomia na Análise dos Conflitos.............98

3.4 Limites Objetivos, um Ponto de Equilíbrio....................................106 
3.5 Peculiaridades Interpretativas das Normas Municipais no

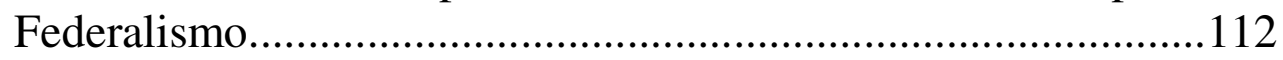

3.6 Antinomias e a Competência Concorrente.....................................118

3.7 Notas sobre as Competências Legislativas Indiretas......................128

3.8 Antinomias de Normas Estaduais versus Normas Privativas da

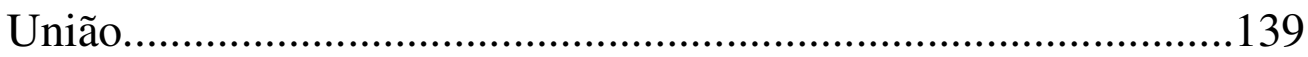

3.9 Tratados Internacionais e a Solução de Conflitos...........................145

3.9.1 Interpretação dos Tratados.................................................147

3.9.2 A Aplicação dos Tratados Frente aos Entes Federados.........155

Conclusões

Bibliografia 165 


\section{Introdução:}

O presente trabalho estuda a repartição da competência legiferante positivada pelo constituinte, decorrente do modelo de Estado encampado pela Carta Política de 1988, que adotou o federalismo de equilíbrio. O estudo busca aclarar critérios e métodos de interpretação constitucional para solucionar possíveis antinomias jurídicas advindas da múltipla positivação de normas pelos entes federados.

O trabalho inicia-se com o exame do Estado Federal e a correspondente análise da divisão de competências legislativas entre os entes federados, sua concepção original, suas características e sua evolução. Aborda, assim, a trajetória do federalismo brasileiro, as peculiaridades da distribuição de competências, a divisão de forças políticas entre os entes federados e as críticas daí decorrentes.

As principais características para a manutenção salutar do sistema federativo são apontadas no decorrer do trabalho para se atingir o binômio do federalismo - a unidade na diversidade - baseado no equilíbrio de unidade na Federação e autonomia dos entes políticos.

Procura-se, assim, encontrar os fundamentos lançados pelo constituinte na repartição de competências, sob os reclamos do federalismo de equilíbrio e o redimensionamento atribuído pela nova ordem constitucional brasileira. Sob esse enfoque, analisa-se o modelo federativo nacional perfilhado pelo complexo sistema de repartição de competências que congrega critérios de ótica horizontal e vertical para a partilha das competências, contempla hipóteses de delegação de competência da União aos Estados-membros e outras formas de cooperação administrativa.

O estudo então se foca na competência legislativa privativa dos entes federados, inicialmente da União frente ao seu papel institucional de coesão nacional sobre assuntos que demandam interesse nacional.

Em seguida, parte-se para a análise da competência legislativa dos Estados-membros na busca da competência legislativa remanescente no concerto da federação e das diretrizes condicionantes da Constituição Federal na formatação da autonomia dos entes federados. Traçam-se, ainda, os pontos essenciais sobre as competências legislativas do Distrito Federal.

Por sua vez, o estudo volta-se à competência legislativa municipal, sob a perquirição do interesse municipal para balizar a legitimidade da lei municipal no concerto com as demais. 
Em item específico, procura-se compreender o funcionamento do sistema de repartição vertical de competências, principal inovação da ordem constitucional vigente, tida como alternativa criativa para se alcançar o balanceamento necessário para um federalismo de equilíbrio e a co-responsabilidade dos entes federativos nas diferentes searas que atuam conjuntamente.

O estudo foca a prerrogativa da União de editar normas gerais e a dos Estadosmembros de elaborar normas específicas, a elas complementares; a definição de seus limites e de seus alcances, conforme a leitura do Supremo Tribunal Federal das regras do artigo 24, $\S \S$ 1..$^{\circ}$ e $2^{\circ}$, da Constituição Federal de 1988 - para a análise das consequiências políticas à Federação.

Aborda-se ainda a competência material dos entes federados, da qual emana a competência legislativa decorrente para o exercício funcional de tais atribuições. Parte-se, assim, para uma visão dessas implicações materiais e legislativas próprias da União, dos Estados e dos Municípios, e se traça possíveis conflitos daí decorrentes.

A discussão é enriquecida com as implicações legislativas do sistema de cooperação entre os entes federados no regime da região metropolitana e a execução de funções públicas de interesse comum.

Já a segunda parte do trabalho dedica-se à temática da interpretação jurídicoconstitucional das competências legislativas a partir da leitura dos métodos da neohermenêutica constitucional, baseada no contexto fático, valorativo e principiológico que o intérprete depara na análise das possíveis antinomias que os multicentros normativos podem originar.

São traçadas as abordagens que melhor amparam a divisão constitucional de competência, de modo a resguardar a efetiva distribuição de poderes e prerrogativas dos entes federados, na busca de um resultado que otimize as diretrizes constitucionais apresentadas nos capítulos anteriores para solucionar possíveis conflitos.

Fiel às origens do federalismo e sua interpretação constitucional, sugere-se soluções hermenêuticas e principiológicas para solução de conflitos; as críticas aos preceitos normativos que geram insegurança normativa e a conseqüente repercussão política na conjugação dessas forças. 
O trabalho procurará trazer exemplos marcantes colhidos da jurisprudência nacional e do Direito Comparado, como forma de ilustrar possíveis conflitos de leis entre os entes federados, seja entre lei federais versus estaduais ou sua recíproca e a interação das municipais sobre o mesmo assunto.

A interpretação constitucional para as soluções dos conflitos é tratada de modo específico para ampliar ao intérprete visão sensata para desvendar a aplicação das normas frente aos conflitos, segundo os dogmas do próprio federalismo.

Por fim, as interações dos Tratados Internacionais no ordenamento jurídico brasileiro são analisadas frente às competências legislativas, seus limites e confrontos. Examina-se assim a natureza jurídica dos tratados em que a República Federativa do Brasil é signatária, seus desdobramentos no encaixe das normas positivadas pelos demais entes federados e o posicionamento do Supremo Tribunal Federal no controle abstrato de constitucionalidade dos Tratados. 


\section{Capítulo I - O Estado Federal \\ 1.1 Origem e Características}

O estudo da divisão do poder dentro do Estado sob o prisma territorial desdobra-se sobre a história político-jurídica dos contornos do Estado e sua evolução. A idéia de divisão vertical de competências legislativas só surge efetivamente com a eclosão do fenômeno político, histórico e jurídico do federalismo, pois antes se trabalhava ora com meras divisões administrativas, ora com a idéia de alianças e de pactos, onde não se estabelecia vínculos duradouros ou seguros o suficiente para assegurar a autonomia dos entes partes ${ }^{1}$.

A História não destaca relevantes aspectos de divisão do poder político ao longo do território de um mesmo Estado, vinculado a uma única soberania. O Estado Grego Antigo constituído pela Polis não viabiliza a divisão geográfica do poder; o Estado Romano representa a expressão máxima da concentração política e econômica da Idade Antiga, pois em que pese o intercâmbio cultural entre os dominados e dominadores, perante o Direito, Roma legisla autonomamente. Já o Estado Medieval caracteriza-se pela marcante descentralização de forças sob o jugo do feudalismo que alguns autores consideram o desaparecimento ou quase desaparecimento do Estado $^{2}$. A fragmentação do poder é a tônica do feudalismo, cuja união só advinha efetivamente em prol de necessidade militar, de forma que não se divisa competências jurídicas definidas.

A Idade Moderna marchou sob as matizes do Estado Unitário, marcado pela centralização política, onde se nota apenas a descentralização administrativa, fincada no governo único, cuja admissão da legislação local faz-se sob o jugo do poder central. Sua base jurídica promanava de delegação jurídica e não da Constituição, de forma que se constata apenas distribuição de competência administrativa, mas não a autonomia legislativa propriamente dita das entidades políticas.

Como se vê, em período pregresso ao federalismo, a divisão de competências legais e administrativas pendia, em linha tênue, de permissividade do poder central, como uma espécie de longa manus da autoridade central. Antes do federalismo não se assistiu a uma verdadeira

\footnotetext{
${ }^{1}$ O exemplo mais marcante é a própria Confederação, criada em 1777 pelas ex-colônias britânicas, então sucedida pela criação dos Estados Unidos da América, através da Convenção de Filadélfia em 1787.

${ }^{2}$ É o que se infere de: MALUF, Sahid. Teoria Geral do Estado. $8^{\circ}$ Ed. São Paulo: Sugestões Literários, 1974, p. 125.
} 
descentralização política do poder, mas apenas a experiências de descentralização administrativa, sob o jugo do poder central. Por sua vez, a idéia de união de Estados era efêmera, pois baseada em determinados propósitos (em geral militares ou econômicos), e não na descentralização estatal propriamente dita.

Somente com o surgimento do Federalismo emerge a sólida divisão jurídica da repartição de competências administrativas e legiferantes ao longo do território do Estado, fundada na mais complexa estrutura governamental então conhecida. Cuida-se, pois, de fenômeno histórico, político e jurídico a criação do Estado Federal.

O federalismo surgiu, pois, de um contexto histórico-político - a declaração de independência das antigas colônias inglesas frente à ameaça bélica britânica - de forma que a idéia inicial da Confederação mostrou-se insuficiente e desarticulada para fazer frente ao poderio inglês.

Foi graças à contribuição ideológica de Alexander Hamilton, Jonh Jay e James Madison, os federalistas, através de artigos publicados na imprensa e posteriormente reunidos na obra $\mathrm{O}$ Federalista ${ }^{3}$, que o mundo assistiu à inauguração de um novo modelo institucional de Estado, definido a partir da descentralização político-administrativa de cada Estado-parte e de sua projeção de poder dentro da esfera territorial - daí nasceu nova forma de Estado, o Estado Federal para fazer frente ao Estado Unitário, cuja originalidade é a construção de um Estado soberano composto por Estados autônomos, devidamente garantida por um pacto constitucional que condensa a repartição de competências legislativas dos seus membros, e, em consequência, a descentralização político-administrativa dos entes federados.

Só assim se superou a maior angústia das antigas ex-colônias ao neomodelo institucional de Estado, qual seja, o temor de que sua incorporação ao novo Estado que se pretendia criar implicasse no retorno a um estado de submissão e afronta à sua independência. Tal impasse foi contornado através da garantia constitucional de efetiva autonomia aos Estados-membros, calcada na preservação da capacidade de autogoverno, ditada pela descentralização política do Estado-membro e na sua capacidade de auto-organização.

\footnotetext{
${ }^{3}$ HAMILTON, Alexander; MADISON, James; JAY, John. O Federalista. Brasília. Trad. de Heitor Herrera. Brasília: Universidade de Brasília, 1984.
} 
Diante do sucesso do modelo inaugural, outros Estados também assumiram essa forma de organização, mas com particularidades decorrentes do Poder Constituinte Originário ${ }^{4}$, de sorte que não se pode delinear o federalismo como um conceito modelo e único firmado pelo surgimento do Estado norte-americano, mas como modelo inicial que deu ensejo a uma organização política verdadeiramente nova e rompeu o pensamento político do Estado unitário.

A peculiaridade da forma do Estado Federal para cada país é uma lógica ditada pela dialética histórica, política e cultural que deu forma ao Poder Constituinte Originário e à sua contínua estabilização.

Karl Lowenstein ${ }^{5}$ observa que o federalismo constitui uma forma de divisão espacial e de controle vertical do poder público. A divisão ocorre a partir da existência de diversos núcleos políticos, sendo um deles de caráter central, que edita normas aplicáveis em todo o território nacional, e os demais de caráter local, cujas normas e ações ficam circunscritas $a$ suas próprias regiões do Estado parte. Cada centro de poder constitui um ente federado, com capacidade de auto-organização e com atribuições delineadas na Constituição. A distribuição espacial de poder entre os entes federados permite a realização de um controle político mútuo, que, pela existência de um ente central e de entes parciais, pode ser denominado vertical.

Daí as palavras de Kelsen na qual o Estado Federal contém o ordenamento jurídico total, o ordenamento jurídico central e ordenamento jurídico parcial. O Estado Federal, a comunidade jurídica total, compreende a Federação, que é a comunidade jurídica central, e os Estados-membros, que formam comunidades jurídicas parciais ${ }^{6}$.

Diante dos caracteres comuns do federalismo, a doutrina ${ }^{7}$ equaciona os seus principais elementos: a repartição constitucional de competências e de rendas; a possibilidade de auto-

\footnotetext{
${ }^{4}$ Nesse sentido é o pronunciamento do Supremo Tribunal Federal, em sede de deliberação sobre a cláusula pétrea da forma federativa de Estado, ao frisar que esta "não pode ser conceituada a partir de um modelo ideal e apriorístico de Federação, mas, sim, daquele que o constituinte originário concretamente adotou, e como adotou" (ADI 2.024, liminar, DJ de $1^{\mathrm{a}} .12 .2000$ ).

${ }^{5}$ LOEWENSTEIN, Karl. Teoria de la Constituición. Barcelona: Ed. Ariel S/A, 1986, p. 353. Pondera o jurista : "El federalismo: el enfrantamiento entre dos soberanías diferentes estatales separadas territoriamente y que se equilibran mutuamente. La existência de fronteras federales limita el poder del Estado central sobre el Estado miembro, y la inversa."

${ }^{6}$ KELSEN apud HORTA, Raul Machado. Repartição de Competências na Constituição Federal de 1988. Revista Trimestral de Direito Público no 2. Malheiros, 1993, p 6.

7 Nesse sentido, Cf. ARAÚJO, Luiz Alberto David; NUNES JUNIOR, Vidal Serrano. Curso de Direito Constitucional. 13 ed., São Paulo: Saraiva, 2009.
} 
organização dos entes políticos; a indissolubilidade do vínculo; a participação da vontade das ordens parciais na elaboração da norma geral, a existência de um tribunal constitucional. Loewenstein sintetiza a relevância da primeira característica ao expressar que:

\begin{abstract}
Ningúm Estado federal puede funcionar sem una constitución escrita, esta es la encarnación del contrato sobre la 'alianza eterna'. Por medio de este pacto, los Estados miembros, hasta entonces soberanos, prescindem de ciertos derechos inerentes a su soberania em favor del Estado central, siendo compensados al estar protegida su existência por todos los otros miembros y gozar de lãs ventajas que se derivan de la vinculación a uma comunidad estatal mayor. La organización federal se basa em la idea de que la constituición federal estabelece un compromisso entre los interesses de la unidad nacional y de la autonomia regional, creando por médio de la comprensión racional um equilíbrio duradero y beneficioso para todos los participantes $^{8}$
\end{abstract}

Assim, a repartição constitucional de competências e rendas representa a essência do pacto federativo, pois só através de sua inscrição normativa no bojo da norma fundamental fundadora do ordenamento jurídico do Estado tem-se como preservado o equilíbrio de poderes entre os componentes da Federação e a própria autonomia dos entes políticos, aspecto estrutural de uma nova organização política estatal. Vê-se, portanto, que a base jurídica do Estado Federal deve ter arrimo direto e imediato na norma máxima do ordenamento - a Constituição Federal, representada nas palavras de Loewenstein como a "aliança eterna" do pacto.

E justamente a dinâmica da partilha de competência a coloração federalista arquitetada pelo povo, ora mais centralizadora, ora regionalista, ora mais flexível. Em verdade, a medida da autonomia dos entes federativos é revelada pela divisão de matérias que lhe são próprias expressamente apontadas na Lex Fundamentalis. Deve haver um campo normativo próprio ou exclusivo dos Estados-partes, que independe de qualquer complementação de lei federal, imune assim à interferência do poder central. A mesma sorte segue a distribuição de rendas, predicado inerente à real partilha da autonomia, pois somente com renda se vivifica a

\footnotetext{
${ }^{8}$ LOEWENSTEIN, 1986, p. 356.
} 
autonomia dos entes federados - firmada no bojo da Constituição com a partilha dos tributos entre os entes políticos.

A auto-organização dos entes federados advém justamente da competência legislativa expressa no pacto constitucional, sufragada no âmbito político pela escolha dos seus governantes pelo seu próprio povo. Sua estrutura segue o modelo institucional de Estado Federal, com Executivo próprio para as competências administrativas; Legislativo para dispor sobre a competência que lhe é reservada e por fim um Judiciário para dizer o direito. Contudo, a autodeterminação dos Estados-membros da Federação não é absoluta, pois a estrutura de seu governo está submetida aos moldes do pacto federativo, de sorte que a Constituição Estadual deve seguir os princípios estruturantes da Federação, como a forma republicana, a eletividade, os direitos fundamentais do cidadão, o processo legislativo, entre outros advindos do modelo estatal da Constituição Federal, conforme a forma de governo e a dinâmica entre governantes e governados que inspira a Constituição Federal - assunto a ser explicitado em capítulo próprio.

Importante observar, pois, que no federalismo os distintos entes federados recebem poderes, atribuições e competências, em suma, sua autoridade diretamente da Constituição, independentemente de qualquer anuência dos demais entes políticos e suas autoridades. Assim, tais predicados não poderão ser ultrajados pelo legislador ordinário; se pudessem, tratar-se-ia de um Estado unitário descentralizado.

A indissolubilidade do vínculo representa a soberania da Federação, tida como poder uno, exclusivo e supremo, de forma que não se compatibiliza com a secessão dos demais entes federados. Trata-se de imperativo lógico à necessidade de se impedir a desestrutura dos componentes da Federação através de preceito constitucional explícito ou ao menos implícito. Nesse diapasão, é mister a instauração de mecanismos de segurança para assegurar a saúde da federação contra as insurgências separatistas, socorrida através da intervenção federal nos Estados membros.

O quarto requisito do federalismo é de cunho político associativo. Deveras, a própria origem do termo federação advém do latim foedus-eris, que significa aliança entre nações independentes, daí o seu impulso originalmente associativo. Assim, sempre se fez presente a necessidade de participação da vontade dos entes políticos na elaboração das normas nacionais, isto é, válidas para todo o território da Federação - eis a desconcentração do poder 
político, de envergadura muito mais profunda que a simples descentralização administrativa, típica do Estado Unitário. A estrutura federal requer a existência de múltiplos centros de poder, bem como a participação isonômica dos Estados-membros na sua representação política na Câmara Alta.

Por derradeiro, o federalismo requer a existência de um tribunal constitucional que no Brasil é papel do Supremo Tribunal Federal, que assegura a supremacia constitucional, o controle de repartição de competências e o julgamento dos conflitos entre a União e os Estados-membros ou entre esses, imprescindível para a manutenção do pacto federativo ${ }^{9}$.

Diz-se ainda característico do federalismo o aspecto unitário no plano internacional e interno, pois a Federação representa todos os entes federados pela criação de um único Estado, visto no plano internacional como uma única pessoa jurídica de Direito Internacional Público, e, por desiderato lógico, uma única nacionalidade para toda pessoa que nasce no mesmo território nacional - unidade territorial e de unidade de nacionalidade.

Carmen Lucia Rocha observa que, diante das peculiaridades de cada Estado e sua composição jurídica e política, o mundo atual não tem apenas um modelo de federalismo (ou de Estado Unitário). Tanto assim que M. Frenkel registrou a existência de mais de 20 estados federais no mundo, com ocupação territorial correspondente a 52\% da área terrestre e $40 \%$ da população mundial ${ }^{10}$.

\section{l Evolução do Federalismo e a Repartição de Competências}

Diante das profundas transformações da sociedade e do papel do Estado nos últimos séculos, sofreu o federalismo nítida evolução, perfilhada especialmente pela dinâmica na divisão das competências dos entes políticos e a correspectiva divisão de receitas.

Inicialmente a partilha de competências era singela, cabia à União legislar sobre os assuntos expressos na Constituição Federal, enquanto que ao Estados-membros caberia a legislação remanescente. Assim, se criou o federalismo dual, onde os dois centros de poder eram autônomos e iguais atuando sem interpenetrações e interferências recíprocas. Essa

\footnotetext{
${ }^{9}$ A Carta Brasileira de 1988 atribui ao Supremo Tribunal Federal competência para resolver questões constitucionais quando advenham de conflito com a própria Constituição Federal, ou lei local em face da lei federal ou quando aprecia representações para fins interventivos. Já o Superior Tribunal de Justiça é competente para uniformizar a interpretação da lei federal em âmbito nacional.

${ }^{10}$ FRENKEL apud ROCHA, Carmen Lucia A. República e Federação no Brasil: traços constitucionais da organização política brasileira. Belo Horizonte: Del Rey, 1997, p. 170.
} 
dinâmica de poder facultou um vácuo de poder significativo, pois a União não podia legislar sobre assuntos para os quais não recebera outorga constitucional ${ }^{11}$.

A concepção do federalismo clássico ou o dual federalism é baseada estritamente na chamada repartição horizontal de competências, cuja técnica de repartição de competências privativas ou reservadas é sintetizada por Manoel G. Ferreira $\mathrm{F}^{\mathbf{o}}$, baseada em separar, radicalmente, a competência dos entes federados, por meio de atribuição a cada um deles de uma 'área' própria, consistente em toda uma matéria (do geral ao particular ou específico), a ele privativa, a ele reservada, com exclusão absoluta da participação, no seu exercício, de outro ente ${ }^{12}$. Assim, no modelo norte-americano original, as competências eram repartidas através da técnica da enumeração específica ao ente central, enquanto que as remanescentes ficavam ao encargo dos Estados-membros.

O modelo do federalismo dual, baseado na repartição horizontal de competências é propício à ideologia vivenciada nos séculos XVIII e XIX até o início do século XX, cujas atribuições do Estado e o contexto social, econômico e político deram ensejo ao Estado Liberal, que limitava as competências do Estado - baseado na ideologia liberal de John Lock e Adam Smith. O federalismo dualista condicionou daí tanto o governo federal como os estaduais que tiveram suas áreas de poder rigidamente definidas, de forma a considerar inválido os atos que ultrapassassem tais limites, consoante conclui Leda R. Boechat ${ }^{13}$. Criouse, por conseqüência, o ambiente propício ao laissez faire, laissez passer, onde se instalou um "reino de não poder" até a eclosão da crise de 1929 - com a quebra da Bolsa de Nova York, ocasionado justamente em razão da ausência da regulação estatal.

A partir de então houve mudanças significativas no modelo estatal que acolheu os argumentos do economista inglês J. M. Keynes, em prol da intervenção do Estado na

\footnotetext{
${ }^{11}$ Eis o comentário original na obra $O$ Federalista: "Os poderes delegados ao governo federal pela Constituição proposta são poucos e definidos. Os que hão de ficar em mãos dos governos dos Estados são numerosos e indefinidos. Os primeiros empregar-se-ão principalmente com relação a objetivos externos, como a guerra, a paz, as negociações e o comércio estrangeiro; e é com este último que o poder tributário se relacionará principalmente. Os poderes reservados aos Estados estender-se-ão a todos os objetivos que no curso normal das coisas interesse às vidas, liberdades e propriedades do povo, e à ordem interna, ao progresso e à prosperidade dos Estados." Apud VASQUES, Denise. Competências Legislativas Concorrentes: prática legislativa da União e dos EstadosMembros e jurisprudência do Supremo Tribunal Federal, Dissertação de Mestrado FADUSP, 2007, p. 22.

12 FERREIRA FILHO, Manoel G. O Estado Federal brasileiro à luz da Constituição de 1988. Revista da Faculdade de Direito da Universidade de São Paulo, v. 86, 1991.

${ }^{13}$ BOECHAT apud RODRIGUES, Nina T. D. Novos Rumos para o Federalismo: contribuições para a sua melhoria. Tese de Doutorado. Faculdade de Direito da USP, São Paulo, 2007, p. 64.
} 
economia para implantação de obras públicas e assistências, a fim de fomentar a economia, o chamado New Deal, que ensejou um novo modelo de federalismo, baseado na cooperação dos entes federados para implantar programas e planejamento comum apto a resgatar o capitalismo.

O New Deal abriu os flancos para o chamado federalismo cooperativo, eis que ampliou indiretamente as competências federais ao legitimar a atuação da União em áreas até então intocadas pela potestade estatal, como a economia. Tal orientação foi sufragada pela Suprema Corte norte-americana, que amparou a doutrina dos poderes implícitos, apta a conferir competência constitucional ao poder central para implementar políticas públicas. Relativizouse, assim, o chavão de que os poderes não delegados à União e nem proibidos aos Estados devem ser considerados reservados aos Estados, ao afirmar que se cuidava de truísmo sem importância prática, conforme preleciona Dalmo de Abreu Dallari ${ }^{14}$.

Positivamente, foi o texto da Constituição de Weimar de 1919 (Alemanha) que inaugurou a técnica de repartição concorrente de competências, onde a mesma matéria é atribuída concorrentemente a entes federativos diversos em diferentes níveis: a um atribui-se o estabelecimento de normas gerais; a outro, normas particulares ou específicas.

Assistiu-se, assim, a uma expressiva mudança no perfil de atuação do ente central, acentuando-se as forças centrípetas, isto é, de centralização do poder nas mãos do ente central. Tal fenômeno é mundial, ocasionado sobretudo em razão das mudanças de perspectivas da atuação estatal - outrora liberal, que passa a assumir característica marcantemente intervencionista, ditada por razões políticas (proeminência do Presidente da República) e econômicas - o que acarretou uma mudança de perfil do próprio federalismo.

O constitucionalista norte-americano Ellis Kats sumariza essa mesma assertiva ao observar que afora algumas questões, atualmente não há maiores limitações constitucionais ao governo federal:

...constitucionalmente, a concepção do governo federal deixou de ser aquela de um governo limitado e passou a ser aquela de um governo geral, com ampla autoridade para promulgar qualquer lei que acredite ser do interesse dos cidadãos norteamericanos. Isso não significa sugerir que o governo nacional use sempre sua autoridade. Tal como todos os governos, o governo nacional norte-americano continua limitado por fatores econômicos e políticos ${ }^{15}$

\footnotetext{
${ }^{14}$ DALLARI, Dalmo de Abreu. O Estado Federal. São Paulo: Atica, 1986, p. 46.

${ }^{15}$ KATS apud ALMEIDA, Fernanda Dias Menezes de. Competências na Constituição de 1988. $2^{\mathrm{a}}$ ed., São Paulo: Atlas, 2000, p. 37.
} 
José Afonso da Silva pontua o abandono do federalismo dualista diante da sua própria evolução e da ampliação das tarefas do Estado contemporâneo, onde se tem acolhido composições mais complexas de distribuição de competências, como a distribuição de áreas comuns em que se prevêem atuações paralelas e setores concorrentes em que a competência para estabelecer políticas gerais cabe à União, enquanto se defere aos Estados a competência suplementar, como ocorre na Alemanha e no Brasil, na busca de reconstruir o sistema federativo segundo critérios de equilíbrio ${ }^{16}$.

Atualmente se procura nas diferentes partes do globo terrestre ${ }^{17}$ a solução para se atingir um federalismo de equilíbrio, satisfatório para equalizar as forças dos entes federados na dinâmica do pacto federativo. Graças à instituição da competência concorrente e da participação simultânea dos entes federados na repartição de receitas tributárias, corroborado a mecanismos que atenuam as disparidades regionais entre as unidades federadas - mediante incentivos fiscais, criação de zonas de desenvolvimento e partilha de fundos públicos -, tem-se encontrado algum equilíbrio nos poderes entre os entes federados.

Certamente o equilíbrio almejado também finca terreno no âmbito da partilha de receitas, eis que o pacto federativo representa um conjunto de complexas alianças soldadas em grande parte por meio de fundos públicos. E nesse sentido que Rui A. Affonso observa que o compartilhamento de fundos públicos é de crucial importância no caso de países com enormes heterogeneidades estruturais, de forma que propõe significativas transferências de recursos públicos para regiões com desigualdade econômica e assimetrias sociais, já que o mercado é incapaz de soldar per se a aliança federativa ${ }^{18}$.

Croisat pontua que o federalismo de equilíbrio é o que tem prevalecido no Direito Constitucional contemporâneo, pois confere, nas suas palavras, à une possible conciliation entre intégration et autonomie, unité et diversité em response aux aspiration humaines simultanées pour la l'indépendance et la solidarité ${ }^{19}$. Essa é a ideia que prevalece no Direito Constitucional pátrio, pois o princípio federativo (em consonância com os objetivos da Carta

\footnotetext{
${ }^{16}$ SILVA, José Afonso da. Curso de Direito Constitucional Positivo. $29^{\circ}$ Ed. São Paulo: Malheiros, 2006, p. $477-$ 479.

${ }^{17} \mathrm{O}$ mundo assistiu a outras técnicas de compartilhamento de competências, das quais merece menção as Cartas Políticas alemã de 1919, da Áustria de 1955 e da Índia de 1950 (enumera os poderes expressos tanto para União como para os Estados na tentativa de excluir os poderes reservados) e o Canadá (cuja distribuição de competência explicita os do Estado Membro e deixa os remanescentes para União).

${ }^{18}$ AFFONSO, Rui. A Federação no Brasil: Impasses e Perspectivas. Revista A Federação em Perspectiva: ensaios selecionados. Fundap, 1995, p. 56-75.

${ }^{19}$ CROISAIT apud ROCHA, 1997, p. 173.
} 
Republicana de 1988) busca equacionar as disparidades entre os entes federados justamente para atingir a conciliação supra citada entre a integração e autonomia, unidade e diversidade.

O constitucionalista norte-americano Daniel Eleazar leciona que o objetivo do sistema federativo é a consecução e a harmônica manutenção da unidade e da diversidade entre as partes federadas, as quais não devem ser consideradas como opostas. Basicamente, a federação pretende unidade na diversidade, procurando unir entidades heterogêneas em torno de um conjunto de regras comuns, conferindo-lhe certa homogeneidade. Mas, ao mesmo tempo, pretende que essa unidade preserve a diferenciação entre os elementos componentes da federação, respeitando a identidade cultural e política de cada $u^{20}$.

Eis o trunfo e ao mesmo tempo o desafio do federalismo, a manutenção equilibrada da unidade central, preservando-se a autonomia das entidades políticas componentes da Federação.

Interessante, ainda, observar que o federalismo atualmente tem assumido nova feição, antes notadamente de descentralização política-administrativa, mas que paulatinamente se assume como instrumento de garantia da democracia participativa, pois, como é sabido, a participação da cidadania (imersa também nos interesses sociais da sociedade civil) é maior junto aos poderes locais ${ }^{21}$.

A peculiaridade nacional inicia-se já pela formação original da Federação brasileira, que, ao revés da norte-americana, surgiu da segregação de um Estado Unitário, o Império, para uma Federação, consistente num movimento de acentuada descentralização política e territorial impulsionada pelo exemplo norte-americano. A Federação nacional seguiu os seus passos e sua ideologia, inicialmente sedimentada no dual federalism, onde a União e os Estados membros legislavam cada qual na sua seara de competências de modo estanque e sem maior política de integração.

A evolução do nosso federalismo acompanhou a mesma tônica do paradigma americano, impulsionado inicialmente pela expansão da força centrífuga, isto é, descentralizadora, e paulatinamente foi cedendo à força centrípeta - por impulsos semelhantes ao exemplo americano, como o movimento desenvolvimentista - até seu apogeu, advindo pelo federalismo de integração, onde a União planejava e controlava a atuação dos Estados no

\footnotetext{
${ }^{20}$ ELEAZAR apud DALLARI, 1986, p. 49-50.

${ }^{21}$ LOBO, Paulo Luiz Neto. Competência legislativa concorrente dos Estados-membros na Constituição de 1988. Revista de Informação Legislativa, nº 101, Brasília, 1989, p. 87-104.
} 
regime constitucional de 67/69. Nesse período vivenciou-se verdadeiro estrangulamento da autonomia dos Estados-membros, intensificada pela parca divisão tributária em detrimento dos poderes locais, sob a filosofia do princípio da supremacia federal ${ }^{22}$.

No regime constitucional de 1967 as diretrizes de "segurança nacional" legitimaram o avanço do poder central através da chamada hipertrofia do Poder Executivo, em detrimento da autonomia dos demais entes federados, cujos Governadores eram escolhidos direta e pessoalmente pelo Presidente da República (circunstância que minou o autogoverno dos Estados-membros).

Justamente como um movimento pendular, o constituinte de 1988 buscou novos rumos para o federalismo nacional. A Constituição de 1988 buscou maior descentralização aos entes federados. Eis a temática do constituinte, uma federação engajada constitucionalmente sob o pálio da autonomia aos entes-membros, esses coordenados pela União, mas não subordinados hierarquicamente - em conformidade com a tendência mundial do federalismo ${ }^{23}$.

Essa constatação pode ser aferida diretamente dos trabalhos dos constituintes, firmada no próprio relatório do Anteprojeto da Comissão da Organização do Estado, onde se reconhece a busca para maior descentralização; contudo não num movimento radical, mas gradativo/equilibrado e coordenado pela ação conjunta dos entes federados, através da competência concorrente:

Não obstante a procedência dos argumentos e a legitimidade da pretensão dos Estados e dos Municípios, é preciso ter em vista que a centralização constitui um processo histórico ao longo do tempo. Esta realidade não pode ser nem escamoteada, nem desconsiderada na avaliação da estratégia de recuperação das autonomias periféricas.

Pretende-se dizer, com isso, que da mesma forma como se processou o federalismo centralizado, é de bom senso que a mudança do modelo obedeça a mecanismos que possam viabilizar uma descentralização federativa gradual, no processo de reconquista das autonomias subtraídas.

Não é crível que a mudança instantânea da centralização à descentralização federativa corresponda, na prática, ao automatismo que se imagina. Não se desconheça que a União agigantou-se demasiadamente e essa avultação não pode ser achatada de uma hora para outra sem os riscos inerentes a qualquer processo traumático, os quais, no caso, poderiam confluir à própria inviabilidade de mudança.

\footnotetext{
${ }^{22}$ Sobre o tema, Cf. ALMEIDA, Fernanda Dias Menezes de. Competências na Constituição de 1988. 4. ed. São Paulo: Atlas, 2007.
}

2000.

${ }^{23}$ LOBO, 1989. 
Com a mesma percepção, certamente, a Comissão Provisória de Estudos Constitucionais sugere, no seu Anteprojeto, a criação de uma esfera comum de competência material e legislativa como instrumento adequado a propiciar a alteração gradual do modelo.

O Relator, reconhecendo que o referido Anteprojeto consubstancia um texto seguro e bastante satisfatório no capítulo da Organização do Estado, toma-o como base de sua proposta. ${ }^{24}$

Contudo, na prática, o intuito descentralizador do constituinte não se mostra satisfatório, de um lado, em razão do expressivo exercício legislativo da União, inclusive no âmbito tributário (baseado no alargamento da tributação das contribuições federais); de outro lado, em razão de uma atuação tímida do legislador estadual, o que tem contribuído para prevalência de forças centrípetas (centralizadoras) no federalismo pátrio. Tal assertiva é corroborada pelo posicionamento jurídico institucional do Supremo Tribunal Federal, instituição que molda a interação de forças legislativas no federalismo nacional, conforme exame a ser realizado nos próximos capítulos.

Enfim, o perfil do federalismo brasileiro volta-se para um federalismo de equilíbrio, ainda em processo de amadurecimento, cuja interação de forças políticas, jurídicas e tributárias ainda está se sedimentando no cenário institucional mediante o exercício legislativo dos entes federados, o avanço da doutrina e a jurisprudência do Supremo Tribunal Federal ${ }^{25}$.

Nesse mesmo sentido é o estudo de Maria Hermínia Tavares de Almeida, ao observar que o nosso federalismo tem trabalhado com a centralização e descentralização concomitantemente (e não de forma excludente como se imagina), de forma que se assiste à passagem de uma forma extrema de federalismo centralizado, construída sob o regime autoritário, para alguma forma de federalismo cooperativo (ou de equilíbrio, termos tidos como equivalentes), cujas feições ainda estão se definindo, pois envolve o redesenho das funções do governo federal ${ }^{26}$, bem como a participação efetiva dos demais entes federados no uso de suas prerrogativas legislativas e atribuições administrativas.

\footnotetext{
${ }^{24}$ ALMEIDA, 2007, p. 65-66.

${ }^{25}$ Opinião semelhante é compactuada por Rui de Britto A. Affonso ao ponderar que, embora descentralizada, a nossa Federação ainda não possui um novo perfil e modus operandi definidos, persistindo diversas lacunas ou vazios nas fronteiras das divisões de competências entre as diversas esferas de governo. AFFONSO, 1995, p. 5675.

${ }^{26}$ ALMEIDA, Maria Hermínia Tavares de. Federalismo e Políticas Sociais. Revista Brasileira de Ciências Sociais. nº 28, junho de 1995, p. 88-108. Prossegue a autora no estudo das competências materiais de habitação, educação, saúde, e de assistência social onde constata que em nenhum dos casos são criadas condições favoráveis à definição de atribuições e de formatos organizacionais mais adequados a um modelo estatal federativo e
} 
descentralizado, que, bem ou mal, vem se gestando há quase uma década. Da mesma forma, estados e municípios não são capazes de definir com clareza seus papéis quando a lei estabeleceu competências concorrentes e resistem, de forma crescente, a assumir funções que o novo modelo lhes atribui, em que pese a transferência de recursos promovida pela Constituição de 88. (...) Nessas circunstâncias, o conflito entre os níveis de governo tende a se acirrar e assumir distintas formas, todas com efeitos paralisantes sobre a definição do pacto federativo em bases cooperativas. (...) Conclui que a reordenação das relações intergovernamentais nas áreas sociais é necessariamente um processo de longa duração e a diferentes velocidades nos diversos estados e regiões. Mesmo que venha a ser orientado por políticas nacionais coerentes, jamais resultará em distribuição uniforme de competências e funções em todo o território nacional. Em outros termos, a participação relativa de estados e municípios - e de agências federais - no financiamento, decisão e gestão de cada uma das políticas sociais variará inevitavelmente pelo país afora. Por exemplo, em alguns estados a educação básica será integralmente de responsabilidade municipal, em outros apenas parcialmente e em outros ainda continuará de competência estadual. O mesmo ocorre com a saúde e assim por diante. 



\section{Capítulo II: A Repartição de Competências na CF de 1988 2.l O Modelo de Repartição de competências adotado}

O atual modelo constitucional encampou modelo federalista arrojado, de três níveis - a União; os Estados-membros e o Distrito Federal; e os Municípios. O sistema é baseado num complexo sistema de repartição de competências materiais, legislativas e tributárias, congregando critérios de ótica horizontal e vertical para a partilha de competências; contemplou ainda competências comuns e hipóteses de delegação de competências da União para os Estados membros, com fundamento ideológico no federalismo de equilíbrio, conforme expressa o art. 22, parágrafo único da $\mathrm{CF}$.

A Constituição Cidadã adotou no complexo de distribuição de competências a busca pelo equilíbrio federativo ${ }^{27}$. Recompôs-se, dessa forma, a arquitetura dos poderes entre a União e os demais entes federados, corroborada pela instituição de mecanismos de correção das disparidades econômicas e sociais das regiões, a redistribuição de rendas entre os entes federados de alguns impostos (análogo à divisão vertical de competências), o planejamento regional de investimento e incentivos fiscais. Vivencia-se, assim, o federalismo de equilíbrio.

A peculiaridade mais significativa do federalismo brasileiro foi a tripartição dos entes federados, diante da elevação dos Municípios a membro integrante da Federação Brasileira, nos termos do artigo $1^{\circ}$ e 18 da CF. O modelo constituinte atribui ao Município competências próprias, autonomia política e tributária, bem como capacidade de auto-organização, por meio de lei orgânica municipal, e autogoverno através de Prefeitos eleitos diretamente pelo povo; contudo não atribui aos Municípios representação no Senado Federal. Eis a inovação nacional: o Município faz parte do concerto nacional, orquestrado pela essência federativa, a unicidade nacional em convivência com a autonomia local, onde o povo agora pode decidir sobre os rumos da política municipal nos interesses de suas peculiaridades.

Veja-se, pois, a técnica utilizada pelo constituinte para repartição das competências aos entes federativos. A Constituição definiu primeiramente as competências materiais/administrativas da União, art. 21, posteriormente arrolou, em sintonia com as atribuições administrativas, as suas competências legislativas privativas (art. 22). Aos Estados foi deferida a competência remanescente não enumerada (art. $25, \S 1^{\circ}$ ). Por sua vez, os

\footnotetext{
${ }^{27}$ SILVA, José Afonso. Curso de Direito Constitucional Positivo. $2^{\circ}$ Ed. São Paulo: Malheiros, 1984, p. 479.
} 
Municípios receberam poderes estabelecidos indicativamente quando presente o interesse local, tanto para legislar como administrar, bem como suplementar a legislação federal e estadual no que couber.

A competência legislativa concorrente finca-se no art. 24 da CF, onde se positiva a repartição vertical de competências, cabendo as normas gerais à União e a legislação suplementar aos Estados. Há, ainda, as competências administrativas comuns, donde decorre a competência legislativa imprópria ou indireta aos entes federados (art. 23 da CF), conforme se verá adiante. Eis a repartição vertical de competências na esteira do modelo alemão, inspiração do constituinte, com alternativas criativas para se alcançar o balanceamento necessário para um federalismo de equilíbrio e a integração legislativa dos entes federados nas diferentes searas que atuam conjuntamente, como a delegação de competências legislativas da União aos Estados.

Dada a prerrogativa conferida aos Municípios para suplementar a legislação federal e estadual no couber, isto é, quando presente interesse municipal, também há a participação municipal nos contornos da competência concorrente.

Esquematicamente temos:

Competências Legislativas Privativas da União: art. 22 da CF;

Competências Administrativas da União = competências legislativas indiretas: art. 21;

Competências Legislativas dos Estados: art. 25, $\S^{\circ}$ da $\mathrm{CF}$ (competências remanescentes);

Competências Legislativas Privativas dos Municípios: art. 30, I, da CF;

Competências Legislativas Concorrentes dos entes federados: art. 24 e 30, II da CF.

Competências Administrativas Comuns de todos os entes federados = competências legislativas comuns indiretas: art. $23 \mathrm{da} \mathrm{CF}$.

$\mathrm{Na}$ seara tributária, o constituinte teve o zelo de dividir a competência de cada ente federado para assim garantir autonomia de renda aos entes federados, premissa primordial para o desempenho das tarefas que lhe são próprias. O constituinte formatou verdadeiro subsistema constitucional em Título constitucional específico - arts. 145 a 169 - cujo figurino é primordialmente de competência exclusiva a cada ente federado para instituir os tributos que lhe são próprios. Deferiu à União ainda a competência residual para criação de novos tributos. Por razões de limitação do tema, o estudo fará apenas incursões sobre o Direito Tributário na 
divisão das competências legislativas, sem se aprofundar sobre o tema - justamente por se cuidar matéria afeita ao próprio Direito Tributário.

A Constituição Federal estabelece ainda a repartição das receitas dos tributos, vale dizer, como se distribuem entre os entes federados as receitas obtidas com o exercício da competência tributária. Há também traços de uma divisão vertical de repartição de impostos, de forma que essa receita seja redistribuída entre federados distintos diretamente ou por meio de sistema de fundos. Atenua-se, assim, disparidades econômicas entre entes federados mais pujantes economicamente que outros num país tão assimétrico como o Brasil.

Rui de Britto Affonso traça o quadro comparativo da divisão do bolo tributário antes e pós-Constituição de 1988, onde denota que os principais beneficiários pela nova partilha do bolo tributário são os Municípios, pois ampliaram sua participação na receita disponível (considerada as transferências governamentais) de 9\% em 1980 para 16\% em 1993, ao passo que a receita própria passou de $3 \%$ para $5 \%$, o que evidencia que sua maior participação advém das transferências federais. Já os Estados passaram de $22 \%$ para $26 \%$ na partilha do bolo tributário quanto à receita disponível entre 1980 e 1993. Por sua vez, a receita própria da União passou de $75 \%$ em 1980 para 68\% em 1993 e sua receita disponível nesse mesmo período reduziu de $69 \%$ para $58 \%{ }^{28}$.

Já no ano de 2007 a receita tributária foi partilhada da seguinte forma (sem contar as transferências tributárias): União - 69,83\%; Estados - 19,28\%; Municípios - 10,89\%, estatísticas da receita arrecadada, segundo o IBGE.

\subsection{A Competência Legislativa Privativa da União}

De início insta esclarecer que a União é um ente federado tal como os Estadosmembros, os Municípios e o Distrito Federal, e não se confunde com a República Federativa do Brasil. Essa divisão torna-se mais clara quando a União legisla para seus servidores ou para sua polícia (federal). Contudo, a União também age em nome da Federação quando mantém relações com o Estados estrangeiros, assegura a defesa nacional ou decreta estado de sítio e a intervenção federal (art. 21, I, II e IV da CF). Justamente por essa dupla atribuição, Michel Temer observa que a União é uma figura de duas faces, que tanto age em nome próprio como

\footnotetext{
${ }^{28}$ Fonte: A Federação no Brasil: Impasses e Perspectivas. Revista A Federação em Perspectiva: ensaios selecionados. p. 56-75. Fundap. Fonte elaborada a partir de dados do DECNA/IBGE e IBRE/FGV.
} 
em nome da Federação. Ora se manifesta por si, como pessoa jurídica de capacidade política, ora em nome do Estado Federal ${ }^{29}$.

Daí o sentido de dizer que as leis federais alcançam somente a União (como quando legisla para seus servidores), ao passo que as leis nacionais alcançam toda a Federação (quando legisla em nome da Federação). Frise-se, pois, que quanto às normas firmadas pela União, a divisão entre normas ditas nacionais ou federais tem por base não o critério territorial de validade, mas sim o critério pessoal de validade da norma, consoante preconiza Hans Kelsen $^{30}$, ao pontuar que as normas provindas da União, embora tenham [ou possam ter] todas a mesma esfera territorial de validade, tendem a diferir quanto às suas esferas pessoais de validade. As normas nacionais apresentam validade pessoal para todos os entes federados; já as normas tidas como federais, vinculam somente a União, geralmente voltadas para seu corpo administrativo, como seus servidores ou sua própria regulação administrativa.

Esclareça-se, ainda, que a federação é uma forma de organização interna do Estado, de sorte que os entes federados têm personalidade jurídica de direito público interno, ao passo que somente a República Federativa do Brasil é pessoa de direito internacional, soberana, isto é, instância única de poder e representatividade no âmbito externo. Por conseqüência só há que se falar em uma única nacionalidade para País - pois o Estado soberano é um só, a República Federativa do Brasil; os entes federados são entes autônomos, componentes da Federação.

Como já frisado, a repartição de competências é perfilhada diretamente na Constituição da República, tipologicamente situada na organização do Estado, Título III, cujo Capítulo II trata da União Federal particularizada em 29 incisos do art. 22, que trata das competências legislativas privativas da União. Por sua vez, o parágrafo único do art. 22 autoriza, mediante positivação de lei complementar, que os Estados legislem sobre questão específica das matérias apontadas nos incisos arrolados no art. 22.

Competência legiferante é a atribuição constitucional do poder de legislar sobre determinado rol de assuntos a um ente federado. O termo competência aqui empregado equipara-se à aptidão de capacidade, isto é, atribuições institucionais atribuídas ao ente

\footnotetext{
${ }^{29}$ TEMER, Michel. Elementos de direito constitucional, 10. Ed. São Paulo: Malheiros Ed., 1993, p. 77. Também nesse sentido, Cf. ARAÚJO; NUNES JÚNIOR, 2009, p. 281.

${ }^{30}$ KELSEN, Hans. Teoria Geral do Direito e do Estado. 2 ed. Tradução de Luis Recaséns Siches e Justino de Azcárate. Barcelona: Bosch, 1934, p. 435.
} 
político como manifestação de sua autonomia; e no âmbito de competência federal, expressão de sua soberania.

A repartição constitucional das competências legislativas é a pedra angular do federalismo, pois concretiza a descentralização política e administrativa dos entes políticos e garante, assim, maior segurança à democracia - dada a existência de múltiplos centros de poder político e não apenas administrativo, o que assegura melhor participação do povo na tomada de decisões e na fiscalização da res publica, marcos da democracia. Avulta-se, pois, a relevância do tema tanto para a estrutura do federalismo como para o regime democrático.

Importante ainda registrar que não é só a partilha constitucional de competências que condiciona o federalismo de equilíbrio e a real autonomia dos entes federados, mas também a sua efetiva utilização, bem como sua aplicação e interpretação pelos tribunais, como se verá na segunda parte dessa Dissertação.

Do mesmo modo que a competência executiva (ou administrativa), a competência legislativa descrita no artigo 22, em seus 29 incisos, não esgota a competência legislativa da União. A rigor, toda matéria de competência da União é suscetível de regulamentação mediante lei, ressalvadas as disposições próprias do Congresso Nacional, arts. 49, 51 e 52 . O próprio art. 48 descreve outras competências legislativas, baseadas nas atribuições do Congresso Nacional para disciplinar o rol descritivo de incumbência federal. Constam, ainda, outros preceitos esparsos da Constituição Federal que requerem lei federal para disciplinar prerrogativas e atribuições da União Federal.

Enquanto o artigo 22 disciplina a competência legislativa privativa da União Federal através da técnica da divisão horizontal de competência horizontal (suscetível de delegação expressa por lei complementar), o artigo 24 consubstancia as competências concorrentes.

A competência legislativa da União concentra-se basicamente sobre quatro planos, a saber:

a) (quando age em nome da Federação) nas tarefas da República Federativa do Brasil que guarnecem a unidade do País no trato com os demais Estados soberanos e entre os entes políticos, como as normas gerais de direito tributário - a legislação sobre nacionalidade, cidadania e naturalização (XIII); emigração e imigração, entrada e expulsão de estrangeiros $(X V)$, requisições civis e militares (III), defesa do território nacional (XXVIII); comércio exterior e interestadual (VIII); 
b) nas áreas de atuação estratégica para a integração nacional pelo direito, pela cultura e pela ordem social, assuntos que integram a sociedade brasileira através de regras homogêneas em todo o território nacional - como o direito civil, comercial, penal, processual, eleitoral, agrário, marítimo, aeronáutico, espacial e do trabalho (I); desapropriação (II); as bases da educação nacional (XXIV); a organização do sistema nacional de emprego e condições para o exercício de profissões (XVI); trânsito e transporte (XI) e a seguridade social (XXIII); registros públicos (XXV); normas gerais de licitação e contratação, em todas as modalidades, para as administrações públicas diretas, autárquicas e fundacionais da União, Estados, Distrito Federal e Municípios, obedecido o disposto no art. 37, XXI, e para as empresas públicas e sociedades de economia mista, nos termos do art. $173, \S 1^{o}$, III (XXVII); propaganda comercial (XXIX);

c) na seara da política econômica e financeira nacional, própria do regime capitalista extensivo para todos os entes federados: como o sistema monetário nacional (VI), a política de crédito, câmbio, seguros e transferência de valores (VII); sistemas de poupança, captação e garantia da poupança popular, bem como a definição das áreas de atuação estatal nos casos de imperativos de segurança nacional ou de relevante interesse público (art. 173); estabelecer as diretrizes e bases do planejamento do desenvolvimento nacional (art. 174, $\$ 1^{\circ}$ ).

d) competências remanescentes, firmadas no art. 22, decorrentes de suas atribuições materiais e de seus bens, como a legislação de águas, energia, informática, telecomunicações e radiofusão (IV); o serviço postal (V); jazidas, minas, outros recursos minerais e metalurgia (XII); organização judiciária, do Ministério Público e da Defensoria Pública do Distrito Federal e dos Territórios, bem como organização administrativa destes (XVII); sistema estatístico, sistema cartográfico e de geologia nacionais (XVIII); normas gerais de organização, efetivos, material bélico, garantias, convocação e mobilização das polícias militares e corpos de bombeiros militares (XXI); competência da polícia federal e das polícias rodoviárias e ferroviárias federais (XXII); atividades nucleares de qualquer natureza (XXVI).

Em que pese a topologia de sua classificação como competência legislativa privativa, alguns dos incisos supra merecem ser classificados como de competência concorrente, fiel à semântica do termo e sua interpretação sistemática, como os campos normativos voltados às diretrizes gerais da União, apresentados nos incisos IX, XXI, XVI e XXVII, quais sejam, diretrizes da política nacional de transportes; normas gerais de organização das polícias 
militares; diretrizes e bases da educação nacional; e normas gerais de licitação e contratação na Administração Pública em geral - justamente por demandarem normas de caráter geral, de forma que não se proíbe a complementação da legislação pelos Estados.

De um lado, tem-se como imperativo o caráter nacional das normas substanciais até como condição de integração nacional através de regras homogêneas em todo o território nacional, como o direito penal, civil, comercial, os registros públicos, os serviços notariais (art. 236 da CF), a seguridade social e o direito alfandegário.

De outra banda, dada a extensão e profundidade do rol legislativo da União Federal, assiste-se no cenário nacional o que ocorre mundialmente, a universalidade da tendência fortificante da União no federalismo contemporâneo (impelida pelos fenômenos mundiais de integração que exigem presença firme e coordenada do ente central).

Lastreada nessa crítica, algumas competências poderiam ser compartilhadas (competência concorrente) e até mesmo transferidas para os demais entes federativos: como o direito processual, diante da peculiaridade de demandas jurídicas em cada Estado, onde a União poderia lançar os preceitos diretrizes cogentes e os Estados regras peculiares, frente à sua conjuntura geográfica e social ${ }^{31}$; o planejamento nacional é extremamente centralizado nas mãos da União. Salutar seria a participação dos Estados, dos organismos regionais e municipais na elaboração das bases do planejamento, conforme originalmente constava no anteprojeto de Comissão Afonso Arinos (art. 72, XIII); da mesma forma, o direito agrário poderia ser regrado pelos Estados-membros de forma concorrente com a União, diante da patente diversidade geográfica e biológica no País, de forma que cada Estado teria melhores condições de regulamentar seus interesses e reivindicações e, assim, otimizar seus potenciais agrários.

Enfim, a crítica que se tece é a excessiva pormenorização de atribuições de competências à União em matérias que poderiam ser conferidas aos Estados, quer no texto constitucional, quer na legislação ordinária, quer ainda na interpretação das competências e ao federalismo pelos Tribunais, em especial pelo Supremo Tribunal Federal, último intérprete do direito constitucional.

\footnotetext{
${ }^{31}$ Pois a prática jurídica tem mostrado a heterogenia da realidade brasileira quanto a tramitação forense, cuja peculiaridade mais interessante é a intimação do jurisdicionado nos Estados do Norte, muitas vezes ocorrida de barco, o que corrobora para a flexibilização das normas processuais em prol dessa diversidade geográfica e cultural dos diversos Estados brasileiros - peculiaridade do federalismo.
} 
Em outros termos, prega-se justamente a manutenção da regra clássica do federalismo, registrada por Celso Bastos como a regra de ouro da federação, qual seja, nada será exercido por um poder de nível superior desde que possa ser cumprido pelo inferior ${ }^{32}$.

Daí a crítica lançada pelos juristas, que pregam a menor abrangência da proeminência da União nas atribuições de competências em geral, sobretudo quanto às competências legislativas privativas, como no caso do sistema de consórcios e sorteios; de planejar e promover a defesa permanente contra as calamidades públicas; de executar a inspeção no trabalho, as quais poderiam ser compartilhadas com os Estados-membros.

Oportuno observar que já tramita proposta de Emenda Constitucional para o fim de alargar atribuição das Assembléias Legislativas dos Estados, através da ampliação das competências concorrentes em detrimento das competências privativas da União Federal, especialmente para as matérias referentes a trânsito e transporte, direito agrário, diretrizes e bases da educação, propaganda comercial, licitação e matéria processual ${ }^{33}$. Esclarece a reportagem de Silvia Amorim que o texto já fora aprovado pelas Assembléias de MG, PB, ES e RR.

Ives Gandra Martins endossa esse posicionamento nos seguintes termos ${ }^{34}$ :

\begin{abstract}
Uma das maiores críticas dos constitucionalistas ao atual texto da Lei Maior é sua expressiva pormenorização, com que parcela substancial de dispositivos poder ser de legislação ordinária. (...) Consórcios e sorteios são matérias de relevância menor nas atribuições dos entes federativos, motivo pelo qual se poderia, perfeitamente, permitir que Estados e Municípios cuidassem, em suas esferas de atuação, de regular matéria. E nem por isso creio que haveria discrepância de monta entre as legislações de cada ente federativo. A não-privatização da competência, hoje, em mãos da União representaria, por outro lado, um respeito necessário à autonomia federativa. O argumento de que os sorteios e consórcios poderiam gerar conflitos nas áreas de atuação de cada ente federativo em relação aos cidadãos, que teriam que conviver com legislação díspar de cada um deles, não resiste à observação de que o consorciado se obriga à regra do plano a que adere, conhecendo inteiramente seus direitos e deveres.
\end{abstract}

\footnotetext{
${ }^{32}$ BASTOS, Celso Ribeiro; MARTINS, Ives Gandra. Curso de direito constitucional. $11^{\circ}$ ed. São Paulo: Saraiva, 1989.

${ }^{33}$ Conforme notícia divulgada no Jornal O Estado de São Paulo, em reportagem datada do dia 01.06.2009, p. A4, de Silvia Amorim, a proposta de Emenda Constitucional já fora aprovado pelas Assembléias de MG, PB, ES e RR. Interessante notar que se cuida de iniciativa pioneira baseada no art. 60, III, da CF, mediante proposta de mais da metade das Assembléias Legislativas.

${ }^{34}$ BASTOS, Celso Ribeiro; MARTINS, Ives Gandra. Comentários à Constituição do Brasil. São Paulo: Saraiva, 1993, v. 3, p. 321-323.
} 
Por sua vez, o parágrafo único do artigo 22 da CF faculta a delegação das competências legislativas da União aos Estados, através de lei complementar que fixará os limites materiais e formais específicos à delegação estadual, autêntico mecanismo de equilíbrio federativo. Contudo, na prática, infelizmente não se tem notícia de tal delegação, passados mais de vinte anos da promulgação da Constituição.

A doutrina é dividida quanto à necessidade de delegação uniforme para todos os Estados ou delegação diferenciada entre os Estados, quando presentes razões fáticas para tanto. De um lado, alguns pregam a busca de correções das assimetrias de fato, o que autoriza a delegação a somente um ou alguns dos entes federativos, pois a delegação é baseada, por natureza, em critérios políticos discricionários ao talante do legislador federal, frente às razões fáticas sempre díspares nos entes políticos. De outro lado, remanesce a necessidade de proteção ao princípio constitucional de tratamento igualitário entre os Estados, o que obriga a delegação legislativa de modo uniforme.

As críticas ora lançadas no cenário nacional também repercutem internacionalmente, quanto ao papel da injusta ${ }^{35}$ proeminência da União Federal no jogo das competências legislativas. É justamente nesse sentido o mote da Reforma Constitucional Alemã firmada no ano de $2006^{36}$, que trouxe inéditas regras de compartilhamento de competências entre os entes federados, resultando no expressivo incremento das competências concorrentes, como adiante será pontuado.

Em outros termos, a tendência centrípeta deve-se limitar aos preceitos fundantes do federalismo, justamente para assegurar faixa de autonomia indevassável aos demais entes políticos e, assim, firmar mecanismos que impeçam a exacerbada e desconcertante hegemonia do ente central sobre os demais entes políticos.

Enfim, o que se deve ter como tônica para equacionar os princípios estruturantes, ou as normas de integração nacional entre os entes federados, são os valores estampados na

\footnotetext{
${ }^{35}$ Nesse sentido leciona B. Tag Drucksache apud CRUZ, Rafael Naranjo de la. La reforma Del sistema de atribuicion de competências en La Ley Fundamental. Revista de Derecho Constitucional Europeu n ${ }^{\circ}$ 6. Jul./dez. de 2006, p. 125-160: "La motivación que acompaña la iniciativa de la reforma pone de manifesto cómo com el transcurso del tiempo han retrocedido las competencias de los Länder, en parte por causa de la creción de nuevas competencias para la Federacion a través del instrumento de la reforma constitucional, pero sobre todo, por el uso exhaustivo que de manera casi permanente ha realizado el legislador federal de sus competencias em materia de legislación concurrente y por la frecuente adopción em el caso de la legislación marco de normas de detalle y de normas inmediatamente eficaces, possibilidades previstas inicialmente em el texto constitucional com carácter excepcional.

${ }^{36}$ Cf. <http://pt.euronews.net/2006/06/30/reforma-do-federalismo-aprovada-pelo-bundestag/>.
} 
Constituição da República, próprios da República, do regime representativo - os direitos políticos e a responsabilidade política que extravasam o amálgama comum para todos os entes políticos e, como tal, de observância obrigatória - sujeito até mesmo à intervenção sobre o ente federado se desrespeitado tal mandamento, ex vi o art. 34, VII, a, da Constituição de $1988^{37}$. E, nesses estreitos limites, é que se pode falar em regras de simetria constitucional, como apontaremos na seção seguinte - justamente para preservar o mínimo de coesão às instituições republicanas do Estado Federal e manter a autonomia dos demais entes federados.

\subsection{A Competência Legislativa Privativa Estadual}

O modelo federativo por natureza defere aos Estados-membros a autonomia legislativa, condicionada, contudo, expressamente pelos princípios estruturantes da Constituição Federal. O federalismo nacional segue essa regra estrutural, nos termos do art. 25 caput da CF: Os Estados organizam-se e regem-se pelas Constituições e leis que adotarem, observados os princípios desta Constituição. Por sua vez, o parágrafo do artigo, dispõe: São reservadas aos Estados as competências que não lhe sejam vedadas por esta Constituição.

Fernanda Dias Menezes de Almeida leciona, assim, que será, portanto, dos Estadosmembros tudo o que não se incluir entre as competências enumeradas da União e dos

\footnotetext{
${ }^{37}$ Art. 34. A União não intervirá nos Estados nem no Distrito Federal, exceto para:

I - manter a integridade nacional;

II - repelir invasão estrangeira ou de uma unidade da Federação em outra;

III - pôr termo a grave comprometimento da ordem pública;

IV - garantir o livre exercício de qualquer dos Poderes nas unidades da Federação;

V - reorganizar as finanças da unidade da Federação que:

a) suspender o pagamento da dívida fundada por mais de dois anos consecutivos, salvo motivo de força maior;

b) deixar de entregar aos Municípios receitas tributárias fixadas nesta Constituição, dentro dos prazos estabelecidos em lei;

VI - prover a execução de lei federal, ordem ou decisão judicial;

VII - assegurar a observância dos seguintes princípios constitucionais:

a) forma republicana, sistema representativo e regime democrático;

b) direitos da pessoa humana;

c) autonomia municipal;

d) prestação de contas da administração pública, direta e indireta.

e) aplicação do mínimo exigido da receita resultante de impostos estaduais, compreendida a proveniente de transferências, na manutenção e desenvolvimento do ensino e nas ações e serviços públicos de saúde.
} 
Municípios, bem como não incida no campo das vedações constitucionais ${ }^{38}$ - conforme a seguir explicitado. É o que chamamos de competência remanescente.

Emblemática, portanto, a ênfase constitucional da autonomia dos Estados, qual seja, a liberdade política de eleger o seu próprio governo e de prover o seu peculiar destino, através das suas próprias leis, elaboradas pelos autênticos representantes do seu povo, escolhidos no âmbito territorial do Estado-membro. Eis o sentido da competência privativa dos Estados, o poder de autodeterminação exercitável de modo independente na faixa de sua competência positivada pela Carta inaugural - condicionada, no entanto, aos princípios da Carta Federal.

A autonomia dos Estados-membros é de importância crucial para o federalismo, tanto que a doutrina a qualifica como traço característico do Estado Federal, elemento essencial à configuração do federalismo. ${ }^{39}$ Assim, a autonomia dos entes federados estende-se até os limites traçados na Constituição Federal.

Justamente por se cuidar de poder condicionado, a autonomia não se confunde com a soberania, esta é apanágio exclusivo do todo, a Federação, cuja independência é máxima; enquanto que na autonomia a independência é condicionada sob o plano da federação, pelo seu espírito de unidade, direitos fundamentais, a forma de governo e os princípios estruturais. Procurar-se-á expor quais são esses princípios, mencionados pelo constituinte, ao condicionar a competência legislativa dos Estados membros.

A origem nacional da explicitação dos princípios condicionantes aos Estados-membros adveio com a Reforma Constitucional de 1926 para o fim de melhor integrar as Constituições Estaduais, cujo exemplo mais marcante de tal necessidade foi a Constituição Estadual do Rio Grande do Sul, que adotara uma organização sui generis, completamente diferente dos demais Estados, o que acarretou distúrbios institucionais e políticos ${ }^{40}$.

Deveras, a história do constitucionalismo pátrio descreve um movimento pendular dessa condicionante federativa; inicialmente marcada por uma ampla abertura, dada a ausência de enumeração expressa desses princípios constitucionais, posteriormente assistiu-se uma intervenção excessiva nos Estados-membros, marcada pelo chamado federalismo de integração na vigência da Carta de 1967/69. Já o constituinte de 1988 procurou conferir maior

\footnotetext{
${ }^{38}$ ALMEIDA, 2007, p. 103.

${ }^{39}$ HORTA, 1964, p. 13.

${ }^{40}$ FERRAZ, Anna Cândida da Cunha. Poder constituinte do Estados-membro. Revista dos Tribunais. São Paulo, 1979, p. 150-151.
} 
amplitude autônoma ao Poder Constituinte Decorrente, através de uma limitação condicionante mais tênue e principiológica.

Necessário frisar, pois, que a diretriz histórica do federalismo atual procura conferir maior liberdade aos Estados-membros para firmar sua autolegislação ${ }^{41}$, de sorte que a autodeterminação dos Estados-membros constitui a regra, consoante a dicção do artigo 25 da CF; já as vedações e limitações aos Estados merecem interpretação restrita, justamente por se tratar de exceção.

Tal constatação advém do mero cotejo de tais limitações expressas e principiológicas firmadas na Carta de 1967/69 e da vigente Constituição Federal, pois ao compará-las nota-se maior desapego às condicionantes expressas, então vigentes nos arts. 13 e 200 da Carta anterior $^{42}$ - baseada em longa lista de regras de observância necessária - ao passo que o constituinte de 1988 utilizou-se de limitações de índole principiológicas e institutos de extensão normativa.

Anna Cândida da Cunha Ferraz ilustra a sistemática condicionante dos princípios estruturantes do federalismo na conjugação da competência legislativa dos Estados-membros em cotejo com a coesão exigida pela Federação, nos seguintes termos:

\begin{abstract}
a limitação do Poder Constituinte Decorrente é da essência do próprio federalismo. Impossivel conceber um Estado Federal em que as unidades federativas gozem da plenitude do poder, ou detenham soberania. As unidades de uma federação, os Estados-membros, já se disse, têm apenas autonomia constitucional limitada, ou, em outras palavras, dispõem de capacidade de auto-organização e têm competência normativa própria.

Por outro lado, essa limitação do Poder Constituinte Decorrente não pode ser tal, que sufoque os Estados-membros. A virtude fundamental do federalismo - a unidade nacional através da diversidade regional - indica que para que o Estado Federal subsista, há um grau mínimo de autonomia constitucional das entidades federativas, o que implica dizer que, na linha desses graus máximo e mínimo, estão os pontoslimites das restrições da amplitude da ação do Poder Constituinte Decorrente. ${ }^{43}$
\end{abstract}

Prossegue a mestra do Largo de São Francisco noutra obra ${ }^{44}$ que é impossível fixar teoricamente, em termos ideais, os dois pontos-limites (entre o grau mínimo e o máximo de

\footnotetext{
${ }^{41}$ Nesse mesmo sentido leciona LOBO, 1989, p. 87-104.

${ }^{42}$ Em comparação com o regime constitucional anterior, diante do cotejo dos artigos 13 e 200 da Carta anterior em face do art. 25 da presente.

${ }^{43}$ FERRAZ, Anna Cândida da Cunha. União, Estados e Municípios na Nova Constituição: Enfoque Jurídicoformal. A Nova Constituição Paulista. São Paulo: Fundação Faria Lima/Fundação de Desenvolvimento Administrativo, 1989b, p. 54.

${ }^{44}$ FERRAZ, 1979, p. 135-136.
} 
intervenção), de forma que a experiência constitucional recomenda que tais parâmetros sejam retirados do Poder Constituinte Originário, dos subsídios que a doutrina oferece em cotejo com a realidade institucional, pois a essência do federalismo clama não somente pela técnica de repartição de poderes, como também pelo conjunto de valores essenciais a preservar.

As citadas condicionantes ao Poder Constituinte Decorrente têm implicações de ordem positiva e negativa. Essa última fixa um campo de proibição (de não contrariar seus preceitos), qual seja, a necessidade de seguir as disposições da Carta Federal quando explicita comandos diretos, tanto porque fundamento último de validade da ordem jurídica nacional.

Como exemplo das limitações negativas da competência legislativa, pode-se mencionar entre outros o art. 19 da CF, que veda aos Estados, Distrito Federal e Municípios estabelecer cultos religiosos ou igrejas, embaraçar-lhes o funcionamento ou manter com eles relações de dependência, ressalvada, na forma da lei, a colaboração de interesse público; recusar fé aos documentos públicos; criar distinções entre brasileiros, ou preferências entre os entes federados - em homenagem ao princípio da isonomia e da coexistência harmônica entre os entes federados. Outros tantos preceitos guardam essas orientações, cujas regras vedam a conspurcação do Poder Público em determinadas searas, como, por exemplo, dos direitos fundamentais, entre esses a garantia da observância do princípio da isonomia, das liberdades públicas em geral - como a liberdade de pensamento, de acessibilidade à função pública, de expressão cultural.

As garantias constitucionais tributárias são também limites negativos a todos os entes políticos, como a igualdade de tratamento tributário entre os contribuintes que se encontrem em mesma situação equivalente (art. 150, II); veda-se, assim: a) estabelecer limitações ao tráfego de pessoas ou bens por meio de tributos interestaduais ou intermunicipais, ressalvada a cobrança de pedágio (art. 150, V); b) instituir impostos sobre patrimônio, renda ou serviços, uns dos outros (art. 150, VI); c) a instituição de tributo que não seja uniforme em todo o território nacional ou que implique distinção ou preferência em relação a Estado, ao Distrito Federal ou a Município, em detrimento de outro, admitida a concessão de incentivos fiscais destinados a promover o equilíbrio do desenvolvimento sócio-econômico entre as diferentes regiões do País (art. 15I, I); d) quanto aos Estados, ao Distrito Federal e aos Municípios vedase estabelecer diferença tributária entre bens e serviços de qualquer natureza, em razão de sua 
procedência ou destino - tais vedações advêm do princípio mãe do federalismo, qual seja, o da igualdade constitucional entre os Estados.

Já as implicações de ordem positiva repercutem sobre a necessidade dos Estados assimilarem modelos padrões firmados pelo constituinte. Por sua vez, Manoel Gonçalves Ferreira Filho ${ }^{45}$ rotula de "pré-ordenação institucional" os preceitos constitucionais que definem as regras da estrutura dos órgãos estaduais, ou seja, que versem sobre a autoorganização e autogoverno dos Estados, tal como as regras de duração do mandato dos eleitos, de imunidades, remuneração, perda de mandato, etc. Tais regras são firmadas diretamente ou por meio de extensão normativa aos comandos lançados às instituições federais e sua extensão aos Estados (i.e. art. 27, $\S 1^{\circ}$ da $\mathrm{CF}$ ).

Outro exemplo dessa extensão normativa advém do art. 75 da $\mathrm{CF}^{46}$, oportunidade em que o constituinte estendeu a aplicação das normas sobre a fiscalização contábil e financeira da Administração Pública para a composição dos Estados-membros e Municípios e respectivos Tribunais de Contas dos Estados.

Já quando as determinações constitucionais formatam o instituto regrado, Ferreira Filho qualifica tais regras como de "subordinação normativa", como nas determinações voltadas aos princípios da Administração Pública, pois editadas para todos os entes federados, (arts. 37 a 39). As regras de subordinação normativa podem ser diretas, quando firmadas na própria Constituição Federal, com imperativos imediatos à Administração estadual; ou indiretas, quando se faz por meio de legislação nacional obrigatória para todos os Estados.

As disposições fixadas nos artigos 34 a 36 da Carta de 1988 também firmam o fulcro constitucional a ser seguido por todos os entes federados: resumidamente são a forma republicana, o sistema representativo, o regime democrático, a temporariedade das funções eletivas, a separação de Poderes, a autonomia municipal e a prestação de contas da administração pública direta e indireta. Disso decorre que o constituinte estadual deve moldar sua legislação com os mesmos predicados supra.

\footnotetext{
${ }^{45}$ FERREIRA FILHO, Manoel Gonçalves. Comentários à Constituição Brasileira de 1988. São Paulo: Saraiva, 1990a, v. 1, p. 203.

${ }^{46}$ Art. 37. A administração pública direta e indireta de qualquer dos Poderes da União, dos Estados, do Distrito Federal e dos Municípios obedecerá aos princípios de legalidade, impessoalidade, moralidade, publicidade e eficiência e, também, ao seguinte: (...)

Art. 75. As normas estabelecidas nesta seção aplicam-se, no que couber, à organização, composição e fiscalização dos Tribunais de Contas dos Estados e do Distrito Federal, bem como dos Tribunais e Conselhos de Contas dos Municípios.
} 
Por isso podemos denominar de regras de simetria os preceitos expressos na Constituição Federal que fundam a estrutura de regência do Estado, como aquelas que refletem o inter-relacionamento entre os Poderes, tal como disciplinado no âmbito federal. Assim, o Estado-membro deve seguir essa mesma linha quanto à relação dos Poderes, tal como decidiu o $\mathrm{STF}^{47}$ quanto às regras básicas do processo legislativo, em especial a iniciativa reservada de lei e os limites de emenda parlamentar.

Essa orientação reconhece a inconstitucionalidade de normas estaduais que subordinam a eficácia de convênios celebrados por Secretários de Estado ou de seus atos e contratos à aprovação da Assembléia Legislativa, justamente para preservar a independência e harmonia entre os Poderes.

Releva notar, contudo, que as regras de simetria só se circunscrevem às categorias fundamentais de organização da Carta Federal ou ao chamado fulcro constitucional estabelecido aos entes federados.

Enfim, as regras condicionantes do Poder Constituinte Decorrente aplicam-se não só à legislação estadual como à municipal, e nesses termos é que deve ser compreendida a ressalva contida na cabeça do artigo 25, cuja síntese do acima exposto é sintetizado por Tércio Sampaio Ferraz Júnior ${ }^{48}$ :

Os princípios fundamentais originários, instituídos, de reconhecimento e teleológicos constituem o núcleo sensível da Constituição Federal de tal modo que a constituinte estadual neles encontra a condição fundamental de sua principialidade decorrente. Neste sentido, eles são intocáveis, pois alterá-los é colocar-se como constituinte originário.(...) A Constituição, porém, ao instituir o princípio federativo, já delineia a federação, estabelecendo-lhe certos princípios comuns de organização (...) Dentre eles mencionem-se os constantes do art. 37, referentes à Administração Pública dos quatros entes políticos da Federação e comuns a eles. São eles o princípio da legalidade, impessoalidade, moralidade e publicidade (que são, aliás, seguidos de regras comuns a todos eles). Aqui se incluem (...) o plano de carreira dos servidores,(...), o princípio da proporcionalidade eleitoral (art. $45 \mathrm{c} / \mathrm{c}$ art. $27 \mathrm{e}$ art. 29, IV), os do art. 93 referentes à magistratura, os do art. 145, $1^{\circ}$ (pessoalidade e gradualidade, conforme a capacidade contributiva, dos tributos [sic]), os do art. 150 (anterioridade na estatuição dos tributos) e ainda os do art. 170 (Ordem Econômica).

(...)Ora, a aceitarem-se estes comentários, devemos fazer notar que, quando a Constituição Federal fala em "observados os princípios desta Constituição", referindo-se ao constituinte estadual, reporta-se genericamente a princípios e regras, sem maiores distinções. (...) Com respeito às regras devemos reconhecer,

\footnotetext{
${ }^{47}$ Cf. ADI 97/RO. Entendeu-se que a regra de reserva de iniciativa de lei é importante aspecto no desenho da tripartição dos poderes, de sorte que os Estados-membros a ele se vinculam. Cf. ainda ADI 276 e 822.

48 FERRAZ JUNIOR, Tércio Sampaio. Princípios Condicionantes do Poder Constituinte. Revista de Direito Público no 92,1989 , p. 35-42.
} 
ademais, que nem todas contêm vedações expressas. Assim, p. ex., o art. 19 contém regras que vedam à União, Estados, Distrito Federal e Municípios expressamente, certos comportamentos normativos ( $p$. ex., recusar fé a documentos públicos, criar distinções entre brasileiros ou preferências entre si etc). Outras disciplinam a competência legislativa comum, concorrente e suplementar (art. 22, parágrafo único, arts. 23 e 24). Os $p$ p $1^{\circ}$ a $4^{\circ}$ do art. 24 contêm regras para a disciplina das competências suplementar e concorrente. A distribuição de competências, por meio de regras, contém, porém, a contrario sensu vedações para o constituinte estadual. Em outros casos ainda, a Constituição Federal estende, compulsoriamente, aos Estados certas regras, como é o caso do art. 27, $p 1^{\circ}$, em que se manda aplicar as regras desta Constituição sobre o sistema eleitoral, inviolabilidade, imunidades, remuneração, perda de mandato, licença, impedimentos e incorporação às Forças Armadas.

Refere-se aqui o autor aos deputados estaduais, intromissão direta aos limites de organização dos Poderes do Estado-membro, em detrimento da autonomia desses, mas prestigiada em prol de um amálgama organizacional mínimo à federação, bem como para correção de assimetrias de fato, inclusive culturais, de Estados descompromissados com os gasto públicos. Outro exemplo marcante é a Lei de Responsabilidade Fiscal (Lei Complementar $n^{\circ} 101$ ), cuja eficácia é nacional ${ }^{49}$, com disposições expressas para os Estados e

\footnotetext{
${ }^{49}$ Note-se que o STF sufragou quase a totalidade das disposições da Lei de Responsabilidade Fiscal, eis que na $\mathrm{ADI}^{\circ} 2.250$ não se reconheceu inconstitucionalidade. Já na ADI n 2.238 o STF assim deliberou:

EMENTA: CONSTITUCIONAL. MEDIDA CAUTELAR EM AÇÃO DIRETA DE INCONSTITUCIONALIDADE. LEI COMPLEMENTAR N ${ }^{\circ} 101$, DE 04 DE MAIO DE 2000 (LEI DE RESPONSABILIDADE FISCAL). MEDIDA PROVISÓRIA No 1.980-22/2000. Lei Complementar $\mathrm{n}^{\circ} 101 / 2000$. Não-conhecimento. I - Os $\S \S 2^{\circ}$ e $3^{\circ}$ do art. $7^{\circ}$ da $L C n^{\circ} 101 / 00$ veiculam matérias que fogem à regulação por lei complementar, embora inseridas em diploma normativo dessa espécie. Logo, a suposta antinomia entre esses dispositivos e o art. $4^{\circ}$ da Medida Provisória $n^{\circ} 1.980-22 / 00$ haverá de ser resolvida segundo os princípios hermenêuticos aplicáveis à espécie, sem nenhuma conotação de natureza constitucional. Ação não conhecida. II Ação prejudicada quanto ao inciso I do art. 30 da $\mathrm{LC}^{\circ}$ 101/00, dado que já expirado o prazo da norma de caráter temporário. Lei Complementar no 101/2000. Vício formal. Inexistência. III - O parágrafo único do art. 65 da Constituição Federal só determina o retorno do projeto de lei à Casa iniciadora se a emenda parlamentar introduzida acarretar modificação no sentido da proposição jurídica. IV - Por abranger assuntos de natureza diversa, pode-se regulamentar o art. 163 da Constituição por meio de mais de uma lei complementar. Lei Complementar $n^{\circ} 101 / 200$. Vícios materiais. Cautelar indeferida. V - O inciso II do $\S 2^{\circ}$ do art. $4^{\circ}$ apenas obriga Estados e Municípios a demonstrarem a viabilidade das metas programadas, em face das diretrizes traçadas pela política econômica do Governo Federal (políticas creditícia e de juros, previsões sobre inflação, etc.), o que não encontra óbice na Constituição. VI - Art. $4^{\circ}, \S 4^{\circ}$ : a circunstância de certos elementos informativos deverem constar de determinado documento (Lei de Diretrizes Orçamentárias) não impede que venham eles a ser reproduzidos em outro, principalmente quando destinado à apresentação do primeiro, como simples reiteração dos argumentos nele contidos. VII - Art. $7^{\circ}$, caput: norma de natureza fiscal, disciplinadora da realização da receita, e não norma vinculada ao Sistema Financeiro Nacional. VIII - Art. $7^{\circ}$, § $1^{\text {o: }}$ a obrigação do Tesouro Nacional de cobrir o resultado negativo do Banco Central do Brasil não constitui utilização de créditos ilimitados pelo Poder Público. IX - Arts. $9^{\circ}, \S 5^{\circ}, 26, \S 1^{\circ}, 29, \S 2^{\circ}$ e 39 , caput, incisos e parágrafos: o Banco Central do Brasil age, nos casos, como executor da política econômica, e não como órgão central do Sistema Financeiro Nacional. X - Art. 11, parágrafo único: por se tratar de transferências voluntárias, as restrições impostas aos entes beneficiários que se revelem negligentes na instituição, previsão e arrecadação de seus próprios tributos não são incompatíveis com o art. 160 da Constituição Federal. XI - Art. 14, inciso II: medida cautelar indeferida. XII Art. 15: o dispositivo apenas torna efetivo o cumprimento do plano plurianual, das diretrizes orçamentárias e dos
} 
Municípios, sufragada pelo federalismo de equilíbrio almejado pelo constituinte, com fundamento nos arts. 163 a 169.

A observância desses comandos deve ser entendida como a necessidade de se legislar através de parâmetros compatíveis que concretizem os citados preceitos, sob pena de se incorrer em inconstitucionalidade, ou até mesmo intervenção federal, nas hipóteses contidas no art. 34 da Constituição Federal.

orçamentos anuais, não inibindo a abertura de créditos adicionais previstos no art. 166 da Carta Política. XIII Art. 17 e $\S \S 1^{\circ}$ a $7^{\circ}$ : que o aumento de despesa de caráter continuado esteja condicionado à redução de despesa ou aumento de receita, também em caráter continuado, é proposição que, por achar-se em sintonia com a lógica, não pode ser obviamente considerada responsável pelo engessamento de qualquer dos Poderes de Estado ou órgãos da Administração e, portanto, ofensiva ao princípio da separação dos Poderes. Pela mesma razão, não se pode ver como atentatória ao princípio da autonomia dos entes federados. $\mathrm{O}$ incremento da arrecadação pelas formas indicadas no $\S 3^{\circ}$ do art. 17 da LRF se reveste de previsibilidade e se presta, por isso, para um cálculo de compensação, que há de ser, tanto quanto possível, exato. XIV - Art. 18, § 1º: a norma visa a evitar que a terceirização de mão-de-obra venha a ser utilizada com o fim de ladear o limite de gasto com pessoal. Tem, ainda, o mérito de erguer um dique à contratação indiscriminada de prestadores de serviço, valorizando o servidor público e o concurso. XV - Art. 20: o art. 169 da Carta Magna não veda que se faça uma distribuição entre os Poderes dos limites de despesa com pessoal; ao contrário, para tornar eficaz o limite, há de se dividir internamente as responsabilidades. XVI - Art. 24: as exigências do art. 17 da LRF são constitucionais, daí não sofrer de nenhuma mácula o dispositivo que determina sejam atendidas essas exigências para a criação, majoração ou extensão de benefício ou serviço relativo à seguridade social. XVII - Art. 29, inciso I: não se demonstrou qual o dispositivo da Constituição que resultou malferido. XVIII - Art. 59, $\S 1^{\circ}$, inciso IV: trata-se de dispositivo que prevê mera advertência. XIX - Art. 60: ao Senado Federal incumbe, por força dos incisos VII e IX do art. 52 da Constituição Federal, fixar limites máximos, norma que não é violada enquanto os valores se situarem dentro desse âmbito. XX - Art. 68, caput: o art. 250 da Carta-Cidadã, ao prever a instituição de fundo integrado por bens, direitos e ativos de qualquer natureza, não excluiu a hipótese de os demais recursos pertencentes à previdência social, até mesmo os provenientes da arrecadação de contribuições, virem a compor o referido fundo. Ademais, nada impede que providência legislativa de caráter ordinário seja veiculada em lei complementar. Lei Complementar $n^{\circ}$ 101/2000. Interpretação conforme a Constituição. XXI - Art. 12, § 2ª medida cautelar deferida para conferir ao dispositivo legal interpretação conforme ao inciso III do art. 167 da Constituição Federal, em ordem a explicitar que a proibição não abrange operações de crédito autorizadas mediante créditos suplementares ou especiais com finalidade precisa, aprovados pelo Poder Legislativo. XXII Art. 21, inciso II: conferida interpretação conforme a Constituição, para que se entenda como limite legal o previsto em lei complementar. XXIII - Art. 72: dada interpretação conforme, para considerar a proibição contida no dispositivo legal restrita aos contratos de prestação de serviços permanentes. Lei Complementar $\mathrm{n}^{\circ}$ 101/2000. Vícios materiais. Cautelar deferida. XXIV - Art. $9^{\circ}, \S 3^{\circ}$ : hipótese de interferência indevida do Poder Executivo nos demais Poderes e no Ministério Público. XXV - Art. 23, $\S 1^{\circ}$ e $2^{\circ}$ : a competência cometida à lei complementar pelo $\S 3^{\circ}$ do art. 169 da Constituição Federal está limitada às providências nele indicadas, o que não foi observado, ocorrendo, inclusive, ofensa ao princípio da irredutibilidade de vencimentos. Medida cautelar deferida para suspender, no $\S 1^{\circ}$ do art. 23 , a expressão "quanto pela redução dos valores a eles atribuídos", e, integralmente, a eficácia do $\S 2^{\circ}$ do referido artigo. XXVI - Art. 56, caput: norma que contraria o inciso II do art. 71 da Carta Magna, tendo em vista que apenas as contas do Presidente da República deverão ser apreciadas pelo Congresso Nacional. XXVII - Art. 57: a referência a "contas de Poder", no $\S 2^{\circ}$ do art. 57, evidencia a abrangência, no termo "contas" constante do caput do artigo, daqueles cálculos decorrentes da atividade financeira dos administradores e demais responsáveis por dinheiros, bens e valores públicos, que somente poderão ser objeto de julgamento pelo Tribunal de Contas competente (inciso II do art. 71 da Constituição). Medida cautelar deferida. Medida Provisória no 1.980-22/2000. Ação prejudicada. XXVIII - Arts. $3^{\circ}$, I, e $4^{\circ}$ : diploma normativo reeditado, sem que houvesse pedido de aditamento da petição inicial após as novas edições. Ação prejudicada, nesta parte. 
Sopesados esses condicionamentos de natureza constitucional, o campo legislativo estadual é de natureza remanescente, conforme reza o parágrafo primeiro do art. 25 , fórmula do federalismo clássico, deveras abrandado pela riqueza integradora da $\mathrm{CF}$ e seus preceitos de pré-ordenação institucional, a qual aguça alguns constitucionalistas a afirmar que os Estados se encontram em área de atuação restrita. Caberá à criatividade e argúcia do parlamentar estadual arquitetar leis que transcendam essa suposta limitação constitucional dos Estados membros.

Emerge daí a assertiva que limitações à autonomia estadual através de princípios implícitos não corresponde aos valores da Carta de 1988, diante dos princípios e regras explícitas nesse sentido. ${ }^{50}$

Exemplo dessa discussão é a polêmica sobre a possibilidade ou não do uso de medidas provisórias por parte dos Estados e sua consequente extensão aos Municípios. Muito já se debateu sobre o tema e finalmente a discussão chegou ao Supremo Tribunal Federal ${ }^{51}$, que amparou a autonomia de auto-organização do Estado-membro para elaborar conforme suas próprias diretrizes a possibilidade do uso de medidas provisórias na Constituição do Estado.

Contudo, sua formatação deverá seguir os mesmos moldes expressos ao instituto, isto é, reserva-se aos casos de relevância e urgência; com as mesmas limitações materiais, expressas em nível federal; a submissão à apreciação parlamentar para conversão em lei e possuir regime de prazos para conversão no mínimo tão rigoroso quanto o federal, consoante leciona José Levi do Amaral Júnior. ${ }^{52}$

Prossegue o estudioso em Tese de Doutoramento sobre o tema ${ }^{53}$ :

Especificamente no que toca à decretação de urgência no âmbito estadual, o mais importante desses princípios é a necessidade e obrigatória submissão da medida provisória estadual à Assembléia Legislativa para conversão em lei. Isso porque a conversão é, a um só tempo elemento integrante e mecanismo garantidor da separação de Poderes tal qual concebida pela Constituição de 1988. (...) Há mais: o processo de conversão em lei não pode excluir a emendabilidade da decretação de urgência estadual. Isso porque, como já referido, a possibilidade de emenda parece ser consubstancial ao processo de conversão em lei, bem como à necessária preservação da função legislativa do Parlamento.

\footnotetext{
${ }^{50}$ Nesse mesmo sentido: FERREIRA FILHO, 1990a, p. 202 e ALMEIDA, 2007, p. 107-108.

${ }^{51}$ Tribunal Pleno, ADIn 425-5-TO, rel. Min. Maurício Corrêa, DJ 19.12.2003.

${ }^{52}$ AMARAL JUNIOR, José Levi do. Medida Provisória e sua conversão em Lei: a emenda constitucional n. 32 e o papel do Congresso Nacional. São Paulo: Editora Revista dos Tribunais, 2004, p. 196-197.

${ }^{53}$ AMARAL JUNIOR, 2004, p. 194-196.
} 
Realmente, a separação de Poderes é forma de divisão horizontal de competências para o fim de melhor garantir a excelência do uso do poder, fiel às lições de Montesquieu, que delineou a visão tripartite do Estado, cuja lógica é extensível aos demais entes federados ${ }^{54}$.

Registre-se, por oportuno, que o uso de medida provisória aos Estados importa na maior autonomia dos entes federados regionais às condicionantes do poder central, cuja comprovação histórica advém da vedação do uso de decreto-leis (diploma normativo congênere à espécie) aos Estados pela Constituição de 1967, art. 200, parágrafo único.

\subsection{Competência Legislativa Privativa do Distrito Federal}

O Distrito Federal tem Brasília como a sede da Capital da República, e assume papel de ente federado próprio, goza de peculiaridade ímpar, pois acumula as competências próprias de um Estado-membro, bem como as Municipais. Como ensina José Afonso da Silva, o Distrito Federal surgiu da transformação do antigo Município neutro, que era a sede da corte e capital do Império. Não é Estado. Não é Município. Contudo, congrega simultaneamente as competências legislativas e tributárias desses últimos ${ }^{55}$. Sua origem tem, portanto, conotação de resguardo da soberania nacional, pois visa melhor localização operacional e geopolítica da Capital Federal, sede da Federação.

A Carta Magna de 1988 elevou, pois, o Distrito Federal à condição de ente federativo ente autônomo nos termos e limites constitucionais. Dispôs expressamente que ao Distrito Federal são atribuídas as competências legislativas reservadas aos Estados e Municípios (art. $32, \S 1^{\circ}$ e 147 da CF). Contudo, reservou à União a tutela e a legislação sobre organização judiciária, do Ministério Público e da Defensoria Pública, bem como da polícia civil e militar e do corpo de bombeiros militar, todos mantidos e organizados pela União, cuja utilização desses últimos é regrada por lei federal. Daí a conotação de que o Distrito Federal é tutelado pela União Federal sob alguns aspectos.

Cabe, pois, ao Distrito Federal as competências remanescentes que são reservadas aos Estados, firmadas no art. $25, \S 2^{\circ}$, bem como as competências locais atribuídas então aos

\footnotetext{
${ }^{54}$ Fica a questão se também os Municípios podem adotar o uso da medida provisória, através de suas Leis Orgânicas. Quando o Estado-membro adota para si o uso da medida provisória, certamente que sim. Contudo, quando não o faz, ter-se-á obrigatoriedade de sua extensão aos Municípios? O assunto será examinado no âmbito da competência privativa municipal.

${ }^{55}$ SILVA, 2006, p. 649.
} 
Municípios, já que ao Distrito Federal é vedado dividir-se em Municípios. Goza, portanto, o Distrito Federal de autonomia político-constitucional expressa na própria Carta Política de 1988, princípio estruturante de sua organização institucional e da Federação brasileira, qualificando-se como prerrogativa política, de sorte que somente no âmbito da Constituição Federal ter-se-á os limites de sua autonomia, tal como desenhada.

Sua auto-organização é firmada através de Lei Orgânica, aprovada pela Câmara Legislativa, atendidos os princípios da Constituição Federal, com plena similitude para a eleição de seu Governador, Vice-Governador e Deputados Distritais.

Nos termos de sua Lei Orgânica, em cotejo com a Constituição Federal, Brasília é ao mesmo tempo Capital da Federação, isto é, da República Federativa do Brasil, e também sede do governo do Distrito Federal. Sua arquitetura apresenta expressivo simbolismo de poder, cuja Praça dos Três Poderes representa o pólo irradiante do poder republicano para toda a Federação.

Nesse contexto, não se vislumbra a possibilidade de criação no Distrito Federal de regiões metropolitanas, microrregiões e aglomerações urbanas, pois ausente fundamento constitucional para tanto, diante do preceito constitucional que veda sua divisão em Municípios, logo não há que se falar juridicamente em regiões metropolitanas no âmbito do Distrito Federal.

Dada a acumulação das atribuições administrativas e prerrogativas legislativas próprias dos Estados e dos Municípios sobre os ombros do Distrito Federal, sua interação legislativa se faz tão somente com as normas federais, seja no âmbito da competência privativa ou concorrente, entre essas a legislação referente ao seu Poder Judiciário, ao Ministério Público, Defensoria Pública, polícia civil e militar e do corpo de bombeiros, pois todos são organizados e mantidos pela União Federal (art. 21, XIII e 32, § $4^{\circ}$, da CF). Nesse sentido, menores as chances de conflitos de normas entre tais entes federados.

Assim, salvo quanto às exceções supra apontadas, a mesma lógica apresentada para a interpretação das normas estaduais e municipais aplica-se para a interpretação das normas distritais. A seguir, segue-se a apresentação das competências municipais. 


\subsection{A Competência Legislativa Privativa Municipal}

O federalismo brasileiro tem como originalidade a inclusão dos Municípios como componentes federados na República Federativa do Brasil, frisado já na abertura da Carta Constitucional no art. $1^{\circ}$, que determina a união indissolúvel dos Estados e Municípios e do Distrito Federal, constituindo um único Estado de Direito. O disposto no art. 18 reforça o status federado do Município ao tratar da Organização do Estado, determinando que a organização político-administrativa de nossa República compreende os supracitados entes, todos autônomos, nos termos da Constituição.

Deveras, já é antiga a tradição brasileira quanto ao reconhecimento da autonomia administrativa aos Municípios, pois desde a primeira Carta Republicana concedeu-se balizada autonomia aos Municípios na regência dos interesses locais, tal como estabelece o art. 68 da Carta de $1891^{56}$. Nesse contexto, alguns doutrinadores endossam a afirmação de que nossa Federação, desde o berço, desenvolveu-se em três planos, nela se identificando não a tradicional divisão entre a ordem central e ordens estaduais, mas uma tríplice estrutura que compreende a ordem central, a ordem estadual/regional e a ordem municipal - nominado por Charles Durand como federalismo de duplo grau ${ }^{57}$, pois com dois círculos de autonomia, uma do Estado-membro e outra do ente local.

Dessa posição singular do Município brasileiro é que resulta a sua autonomia políticoadministrativa, diversamente do que ocorre nas demais Federações, em que o Município é circunscrição territorial meramente administrativa.

Assim, a própria Lei Fundamental pôs fim ao debate que então reinava na doutrina sobre a natureza jurídica dos Municípios, porquanto restou expresso que esses são integrantes da própria Federação, peculiaridade ímpar do Estado brasileiro.

O Município é, portanto, pessoa jurídica de direito público interno, dotado de autonomia política e administrativa, organizada através da Lei Orgânica do Município, diploma que dita os fundamentos e princípios diretrizes do modelo da organização municipal visada pelo munícipe, elaborada pela própria Câmara Municipal - evolução da Carta de 1988,

\footnotetext{
${ }^{56}$ Art 68 - Os Estados organizar-se-ão de forma que fique assegurada a autonomia dos Municípios em tudo quanto respeite ao seu peculiar interesse.

${ }^{57}$ DURAND apud ALMEIDA, 2007, p. 96.
} 
pois outrora tal competência era dos Estados - o que enfatiza a autonomia política do ente federado.

Tal como a autonomia estadual, também a municipal é condicionada pelos princípios constitucionais nacionais e estaduais, conforme frisa o art. 29 da CF. Nem poderia ser diferente, pois só assim se preserva o mínimo de unidade nacional e a própria integração das unidades federadas. A autonomia municipal é firmada pela sua Lei Orgânica, cujos limites são justamente a observância dos princípios basilares do sistema nacional e estadual.

Carmen Lúcia Antunes Rocha aponta com propriedade a extensão e os limites da Lei Orgânica Municipal:

O Munícipe tem a sua condição afirmada, definitivamente, na Lei Orgânica Municipal, onde a Democracia pode ter formas de exercício que modificam substancialmente as instituições. Por isso a Lei Orgânica tem sido considerada "verdadeiro código dos Municípios" por alguns, ou uma "Minilei Fundamental" por outros. É que nela se traçam os instrumentos de ação do cidadão em sua localidade e o poder é controlado e tem a sua forma de exercício definida, em última instância, segundo as normas ali afirmadas. Poder-se-ia asseverar que o imperioso acatamento dos princípios constitucionais nacionais ou estaduais tolheria o legislador municipal, impedindo criações significativas nesse plano. Não é isso exatamente verdade, quando se leva em conta que os princípios limitadores, materialmente, do legislador municipal são aqueles que se referem à Democracia, à República, à participação popular, enfim, princípios que podem ser aplicados $e$ exercidos de variadas formas, o que permite um raio de ação do legislador bastante interessante. ${ }^{58}$

Como se vê, a Constituição amolda preceitos a serem pormenorizados pela Lei Orgânica Municipal, segundo as diretrizes da Carta Magna, como a eletividade do Prefeito, Vice-Prefeito e dos Vereadores, seus respectivos mandatos de quatro anos, mediante pleito direto e simultâneo realizado em todo País. Já a definição do número de vereadores é diretamente proporcional ${ }^{59}$ à população do Município, em sintonia com o modelo adotado para

\footnotetext{
${ }^{58}$ ROCHA, 1997, p. 291-292.

${ }^{59}$ Interessante polêmica firmou-se na mais alta Corte do País, a respeito dos desdobramentos do princípio da proporcionalidade sobre a composição do número de vereadores na Câmara Municipal, porquanto matematicamente exige-se 47.619 habitantes no Município para se ter um Vereador a mais que o mínimo constitucional, segundo o regramento constitucional do art. 29 em seu inciso IV. Essa é a orientação do julgamento por maioria do Recurso Extraordinário (RE 197917) que contestou a representação legislativa no município de Mira Estrela (SP), da necessidade de se adotar a fórmula de proporcionalidade de um vereador para cada 47.619 habitantes. Mira Estrela, tendo menos de três mil habitantes, se enquadraria no limite mínimo constitucional de nove vereadores. O RE foi movido pelo Ministério Público Estadual de São Paulo (MP/SP) contra o parágrafo único do artigo $6^{\circ}$ da Lei Orgânica (226/90) do município paulista, que fixou em onze o número de parlamentares da Câmara de Vereadores, acima, portanto, do critério matemático ora adotado no Acórdão.
} 
a Câmara dos Deputados e Assembléia Legislativa, consoante determina a Resolução no 1.702/04 do Tribunal Superior Eleitoral, editada após o julgamento do RE 197.917 pelo STF, que reconheceu a inconstitucionalidade incidenter tantum com efeitos ex nunc da norma municipal que fixou o número de vereadores em patamar desproporcional ao entabulado na Constituição Federal; fixou-se interpretação de cogente proporcionalidade entre o número de habitantes e o de vereadores, em homenagem ao princípio da força normativa da $\mathrm{CF}$, corroborado aos postulados da moralidade, impessoalidade e economicidade.

Em período anterior à querela supracitada, o STF afastou a possibilidade da Constituição Estadual fixar o número de vereadores, ao expurgar dispositivo da Constituição

Vale, contudo, mencionar os votos discordantes que ora seguem: O ministro Sepúlveda Pertence retomou o julgamento do Recurso ao proferir seu voto-vista, divergindo do ministro relator, ao julgar que os municípios têm autonomia política para determinar o maior ou menor número de vereadores que irão representar a população. "Prefiro ver no artigo 29, inciso IV um campo experimental de exercício do inédito poder de autoorganização municipal da Constituição vigente e não vejo mal em que a cada município se permita demarcar com maior ou menor grandeza numérica a representação popular na sua câmara. Certo não desconheço nem sou insensível à preocupação, várias vezes sublinhada no voto de V. Exa., Sr. Presidente, com os gastos acarretados às finanças municipais por câmaras de maior número de vereadores", votou. Pertence negou provimento ao RE, observando que conforme seja a decisão de mérito do STF a respeito da matéria reservará espaço para eventuais considerações acerca do âmbito de eficácia do julgamento. Ao antecipar seu voto, o ministro Nelson Jobim disse que os municípios optaram pela "extrapolação" dos números da proporcionalidade com finalidade eleitoral. "Um número maior de vereadores viabiliza maiores espectros de campanha eleitoral, quer para deputados, quer para senadores, quer para candidatos a prefeito municipal. Ou seja, uma coligação municipal já que o número de vereadores de uma Câmara de Vereadores é a base para o número de candidatos". O ministro Marco Aurélio também antecipou voto, que seguiu a dissidência aberta pelo ministro Sepúlveda Pertence. Ao negar provimento ao Recurso Extraordinário, observou que nenhuma Emenda Constitucional fixou o número de integrantes das Câmaras de Vereadores. Considerou que, ao estabelecer a proporcionalidade na representação municipal, a Constituição Federal (inciso IV, artigo 29) não teria sido matemática, mas específica. Conforme interpretou o ministro, a determinação seria no sentido de que "se tem como proporcional à composição da câmara, proporcional à população do município, desde que se respeite, no âmbito da autonomia municipal, as balizas das três alíneas do inciso IV do artigo 29 da Constituição Federal”. Estas estabelecem os limites mínimo e máximo de representação popular. O ministro destacou que o artigo 29 da Carta previu que o município será regido por Lei Orgânica e não Complementar. Ressaltou o fato de o artigo 45, parágrafo $1^{\circ}$ de a Carta Magna prever que o número de deputados federais, estaduais e distritais será estabelecido, proporcionalmente à população, por Lei Complementar, procedendo-se aos ajustes necessários, no ano anterior às eleições, para que nenhuma daquelas unidades da Federação tenha menos de oito ou mais de setenta Deputados. "Não me consta, data vênia, que um acórdão do Supremo Tribunal Federal possa fazer às vezes de Lei Complementar", disse.

De acordo com o ministro Marco Aurélio, o Supremo só poderia declarar a inconstitucionalidade da Lei do município se a Lei Orgânica, editada no campo da autonomia municipal, tivesse desprezado os pisos e tetos fixados no inciso IV, artigo 29 da Constituição Federal. "A fixação do número de vereadores faz-se, desde que respeitado o piso e o máximo constitucionais, a partir de uma opção político-legislativa do próprio município, não havendo campo, a meu ver, para atuar-se, nessa mesma fixação, inserindo-se no cenário nacional um acórdão do Supremo Tribunal Federal com contornos e com conteúdo de verdadeira Lei Complementar. Peço vênia, portanto, para dissentir de V. Exa. Entendo a preocupação de V. Exa. numa quadra de dificuldades maiores em relação aos gastos públicos, mas, de qualquer forma, paga-se um preço por se viver em uma democracia e o preço é o respeito irrestrito, principalmente à Constituição Federal”, votou Marco Aurélio (...). 
de Tocantins que fixava a proporcionalidade do número de Vereadores diretamente na Constituição Estadual ${ }^{60}$, tarefa da Lei Orgânica Municipal, mas fiel ao modelo constitucional.

$\mathrm{O}$ constituinte sumarizou a competência dos Municípios no art. 30 da $\mathrm{CF}^{61}$, embora haja atribuições esparsas no corpo da Constituição Federal referente aos Municípios. Sustenta a competência legislativa privativa ou exclusiva no inciso I. Ampara, ainda, a competência concorrente no inciso II; a competência legislativa implícita/indireta, advinda da competência administrativa expressa nos demais incisos do mencionado artigo, sob a batuta do princípio da legalidade que preside os atos administrativos e clama pela aludida competência legislativa implícita, cuja tônica deve sempre visar o interesse local - fugiu, assim, o constituinte da técnica de separar por artigos a competência administrativa da legislativa.

O traço marcante da delimitação constitucional para aferir a legislação municipal é justamente a referência a assuntos de interesse local, conforme preconiza o art. 30, inc. I, da $\mathrm{CF}$, eis a cláusula-chave para perquirir a legitimidade do Município para legislar sobre os mais variados assuntos.

Nesses termos, temos que a mesma lógica que presidiu o entendimento da legitimidade da legislação municipal, sob a égide das Constituições anteriores, desde 1891, que previa a expressão "peculiar interesse", preside o entendimento atual. Como sustenta Fernanda Dias Menezes de Almeida, (...) a mudança da letra não equivale a uma mudança do espírito da Constituição ${ }^{62}$.

\footnotetext{
${ }^{60}$ ADIN no 1.038 , conforme consulta ao sítio do <www.stf.jus.br/jurisprudencia>.

${ }^{61}$ Art. 30. Compete aos Municípios:

I - legislar sobre assuntos de interesse local;

II - suplementar a legislação federal e a estadual no que couber;

III - instituir e arrecadar os tributos de sua competência, bem como aplicar suas rendas, sem prejuízo da obrigatoriedade de prestar contas e publicar balancetes nos prazos fixados em lei;

IV - criar, organizar e suprimir distritos, observada a legislação estadual;

V - organizar e prestar, diretamente ou sob regime de concessão ou permissão, os serviços públicos de interesse local, incluído o de transporte coletivo, que tem caráter essencial;

VI - manter, com a cooperação técnica e financeira da União e do Estado, programas de educação infantil e de ensino fundamental;

VII - prestar, com a cooperação técnica e financeira da União e do Estado, serviços de atendimento à saúde da população;

VIII - promover, no que couber, adequado ordenamento territorial, mediante planejamento e controle do uso, do parcelamento e da ocupação do solo urbano;

IX - promover a proteção do patrimônio histórico-cultural local, observada a legislação e a ação fiscalizadora federal e estadual.

${ }^{62}$ ALMEIDA, Fernanda Dias Menezes de. Competências na Constituição de 1988. São Paulo: Atlas, 1991 , p. $124-125$
} 
Eis a técnica utilizada pelo constituinte para amparar a legislação municipal. Vê-se, pois, que o constituinte não limitou rigidamente a área de competência municipal, ao revés, utilizou-se de expediente elástico para albergar a legislação municipal, critério que se atualiza com os próprios rumos da sociedade.

Arremate-se que no âmbito da competência exclusiva (art. 30, I), o Município detém autonomia constitucional plena, observado os ditames da CF, para legislar sobre assuntos de interesse preponderantemente local, de sorte que não se submete aos condicionamentos da legislação federal ou estadual, porquanto essas serão inconstitucionais na medida que tolherem o legislador municipal de sua autonomia legislativa preconizada constitucionalmente.

Já quanto ao uso de medidas provisórias, observamos que sua utilização é polêmica. Fiel à máxima do federalismo, qual seja, a consecução da unidade nacional através da diversidade regional, sem cercear o acidental, não se vislumbra óbice na sua utilização pelos Municípios, desde que respeitados os cânones constitucionais então reproduzidos na Lei Orgânica dos Municípios. Ora, se o ente central optou pelo seu uso, os demais entes federados terão autonomia para sua instituição ou não, seja na Constituição Estadual, seja na Lei Orgânica. Interpretação contrária conspurca a autonomia própria do federalismo aspirado pelo constituinte aos entes federados ${ }^{63}$.

Por derradeiro, resta frisar que a criatividade da legislação municipal deve ser melhor explorada na conjuntura nacional - e sufragada pela jurisprudência constitucional apta a solidificar nosso federalismo tripartite - de sorte que os Municípios possam usufruir com maior ênfase seus interesses e prerrogativas, sobretudo em cidades metropolitanas com desafios de auto-organização de toda sorte.

Assim, quer no âmbito do tráfego, do meio ambiente ou do ordenamento territorial da cidade, propugna-se a utilização mais acentuada da auto-organização da urbe, através de uma legislação mais enfática, que de fato expresse a prerrogativa municipal para melhor regulamentar o rodízio de veículos no tráfego urbano; a implantação de transporte coletivo movido a gás; a limitação de trânsito em áreas centrais da cidade; a recuperação de bairros através de incentivos fiscais e administrativos; a vedação ao fumo em determinadas áreas; melhor regramento dos bares/casas noturnas e até mesmo o deslocamento de indústrias poluentes para regiões menos populosas em sintonia com a política habitacional da urbe.

\footnotetext{
${ }^{63}$ Em sentido contrário Cf. AMARAL JÚNIOR, 2004.
} 
Como exemplo, segue sugestão para que a área de planejamento urbanístico ${ }^{64}$ seja albergada essencialmente pelos Municípios, com a colaboração dos Estados, onde poderia se dar vazão criativa ao dogma pluralista do federalismo: a preservação da unidade na diversidade. Tanto porque cada Município tem quadros de regionalização peculiar advindo das distintas influências de colonização e progresso social e econômico, de forma que sua arquitetura urbanística seja traçada por normas municipais, assunto de peculiar interesse municipal.

\section{6. A Competência Legislativa Concorrente}

\subsubsection{Aspectos Gerais}

Como já dito, a Constituição Federal de 1988 abordou todas as experiências constitucionais pretéritas nas técnicas de partilha de competências, ao implantar divisão de competências tanto na horizontal ou privativa como na vertical ou concorrente. Daí o sentido do nome competência concorrente, pois sobre a mesma matéria concorre mais de um ente político - tanto na competência administrativa (art. 23 da CF) como na seara legislativa (art. 24 da $\mathrm{CF}$ ), que congrega os assuntos de interesse recíproco de todos os entes federados.

A primeira experiência nacional nesse sentido adveio com a Carta de 1934, seguindo os influxos do pensamento vanguardista alemão, expresso na Constituição de Weimar de 1919, ora rearticulada no vigente texto constitucional brasileiro.

A competência concorrente constitui apurada técnica do federalismo de equilíbrio, diante da parceria de ação e responsabilidade que se estabelece entre os entes federados para a consecução de objetivos comuns e do regramento conjunto dos assuntos que extravasam o interesse de um único ente político. Cuida-se, pois, de mecanismo de descentralização política e de encargos administrativos, dada a peculiaridade de cada ente federado disciplinar determinado assunto fiel às suas peculiaridades, rumo a um progresso conjunto e planejado de toda a nação.

Das complexas relações de interdependência entre a União e os entes federados, no federalismo cooperativo, emergem a coordenação e a cooperação - a primeira é própria das

\footnotetext{
${ }^{64}$ Atualmente a União desempenha a maior parte do regramento sobre o tema, nos termos do art. 24, I, da CF e de diversas leis sobre o tema, como a Lei 6.766/79.
} 
competências concorrentes, ao passo que a segunda advém das competências materiais comuns. Observa daí Gilberto Bercovici ${ }^{65}$.

\begin{abstract}
A coordenação é, na realidade, um modo de atribuição e exercício conjunto de competências no qual os vários integrantes da Federação possuem certo grau de participação. A vontade das partes é livre e igual, com a manutenção integral de suas competências: os entes federados sempre podem atuar de maneira isolada ou autônoma. A coordenação é um procedimento que busca um resultado comum e do interesse de todos. A decisão comum, tomada em escala federal, é adaptada e executada autonomamente por cada ente federado, adaptando-se às suas peculiaridades e necessidades. A União e os entes federados concorrem em uma mesma função, mas com âmbito e intensidade distintos. Cada parte decide, dentro de sua esfera de poderes, de maneira separada e independente, com a ressalva da prevalência do direito federal. Este tipo de repartição é o previsto pelo artigo 24 da Constituição de 1988.
\end{abstract}

A técnica da competência concorrente trabalha, portanto, tanto no âmbito nacional de planejamento legislativo, ditada pelas normas gerais da União, como no âmbito estadual, através das normas estaduais que suplementam a legislação nacional de acordo com as necessidades peculiares do Estado-membro e dos interesses marcantes de sua economia - em sintonia com a tônica do federalismo, a unidade nacional através da diversidade regional. $\mathrm{Ou}$ parafraseando Diogo de Figueiredo Neto ${ }^{66}$, objetiva uniformizar o essencial sem cercear o acidental, peculiar das unidades federadas.

Congrega-se, pois, forças de duas ordens: a de centralização de um lado e a de descentralização d'outro; ou melhor, normas gerais que disciplinam uniformidade à Federação em matéria comum, através das normas da União, e normas complementares dos Estadosmembros que modulam as suas peculiaridades locais.

Fernanda Dias Menezes de Almeida ${ }^{67}$ observa com perspicácia a importância da presente técnica. Em tema de repartição de competências pode-se dizer que o que mais marca a Constituição de 1988 é a acentuada exploração das potencialidades da competência legislativa concorrente, na tentativa de se dar maior peso às ordens parciais no relacionamento federativo.

Primeiramente o constituinte cuidou da competência administrativa comum, atribuindo a todos os entes federados o ônus e conseqüente responsabilidade de zelar por assuntos de

\footnotetext{
${ }^{65}$ BERCOVICI, Gilberto. Dilemas do Estado Federal Brasileiro. Porto Alegre: Livraria do Advogado, 2004, p. 59-60.

${ }^{66}$ FIGUEIREDO NETO, Diogo de. Competência Concorrente Limitada. O problema da conceituação das normas gerais. Revista de Informação Legislativa vol 25, nº 100, vol. Brasília, out/dez 1988.

${ }^{67}$ ALMEIDA, 2007, p. 112.
} 
acentuado interesse público, conforme se infere dos doze incisos do artigo 23 da $\mathrm{CF}$, dos quais merecem ênfase a saúde, a educação, a cultura, a moradia e a proteção ao meio ambiente. A cooperação e o regime de atuação dos entes federativos no tema administrativo será orquestrada por meio de leis complementares federais de eficácia nacional ( $\left.E C \mathrm{n}^{\circ} 52\right)$, tendo em vista o equilíbrio de desenvolvimento e o bem-estar nacional, consoante dispõe o artigo 23 em seu parágrafo único. Logo, caberá ao ente central ditar o regime de execução das áreas de competência comum. Enquanto ausente tal normativa, cada ente federativo é autônomo para expressar-se ao seu alvedrio e conveniência, mas sempre visando o bem-estar nacional, objetivo maior de nossa República Federal (art. $3^{\circ}$, II, da CF).

E como já sustentado, a execução de tais tarefas administrativas pelos entes federados dá ensejo à competência legislativa indireta e concorrente para explicitação dos necessários comandos legislativos, em obséquio ao princípio da estrita legalidade, conforme leciona Anna Cândida Ferraz ${ }^{68}$ :

\begin{abstract}
As atividades a serem exercidas no campo material das competências 'comuns' somente poderão ser executadas, na generalidade dos casos, fundamentadas em regulamentação normativa precedente, oriunda de mais de um nível normativo de poder. Nesta hipótese, ocorrerá a chamada repartição vertical de competências, o que significa dizer que a atividade poderá ser exercida pelas diferentes esferas políticas, porém estará sujeita à disciplina legislativa hierarquizada e à regras gerais impostas pelo poder central.
\end{abstract}

Interessante polêmica surgiu a respeito dos convênios entre os entes políticos, porquanto, via de regra, vige a prestação de serviços públicos de execução imediata para as competências materiais privativas - onde cada esfera executa os respectivos serviços pelo próprio corpo de funcionários (p. ex. a Polícia Rodoviária Federal fiscaliza as rodovias federais) - mas se sustenta que, ainda nessa seara, quando presentes razões de política administrativa, admite-se sim o concurso de outras esferas na execução de tarefa própria de outro ente federado, ou mesmo a combinação de esforços para a consecução do bem comum mediante convênios, entre os quais pode-se citar os convênios mantidos entre a Agência Nacional de Petróleo e as Secretarias Estaduais para a fiscalização de postos de combustíveis.

Quer em face de uma interpretação evolutiva do tema no âmbito constitucional - tanto porque a Constituição anterior expressamente admitia essa concepção (art. 13, § $3^{\circ}$ ) - quer em

\footnotetext{
${ }^{68}$ FERRAZ, 1989b, p. 65.
} 
razão do rumo progressivo da prestação de serviços públicos que alberga na sua trajetória tantas outras formas associativas como desenha a história do instituto, não há razão para o impedimento de consórcios desse gênero entre os entes federados.

Necessária, contudo, a estipulação prévia e acertada do convênio, ditada pela liberdade de ingresso e saída dos seus integrantes, bem como a coordenação do serviço pelo titular da competência, o que constitui típico mecanismo de equilíbrio e coordenação de atribuições no modelo federalista adotado pela nação brasileira. Desse modo, não há inconstitucionalidade em tais convênios, nem mesmo a necessidade de sua estipulação via lei complementar, ainda que celebrados para o tema das competências administrativas privativas. Nesse sentido é a nova redação do artigo 241 da CF, positivado pela EC n ${ }^{\circ} 19$, que autoriza a gestão associada de serviços públicos entre os entes federados, regulamentada na forma da Lei n. 11.107/2005. Relevante, ainda, mencionar o disposto no art. $1^{\circ}, \S 3^{\circ}$ do Decreto $n^{\circ} 6.170 / 07$, que regulamenta os convênios e contratos de repasse da União.

\subsubsection{Sistemática e Funcionamento da Competência Concorrente Legislativa}

O constituinte tratou da competência legislativa concorrente no art. 24, em seus dezesseis incisos e quatro parágrafos ${ }^{69}$. Contudo, a Constituição ainda encampa outras searas

\footnotetext{
${ }^{69}$ Art. 24. Compete à União, aos Estados e ao Distrito Federal legislar concorrentemente sobre:

I - direito tributário, financeiro, penitenciário, econômico e urbanístico;

II - orçamento;

III - juntas comerciais;

IV - custas dos serviços forenses;

$\mathrm{V}$ - produção e consumo;

VI - florestas, caça, pesca, fauna, conservação da natureza, defesa do solo e dos recursos naturais, proteção do meio ambiente e controle da poluição;

VII - proteção ao patrimônio histórico, cultural, artístico, turístico e paisagístico;

VIII - responsabilidade por dano ao meio ambiente, ao consumidor, a bens e direitos de valor artístico, estético, histórico, turístico e paisagístico;

IX - educação, cultura, ensino e desporto;

$\mathrm{X}$ - criação, funcionamento e processo do juizado de pequenas causas;

$\mathrm{XI}$ - procedimentos em matéria processual;

XII - previdência social, proteção e defesa da saúde;

XIII - assistência jurídica e Defensoria pública;

XIV - proteção e integração social das pessoas portadoras de deficiência;

$\mathrm{XV}$ - proteção à infância e à juventude;

XVI - organização, garantias, direitos e deveres das polícias civis.

$\S 1^{\circ}$ - No âmbito da legislação concorrente, a competência da União limitar-se-á a estabelecer normas gerais.

$\S 2^{\circ}$ - A competência da União para legislar sobre normas gerais não exclui a competência suplementar dos Estados.
} 
normativas dedicadas à competência concorrente ${ }^{70}$, como os incisos IX, XXI, XXIV e XXVII do art. 22 - em que pese terem sido arroladas como competências privativas. Há ainda outros casos esparsos pela Constituição, como o disposto quanto aos emolumentos dos serviços notariais e de registro, como se infere do art. 236 do texto constitucional ${ }^{71}$, onde se denota típico caso de competência concorrente.

Em sede de competência concorrente legislativa, nossa Constituição encampou a nãocumulativa ou limitada, onde se reserva expressamente à União os níveis superiores de legislação para fixar os seus princípios diretrizes, as chamadas normas gerais de regulamentação e aos Estados-membros a complementação da legislação que lhe interessa, consoante interpretação sistemática do art. 24 e seus parágrafos.

Por meio da competência concorrente, a União estabelece as normas gerais sobre o assunto, ao passo que os Estados legislarão em caráter complementar. O $\S 3^{\circ}$, por sua vez, contempla a competência estadual legislativa plena, no caso de inexistência de lei federal sobre o tema; ao passo que o $\S 4^{\circ}$ dispõe que a superveniência de lei federal que discipline normas gerais suspende a eficácia da lei estadual, no que lhe for contrária. Atente-se, para o fato de que se cuida de suspensão dos dispositivos da norma estadual (contrários ao da lei federal) e não de sua revogação, tanto que os mesmos voltam a vigoram se revogada a lei federal.

Por sua vez, o sentido lançado no segundo parágrafo ao termo "suplementar", à luz de uma interpretação sistêmica, diz respeito tanto ao de complementar a legislação federal em pormenores, como o de supri-la na sua ausência, isto é, fazer as vezes dessa última. Já o seu advento firma a prevalência da legislação federal em caso de antinomias sobre essas, quando se cuidar de normas gerais.

Originalmente, o modelo alemão que inspirou o nosso constituinte trabalhava com a competência cumulativa nesses mesmos moldes; entretanto não havia delimitação expressa de

$\S 3^{\circ}$ - Inexistindo lei federal sobre normas gerais, os Estados exercerão a competência legislativa plena, para atender a suas peculiaridades.

$\S 4^{\circ}$ - A superveniência de lei federal sobre normas gerais suspende a eficácia da lei estadual, no que lhe for contrário.(grifamos)

${ }^{70}$ Nesse mesmo sentido leciona ARAÚJO, Marcelo de, O Condomínio Legislativo. Dissertação de Mestrado na UFPE, 2001, p. 109 e seguintes.

${ }^{71}$ Consoante se infere do art. 37 da Lei Federal no 8.935/94 e da própria Lei Federal no 10.169/00. Contudo, essa competência concorrente vige tão somente para o regramento dos custos dos serviços extrajudiciais. Já quanto às demais matérias, registro público e disposições de Direito Civil e Notarial, a matéria é de competência privativa da União Federal. 
limites prévios para o exercício da competência do ente central, de sorte que prevalecia sua legislação em caso de colisão com a lei estadual: Bundesrecht bricht Landesrecht ${ }^{72}$. Contudo, mesmo na Alemanha operou-se intensa reforma constitucional que remodelou a dinâmica da competência concorrente, pois se averiguou naquele regime a nítida sobreposição do ente central em detrimento dos demais entes federados (Länder) ${ }^{73}$.

Com efeito, o mesmo desafio permanece ao País na aferição da legitimidade da competência concorrente, qual seja, firmar a linha divisória da competência da União, expressa nas normas gerais, pois a Carta Magna atribuiu legitimidade à legislação federal tão somente em nível superior, de sorte que sua invasão em pormenores importa em inconstitucionalidade, pois se desencontra da sua atribuição constitucional legislativa. Enfim, propugna-se aqui a concretização da tônica do federalismo, a preservação da diversidade na unidade, e não a sobreposição de um ente político a outro. E somente com a atuação equilibrada dessa competência ter-se-á o equilíbrio preconizado pelos ditames constitucionais aos entes políticos.

Numerosos autores procuram identificar o sentido jurídico do termo normas gerais utilizado pela Constituição, mas são unânimes ao concluir que apesar da grande utilidade da ciência jurídica para apontar os caminhos a serem trilhados na casuística da interpretação das leis e de reduzir os subjetivismos na identificação das normas gerais, sempre haverá certa dose de incerteza para aferi-la, circunstância abonada pela análise da jurisprudência constitucional do Supremo Tribunal Federal ${ }^{74}$.

Tal circunstância advém, por certo, em razão da falta de parâmetros normativos para descrevê-las, pois a Constituição Federal não estabeleceu delimitação expressa às normas gerais, situação que só se resolverá por novo concerto constitucional à temática, como ocorreu na Alemanha ao instituir Reforma Constitucional que firmou inovações nas engrenagens dessa competência, com a instituição da "cláusula de necessidade" e "o direito de divergência dos Estados" (Länder) em determinadas matérias instituídas no âmbito da competência

\footnotetext{
${ }^{72}$ Art. 31 da Constituição Alemã.

${ }^{73}$ Cf. CRUZ, 2006, p. 125-160.

${ }^{74}$ Sobre o tema Cf. TAVARES, André Ramos. Aporias acerca do "condomínio legislativo" no Brasil: uma análise a partir do STF. Revista Brasileira de Estudos Constitucionais - RBEC, Belo Horizonte, ano 2, n. 6, abr./jun. 2008, p. 161-188.
} 
concorrente, conforme leciona Rafael Naranjo de la $\mathrm{Cruz}^{75}$, Professor de Direito da Universidad de Málaga.

Deveras, o que importa por ora é firmar os caminhos científicos para reduzir a discricionariedade do legislador e do próprio julgador, em prol de um federalismo mais saudável, como será exposto nos capítulos seguintes.

Árdua é a tarefa de conceituar normas gerais sob o ângulo positivo, daí a preferência de conceituá-las sob o prisma negativo. Positivamente, normas gerais são os lineamentos fundamentais da matéria sob regulamentação, cujo enfoque versa sobre a estrutura, as diretrizes que presidem um subsistema jurídico. De outra banda, não são normas gerais aquelas que pormenorizam a relação jurídica, ou particularizam os princípios ou bases das normas gerais às necessidades e peculiaridades regionais, consoante dispõe o art. $24, \S 3^{\circ}$.

Tércio Sampaio Ferraz Júnior ${ }^{76}$, em esclarecedor artigo, descreve sobre o assunto:

(...) Do ponto de vista da lógica jurídica, as normas podem ser quanto à quantidade, gerais, particulares ou individuais. Esta distinção pode ser vista quanto aos destinatários ou quanto aos conteúdos da norma. Uma norma é geral, quanto aos destinatários, quando se aplica à universalidade deles, sem distinções. Melhor seria, neste caso, chamá-la de norma universal. A contrario sensu, ela será particular, quando se destina a uma coletividade ou categoria dos destinatários. Melhor se falar aqui em norma especial. Por fim, é individual a que se destina a um único endereçado. Quanto aos conteúdos, as normas são gerais quando a matéria prescrita

\footnotetext{
${ }^{75}$ Nesse sentido leciona B. Tag Drucksache apud CRUZ, 2006, p. 152: "En definitiva, dentro del ámbito general de la legislación concurrente se puede, a su vez, realizar tres divisones:

1)Materias del art. 74 LF sobre las que la Federación puede ejercer su potestad legislativa sin limite ni condición alguna, pudiendo actuar los Länder sobre aquéllas solo si, y em la medida em que no lo haya hecho previamente la Federación (apartado 1).

2) Materias expressamente mencionadas em el apartado 2 del art. 74 LF, sobre lãs que la Federación unicamente puede legislar si se dan lãs circunstancias descritas en la "cláusula de necessidad". Sobre estas matérias pueden legislar los Länder em las mismas condiciones dispuestas em le apartado 1, esto es, si la Federación no ha aprobado norma alguna, o, em su defecto, em los márgenes donde la cláusula de necessidad no haya alcanzado a cubrir la actuación federal. Uma vez aprobada la legislación federal, ésta solo pdrá ser sustituida por el Derecho de los Länder si se declara por ley federal la desaparación de las circusntancias que habilitaron la intervención de la Federación.

3) Matérias expressamente recogidas em el partado 3, sobre las que la Federación puder ejercer su potestad legislativa con dos limites: uno relativo al período de vacatio legis de seis meses desde la publicación de la ley federal; y outro relativo a sua eficácia em el território de cada Estado federado, que queda condicionada a que el respectivo Estado no haya hecho uso de su $<A b$ wichungsrecht $>$. Si, por el contrario, el legislador de un Estado federado aprobara una ley divergente de la ley federal, aquélla prevalecerá sobre ésta, desplanzándola en su aplicación. Esta última circunstancia no pimpediría uma nueva intervención legislativa federal.

${ }^{76}$ FERRAZ JUNIOR, Tércio Sampaio. Uma exegese do artigo 24 da Constituição Federal. Revista Trimestral de Direito Público, São Paulo: Malheiros, p. 16-20, 1994.
} 
se reporta a toda e qualquer ocorrência da espécie (facti species, fato gerador, hipótese de incidência). Particular, quando a matéria assinala apenas um grupo ou parte da espécie. Individual, ou melhor, singular, quando sua matéria delimita um único caso.

Esquematicamente temos:

Quanto ao destinatário:

- normas universais (todos)

- normas especiais (alguns)

- normas individuais (um único)

Quanto ao conteúdo:

- normas gerais (totalidade dos casos)

- normas particulares (alguns casos)

- normas singulares (um único caso)

Assim, em princípio, do ponto de vista lógico, quando o texto constitucional atribui à União competência para legislar sobre "normas gerais", a linguagem constitucional pode estar tratando de normas gerais pelo conteúdo, ou de normas universais, isto é, gerais pelo destinatário, cabendo aos Estados e Distrito Federal, correspondentemente, a competência para o estabelecimento de normas especiais e individuais (conforme o destinatário) ou particulares e singulares (conforme o conteúdo).

A lógica, porém, ajuda mas não resolve inteiramente a questão interpretativa. A expressão constitucional - normas gerais - exige também uma hermenêutica teleológica.

Sob o mencionado aspecto lógico sempre será possível dizer que, por exemplo, quanto ao conteúdo, normas gerais prescrevem princípios, diretrizes sistemáticas, temas que se referem a uma espécie inteira e não a alguns aspectos, mas isto é insuficiente para reconhecer quando estamos diante de uma norma geral ou de uma particular. Sempre restarão dúvidas, no caso concreto, para aplicar o critério estritamente lógico-formal. Deste modo, para o intérprete, a necessidade de se analisar o conteúdo num contexto finalístico se impõe. Assim, do ângulo teleológico, a distinção há de se reportar ao interesse prevalecente na organização federativa. A federação brasileira, já pelo disposto no caput do art. $1^{\circ}$, já pela ênfase na solidariedade, na redução das desigualdades regionais, na garantia de um desenvolvimento nacional (art. $3^{\circ}$ ) aponta muito mais para um federalismo do tipo cooperativo, que exige a colaboração dos entes federativos e confere, correspondentemente, menor importância à separação e independências entre eles. Até formalmente, a mudança da expressão "Estados Unidos do Brasil", usada ainda 
em 1946, para "República Federativa do Brasil”, mostra, historicamente, este objetivo.

Ora, o federalismo cooperativo vê na necessidade de uniformização de certos interesses um ponto básico da colaboração. Assim, toda matéria que extravase o interesse circunscrito de uma unidade (estadual, em face da União; municipal, em face do Estado) ou porque é comum (todos têm o mesmo interesse) ou porque envolve tipologias, conceituações que, se particularizadas num âmbito autônomo, engendrariam conflitos ou dificuldades no intercâmbio nacional, constitui matéria de norma geral. (grifamos)

Note-se, pois, que o jurista considera insuficiente o critério lógico-formal para distinguir as normas gerais das normas ordinárias e recomenda a utilização de outros critérios para auxiliar o intérprete, entre esses a interpretação sistemática para aquilatar o interesse do ente federado.

De outra banda, conclusivo é o entendimento de Raul Machado Horta sobre normas gerais, segundo o qual são aquelas que não esgotam, por completo, determinado assunto. $\mathrm{Ou}$ melhor, são normas não exaustivas, normas incompletas, de modo a não esgotar na competência da União a matéria da legislação concorrente; ou em outros termos, essas normas gerais deverão tomar a forma de "lei quadro", uma moldura legislativa ${ }^{77}$. Assim, são tidas como normas gerais aquelas disposições que contém definições de expressões usadas pela legislação; firmam pressupostos, fundamentos, metas e diretrizes gerais para um sub-sistema regrado pelos entes federados; fixam prazos máximos e mínimos; definam proibições ou permissões, bem como estabeleçam exceções às regras constitucionais.

Em sede de competência concorrente, via de regra, as normas gerais são típicas leis nacionais, isto é, são válidas e eficazes para todo o território nacional, incidindo sobre todos os Estados e interagindo sobre as leis estaduais, bem como as municipais - típica forma de integração nacional - de sorte que condicionam a interpretação da matéria, conforme dispõe o $\S 4^{\circ}$ do art. 24 da CF, ao determinar que a superveniência de lei federal suspende a eficácia da lei estadual, no que lhe for contrário, pois transcendem o interesse do ente central, para fazer frente sobre toda a nação, daí serem tidas como nacionais.

\footnotetext{
${ }^{77}$ HORTA, 1993, p. 17-18.
} 
Assim, a nomenclatura apropriada a ser utilizada nos $\S 3^{\circ}$ e $\S 4^{\circ}$ do art. 24 deveria ser lei nacional, e não "lei federal", equívoco de redação do constituinte ${ }^{78}$.

Preleciona Cléber Otero que as normas gerais são leis nacionais, dirigidas, sem distinção, aos legisladores da União, dos Estados-membros, do Distrito Federal e dos Municípios, porém não poderão invadir o campo de competência determinado para cada um desses entes políticos ${ }^{79}$.

E mais, a própria sistemática da competência concorrente exige por imperativo lógico o condicionamento das normas particularizantes às gerais, de forma que se assenta uma hierarquia nos comandos ideológicos das normas estaduais e municipais, pois devem seguir os passos das normas gerais. No esteio desse raciocínio é o posicionamento de Ives Gandra Martins, que invoca Manoel Gonçalves Ferreira Filho:

Tenho para mim, nada obstante o argumento dos que assemelham a competência comum à concorrente, que há uma diferença de grau hierárquico, a saber: na competência, nenhum ente federativo está hierarquicamente subordinado, em sua ação, à atuação do outro, enquanto na competência concorrente, a da União prevalece sobre a dos Estados e a dos Estados sobre a dos Municípios.

Desta forma, embora concorrente, há uma precedência legislativa, no que concerne à legislação ordinária. ${ }^{80}$

No esteio desse raciocínio, o Supremo Tribunal Federal recentemente considerou inconstitucional em sede de liminar na Adin no 3.054, a Lei Estadual Paranaense $n^{\circ}$ 14.162/03 que vedava o ingresso, a comercialização ou o plantio de soja geneticamente modificada no Paraná, promovida pelo Governo do Mato Grosso do Sul que procurava exportar a soja matogrossense pelo porto de Paranaguá-PR, pois norma federal já disciplina a matéria, a título de normas gerais ${ }^{81}$, e estabelece uma série de preceitos gerais sobre o assunto sobrepostos e ignorados pela legislação paranaense. Assim, o Supremo considerou que uma vez presentes normas gerais da União, em sede de competência concorrente, sobre produção e consumo e a proteção ao meio ambiente, essas devem ser respeitadas em todo o território nacional, de sorte que as leis estaduais sobre o assunto não poderão contrastar a lei federal que confere a base

\footnotetext{
${ }^{78}$ Nesse sentido Cf. ROCHA, 1997, p. 249.

${ }^{79}$ OTERO, Cleber Sanfelice. A lei complementar como instrumento de realização de segurança jurídica. 2002. 174 f. Dissertação (Mestrado em Direito) - Instituição Toledo de Ensino de Bauru, Bauru, p. 144-149.

${ }^{80}$ BASTOS; MARTINS, 1993, p. 02-03.

${ }^{81}$ Lei Federal no 8.974, competência concorrente com arrimo no art. 24, V, da CF.
} 
estrutural sobre a matéria, mormente em face do intuito de exportação da soja pelo território paranaense, interesse de cunho nacional ${ }^{82}$.

Nesse sentido, conclui André Ramos Tavares que norma geral é aquela que admite ou veda determinada conduta no sentido de que, se determinada lei federal admitir certa prática, não caberá à lei estadual estabelecer o contrário; se determinada lei federal proibir certa prática, a lei estadual não poderá permiti-la ${ }^{83}$.

Contudo, fixada a premissa do assunto por normas gerais de cunho federal, os demais entes federados poderão lançar legislação que conceda maiores peculiaridades ao caso (e se já lançada continuará em vigor), como no caso da legislação concorrente em matéria de defesa do meio ambiente. Assim, se norma federal determinar a conservação de determinada percentagem vegetal em mata nativa para exploração da agricultura, admite-se ${ }^{84}$ que o Estadomembro poderá conceder maior proteção de percentual de proteção ambiental sobre área em recuperação erosiva, de sorte que ambas normas serão válidas, mas será eficaz aquela que conceda maior proteção ao bem jurídico tutelado - o meio ambiente. É justamente nesse viés que se projeta a tônica da competência concorrente, pois ambas estão direcionadas no mesmo sentido, a proteção da mata nativa; contudo, aplica-se em último caso a legislação estadual, pois consentânea ao sentido e diretriz da legislação federal, mas, por peculiaridade da região, firma proteção mais rigorosa ao bem protegido.

Como visto, a competência concorrente requer a densificação normativa, isto é, que a particularização das normas específicas fique por conta tanto dos Estados, do Distrito Federal, como também dos Municípios, desde que haja interesse local que legitime a atuação dos últimos, consoante demarca o artigo $30 \mathrm{da} \mathrm{CF}$, os quais se subordinam também à produção legislativa dos Estados nesta matéria.

Diz o parágrafo terceiro do art. 24: inexistindo lei federal sobre normas gerais, os Estados exercerão a competência legislativa plena, para atender as suas peculiaridades. Assim, ante a inexistência de lei federal, os Estados poderão produzir as normas gerais e as particulares preconizadas no rol do art. 24. Aquelas terão eficácia provisória, pois se suspenderão apenas naquilo que lhe for contrário com o advento de normas gerais da União,

\footnotetext{
${ }^{82} \mathrm{O}$ assunto será melhor explicitado na segunda parte dos trabalhos na análise de antinomias no âmbito da competência concorrente.

${ }^{83}$ TAVARES, 2008, p. 178.

${ }^{84}$ Salvo se tratar de normas gerais que firmam tratamento uniforme sobre determinado assunto, situação inteiramente diversa do exemplo mencionado.
} 
mas a nova lei somente regulará as relações futuras com efeito ex nunc. Frise-se, novamente, que as leis estaduais gerais não serão revogadas, mas apenas suspensas, diante da dicção do artigo $24, \S 4^{\circ}$, de sorte que, se revogadas as normas gerais da União, aquelas voltam a viger.

Insta consignar que o impulso original do constituinte de 1988, como já observado, foi justamente o alargamento da participação legislativa dos Estados-membros nas engrenagens do federalismo brasileiro erigido pela nova Carta Política, situação particularmente comemorada com a implementação da competência legislativa concorrente, como nota Raul Machado Horta ${ }^{85}$ logo após a promulgação da Constituição de 1988:

O quarto plano de repartição de competências é ocupado pela competência de legislação concorrente da União, dos Estados e do Distrito Federal (art. 24 - I até XVI, $\S 1^{\circ}, 2^{\circ}, 3^{\circ}$ e $4^{\circ}$ ).

Trata-se de inovação relevante, que supera os ensaios tímidos da competência supletiva ou complementar das Constituições Federais anteriores, conferindo autonomia material e formal à competência concorrente. (...)

A legislação concorrente, que amplia a competência legislativa dos Estados, retirando-a da indigência em que a deixou a pletória legislação federal no domínio dos poderes enumerados, se incumbirá do afeiçoamento da legislação estadual às peculiaridades locais, de forma a superar a uniformização simétrica da legislação federal.

A repartição concorrente cria outro ordenamento jurídico dentro do Estado Federal, o ordenamento misto, formado pela participação do titular do ordenamento central e dos titulares de ordenamentos parciais.

(...) É manifesta a importância desse tipo de legislação em federação continental, como a brasileira, marcada pela diferenciação entre grandes e pequenos Estados, entre Estados industrializados em fase de alto desenvolvimento e Estados agrários e de incipiente desenvolvimento industrial, entre Estados exportadores e Estados consumidores. Escapou ao constituinte a inclusão no domínio de legislação concorrente de alguns setores apropriados a essa atividade legislativa, como: o direito agrário, o direito e processo administrativo, o direito do trânsito, higiene e segurança do trabalho, regiões metropolitanas. A legislação concorrente, não obstante as omissões, alargará o domínio dos poderes reservados e certamente abrirá aos Estados um período de atividade legislativa profundamente diverso do período de retraimento dos poderes reservados, no qual vivem os Estados-membros, em contraste com a plenitude dominadora dos poderes enumerados da Federação.

Posto isso, imperativo lançar uma crítica observação política sobre o rumo que se tem firmado a interação da competência concorrente com o advento da legislação positivada pelos entes federados, onde se nota forças centralizadoras no âmbito da Federação, quer pela intensa utilização de normas federais para regrar os assuntos e muitas vezes desbordar das normas gerais para imiscuir-se em assuntos de maior detalhe, próprio da competência dos Estados-

\footnotetext{
${ }^{85}$ HORTA, 1993, p. 17-18.
} 
membros, quer pela tradição histórica do federalismo pátrio conjugar poderes ao ente central, quer ainda em face de certa complacência do Supremo Tribunal Federal para admitir tais normas como constitucionais ${ }^{86}$. Surge nessa conjuntura um desafio à autonomia legislativa dos Estados-membros, bem como um possível retorno ao vetusto centralismo de forças centrípetas no âmbito da Federação Brasileira, e como tal, um perigoso retrocesso ao federalismo pátrio.

Essa preocupação já fora prenotada por Anna Cândida da Cunha Ferraz no ano seguinte ao advento da Carta Política:

Essa nova fórmula de distribuição de poderes não tende, necessariamente, consoante tem sido apontado com certa frequiência, a fortalecer as unidades federadas ou aumentar o grau de descentralização política no Brasil. Na verdade pode ela ser vista como instrumento de centralização normativa, uma vez que a maioria das principais áreas do campo legislativo fica reservada à Federação, ainda que no âmbito restrito das "normas gerais". Para corroborar a afirmação, observem-se: o vasto elenco de matérias submetidas à "legislação de princípios" da União; a inclusão nesse elenco de matérias que dantes eram autonomamente regulamentadas pelos estados; a dificuldade prática de, em certos casos, fixar-se com clareza o limite do conteúdo das "normas gerais"; e a inevitável uniformização no tratamento de certas matérias, fato esse que nem sempre poderá ser superado pelas normas específicas para atender às diversidades regionais existentes no País ${ }^{87}$.

Essa previsão, infelizmente, vem sido constatada na prática, consoante observa Denise Vasques $^{88}$, ao dissertar sobre o tema e registrar que em um país de história e tradição centralizadoras - é bom lembrar - torna-se arriscado depositar expectativas na atuação legislativa dos Estados-membros; isto é, a tendência natural é que a União regule inteiramente (ou quase) as matérias, sob a alegação de que legisla sobre normas gerais.

Prossegue a estudiosa, já em sede de conclusão:

Analisamos julgados que cuidaram da constitucionalidade de leis estaduais em face dos $\S 1^{\circ}$ e $2^{\circ}$ do artigo 24 da Constituição Federal de 1988. Verificamos, em nossa pesquisa jurisprudencial, que o questionamento de leis estaduais ocorre com maior freqüência do que a impugnação de leis nacionais. Esse fato, por si só, revela características de nosso federalismo centralizador, quais sejam, a assunção de que o

\footnotetext{
${ }^{86}$ Também nesse sentido é o posicionamento de André Ramos Tavares (2008, p. 161-188). Analisou o autor 17 decisões do STF que deliberaram sobre a inconstitucionalidade de leis estaduais, cujo resultado apontou que 12 dessas são inconstitucionais, por afronta à competência legislativa da União, quer por terem atentado contra a competência privativa, quer por terem se imiscuído naquelas matérias tidas como normas gerais no âmbito do art. 24 da CF. Considerou, pois, o autor que a jurisprudência do STF tem demonstrado uma leitura pró-federal. Também é o posicionamento de Denise Vasques (2007, p. 182-183). A autora pontua que o Supremo Tribunal Federal não emprega um critério para uniformizar o uso das expressões suplementar (referente à competência do Estado-membro) nas suas decisões, utilizando-as indiscriminadamente.

${ }^{87}$ FERRAZ, 1989b, p. 70.

${ }^{88}$ VASQUES, 2007, p. 60.
} 
legislador nacional atua com maior respeito aos limites constitucionais do que o legislador estadual, o que não é necessariamente verdadeiro, e, ainda, a maior restrição sofrida pela atividade legislativa estadual se comparada à atividade legislativa da União.

Entre as conclusões extraídas do Capítulo V, destacamos, nesta ocasião, as mais importantes. Em primeiro lugar, constatamos a inexistência de evolução jurisprudencial entre o regime constitucional de 1967/69 e o de 1988. Vale dizer, o Supremo Tribunal Federal apresenta atualmente as mesmas razões e raciocínios fixados que quando julgava à luz da Constituição Federal de 1967/69. Quanto à concepção do Supremo a respeito das competências legislativas concorrentes da União e dos Estados-membros, mais especificamente, das normas gerais e da competência estadual suplementar, notamos tendência centralizadora em consonância com o entendimento do legislador nacional. (...)

A análise dos julgados permitiu também identificar que, para formar seu juízo a respeito da constitucionalidade ou da inconstitucionalidade de leis estaduais, o Supremo busca como respaldo o confronto entre leis infraconstitucionais. Isto é, o Tribunal toma conhecimento, em primeiro lugar, do quanto disposto nas leis nacionais e estaduais para, depois, contestá-las em face da Constituição Federal.

Por essas razões, concluímos que a atividade do Supremo Tribunal Federal, quanto à aplicação das regras de repartição vertical das competências legislativas, contribui para maior centralização de poderes. Em outras palavras, o Supremo alimenta a tendência centralizadora do nosso federalismo e participa ativamente do recrudescimento dos poderes da União.

Deveras, essa assertiva já fora até colocada em discussões no Supremo Tribunal Federal pelo Ministro Ricardo Lewandowski, na análise de normas federais frente à competência concorrente no julgamento da $\mathrm{ADI} \mathrm{n}^{\mathrm{o}} 3.645-9 / \mathrm{PR}$, conforme revela o Ministro:

\begin{abstract}
Dentro desse movimento pendular que caracteriza o federalismo brasileiro com momentos de grande concentração de poder ao nível da União, e outro de grande desconcentração em favor dos demais entes federativos, verifica-se que, paulatinamente, estamos caminhando, na verdade, para um Estado unitário descentralizado, haja vista as recentes reformas administrativas previdenciária, judiciária, tributária. Observa-se também, que, no âmbito da competência concorrente prevista no art. 24 da Magna Carta, cada vez mais esvaziada a competência dos Estados de legislar supletivamente, porque a União, quando legisla, esgota o assunto, não se limita a editar apenas normas gerais.
\end{abstract}

Justamente para atender a interpretação autêntica do constituinte e o espírito da Carta Política de 1988, que lança como cláusula pétrea o dogma do federalismo (art. 60, § $4^{\circ}$, I), há de se adotar interpretação conforme a Constituição para as normas federais que particularizam a seara regrada, qualificadas assim como específicas (e não gerais) para só serem válidas únicas e exclusivamente aos órgãos da União - entidade autônoma que compõe o Estado Federal. 
É justamente nesse viés interpretativo que se procurará expor a interpretação constitucional a ser tomada quando presente possíveis antinomias jurídicas entre os entes federados, a ser visto na segunda parte do trabalho, sem pretensão de esgotar o assunto dada a complexidade e desafiante natureza do tema.

Enfim, a competência concorrente consiste em refinada técnica de conjugação de competências em homenagem à dinâmica do Estado hodierno e a necessária integração da legislação nacional, sem perder de foco a preservação do regramento das peculiaridades inerentes a cada região, orquestrada pela autonomia política de cada ente federado. Busca-se, portanto, atingir a tônica do federalismo, alcançar a unidade sem prejuízo das diversidades regionais.

\subsection{Competências Materiais ou Legislativas Decorrentes}

Algumas linhas sobre as competências materiais dos entes federados serão apontadas, especialmente sobre as atribuições administrativas conferidas na Carta Republicana aos entes políticos para que esses desempenhem ou garantam o exercício de determinadas atividades detendo a titularidade do serviço e a responsabilidade para o desempenho de tais funções, que ora realizam por si só, ora delegam à iniciativa privada mediante concessão ou permissão (e passam a gerenciar ou regulamentar tais atividades).

O constituinte arrola, pois, tarefas a serem zeladas pelo ente federativo, através de condutas administrativas de coordenação, planejamento, fiscalização e fomento, para enfim garantir que determinadas atividades sejam efetivadas sob o controle da União, do Estado ou do Município - ao menos, sob a diretriz gerencial de tais entes.

Floriano Azevedo Marques Neto pontua que tais atividades estão insertas no campo próprio da regulação estatal realizada pelos entes federados, segundo a qual esses, por meio de intervenção estatal direta ou indireta, condicionam, normatizam ou incentivam a atividade econômica de modo a preservar a sua existência, assegurar seu equilíbrio ou atingir determinados objetivos como desiderato de uma política pública ${ }^{89}$

De tais obrigações materiais advêm as chamadas competências legislativas impróprias ou decorrentes, as quais surgem por via transversa, isto é, emanam da competência

\footnotetext{
${ }^{89}$ MARQUES NETO, Floriano Azevedo. A Nova Regulamentação dos Serviços Públicos. Revista Eletrônica de Direito Administrativo Econômico, $\mathrm{n}^{\circ}$ 01, fev. 2005b, Salvador.
} 
administrativa, da necessidade de regular os interesses que lhe são deferidos constitucionalmente. Nesse sentido leciona Anna Cândida da Cunha Ferraz:

embora se cogite, na espécie, de exercício de 'poder', de execução de atividade ou desempenho de encargo, as competências gerais não excluem ação normativa precedente, emanada da própria esfera de poder. Assim, por exemplo, a prestação pelo município, de serviços públicos de interesse local, inclusive o de transportes coletivos (art. 30, V), demandará, com certeza, legislação municipal disciplinadora dessa atividade local ${ }^{90}$.

Por sua vez, Luiz Alberto David Araújo complementa essa assertiva ao observar que das competências comuns (art. 23 da CF) surgem as chamadas competências concorrentes impróprias, pois essas têm lugar ante a necessidade de se dar alicerce legislativo para o exercício de uma competência comum, como, por exemplo, a determinação de proteger o meio ambiente e combater a poluição em qualquer de suas formas (art. 23, VI). Pondera, ainda, que as competências legislativas impróprias não têm no seu regime jurídico balizas quanto ao seu limite, ou seja, cada ordem federativa pode legislar de maneira integral sobre a matéria. A situação regulamentada, de sua vez, ficará submetida ao espectro regrativo das leis de todas as ordens da Federação ${ }^{91}$.

Assim, diante de tais imperativos materiais impostos aos entes federados, decorre a prerrogativa legislativa para regular suas atribuições, direitos e obrigações justamente para consecução de seus objetivos; enfim para firmar uma política pública da área objeto de sua competência material. Decorre daí a possibilidade da insurgência de conflitos legislativos, como a experiência demonstra, dada a multiplicidade de centros normativos que interagem tanto em nível federal, estadual, como municipal em assuntos convergentes. No capítulo seguinte tecer-se-á alguns apontamentos sobre tais conflitos e a interpretação para conciliá-los.

\subsubsection{Competência Material da União}

A repartição de competências é perfilhada diretamente na Constituição da República, tipologicamente situada na organização do Estado, Título III, cujo Capítulo II trata da União particularizada em vinte e cinco incisos do art. 21, que trata das competências materiais ou

\footnotetext{
${ }^{90}$ FERRAZ, 1989b, p. 65. No mesmo sentido, Cf. ALMEIDA, 2007, p. 68.

${ }^{91}$ ARAÚJO; NUNES JUNIOR, 2009, p. 274-275.
} 
executivas da União - atribuições de caráter executivo que a União desempenha por si, ou reserva para si o ônus de assegurar que tal atividade será posta à disposição da coletividade, mediante delegação ou descentralização dos serviços - em geral realizada mediante concessão, modalidade mais comum ultimamente.

Demonstra este longo desdobramento a múltipla dimensão dos poderes federais do Governo da União e a diversidade da matéria atribuída, sem contudo esgotá-las, segundo a seguinte classificação ${ }^{92}$ :

Poderes Soberanos, quando representa a própria Federação, art. 21, I, II, III, IV, VI, VII, XVII, quais sejam: manter relações com Estados estrangeiros e participar de organizações internacionais; declarar a guerra e celebrar a paz; assegurar a defesa nacional; permitir, nos casos previstos em lei complementar, que forças estrangeiras transitem pelo território nacional ou nele permaneçam temporariamente; autorizar $e$ fiscalizar a produção e o comércio de material bélico; emitir moeda; conceder anistia.

Poderes de Planejamento e Desenvolvimento, art. 21, VIII, IX, XVIII, XIX, XX e XXI, respectivamente: administrar as reservas cambiais do País e fiscalizar as operações de natureza financeira, especialmente as de crédito, câmbio e capitalização, bem como as de seguro e previdência privada; elaborar e executar planos nacionais e regionais de ordenação do território e de desenvolvimento econômico e social; planejar e promover a defesa permanente contra as calamidades públicas, especialmente as secas e as inundações. Instituir diretrizes para o desenvolvimento urbano, inclusive habitação, saneamento básico e transportes urbanos; estabelecer princípios e diretrizes para o sistema nacional de viação.

Poderes de Defesa do Estado e da Organização da Estrutura Federal, art. 21, V, XIII, XIV, XV, XXIV, XXII, quais sejam: decretar o estado de sítio, o estado de defesa e a intervenção federal; organizar e manter o Poder Judiciário, o Ministério Público e a Defensoria Pública do Distrito Federal e dos Territórios; organizar e manter a polícia civil, a polícia militar e o corpo de bombeiros militar do Distrito Federal, bem como prestar assistência financeira ao Distrito Federal para a execução de serviços públicos, por meio do fundo próprio (EC 19); organizar e manter os serviços oficiais de estatística, geografia,

\footnotetext{
${ }^{92}$ Inspirada, entre outros, em HORTA, 1993, p. 11-13.
} 
geologia, e cartografia de âmbito nacional; executar os serviços de polícia marítima, aeroportuária e de fronteiras (EC 19).

Poderes de Regulador dos Serviços Públicos e de Interesse Público, art. 21, X, XI, XII, a, b, c, d, e, f, XVI, XXIII, a, b, c; XXIV e XXV, respectivamente: manter o serviço postal e o correio aéreo nacional; explorar, diretamente ou mediante autorização, concessão ou permissão, os serviços de telecomunicações, nos termos da lei, que disporá sobre a organização dos serviços, a criação de um órgão regulador e outros aspectos institucionais (EC 8); explorar, diretamente ou mediante autorização, concessão ou permissão: a) os serviços de radiofusão sonora, e de sons e imagens; b) os serviços e instalações de energia elétrica e o aproveitamento energético dos cursos de água, em articulação com os Estados onde se situam os potenciais hidroenergéticos; c) a navegação aérea, aeroespacial e a infraestrutura aeroportuária; d) os serviços de transporte ferroviário e aquaviário entre portos brasileiros e fronteiras nacionais, ou que transponham os limites de Estado ou território; e) os serviços de transporte rodoviário interestadual e internacional de passageiros; $f$ ) os portos marítimos, fluviais e lacustres; exercer a classificação para efeito indicativo, de diversões públicas e de programas de rádio e televisão; explorar o serviços e instalações nucleares de qualquer natureza e exercer monopólio estatal sobre a pesquisa a lavra, o enriquecimento e reprocessamento, a industrialização e o comércio de minérios nucleares e seus derivados; organizar, manter e executar a inspeção do trabalho; estabelecer as áreas e as condições para o exercício da atividade de garimpagem, em forma associativa.

Eis o rol do art. 21 da CF que define as competências materiais da União, isto é, as atribuições de desempenhar determinadas atividades administrativas, cuja titularidade é privativa da União Federal em cotejo interpretativo com aquelas delineadas no art. 23 do texto constitucional. Por oportuno, registre-se que ainda cabe à União o desempenho de outras atividades descritas no texto constitucional além das descritas no rol do art. 21, eis que este rol não é exaustivo - como a competência para exploração de jazidas de petróleo e gás natural; a refinação e o transporte do petróleo nacional e importado (art. 176); a manutenção da seguridade social, bem como outras atribuições implícitas, próprias das tarefas de caráter unitário e soberano que a União firma na conjuntura da Federação, tanto no plano internacional como interno para articular soluções para tarefas que tenham interesse em mais de um dos Estados-membros. 
Nota-se que em linhas gerais a atividade administrativa da União volta-se para definir as linhas de desenvolvimento nacional, com nítida importância ao papel de planejamento e coordenação de políticas públicas, próprio do federalismo cooperativo, onde a União desenvolve a primeira fase no desdobramento das políticas públicas.

Como já se disse, da competência material decorre necessariamente a competência legislativa (imprópria) de titularidade do mesmo ente político; e no caso da competência concorrente administrativa, de tantos quantos entes têm incumbência da realizar a tarefa administrativa (art. 23 da CF).

Já quanto ao primeiro item da competência administrativa (art. 21, I,), vale registrar que somente a União representa a Federação no âmbito internacional, vez que somente ela é pessoa jurídica de Direito Internacional Público e faz às vezes da representação de todo o País, via tratados e convenções internacionais, atos que firmam prerrogativa legislativa internacional à Federação (na sua totalidade), como adiante se verá - pois serão apontados detalhes dessa competência, em capítulo próprio, diante da relevância do tema.

Do extenso rol de atribuições materiais da União Federal é imperativo destacar o crescente papel regulador do Estado na prestação de serviços públicos, derivado das complexas reivindicações da sociedade pós-moderna, cuja logística de atuação estatal traz nova feição ao próprio Estado. Rotulado outrora como Estado Liberal no séc. XIX e Estado Social no séc. XX, passa atualmente a ser nominado - à luz do novo papel do Estado na prestação dos serviços públicos, ou melhor, no orquestramento da prestação de serviços públicos - como Estado Regulador ${ }^{93}$.

A temática em apreço tem como pano de fundo o novo papel do Estado na prestação dos serviços públicos, atualmente, no gerenciamento da prestação de serviços públicos. O assunto interage diretamente na relação do Estado e sociedade e seu novo perfil de relacionamento. Em comparação às décadas anteriores, visualiza-se o crescimento da intervenção estatal mediante a regulação no domínio econômico (em sentido amplo) e o recrudescimento da atuação direta estatal. Essa nova perspectiva é bem definida por Marco Vilena Souto ${ }^{94}$ :

\footnotetext{
${ }^{93}$ Sobre o tema Cf. SAMPAIO, Gustavo Castro. O Estado Regulador. Dissertação (Mestrado em Direito do Estado) - Faculdade de Direito da Universidade de São Paulo, São Paulo, 2007.

${ }^{94}$ SOUTO, Marco Vilena. Desestatização, Privatização, Concessões, Terceirização e Regulação. $4{ }^{\text {a }}$ Ed. Rio de Janeiro: Lúmen Juris, 2001, p. 7.
} 
Os programas de desestatização capitaneados pelos processos de privatizações $e$ concessões e liquidação de empresas, buscam corrigir tais distorções, repensando o papel do Estado e sua estrutura. Assume ainda, essencial relevância a função de fomento, pela qual o Estado incentiva os particulares a desenvolverem razões de interesse público ao invés dele próprio incorporar estruturas à Administração para empreendê-las. É a substituição do Estado do Bem-Estar, pelo Estado instrumento, afinal, o Estado moderno é aquele que viabiliza o adequado atendimento dos interesses da sociedade, mas não aquele que, necessariamente, os presta diretamente.

Esse novo perfil estatal adveio da conformação dialética que interage na relação Estado versus sociedade, sob o pálio da globalização ${ }^{95}$, cujas forças impeliram as mudanças jurídicas daí decorrentes, quais sejam, a crescente interação econômica com o direito, a relativização das fronteiras do direito público e do privado e a participação de agentes econômicos na prestação de serviços públicos. Fiel ao caráter programático e principiológico, a Constituição de 1988, permite evolução interpretativa nesse mesmo sentido - decorrente do papel ativo do intérprete na valoração de conceitos abertos.

Nessa ótica, o mercado e as forças econômicas internacionais caminham para a prestação de serviços com investimentos proporcionais às novas exigências sociais da sociedade pós-moderna, influxo que determinou o remanejamento das estruturas econômicas ${ }^{96}$ do Estado, então atuante diretamente na economia - cuja crise fiscal do Estado Social conduziu a esse novo modelo - para firmar atuação reguladora e estrutural das forças de mercado. Surge daí a nova versão do Estado hodierno, cunhado como Estado Regulador, frente à pós-moderna intervenção do Estado na economia, fazendo as vezes de um estrategista - conforme retrata o publicista francês Chevallier ${ }^{97}$, ao abordar os novos tempos e o papel estatal:

\begin{abstract}
(...) a intervenção reguladora do Estado é indispensável: a crescente complexidade dos circuitos econômicos, as mutações tecnológicas, a sofisticação dos produtos financeiros, a mundialização das trocas, mas também a crescente pressão dos poderes econômicos cujo poderio é reforçado pela mundialização, impõem a criação de instâncias capazes, fixar determinadas regras do jogo, de fazer prevalecer certas disciplinas, de proteger determinados interesses. O Estado mantém, por outro lado, as funções de auxiliar do mercado, ajudando as empresas em dificuldades ou setores de ponta, bem como corrigindo os desequilíbrios territoriais causados pela lógica puramente mercantil.
\end{abstract}

\footnotetext{
95 Fenômeno intensificado pelas regras gerais de livre comércio (GATT) - que impõem como requisito para
obtenção de recursos externos o fim das regras de proteção de mercado, para que todos os agentes econômicos
possam ter acesso ao mercado (ARAG ÃO, Alexandre. Direito dos Serviços Públicos. Rio de Janeiro: Forense,

95 Fenômeno intensificado pelas regras gerais de livre comércio (GATT) - que impõem como requisito para
obtenção de recursos externos o fim das regras de proteção de mercado, para que todos os agentes econômicos
possam ter acesso ao mercado (ARAGÃO, Alexandre. Direito dos Serviços Públicos. Rio de Janeiro: Forense,

95 Fenômeno intensificado pelas regras gerais de livre comércio (GATT) - que impõem como requisito para
obtenção de recursos externos o fim das regras de proteção de mercado, para que todos os agentes econômicos
possam ter acesso ao mercado (ARAGÃO, Alexandre. Direito dos Serviços Públicos. Rio de Janeiro: Forense, 2007, p. 47).

${ }^{96} \mathrm{Na}$ esteira das vozes dos economistas de Chicago, cuja maior expressão foi Milton Friedman. ${ }^{97}$ CHEVALLIER apud ARAGÃO, 2007, p. 49.
} 
Deveras, o contexto nacional ratifica esse movimento, onde o Estado passa a atuar como regulador da prestação do serviço público e não mais como prestador original, conforme se extrai do movimento de desestatização, na nova redação firmada pela EC no 8/95 ao art. 21, $\mathrm{XI}$ - pois a redação original determinava que a atuação no mercado de telefonia era restrito às empresas estatais.

Emerge daí as principais características que marcam esse novo perfil estatal, quais sejam, a mudança do modo de atuação do Estado da direta pela indireta; os objetivos da regulação, que outrora restrito à correção de falhas de mercado, atualmente voltam-se para concretização de políticas públicas; supera-se um paradigma de normatização estático para mecanismos mais dinâmicos.

Floriano de Azevedo Marques Neto ${ }^{98}$ complementa essas novas características: i) separação entre o operador estatal e o ente encarregado da regulação do respectivo setor e ii) a admissão do setor regulado da existência de operadores privados competindo com operador público (introdução do conceito de competição em setores sujeitos à intervenção estatal direta), o que leva alguns autores a caracterizar essa nova regulação como 'regulação para competição'.

A função regulatória tem como característica fundamental seu caráter técnico e especializado das agências - mas não político - justamente para conferir concretude às decisões de natureza política. Contudo, sua função normativa é restrita ao setor que regulamenta; sua função normativa visa interpretar, conceituar e explicitar conceitos jurídicos indeterminados contidos em lei, sem inovar ineditamente o ordenamento jurídico. Sua função volta-se para concretizar princípios, quadro e conceitos standards, próprios da atividade técnica.

A Constituição Federal expressamente reconhece a ANATEL e a ANP como órgãos reguladores, como se extrai dos arts. $21, \mathrm{XI}$, e $177, \S 2^{\circ}$, III, de sorte que se deve reconhecer a sua função normativa, tomada à luz do princípio da legalidade em sentido amplo (distinto da reserva legal) previsto no artigo $5^{\circ}$, II, isto é, de que ninguém é obrigado a fazer ou deixar de

\footnotetext{
${ }^{98}$ MARQUES NETO, Floriano A. As agências reguladoras independentes: fundamentos e seu regime jurídico. Belo Horizonte: Fórum, 2005a, p. 30-31.
} 
fazer alguma coisa senão em virtude da ação normativa do Estado, consoante pontua Sebastião Tojal $^{99}$.

E na eclosão de eventuais conflitos ou antinomias jurídicas entre a função regulatória das Agências - qualquer que seja - e a lei formal, essa prevalece, pois representa o veículo por excelência da centralidade política da produção normativa, dada a representatividade ínsita do Poder Legislativo. Advirta-se que a obediência à lei não exclui a possibilidade de edição de ato normativo editado sem sua intermediação, com o intuito de assegurar a eficácia da Constituição, obviamente respeitado o campo da reserva legal ${ }^{100}$.

Corroborado a essa assertiva, segue o posicionamento do STF no julgamento ADI-MC 1668 - DF, ao analisar preceito legal referente a atribuição da ANATEL no art. 19, X, da Lei 9.472/97, in verbis: "expedir normas e padrões a serem cumpridos pelas prestadoras de serviços de telecomunicações quanto aos equipamentos que utilizarem”, cuja decisão conferiu interpretação conforme a Constituição, nos seguintes termos:

[...] quanto aos incisos IV e X, do art. 19, sem redução de texto, dar-lhes interpretação conforme a Constituição Federal, com o objetivo de fixar exegese segundo a qual a competência da Agência Nacional de Telecomunicações para expedir normas subordina-se aos preceitos legais e regulamentares que regem outorga, prestação e fruição dos serviços de telecomunicações no regime público e no regime privado. (Relator: Min. Marco Aurélio. Julgamento: 20/08/1998. Órgão Julgador: Tribunal Pleno. Publicação: DJ de 16-04-2004, p. 52 - grifei).

Na segunda parte do trabalho algumas questões serão abordadas quanto à interação legislativa dos entes federados em cotejo à função regulatória dessas agências; e o posicionamento do Supremo Tribunal Federal sobre essas interações.

\subsubsection{Competência Material Dos Estados e do Distrito Federal}

A técnica utilizada pelo constituinte para expressar as competências materiais dos Estados-membros seguiu o mesmo perfil das competências legislativas perfilhadas ao Estado: não as menciona expressamente como faz com as da União, mas reserva a contingência das

\footnotetext{
99 TOJAL, Sebastião. Controle Judicial da Atividade Normativa das Agências Reguladoras. In: MORAES, Alexandre (coord.) Agências Reguladoras. São Paulo: Atlas, 2002, p. 162-170.

${ }^{100}$ MOTTA, Fabrício Macedo. A função normativa da Administração Pública Brasileira. Tese (Doutorado em Direito do Estado) - Faculdade de Direito da Universidade de São Paulo, São Paulo, 2007, p. 106.
} 
demais prerrogativas não conferidas à União e que não se cuidam de interesse local (essas próprias do Município).

Ressalva, no entanto, aos Estados a competência privativa de explorar os serviços locais de gás canalizado, ex vi $\mathrm{o} \S 2^{\circ}$ do art. 25 , na redação da $\mathrm{EC} \mathrm{n}^{\circ} 05$. Contudo, cabe à União o monopólio de pesquisa e a lavra das jazidas de gás natural. Assim, nesse contexto, a competência estadual restringe-se à execução da distribuição de gás e seu respectivo regramento; cuida-se, pois, de regra clara de competência que o constituinte conferiu aos Estados, justamente para não confundi-la com atribuições de interesse municipal, dado o interesse tipicamente local.

$\mathrm{O}$ artigo $25, \S 1^{o}$, da Constituição Federal expressa a chamada competência remanescente dos Estados-membros. Da mesma forma que as competências legislativas, também na seara das competências administrativas, o constituinte utilizou-se da técnica remanescente para delinear as atribuições dos Estados-membros, pois arrolou expressamente as competências da União e pontuou as competências dos Municípios; aos Estados relegou as competências remanescentes.

Dada a compressão das atribuições de competências entre os demais entes federados, remanesce restrito o campo de competências privativas materiais aos Estados. Nesse sentido observa Christina Pedreira que no processo de descentralização das decisões políticas, os Estados-membros ficaram bastante limitados em suas competências, pois suas atribuições se resumem àquelas que não competem à União e, ainda, que não podem ser cumpridas pelos Municípios. Complementa que cabe aos Estados a decisiva tarefa de influir nos rumos da municipalização das políticas públicas, para assim compensar as adversidades locais ${ }^{101}$.

Justamente em razão dessa situação, o princípio geral de interpretação que reina aqui aponta para a diretriz de impedir restrições às competências dos Estados em reverência à autonomia administrativa e legislativa dos entes federados, sua capacidade de autogoverno e auto-organização, salvo a atribuição expressamente ressalvada aos demais entes federados observação essa melhor explicitada na segunda parte do trabalho.

\footnotetext{
${ }^{101}$ PEDREIRA, Christina Almeida. Instrumentos legítimos à implementação das competências constitucionais administrativas comuns. Revista Brasileira de Estudos Constitucionais, Belo Horizonte, ano 2, n. 6, abr/jun. 2008, p. 35.
} 
Essa é a linha hermenêutica do controle de constitucionalidade dessas normas, como já se pronunciou o Supremo Tribunal Federal em diversas ocasiões ${ }^{102}$, seja no controle incidental ou no concentrado de constitucionalidade, ciente da atribuição de competência remanescente aos Estados-membros, de forma a pronunciar a inconstitucionalidade de normas estaduais tão somente quando essas efetivamente conspurcarem os princípios diretrizes diretamente inscritos na Constituição Federal.

A competência administrativa do Estado-membro é delineada também pelo princípio da predominância do interesse da matéria que norteia a repartição de competências entre as entidades componentes do Estado Federal, de sorte que aos Estados-membros são reservadas as competências de interesse regional, e que não estejam arroladas entre as atribuições da União.

De qualquer sorte, o operador do Direito deve ter em mente que as tensões do federalismo contemporâneo, situadas basicamente entre a exigência da atuação uniformizada e harmônica de todos os entes federados e o pluralismo federal, são resolvidas em boa parte por meio da colaboração e atuação conjunta das diversas instâncias federais ${ }^{103}$. Justamente nesse viés, o constituinte admitiu a criação e regulamentação de mecanismos operacionais que visam à concretização dos objetivos da Nação, em homenagem ao federalismo cooperativo, como é o caso das regiões metropolitanas, aglomerações urbanas e microrregiões.

A Constituição Federal outorgou aos Estados a prerrogativa de instituir mediante lei complementar regiões metropolitanas, aglomerações urbanas e microrregiões, constituídas por agrupamentos de municípios limítrofes, para integrar a organização, o planejamento e a execução de funções públicas de interesse comum, nos termos do art. $25, \S 3^{0^{104}}$.

Lei complementar estadual deverá conter normas capazes de implementar a política de integração regional para efetivamente tutelar o interesse comum. A integração é compulsória, mas deverá firmar a participação equânime dos entes envolvidos, pois se cuida de gestão conjunta de política pública entre os entes envolvidos e o Estado - sem que esse tome para si a prerrogativa da titularidade do serviço público, conforme explicitado abaixo.

\footnotetext{
${ }^{102}$ Como fora o caso da regulamentação da questão de turismo prevista no Decreto Paulista $\mathrm{n}^{\circ} 29.912 / 89$, relativa ao fretamento de ônibus de turismo, onde o aresto judicial pugnou pela inexistência de invasão de competência legislativa às questões de trânsito, na forma do RE no $201.865-\mathrm{SP}$, adiante explicitado.

${ }^{103}$ BERCOVICI, 2004, p. 61.

${ }^{104}$ Os Estados poderão, mediante lei complementar, instituir regiões metropolitanas, aglomerações urbanas e microrregiões, constituídas por agrupamentos de municípios limítrofes, para integrar a organização, o planejamento e a execução de funções públicas de interesse comum.
} 
Como se vê, o constituinte preocupou-se com a peculiaridade das regiões metropolitanas e expressamente positivou forma de atuação conjunta de gestão pública para a solução de problemas públicos comuns, entre esses podemos ilustrar a distribuição de água e esgoto, o tratamento do lixo, entre outras atribuições de interesse homogêneo para a região metropolitana, as aglomerações urbanas e microrregiões.

José Afonso da Silva ${ }^{105}$ diferencia os referidos agrupamentos municipais: Região Metropolitana constitui-se de um conjunto de Municípios cujas sedes se unem com certa continuidade urbana em torno de um Município pólo. Microrregiões formam-se de grupos de Municípios limítrofes com certa homogeneidade e problemas administrativos comuns, cujas sedes não sejam unidas por continuidade. Aglomerados urbanos carecem de conceituação, mas, de logo, se percebe que se trata de áreas urbanas, sem um pólo de atração urbana, quer tais áreas sejam cidades sedes dos Municípios, como na baixada santista (em São Paulo), ou não.

Deveras, somente através de efetiva integração ter-se-á política comum capaz de gerir os interesses regionais do aglomerado urbano, cujas razões de ordem técnica, ambiental e geográfica ditam essa orientação, de sorte que é compulsória a integração regional aos municípios envolvidos, sob pena de fazer tabula rasa ao planejamento e execução regional perquirida pelo constituinte e a própria exequibilidade do plano de ação aos interesses inerentes à conurbação regional.

Nesse sentido, leciona Alaôr Caffé Alves ${ }^{106}$ :

Pela função da referida lei complementar [que institui agrupamento de municípios], deduz-se que tais regiões deverão ter tratamento constitucional a nível do Estado, perfazendo as bases institucionais de sua criação e funcionamento em face da existência de municípios delas integrantes. Quer dizer também que, uma vez constituídas por lei complementar, a integração dos municípios será compulsória para o efeito de realização das funções públicas de interesse comum, não podendo o ente local subtrair-se à figura regional, ficando sujeito às condições estabelecidas a nível regional para realizar aquelas funções públicas de interesse comum. Esta peculiaridade, singular em nosso direito, define os limites da autonomia municipal no âmbito urbano-regional metropolitano.

\footnotetext{
105 SILVA, 2006, p. 649.

${ }^{106}$ ALVES, Alaôr Caffé. Regiões metropolitanas, aglomerações urbanas e microrregiões: novas dimensões constitucionais da organização do Estado brasileiro. Revista de Direito Ambiental, São Paulo, v. 6, n. 21, p. 5782, jan./mar. 2001, p. 57, 61-62.
} 
Ressalta-se que o voto do Ministro Gilmar Mendes nas ADINs 1842 e $2077^{107}$ esclarece o caráter compulsório da participação dos municípios em regiões metropolitanas, microrregiões e aglomerações urbanas.

A região metropolitana é, pois, um mecanismo de gestão compartilhada entre os entes federados. Dada a natureza jurídica do instituto não admitir que o Estado ou o Município regente tome para si a titularidade dos serviços públicos inerentes ao conglomerado urbano, consoante os votos firmados nas ADIN no 1842 e 2077, ainda em fase de julgamento pelo Supremo Tribunal Federal - que declaram inconstitucionais artigos das leis estaduais ${ }^{108}$ que atribuem ao Estado a função de organização e titularidade dos serviços de saneamento básico em regiões metropolitanas.

É o que se extrai dos votos dos Ministros Joaquim Barbosa e Gilmar Mendes que defendem a tese de compartilhamento entre Estado e Município na criação de organismo regional responsável pelo poder concedente para os serviços de saneamento básico. Na visão desses Ministros a titularidade do exercício das funções públicas de interesse comum passa para a nova entidade político-territorial-administrativa, de caráter intergovernamental, que nasce em consequiência da criação da região metropolitana.

Vale transcrever as últimas assertivas do Ministro Gilmar Mendes no decorrer do voto ADIN no 1.842-5:

\footnotetext{
${ }^{107}$ ADI 1841/RJ, Rel. Min. Carlos Velloso, DJ 20.9.2002.

${ }^{108}$ Entre os artigos declarados inconstitucionais nos votos em andamento da Lei Estadual (RJ) Complementar $n^{\circ}$ 87 são os seguintes:

Art. $6^{\circ}$ - Compete ao Estado:

I - a realização do planejamento integrado da Região Metropolitana e o estabelecimento de normas para o seu cumprimento e controle;

II - a unificação, sempre que possível, da execução dos serviços comuns de interesse metropolitano, na forma do parágrafo único do artigo $5^{\circ}$ desta lei;

(...)

IV - o estabelecimento, através da Agência Reguladora dos Serviços Públicos Concedidos do Estado do Rio de Janeiro - ASEP/RJ, de normas gerais sobre a execução dos serviços comuns de interesse metropolitano e o seu cumprimento e controle;

V - exercer as funções relativas à elaboração e supervisão da execução dos planos, programas e projetos relacionados às funções públicas e serviços de interesse comum, consubstanciado no Plano Diretor Metropolitano;

(...)

Art. $7^{\circ}$ - Ao Estado compete, ainda, conforme o disposto no artigo 242 da Constituição do Estado do Rio de Janeiro, organizar e prestar, diretamente ou sob o regime de concessão ou permissão, os serviços públicos de interesse metropolitano, previstos nos incisos II, III, IV e V do artigo $3^{\circ}$ desta lei, e, ainda, na hipótese em que, abrangendo a dois ou mais municípios integrantes ou não de regiões metropolitanas, aglomerações urbanas e microrregiões, a prestação dos serviços for realizada através de sistemas integrados entre si, bem como a fixação das respectivas tarifas, obedecidos os preceitos estabelecidos no artigo 175 da Constituição Federal e demais normas aplicáveis à espécie.
} 


\section{(7) Conclusão}

Nesses termos, entendo que o serviço de saneamento básico - no âmbito de regiões metropolitanas, microrregiões e aglomerados urbanos - constitui interesse coletivo que não pode estar subordinado à direção de único ente, mas deve ser planejado e executado de acordo com decisões colegiadas em que participem tanto os municípios compreendidos como o estado federado.

Portanto, nesses casos, o poder concedente do serviço de saneamento básico nem permanece fracionado entre os municípios, nem é transferido para o estado federado, mas deve ser dirigido por estrutura colegiada - instituída por meio da lei complementar estadual que cria o agrupamento de comunidades locais - em que a vontade de um único ente não seja imposta a todos os demais entes políticos participantes.

Esta estrutura colegiada deve regular o serviço de saneamento básico de forma a dar viabilidade técnica e econômica ao adequado atendimento do interesse coletivo.

Ressalte-se que a mencionada estrutura colegiada pode ser implementada tanto por acordo, mediante convênios, quanto de forma vinculada, na instituição dos agrupamentos de municípios. Ademais, a instituição de agências reguladoras pode se provar como forma bastante eficiente de estabelecer padrão técnico na prestação e concessão coletivas do serviço de saneamento básico

Ante o exposto, julgo prejudicada a ação quanto ao Dec. $n^{\circ} 24.631 / 1998 / R J$ e aos arts. $1^{\circ}$, caput e $\S 1^{\circ} ; 2^{o}$, caput; $4^{o}$, caput e incisos I a VII; 11, caput e incisos I a VI; e 12 da LC 87/1997/RJ, isto é, em menor extensão que o voto do Relator, Min. Maurício Corrêa, que entendeu prejudicados adicionalmente os parágrafos $1^{\circ}$ e $2^{o}$ do art. $4^{\circ}$; e $1^{\circ}$ e $2^{\circ}$ do art. 11 da LC 87/1997/RJ.

Ademais, julgo procedente a ação direta, para declarar a inconstitucionalidade da expressão "a ser submetido à Assembléia Legislativa" do inciso I do art. $5^{\circ}$, além do parágrafo $2^{\circ}$ do art. $4^{\circ}$; do parágrafo único do art. $5^{\circ}$; dos incisos I, II, IV e V do art. $6^{o}$; do art. $7^{\circ}$; do art. 10, e do parágrafo $2^{\circ}$ do art. 11 todos da LC 87/1997/RJ, bem como dos 11 a 21 da Lei $n^{\circ}$ 2.869/1997/RJ, modulando os efeitos da declaração para que só tenha eficácia a partir de 24 meses após a conclusão do presente julgamento.

Esclareça-se, ainda, que o voto reporta-se ao sistema de consórcios preconizado pela gestão associada de serviços públicos preconizada pelo art. 241 da $\mathrm{CF}^{109}$, cuja distinção é que nesse a adesão é livre aos entes envolvidos, seja ou não região metropolitana.

Assim, eventuais conflitos legislativos devem, até por desiderato constitucional, levar em consideração os consórcios já estabelecidos entre os entes políticos, cuja força jurígena é de ato jurídico perfeito ao menos durante sua vigência.

\footnotetext{
${ }^{109}$ Art. 241. A União, os Estados, o Distrito Federal e os Municípios disciplinarão por meio de lei os consórcios públicos e os convênios de cooperação entre os entes federados, autorizando a gestão associada de serviços públicos, bem como a transferência total ou parcial de encargos, serviços, pessoal e bens essenciais à continuidade dos serviços transferidos. (Cf. ainda Lei 11.107/05).
} 
Oxalá as Administrações consigam superar suas divergências e alcançar a prestação do serviço público com maior excelência pela gestão compartilhada de atribuições administrativas, caminho para atingir objetivo fundamental da República, o desenvolvimento nacional.

De outra banda, esclareça-se que a competência legislativa sobre saneamento básico é comum à União, a Estados e aos Municípios - CF, art. 23, IX. Nesse viés, a Lei Federal no $11.445 / 2007$ fixou as diretrizes gerais sobre o saneamento básico, ao passo que os demais entes federados deverão seguir tais preceitos, mas ainda poderão detalhar normativamente peculiaridades próprias à sua geografia local e respectiva escala habitacional.

Por derradeiro, frise-se que a criação, a incorporação, a fusão e o desmembramento de Municípios ${ }^{110}$, far-se-ão por lei estadual, dentro do período determinado por lei complementar federal, e dependerão de consulta prévia, mediante plebiscito, às populações dos Municípios envolvidos, após divulgação dos Estudos de Viabilidade Municipal, apresentados e publicados na forma da lei $\left(\mathrm{CF}\right.$, art. $\left.18, \S 4^{\circ}\right)$.

Quanto ao Distrito Federal é necessário repetir que esse ente congrega tanto as competências materiais próprias do Estado-membro, como a dos Municípios, de sorte que a ocorrência de possíveis conflitos só sucederá com a União.

\subsubsection{Competência Material dos Municípios}

$\mathrm{Na}$ mesma linha delineada para as competências legislativas, também nas atribuições materiais o Município se incumbe do trato das questões de interesse local, entre essas os serviços públicos que lhe são próprios. Assim, todos os assuntos que dizem respeito unicamente à comuna, ao seu autogoverno e autoadministração, são geridos e executados pelo próprio Município, apanágio de sua autonomia constitucional.

A questão do interesse local há de ser perquirida pelo interesse predominante no caso, pois, como é sabido, raramente um interesse é exclusivo de um ente federado, tanto porque reflexamente sempre incide no interesse de outro ente federado direta ou indiretamente.

\footnotetext{
${ }^{110}$ Questão que merece apreciação crítica é a acirrada proliferação dos municípios. - há no País mais de cinco mil entes federados - e o constituinte houve por bem restringir a criação de um Município. Registre-se que há de exigir critérios objetivos de viabilidade financeira do futuro Município, fixados em sede de Lei Complementar Federal ou Estadual, em prol de um Federalismo saudável, imune aos conchavos políticos regionais que ocasionam uma pseudo-autonomia municipal subsidiada pelos demais entes políticos, em descompasso com o interesse público de envergadura nacional.
} 
Portanto, interesse local não significa interesse exclusivo, mas sim predominante. Vê-se, pois, que a análise do interesse local deve ser realizada de acordo com as circunstâncias concretas em apreço, os serviços disponibilizados e as disposições da Lei Orgânica do Município.

Diante do conceito normativo-chave expresso na Constituição Federal para firmar a competência municipal, tem-se como presumido que nem todas as competências próprias do Município se encontram expressamente arroladas na Constituição, cabendo ao intérprete e à perspicácia do legislador orgânico formular o regramento fundamental das atividades do Município.

Nesse sentido leciona Pedro Serrano ao anotar que justamente em razão da volatilidade da conceituação de interesse local, nem sempre se poderá, com exatidão, estabelecer um conceito fixo, pois a definição do interesse deverá ser avaliada de acordo com a situação fática $^{111}$.

De qualquer sorte, a Constituição Federal explicita algumas competências materiais dos Municípios, nos termos do art. 30. Entre esses, arrecadar os tributos de sua competência e aplicar suas rendas; criar, organizar e suprimir distritos, observada a legislação estadual; organizar e prestar, diretamente ou sob o regime de concessão ou permissão, os serviços públicos de interesse local, incluído o de transporte coletivo; manter, com a cooperação técnica e financeira da União e do Estado, programas de educação infantil e de ensino fundamental (EC 53); prestar, com a cooperação técnica e financeira da União e do Estado, serviços de atendimento à saúde da população; promover, no que couber, adequado ordenamento territorial, mediante planejamento e controle do uso, do parcelamento e da ocupação do solo urbano.

Como se nota, em boa parte das atribuições municipais há interações com diretrizes legislativas dos demais entes federados, tal como na saúde e no ensino fundamental.

Contudo, deve-se notar que nas atribuições afeitas ao interesse local, como na promoção do ordenamento territorial, obedecidas as diretrizes gerais dos demais entes federados, caberá ao Município definir sua política de desenvolvimento urbano, conforme seus interesses e peculiaridades ínsitas à Comuna, devidamente regulamentadas no plano Diretor.

\footnotetext{
111 SERRANO, Pedro Estevam Alves Pinto. Região Metropolitana e seu regime constitucional. São Paulo: Editora Verbatim, 2009, p. 113.
} 


\subsubsection{Competência Material Comum dos Entes Federados}

A lógica do federalismo cooperativo funda-se na cooperação mútua dos entes federados para melhor desempenho das tarefas de interesse comum, conforme orientação e coordenação do Poder Central, através de um entrelaçamento e interdependência entre os níveis de governo em prol do interesse do cidadão e do equilíbrio de forças da Federação. Esse é o mote diretor das competências administrativas comuns aos três entes de nossa Federação, delineado no art. 23 da Constituição Federal.

Christina Pedreira observa que no desenrolar das atividades comuns aos entes federados, tal como capitulado no art. 23 da CF, o Poder Público cumpre funções de forma vertical, cabendo à União definir as linhas de desenvolvimento nacional; e horizontal, cabendo simultaneamente aos entes federados a definição, entre si, dos instrumentos operacionais, por meio dos quais implementarão as tarefas comuns ${ }^{112}$.

O ponto essencial das competências administrativas comuns é justamente a diretriz do federalismo cooperativo, a cooperação entre os entes federados para o desempenho racional de atividades de responsabilidade comum. E para operacionalização de serviços conjuntos aos entes federados é necessário traçar políticas públicas mínimas para a definição conjunta do planejamento para a promoção do desenvolvimento nacional.

Diante da ausência da positivação da lei complementar estipulada no parágrafo único do art. 23, os entes federados deverão por si - através de política articulada, delineada em acordos, compromissos ou convênios - efetivar o desenvolvimento das tarefas de atribuição comum, baseado no planejamento e na colaboração recíproca.

Essa a orientação que vige no momento, até porque a alteração da redação do parágrafo único do art. $23\left(\mathrm{EC}^{\circ} 52\right)$ determinou que leis complementares fixarão normas para cooperação entre os entes federados, tendo em vista o equilíbrio do desenvolvimento e do bem-estar em âmbito nacional. Vê-se, portanto, que múltiplas leis complementares, todas provindas da União, estabelecerão em diferentes campos, forma de cooperação interfederativa de modo distinto para cada âmbito administrativo - como já ocorre no âmbito da saúde e da educação.

Contudo, as mencionadas leis complementares ainda não foram positivadas. Assim, o acionamento de mecanismos que efetivem a cooperação administrativa para a execução das

\footnotetext{
${ }^{112}$ PEDREIRA, 2008, p. 23.
} 
tarefas comuns aos entes federados é medida que se impõe, seja através do acordo administrativo firmado em convênios ou protocolos, seja através de legislação decorrente de tais comandos constitucionais.

Christina Pedreira endossa esse posicionamento ao expressar raciocínio correlato à dinâmica das competências legislativas decorrentes na regulação das tarefas comuns e a elasticidade inerente ao sistema. Pondera que é próprio do federalismo de cooperação a inexistência de demarcação nítida de competências entre os Governos central e periféricos. Isso se vê na inscrição das chamadas competências comuns e concorrentes entre os entes federados. O fato que, sendo numa ou noutra competência, a solução quanto à definição de responsabilidades só será possível por meio de colaboração recíproca ${ }^{113}$.

Note-se, entretanto, que no decorrer das atividades comuns aos entes federados há certa coesão com o rol das competências concorrentes: como na proteção de documentos públicos e outros bens de valor histórico, artístico e cultural (art. 23, III e IV) há sintonia com a disposição do art. 24, VII e VIII da CF; o mesmo se aplica quanto à obrigação de facilitação de acesso à cultura, educação e ciência (art. 23, V) com a competência legislativa do art. 24, IX, da CF; idem para a assistência à saúde e proteção aos portadores de deficiência (art. 23, II) a legislação concorrente de integração social dos deficientes (art. 24, XIV); na proteção ao meio ambiente e na preservação da fauna e flora (art. 23, VI e VII) com a legislação sobre floresta e conservação da natureza (art. 24, VI).

Logo, no caso de conflito legislativo entre essas matérias, deve-se seguir o norte dos apontamentos próprios à competência legislativa concorrente. Contudo, o intérprete deve ter como diretriz que, no âmbito das competências comuns, a cooperação é o elemento central que gravita todas as engrenagens de competências e atribuições dos entes federados. Como já se apontou, a coordenação está para as competências legislativas concorrentes; assim como a cooperação está para as competências comuns.

Logo, nas competências comuns, todos os entes da Federação devem colaborar para a execução das tarefas determinadas pela Constituição. E mais: não existindo supremacia de nenhuma das esferas na execução destas tarefas, as responsabilidades também são comuns,

\footnotetext{
${ }^{113}$ PEDREIRA, 2008, p. 25.
} 
não podendo nenhum dos entes da Federação se eximir de implementá-las, pois o custo político recai sobre todas as esferas do governo ${ }^{114}$.

Destaca-se, assim, a cooperação como elemento nuclear aos entes federados no âmbito das competências administrativas comuns, pois busca resultados unitários e uniformizadores sem esvaziar os poderes e competências dos entes federados em relação à União. A cooperação parte do pressuposto da estreita interdependência que existe em inúmeras matérias e programas de interesse comum. Todos os entes federados devem colaborar para a execução dessas tarefas.

Assim, Gilberto Bercovici aponta que a cooperação se firma em dois momentos, o primeiro se dá em nível federal, quando se determina as medidas a serem adotadas, uniformizando-se a atuação de todos os poderes estatais competentes em determinada matéria. O segundo momento ocorre em nível estadual ou municipal, quando cada ente federado adapta a decisão tomada em conjunto às suas características e necessidades ${ }^{115}$.

Sob essas considerações deverá o intérprete balizar as legislações dos diferentes entes federados utilizadas para o desempenho de suas competências comuns, como será delineado na segunda parte desse trabalho. Pois o grande objetivo do federalismo, na atualidade, é a busca da cooperação entre União e entes federados, equilibrando a descentralização federal com imperativos de integração econômica nacional, a ser realizado mediante o planejamento coordenado dos entes federados, para ditar política pública eficaz e integradora à toda Federação.

Nesse sentido é a conclusão de Christina Pedreira ao ponderar que o aspecto primordial do Estado federado do tipo cooperativo é o reconhecimento de que todos os entes integrantes da Federação são cotitulares de interesses comuns, cuja promoção se desenvolve por meio da atuação conjunta e indissociável, assegurando-se a todos eles o respeito recíproco; afinal, há interesses próprios e poderes diferenciados. A solução está na equação equilibrada destes dois últimos elementos ${ }^{116}$.

Realmente, fiel à diretriz do federalismo cooperativo, a autonomia políticoadministrativa dos entes federados não enfraquece ou compromete a atuação harmoniosa dos seus entes.

\footnotetext{
${ }^{114}$ ROVIRA apud BERCOVICI, 2004, p. 60.

${ }^{115}$ BERCOVICI, 2004, p. 61

${ }^{116}$ PEDREIRA, 2008, p. 34.
} 
Consigne-se, por fim, que a vindoura legislação complementar prevista no parágrafo único do art. 23 da CF poderá melhor divisar a cooperação dos entes federados, fiel aos apontamentos da doutrina - onde caberá à União apontar as diretrizes da política pública e aos demais entes federados a definição de suas peculiaridades e necessidades. Assim, eventuais conflitos legislativos poderão ser evitados, na esteira dos apontamentos supra apontados diretamente pelo intérprete. Oxalá que a futura positivação da legislação complementar possa também especificar os caminhos da cooperação entre os entes federados na execução da competência comum também para prevenir futuros conflitos legislativos e administrativos. 


\section{Capítulo III: Interpretação Constitucional e Soluções de Conflitos 3.1. A Neointerpretação Jurídica Constitucional}

Nessa segunda fase do trabalho pretende-se expor os caminhos que o intérprete trilhará na interpretação das competências legislativas, seu alcance e sua interação com os demais dispositivos que regram assuntos que se inter-relacionam, já que na maior parte das vezes, o legislador disciplina uma matéria com incursões em tantas outras. Traçar-se-á as abordagens que melhor amparam a divisão constitucional de competências de modo a resguardar a efetiva distribuição de poderes e prerrogativas dos entes federados, na busca de um resultado que otimize as diretrizes constitucionais apresentadas nos capítulos anteriores. Pois o Direito só ganha legitimidade a partir da sua realização prática.

Daí a razão de Martin Kriele afirmar que não se pode interpretar nenhum texto jurídico a não ser colocando-o em relação com problemas jurídicos concretos (reais ou imaginários), com as soluções aos casos ocorrentes, porque é somente na sua aplicação aos fatos da vida e na concretização, que necessariamente se processa, que se revela completamente o conteúdo significativo da norma ${ }^{117}$.

Para tanto, imperativo traçar algumas linhas sobre a interpretação e os métodos da neohermenêutica constitucional que tem a desafiante tarefa de melhor equacionar os conflitos jurídicos constitucionais e assim amparar o hermeneuta na busca do melhor caminho de suas decisões.

Consoante entende Lenio Streck, a palavra hermenêutica deriva do grego hermeneuein, cuja mitologia descreve como um mensageiro divino, que transmite - e portanto, esclarece - o conteúdo da mensagem dos deuses aos mortais. Trata-se, pois, de transmitir sentido à mensagem, um ato de (inter)mediação ${ }^{118}$. A Hermenêutica é tida como o campo da ciência que estuda a interpretação, o seu domínio teórico especulativo. Atualmente, apresenta capital importância ao debate doutrinário, constituindo hoje, tema central da metodologia do Direito,

\footnotetext{
${ }^{117}$ MENDES. Gilmar Ferreira; COELHO, Inocêncio; BRANCO, Paulo G. Curso de direito constitucional. São Paulo: Saraiva, 2007, p. 49.

118 STRECK, Lenio. Apresentação. In: TRIBE, Laurence; DORF, Michael. Hermenêutica Constitucional. Belo Horizonte: Del Rey, 2007, p. Xiii.
} 
quiçá em razão dos novos caminhos traçados pela doutrina que a fundamenta. ${ }^{119}$ Sob os impulsos do positivismo normativo, interpretar é a atividade prática de explicitar o resultado e alcance de um texto, para firmar sua incidência ao caso concreto; é a exegese da norma. Contudo, a evolução da dogmática jurídica tomou consciência de que a interpretação jurídica vai além da norma, congrega o contexto social, os fins dirigidos pela norma e os princípios que fundamentam o sistema para uma abordagem prático-normativa.

Nesse contexto que surge a hermenêutica constitucional, sufragada pelos avanços da Teoria da Linguagem, baseada na relevância do papel do intérprete e na separação do sujeito e objeto da interpretação, na efetividade dos princípios e no embasamento de doutrinas constitucionais heterogêneas ${ }^{120}$ como a de Ronald Dworkin, Robert Alexy, Peter Häberle, Gustavo Zagrebelsky, Luigi Ferrajoli, Carlos Santiago Nino e Hans Gadamer. É o que se verá.

Assim, o fenômeno da interpretação é inserto ao campo geral das ciências; no âmbito das ciências ditas de espírito - político-culturais - há uma inter-relação entre o intérprete (sujeito cognoscente) e o objeto (cognoscível) de interpretação, pois esse último tem valor de per si, de forma que a doutrina aponta que seu método de estudo é a compreensão, consistente na busca dialética da relação do signum à coisa significada. Ao contrário das ciências naturais que trabalham com a explicação, suscetível de um corte imediato, a compreensão requer uma interação contínua do intérprete sobre o objeto sob estudo, numa relação de completude.

Apropriada, pois, a metáfora utilizada por Rafael do Amaral ${ }^{121}$ ao fazer alusão à espiral para ilustrar o ato da compreensão como o avançar de uma antípoda à outra. Não se trata de repetir aquilo que já foi dito, mas de percorrer o caminho que já fora firmado e de se chegar naquilo que já foi pensado. Só assim, ter-se-á a interação necessária do caso concreto ao texto normativo para se alcançar a conclusão. Pois enriquecida a relação dialética do pensamento.

Tal assertiva é endossada pelos avanços da filosofia da interpretação propagada por Heidegger e Gadamer ${ }^{122}$ onde sustentam a importância da historicidade para compreensão do

\footnotetext{
${ }^{119}$ Essa constatação é também perfilhada no Direito Civil e na Filosofia do Direito - Cf. REALE, Miguel. Fontes e modelos do direito - para um novo paradigma hermenêutico. São Paulo: Saraiva, 1994, p. 112.

${ }^{120}$ É o posicionamento de SARMENTO, Daniel. O neoconstitucionalismo no Brasil: riscos e possibilidades. Revista Brasileira de Estudos Constitucionais. no 9, Belo Horizonte, jan/mar 2009, p. 95-133, 2009, p. 95-133.

${ }^{121}$ AMARAL, Rafael Caiado. Peter Häberle e a hermenêutica constitucional: alcance doutrinário. Porto Alegre: Sérgio Antonio Fabris, 2004, p. 39.

${ }^{122}$ Conforme interpretação de BLEICHER, Josef. Hermenêutica Contemporânea. Tradução: Maria G. Segurado. Lisboa: Edições 70, [s.d.].
} 
texto enunciado, pois esse advém do diálogo mantido entre o texto e seu intérprete. Gadamer entende, assim, que a dialética se concretiza na forma de pergunta e resposta, pois todo o conhecimento tem de passar pela pergunta.

Nessa linha, compreender o texto é perguntar o que ele está nos perguntando, interpretá-lo, mas sem fechar as hipóteses interpretativas. Mas para que ocorra essa interpretação é necessária uma reconstrução da pergunta que é transmitida, ou seja, superar o horizonte histórico que a própria tradição nos coloca.

Por sua vez, Emilio Betti, em sua obra Teoria Generalle dela Intepretazione, ensina que a interpretação jurídica é a forma de interpretação que vai além daquela utilizada histórica ou artisticamente, pois a interpretação jurídica requer um entender para agir ou decidir, e assim, posicionar-se diante de preceitos a observar como uma lei ou um tratado a aplicar ou de um contrato a executar.

Em outros termos, a interpretação jurídica mantém na vida de uma sociedade ou nas relações entre co-obrigados, preceitos, normas e juízos normativos, que são destinados a regular os vínculos intersubjetivos e a servir-lhes de orientação. Justamente em face desse entender para agir ou para decidir frente a preceitos a observar, existe aqui um círculo de reciprocidade e contínua relação entre a vigência da ordem jurídica, moral, etc, da qual se extrai a diretriz da ação, e o processo interpretativo também o faz, em sentido integrativo e complementar. Por conseguinte, interpretar não é apenas conhecer uma objetivação do pensamento completa em si mesma, mas tornar a conhecê-la, para integrá-la e realizá-la nas relações concretas $^{123}$.

Relevante, portanto, o papel do hermeneuta na dicção do contexto e na concretização da norma, em suma, na tarefa da interpretação-aplicação. A aplicação é justamente o momento final do processo interpretativo, a concretização do preceito sobre o fato; uma etapa considerada em si mesma, numa palavra: a concretização normativa.

Elival da Silva Ramos observa, com propriedade, que a Hermenêutica atual concebe a interpretação-aplicação como parte de uma estrutura lógica de compreensão complexa e dinâmica, comandada por uma relação dialética de polaridade-implicação entre o sujeito cognoscente e o texto normativo, relação dialética essa que também existe entre as duas

\footnotetext{
${ }^{123}$ BETTI, Emilio. Teoria generalle della interpretazione. Milano: Giuffrè, 1955. v. 2. p. 802-803.
} 
atividades que aquele simultaneamente exerce, a interpretação e a aplicação, mutuamente implicadas, embora lógica e conceitualmente distintas ${ }^{124}$.

Portanto, desse processo aflora a norma decisão, cujos referenciais advêm do próprio texto normativo, da consciência jurídica do aplicador e sua visão de mundo, dos elementos fáticos e do contexto social e político. Congrega-se, pois, critérios objetivos e subjetivos, ora impelidos da própria norma, ora da prudência e da sensibilidade do intérprete em sintonia com os princípios que humanizam o Direito e conferem funcionalidade ao sistema. É salutar que seja assim. Veja-se essa evolução.

A interpretação moderna, que se pode chamar de neointerpretação, apresenta linha divisora da interpretação clássica a partir do abandono do silogismo puro interpretativo que imperou no séc. XIX, cujo apogeu fora positivado no Código Civil de Napoleão de 1804, que via no interpretar um mero ato de conhecimento pronto e acabado - através da fria e implacável operação lógica de subsunção, de índole dedutiva, em que o aplicador oficial do direito se limitava à mecânica adequação dos fatos (premissa menor) à proposição normativa correspondente (premissa maior), e conseqüente sanção então tipificada na lei.

Deveras, por um período significativo a atividade inerente do aplicador do direito esteve enclausurada no vetusto brocardo interpretatio cessat in claris, que restringiu a grandeza humanística do Direito, pois, como é sabido, a aplicação fenomênica do Direito é infinitamente mais criativa que a mente do legislador que evidentemente não contempla todas as soluções reais para a vida, sobretudo na hermenêutica constitucional que utiliza valores fluidos e dilatórios para concretizar-se sobre as demais normas.

O determinismo histórico explica essa assertiva hermética de estrita subsunção que cunhou o intérprete pelo século XIX e boa parte do século XX, pois a Revolução Francesa aboliu o Ancien Régime e todo resquício de axiologia que então prevalecia, para só encontrar no direito positivo, através do Parlamento, o regramento do Direito. A lei passou a simbolizar não só a vontade geral da nação, mas a soberania popular e a única expressão do Direito, de sorte que expurgou do sistema toda conjuntura filosófica que não estava descrita no texto legal - situação que empobreceu o Direito e a própria Hermenêutica Jurídica.

\footnotetext{
${ }^{124}$ RAMOS, Elival Silva. Parâmetros dogmáticos do ativismo judicial em matéria constitucional. 2009. Tese apresentada à Faculdade de Direito da Universidade de São Paulo (Fadusp), visando ao provimento de cargo de Professor Titular ao Departamento de Direito de Estado. São Paulo, 2009, p. 56-57. Observa, contudo, algumas críticas ao ativismo judicial realizado além do sistema normativo firmado pelo enunciado do texto.
} 
No ápice da doutrina liberal o Poder Judiciário tinha atribuição restrita de apenas pronunciar a aplicação da lei aos casos concretos de modo mais neutro e inativo possível, eis que se temia atribuição de poder ao Judiciário, pois tido como órgão ligado à Monarquia; e, como tal, não se admitia qualquer discricionariedade política, situação que deu ensejo à pseudo-separação da política e do Direito. Daí as palavras de Montesquieu que cunhou a ideologia de que os juízes são apenas a boca que pronuncia as palavras da lei; seres inanimados que não lhe podem moderar nem força, nem o rigor ${ }^{125}$.

Eis a fraqueza que arrefeceu o Direito na sua concepção de efetiva aplicação ao caso concreto, a qual foi paulatinamente preenchida pela recomposição da interpretação e aplicação principiológica do Direito que rompeu a hermética subsunção do fato à norma. Exsurge, daí, o relevo da Teoria da Interpretação justamente para compor essas vicissitudes sistêmicas do positivismo jurídico e nesse contexto a chamada neo-hermenêutica. Esse fenômeno foi lento e gradual $^{126}$, precedido de mudanças na própria Teoria Geral do Direito do último século, que formataram os passos vindouros da chamada neo-hermenêutica constitucional, sobretudo na transposição do foco então vigente e da agregação de novos valores ao sistema jurídico.

Essa nova abordagem interpretativa constitucional foi intensamente influenciada pelas mudanças político-sociológicas que marcaram os novos caminhos filosóficos da Teoria Geral do Direito - essa última sintetizada de modo marcante na obra de Bobbio, Teoria do Ordenamento Jurídico.

Deveras, a maior guinada que ocorreu no campo da Ciência Jurídica no último século foi o efetivo avanço, ou, talvez, a retomada da influência sociológica e política no mundo das normas, situação também vivenciada na construção da chamada nova hermenêutica constitucional. Contudo, essa é mero reflexo daquela, pois a primeira constatação é a causa, e, a última, o efeito. E, como tal, o fenômeno da segunda não é de todo original.

Essa constatação é visível na obra de Norberto Bobbio, nas palavras de Tercio Sampaio Ferraz, ${ }^{127}$ quando faz a apresentação sobre a obra do jurista italiano ao comentar que

\footnotetext{
${ }^{125}$ MONTESQUIEU, Charles-Louis de Secondat, Baron de. O espírito das leis: as formas de governo, federação, a divisão dos poderes, presidencialismo versus parlamentarismo. 6. ed. Tradução de Pedro Vieira Mota. São Paulo, Saraiva, 1999, p. 170-178.

${ }^{126}$ Note-se, ainda, a existência de doutrinas jurídicas que focavam o estudo e a importância da interpretação, como a Escola da Exegese.

${ }^{127}$ BOBBIO, Norberto. Teoria do ordenamento jurídico. 10. ed. Tradução de Maria Celeste Santos. Brasília: Editora da UnB, 1999.
} 
Bobbio soube como ninguém enfrentar a crise do direito no último século justamente em razão da mudança de paradigmas:

\begin{abstract}
No âmbito da Ciência Jurídica, mais do que muitos, Norberto Bobbio soube entender que se, nos primeiros três quartos deste século, a grande preocupação foi eliminar juízos de valor no intento de construir uma teoria científica do Direito não sujeita a implicações ideológicas, agora, em compensação, recupera-se em sua esfera de interesses a experiência social e o juízo crítico sobre si mesma, oferecendo à investigação jurídica novas dimensões.

Quando a sociedade atravessa uma fase de profundas mudanças, admitiu Norberto Bobbio mais recentemente, a Ciência do Direito precisa estabelecer novos e chegados contatos com as Ciências Sociais, superando-se a formação jurídica departamentalizada, com sua organização, sobre uma base corporativo-disciplinar, de compartimentos estanques.

Pois bem: essa sensibilidade para a mudança, sem perder de vista as exigências da racionalidade, é uma das mais importantes características de Norberto Bobbio e a lição mais profunda que podemos extrair de seu pensamento.
\end{abstract}

Em outros termos, o Direito então visto como pura construção normativa, cuja construção simplista de aplicação era meramente dedutiva, ruiu ao fim do século passado, para então incorporar na sua interpretação e no seu fio condutor elementos humanísticos e válvulas de escape que condicionam, filtram e racionalizam o mundo das normas, os princípios, valores e paradigmas novos voltados a otimizar a sua aplicação.

Essa assertiva advém do próprio estudo da Ciência Jurídica, em especial porque o positivismo jurídico não atribuiu a necessária importância à Teoria da Interpretação, não tanto por constituir a subsunção mecânica dos fatos concretos às prescrições legais um dogma positivista, mas também pela parca dedicação do positivismo ao binômio interpretaçãoaplicação e seus desdobramentos no plano da teoria da argumentação, consoante assinala Elival da Silva Ramos. Observa, assim, o constitucionalista que o "calcanhar de Aquiles" do positivismo jurídico é justamente a fraqueza de sua abordagem à Teoria da Interpretação ${ }^{128}$, quiçá em razão do positivismo encarar obstinadamente o direito como uma ciência materializada na obra de Hans Kelsen, A Teoria Pura do Direito, na qual procura descrever tão somente o seu objeto, e relegar a aplicação do seu objeto, em especial o binômio interpretação-aplicação.

Essa guinada do Direito foi acompanhada de perto pelo progresso da teoria da comunicação ou da linguagem no âmbito da Filosofia, em especial pela contribuição de

\footnotetext{
${ }^{128}$ RAMOS, 2009.
} 
Heidegger e Gadamer ${ }^{129}$. Para esse último, citado por Bleicher, o problema da linguagem constitui o tema central da filosofia hermenêutica, o que representa uma gigantesca reorientação da hermenêutica, libertando-a dos condicionalismos que ela impunha a si própria no seu esforço aturado de garantir a objetividade metódica. Propõe uma reflexão hermenêutica sobre a história efectual, subjacente a todo pensamento ${ }^{130}$.

A evolução do constitucionalismo endossa essa orientação, pois até a Segunda Guerra Mundial prevalecia no velho continente uma cultura jurídica essencialmente legicêntrica, que tratava a lei editada pelo parlamento como a fonte principal - quase como fonte exclusiva - do Direito, e não atribuía força normativa às constituições, conforme leciona Zagrebelski ${ }^{131}$. Pois as constituições eram vistas basicamente como normas programáticas para inspirar o legislador, mas que não conferiam direito subjetivo.

Em que pese o enfraquecimento do positivismo jurídico estrito, a doutrina destaca que não parece possível pensar uma teoria do direito que não seja em alguma medida positivista ${ }^{132}$. Contudo, sua imposição normativa não é tão simples como outrora se imaginava. Muitas vezes o intérprete terá diante de si desafios interpretativos, de modo a ponderar direitos e prerrogativas em face de um princípio regente do sistema, baseado nas circunstâncias materiais e valorativas que guarnecem a causa, cuja análise deverá ser minuciosa e prudentemente analisada pelo aplicador do direito.

\footnotetext{
${ }^{129}$ BLEICHER, [s.d.].

${ }^{130}$ BLEICHER, [s.d.], p. 178. No texto original Gadamer observa que pela dialética da pergunta e da resposta descobrimos que a estrutura da experiência hermenêutica nos permitirá determinar mais detidamente o que caracteriza esse tipo de consciência chamada consciência da história efeitual. Isso porque a dialética de pergunta e resposta que expusemos acima apresenta a relação da compreensão como uma relação recíproca semelhante à relação que se dá na conversação. É verdade que um texto não nos fala como o faria tu. Somos só nós, que compreendemos, que temos de trazê-lo à fala a partir de nós mesmos. Mas já vimos que esse trazer à fala, próprio da compreensão, não é uma intervenção arbitrária de uma iniciativa pessoal, mas refere, por sua vez, como pergunta à resposta latente do texto. A latência de uma resposta pressupõe, por sua vez, que aquele que pergunta foi atingido e se sente interpelado pela própria tradição. Esta é a verdade da consciência da história efeitual. Na medida em que nega o fantasma de um esclarecimento total, e justo por isso, a consciência dotada de experiência histórica está aberta para a experiência da história. Descrevemos sua maneira de realizar-se como a fusão de horizontes do compreender que faz a intermediação entre o texto e seu intérprete. GADAMER, Hans-Georg. Verdade e método. Tradução: Flávio Meurer, $7^{\text {a }}$ ed. Petrópolis: Vozes, Bragança Paulista: EDUSF, 2005, p. 486.

${ }^{131}$ ZAGREBELSKI apud SARMENTO, 2009, p. 98

${ }^{132}$ FIGUEIROA, Alfonso Garcia. A teoria do direito em tempos de constitucionalismo. Revista Brasileira de Estudos Constitucionais - RBEC. Belo Horizonte, n. 4, p. 77-102, out./dez. 2007, p. 102.
} 
Erige-se, nessa dinâmica a chamada neo-hermenêutica ${ }^{133}$ constitucional que fora construída a partir de novos impulsos filosóficos no âmago da interpretação-aplicação do Direito. Parte-se de uma estrutura lógica de compreensão baseada na relação dialética entre o sujeito cognoscente (intéprete-aplicador) e aquilo que procura compreender de um objeto cognoscível (o texto normativo).

Somente com o equilíbrio dessa relação ter-se-á uma base científica imparcial para a interpretação. Tanto porque um dos pilares da neo-hermenêutica é a distinção entre o texto normativo (o dispositivo ou enunciado) e o seu conteúdo (a norma jurídica que se aflora), sendo aquele objeto da interpretação e esse o resultado - fruto dessa relação dialética que mede, analisa e interage com as demais circunstâncias fáticas e valorativas, ingredientes naturais da norma decisão.

A nova conjuntura da Hermenêutica Constitucional prega a idéia de que o Direito não se exaure na lei, de forma que o intérprete tem papel fundamental como operador do Direito e da Justiça. Prega a integração do Direito às demais ciências sociais e culturais - idéia da necessária interdisciplinariedade. Ataca a idéia abstrata da completude formal do positivismo e de sua estrita concepção formalista ao enriquecer o papel do intérprete na aplicação do Direito, visto como um plus ignorado pelo positivismo clássico.

A peculiaridade da chamada neo-hermenêutica é a reaproximação axiológica aos valores, e, sobretudo, o reconhecimento da normatividade dos princípios - já reconhecidos anteriormente, mas com sua aplicação e importância demasiadamente relegados. Esses passaram a ser a síntese dos valores abrigados no ordenamento jurídico, espelham a ideologia da sociedade, seus postulados e fins. Têm como papel fundamental: a) condensar valores; b) dar unidade ao sistema; c) condicionar a atividade do intérprete. ${ }^{134}$

A neo-hermenêutica não abandona a teoria geral da subsunção convencional (relevante, mas não suficiente), contudo agrega as seguintes características: 1) normatividade dos princípios; 2) efetividade das normas constitucionais, até mesmo quanto às normas axiológicas, em razão da força normativa da Constituição; 3) filtragem constitucional -

\footnotetext{
${ }^{133}$ Há sérias críticas quanto ao termo neo-hermenêutica, pois os mesmos métodos aqui defendidos já foram utilizados anteriormente como Giorgio del Vechio e Miguel Reale, entre outros que postulavam a inserção da ética e dos valores no âmbito jurídico - nesse sentido é o pensamento de FERREIRA FILHO, 2009, p. 151-167.

${ }^{134}$ BARROSO, Luis Roberto (Org.). A nova interpretação constitucional: ponderação, direitos fundamentais e relações privadas. Rio de Janeiro: Renovar, 2003, p. 29-30.
} 
fenômeno que acarreta repercussão aos outros ramos do Direito dos princípios constitucionais, de forma a interpretar seus institutos à luz da Constituição; 4) uso da tópica para interpretar os hard cases, até mesmo com a utilização de raciocínio indutivo.

Conseqüências da neo-hermenêutica:

i) Queda da crença de que as normas jurídicas em geral - e as normas constitucionais em particular - tragam sempre em si um sentido único, objetivo, válido para todas as situações sobre as quais incidem, um sentido unívoco. À vista dos elementos do caso concreto, dos princípios a serem realizados é que será determinado o sentido da norma, com vistas à produção da solução constitucionalmente adequada para o problema a ser resolvido ${ }^{135}$. Tanto porque o Direito Constitucional trabalha com conceitos abertos, cláusulas dilatórias e principiológicas que dependem da realidade subjacente, de sorte que não apresentam sentido unívoco e inexorável para todas as situações da vasta realidade fática e valorativa.

Surge no âmago do Direito Constitucional uma interpretação evolutiva, de forma que a sistematização, a hierarquia de fins não é historicamente fixa, mas depende da assunção de meta-valores por parte da interpretação adequada aos fatos emergentes ${ }^{136}$. Supera-se, portanto, a visão hermética do originalismo no âmbito do Direito Constitucional, pois o Direito evolui com a sociedade.

Enfim, as normas constitucionais firmam uma moldura dentro da qual se encontram distintas aplicações, e todas são interpretações jurídicas conforme ao Direito se insertas nesse quadro. E somente à luz das circunstâncias do caso concreto e da interação dos valores, ter-seá que determinar o sentido da norma que atende os valores constitucionais preponderantes para o problema a ser solucionado.

Essa constatação já fora antevista até mesmo pelo próprio Hans $\operatorname{Kelsen}^{137}$ ao arrematar que:

Em todos estes casos de indeterminação, intencional ou não, do escalão inferior, oferecem-se várias possibilidades à aplicação jurídica. $\mathrm{O}$ ato jurídico que efetiva ou executa a norma pode ser conformado de maneira a corresponder a uma ou outra das várias significações verbais da mesma norma, de maneira a corresponder à vontade do legislador (...). O Direito a aplicar forma, em todos estas hipóteses, uma moldura

\footnotetext{
${ }^{135}$ BARROSO, 2003, p. 331-332.

${ }^{136}$ ZAGREBELSKY, Gustavno. Diritto Costituzionale: Il Sistemma delle Fonti del Diritto. 1. ed. [1988]. Torino: Unione Tipográfico-Editrice Torinese, 1998. v.1, p. 83.

137 KELSEN, Hans. Teoria pura do direito. 2. ed. Tradução de João Baptista Machado. São Paulo: Martins Fontes, 1991, p. 366-371.
} 
dentro da qual existem várias possibilidades de aplicação, pelo que é conforme ao Direito todo ato que se mantenha dentro deste quadro ou moldura, que preencha esta moldura em qualquer sentido possível.

Se por "interpretação" se entende a fixação por via cognoscitiva do sentido do objeto a interpretar, o resultado de uma interpretação jurídica somente pode ser a fixação da moldura que representa o Direito a interpretar e, conseqüentemente, o conhecimento das várias possibilidades que dentro dessa moldura existem. Sendo assim, a interpretação de uma lei não deve necessariamente conduzir a uma única solução como sendo a única correta, mas possivelmente a várias soluções que - na medida em que apenas sejam aferidas pela lei aplicar - têm igual valor, se bem que apenas uma delas se torne Direito positivo no ato do aplicador do Direito - no ato do Tribunal especialmente. Dizer que uma sentença judicial é fundada na lei, não significa, na verdade, senão que ela está contida na moldura ou quadro que a lei representa - não significa que ela é a norma individual, mas apenas que é uma das normas individuais que podem ser produzidas dentro da moldura da norma geral.

(...)

Com efeito, a necessidade de uma interpretação resulta justamente do fato de a norma aplicar ou o sistema das normas deixarem várias possibilidades em aberto, ou seja, não conterem ainda qualquer decisão sobre a questão de saber qual dos interesses em jogo é o de maior valor; mas deixarem antes esta decisão, a determinação da posição relativa dos interesses, a um ato de produção normativa que ainda vai ser posto - à sentença judicial, por exemplo.

$[\ldots]$

A interpretação jurídico-científica tem de evitar, como máximo cuidado, a ficção de que uma norma jurídica apenas permite, sempre e em todos os casos, uma só interpretação "correta". Isto é uma ficção de quer se serve a jurisprudência tradicional para consolidar o ideal da segurança jurídica. Em vista da plurissignificação da maioria das normas, este ideal somente é realizável aproximadamente.

Contudo, Kelsen firmava estrita separação do Direito e da Política, ao considerar que a efetiva escolha da norma-decisão não se faz por critérios jurídicos, mas políticos ou éticos ${ }^{138}$. O jurista de Viena traçava, assim, rígida separação entre o Direito e a política, de tal forma que não os entrelaça. Entretanto, ponderamos que essa constatação não é de tamanha rigidez, pois em razão da atual normatividade dos princípios que congregam valores ético-normativos ao sistema, é viável construir um raciocínio em sintonia com a diretriz jurídica que emana da análise fática e técnica do caso em apreço. É o que destacaremos no item a seguir.

ii) A relevância da ponderação na análise de casos em conflitos.

\footnotetext{
${ }^{138}$ Em suas palavras: "A questão de saber qual é, entre as possibilidades que se apresentam nos quadros do Direito a aplicar, a "correta”, não é sequer - segundo o próprio pressuposto de que se parte - uma questão de conhecimento dirigido ao Direito positivo, não é um problema de teoria do Direito, mas um problema de política do Direito. A tarefa que consiste em obter, a partir da lei, a única sentença justa (certa) ou o único ato administrativo correto é, no essencial, idêntica à tarefa de quem se propõe, nos quadros da Constituição, criar as únicas leis corretas, tampouco podemos, a partir da lei, por interpretação, obter as únicas sentenças corretas." (KELSEN, 1991, p. 368).
} 
Por força da efetiva normatividade dos princípios no sistema jurídico releva a distinção entre regras e princípios. Ou seja, a resposta da norma da decisão advém não só das regras, mas também dos princípios que arejam as engrenagens da sistemática jurídica e modulam maior sensatez aos valores fundantes do ordenamento jurídico. Recorrendo à metáfora, os princípios representam os amortecedores do veículo que assentam cômodo posicionamento ao motorista nos solavancos da estrada para manter firme a condução do Direito perante a árida estrada de embates de toda ordem, próprio do mundo fenomênico.

Vivencia-se, pois, o reconhecimento da efetividade dos princípios $^{139}$ como fundamentos constitutivos e normativos do Direito, o que conduz à possibilidade de uma interpretação conforme os princípios. Recorrer a um princípio significa formular uma regra com base na qual se resolve o caso em tela, modificando-se a ingênua convicção de que as regras já se encontram formadas antes da sua aplicação e que, portanto, a tarefa do Juiz limitase a aplicar a regra apropriada ao caso. Enfim, cuida-se da passagem metodológica da ratio legis à ratio iuris, isto é, do sentido da norma legal ao sentido dos fundamentos do próprio sistema, consoante enfatiza o português Castanheira Neves ${ }^{140}$.

Contudo, há de se esclarecer que as regras ainda representam a célula padrão do sistema jurídico e fundam a composição ordinária da estrutura jurídica, baseada num conjunto hierarquizado de regras que se inter-relacionam - ideologia própria do positivismo clássico cuja aplicação obedece ao chamado tudo ou nada, conforme preconizado por Dworkin ${ }^{141}$.

\footnotetext{
${ }^{139}$ Não se nega a existência de princípios há séculos atrás. Contudo, sua força normativa, salvo raras exceções, não alcança resultados ou direitos subjetivos para aquele que o postulava.

${ }^{140}$ NEVES apud AMARAL, Francisco. A interpretação jurídica segundo o Código Civil. Revista do Advogado, São Paulo, n. 98, p. 90-100, jul. 2008, p. 98.

${ }^{141}$ DWORKIN, Ronald. Taking rights seriously. Cambridge: Harvard University Press, 1977, p. 24-26. "The difference between legal principles and legal rules is a logical distinction. Both sets of standards point to particular circumstances, but they differ in character of the direction they give. Rules are apllicable in an all-ornothing fashion. If the facts a rule stipulates are given, then either the rule is valid, in wich case the answer it supplies must be accepted, or it is not, in wich case it contributes nothing to the decision. (...) But this is not the way the sample principles in the quotations operate. Even those wich look most like rules do not set out legal consequences that follow automoatically when the conditions provided are met. (...) This first difference between rules and principles entails another. Principles have a dimension that rules do not - the dimension of weight or importance. When principles intersect (...), one who must resolve the conflict has to take into account the relative weight of each." Em vernáculo: "A diferença legal entre princípios e regras é de ordem lógica. Ambas partem de um ponto padrão para circunstâncias particulares, mas diferem no caráter de sua aplicação. Regras são aplicáveis do modo tudo ou nada. Se os fatos normativos surgirem a regra é aplicável, caso em que o comando normativo da regra é aceito, ou não o é, caso em que nada contribui para a decisão. (...) Mas não é esse o modo como os princípios agem. Apesar de aparentarem semelhanças às normas, os princípios não seguem uma sequência automática de incidência tal como a regra, quando presentes os fatos normativos. (...) Essa primeira diferença de aplicabilidade entre princípios e regras aponta para uma outra. Princípios têm uma dimensão que
} 
Em suma, as regras apresentam estrutura simples de aplicabilidade, aplicam-se a dado fenômeno fático ou não, a teor do substrato fático que descrevem, $e$. $g$. "Se é A, deve ser B”. Como visto, as regras não admitem meio termo, ao contrário dos princípios que admitem ponderações. Eis a razão da denominação utilizada por Robert Alexy ${ }^{142}$ de cunhar as regras como comandos de definição e os princípios de comandos de otimização, como explicitaremos a seguir.

De outro giro, as regras descrevem comportamentos, sem se ocupar diretamente com os fins das condutas descritas, ao passo que os princípios invertem essa sistemática; apontam os objetivos, sem explicitar necessariamente as ações que devem ser firmadas para alcançálos. As regras são normas que estabelecem desde logo os efeitos que pretendem produzir no mundo dos fatos, efeitos determinados e específicos (condutas) ao passo que os princípios indicam efeitos relativamente indeterminados ${ }^{143}$ - justamente por se cuidar de conceitos fluidos que amoldam as regras aos fins do sistema, sob a perspicácia e prudência do aplicador do Direito.

Assim, os princípios são normas jurídicas que apresentam estrutura de aplicabilidade distinta, pois não são biunívocos como as regras. Operam ativamente no ordenamento ao condicionarem a leitura das regras, suas contextualizações e inter-relações, ao possibilitarem a integração construtiva da decisão adequada de um hard case $^{144}$. Em outros termos, pode-se dizer que os princípios admitem gradações, tanto porque sua adimplência é realizada na medida do possível, de acordo com as circunstâncias fáticas e jurídicas. Daí a inteligência da nomenclatura de Alexy, ao nominar os princípios de comandos de otimização ${ }^{145}$.

Dessa distinção releva assinalar que ao contrário dos princípios, as regras por força de sua estrutura não são ordinariamente hábeis de ponderação, pois os seus efeitos são factíveis ou não. Assim, quando a regra apresenta situação fática especial em relação ao

\footnotetext{
as regras não têm - a dimensão do peso ou de sua importância. Quando princípios se entrecruzam (...) aquele que tem que resolver o conflito leva em consideração o peso de cada qual.” - tradução livre.

142 ALEXY, Robert. Teoría de los derechos fundamentales. Tradução por Ernesto Garzón Vládes. Madrid: Centro de Estudos Constitucionales, 1993, p. 86.

143 BARCELlOS, Ana Paula de. Alguns parâmetros normativos para a ponderação constitucional. A nova interpretação constitucional: ponderação, direitos fundamentais e relações privadas. Rio de Janeiro: Renovar, 2003, p. 49-118.

${ }^{144}$ CARVALHO NETO, Menelick de. A hermenêutica constitucional sob o paradigma do Estado Democrático de Direito. Notícia do Direito Brasileiro, Brasília, n. 6, p. 233-250, 1998, p. 245.

${ }^{145}$ ALEXY, 1993.
} 
princípio, aquela deve imperar. Ou seja, ordinariamente as regras têm preferência sobre os princípios, tanto porque os princípios constitucionais são por excelência moldados pelo legislador ordinário, através das regras que compactuam espaço razoável para sua adimplência.

Em outros termos, a observância de um princípio constitucional deve ser realizada à luz das circunstâncias do caso concreto e em sintonia com a legislação ordinária para, assim, apurar suas condições de aplicabilidade. Logo, o legislador ordinário amolda a aplicabilidade do princípio através das regras, desde que respeite o núcleo essencial do valor desse princípio - cuja avaliação é casuística e sujeita ao senso de adequabilidade ao Estado Democrático de Direito, aferível pela persuasão racional do jurista.

De outro modo, pode-se dizer que o princípio poderá ser restringido, ou melhor, o comando de otimização de um valor pode ser arrefecido quando: (a) uma regra apresenta situação que o excepcione razoavelmente ${ }^{146}$; (b) mediante ponderação com outro princípio que assenta valor constitucional de igual magnitude.

Realmente, em caso de conflitos entre princípios, a solução é a ponderação de valores ou de interesses, técnica que procura estabelecer o peso relativo de cada um dos princípios contrapostos ao caso fático, para assim se aferir com mais propriedade e senso crítico a solução ao caso apresentado - rompe-se, assim, o sistema hermético que prendia o intérprete, o aplicador do Direito. Recupera-se assim, o juízo crítico do sistema e sua função social; enfim, aclara-se com mais luz o próprio Direito.

Marcante, pois, anotar a importância que a ponderação tem na composição dos conflitos, seja entre princípios ou valores e até mesmo na interpretação de regras abertas (como os conceitos fluidos do legislador firmado em regras ${ }^{147}$ ). Seu propósito é solucionar conflitos normativos de modo mais sensato à realidade e aos valores em apreço, de forma que não se despreze qualquer das regras em confronto, mas se adote postura que privilegie o valor de maior magnitude constitucional à luz das circunstâncias do caso - de forma que privilegia a técnica argumentativa e crítica própria do Direito, como fenômeno sócio-político e normativo.

\footnotetext{
${ }^{146}$ Essa medida de razoabilidade é imprescindível para a regra imperar no caso concreto, pois invertida a razoabilidade na regra, essa será inconstitucional se advier da legislação ordinária e afrontar princípio de magnitude constitucional, como quando firma restrição além do razoável (princípio da menor restrição possível); ou quando a regra vulnerar o núcleo essencial do princípio.

147 Entre tantos, podemos destacar o conceito de função social do contrato ou da propriedade ou o conceito de mulher honesta, então utilizado pelo legislador penal antes da Reforma
} 
Humberto Ávila ratifica essa orientação ao aprofundar o papel da ponderação para além dos princípios propriamente ditos no âmbito do conflito normativo. Ensina o estudioso que a ponderação não é método privativo de aplicação dos princípios, enquanto sopesamento de razões e contra-razões que culminam com a decisão de interpretação, de forma que também é aplicável entre dispositivos de regras hipoteticamente contraditórios. Defende que a solução ao conflito situa-se no plano da aplicação, e não da validade, de forma que a ponderação concreta do caso apontará a solução mais sensata ao caso, diante das finalidades que estão em jogo ${ }^{148}$.

Advoga, ainda, que muitas vezes a exceção pode estar prevista no próprio ordenamento jurídico, hipótese em que o aplicador deverá, mediante ponderação de razões, decidir se há mais razões para a aplicação da hipótese normativa da regra ou, ao contrário, para a de sua exceção. Nesse sentido, decidiu a Suprema Corte brasileira quanto à aplicação de exceção contida na própria lógica do ordenamento quanto à presunção de violência de estupro (art. 213, CP), ao decidir que essa presunção é relativa, a teor do caso concreto e das circunstâncias particulares do caso em apreço ${ }^{149}$.

No esteio desse raciocínio Ana Barcellos observa que em ocasiões de crise (situações de ruptura) quando a aplicação de regras abstratamente válidas podem mostrar-se, em determinadas incidências, incompatíveis com outras disposições constitucionais ou profundamente injustas, admite-se a ponderação dos interesses que ela tutela através da aproximação do parâmetro da equidade. Ou seja: respeitado o limite do texto e suas possibilidade, o intérprete poderá empregar uma interpretação conforme a equidade da regra,

\footnotetext{
${ }^{148}$ ÁVILA, Humberto. Teoria dos Princípios: da definição à aplicação dos princípios jurídicos. $8^{\mathrm{a}}$ ed. São Paulo: Malheiros, 2008, p. 52-54. Exemplifica o raciocínio com o choque de normas abstratas do Código de Ética Médica que determina que o médico deve dizer para seu paciente toda a verdade sobre sua doença, e outra estabelece que o médico deve utilizar todos os meios disponíveis para curar seu paciente. Como deliberar o que fazer no caso em que dizer a verdade ao paciente sobre sua doença irá diminuir as chances da cura, em razão do abalo emocional daí decorrente ? Casos hipotéticos como esse não só demonstram que o conflito entre regras não é necessariamente estabelecido em nível abstrato, mas pode surgir no plano concreto, como ocorre normalmente com os princípios. Esses casos também indicam que a decisão envolve uma atividade de sopesamento entre razões.

${ }^{149}$ STF, $2^{\mathrm{a}}$ Turma, Rel. Min. Marco Aurélio, HC 73.662-Minas Gerais, DJ 20.09.96. Considerou o Min. Rezek expressamente em seu voto ao acompanhar o Ministro Relator, concedendo a ordem de habeas corpus, a convicção de que não concedê-la, significa proferir, no Supremo Tribunal Federal, uma tese jurídica de extremo risco: a de que a máquina judiciária está dispensada de raciocinar. Segundo se infere do julgado, exsurgindo dos autos prova de aparência física e mental de pessoa com idade superior aos 14 anos, impõe-se a conclusão sobre a ausência da configuração do tipo penal.
} 
de modo a evitar a incidência iníqua ${ }^{150}$ (tal como o STF entendeu a interpretação do estupro com presunção relativa, supra relatado).

Assim, quer em razão da sua relevância ao sistema, quer em razão da sua força pragmática para solver os conflitos, a ponderação tem-se destacado como elemento chave, de forma que merece estudo quanto à necessidade de se estabelecer parâmetros de controle, tanto normativos, como argumentativo.

A ponderação é, pois, um raciocínio jurídico lato, como se denota das palavras de Dworkin $^{151}$ :

\begin{abstract}
Os princípios, ao contrário das regras, podem ser contrários sem ser contraditórios, sem se eliminarem reciprocamente. E, assim, subsistem no ordenamento princípios contrários que estão sempre em concorrência entre si para reger uma determinada situação. A sensibilidade do juiz para as especificidades do caso concreto que tem diante de si é fundamental, portanto, para que possa encontrar a norma adequada a produzir justiça naquela situação específica. É precisamente a diferença entre os discursos legislativos de justificação - regidos pelas exigências de universalidade e abstração - e os discursos judiciais e executivos de aplicação - regidos pelas exigências de respeito às especificidades e à concretude de cada caso, ao densificarem as normas gerais e abstratas na produção das normas individuais e concretas - que fornece o substrato do que Klaus Günther denomina senso de adequabilidade, que no Estado Democrático de Direito é de se exigir do concretizador do ordenamento ao tomar decisões.
\end{abstract}

Daí a conclusão de Menelick de Carvalho Neto de que vivemos um novo paradigma na tomada de decisões, outrora idealista baseada na aplicação simplista das regras; agora se exige uma leitura procedimentalista de efetividade da Constituição e seus princípios, através da análise de senso de adequabilidade das regras frente aos princípios, ao contexto e às particularidades do caso, para que assim as decisões judiciais apresentem um nível de racionalidade discursiva, próprio do Estado Democrático de Direito, onde a cidadania e a participação popular na criação e aplicação do Direito é inerente ao sistema político e jurídico do País ${ }^{152}$.

iii) Regra que ordinariamente seja interpretada como constitucional, por força de elemento do próprio contexto e originalidade dos fatos concretos quando vulnerado o núcleo

\footnotetext{
150 BARCELLOS, 2003, p. 102-103. Serpa Lopes (1988, p. 145) observa: Em resumo podem ser fixados os seguintes princípios: a equidade, como função interpretativa da norma, independe de autorização legal, pois deve ser utilizada para coadjuvar a inteligência do dispositivo interpretando, de acordo com os dados sociológicos que o envolverem e a finalidade que tiver.

${ }^{151}$ DWORKIN apud CARVALHO NETO, 1998, p. 245-246.

${ }^{152}$ Também nesse sentido, Cf. HÄBERLE, Peter. Hermenêutica constitucional: a sociedade aberta dos intérpretes da Constituição. Porto Alegre: Fabris, 2004, p. 13.
} 
essencial do princípio - isto é, quando constatada a perda total do valor constitucional protegido pelo princípio sem se acautelar o mínimo vital desse interesse juridicamente protegido - ter-se-á conflito entre o valor constitucional positivado no princípio, o que enseja um efeito de inconstitucionalidade a ser conferido pelo intérprete. Constatada essa hipótese, deve-se paralisar a eficácia da regra, em nome do valor ou princípio constitucional vulnerado até porque é imperativa a consideração no processo interpretativo do seu impacto na realidade, para se saber se o produto da incidência da norma realiza finalisticamente o mandamento constitucional (i.g. não razoabilidade de atos normativos, etc.).

O próprio Supremo Tribunal Federal já abonou esse entendimento significativas vezes, de sorte que vale ressaltar a discussão realizada no bojo da $A_{D i n} n^{\circ} 223$, na qual se discutia a validade das disposições que proibiam a concessão de medidas liminares e antecipações de tutela em face da Fazenda Pública. A ação direta foi julgada improcedente (controle concentrado de constitucionalidade), eis que, em tese, a restrição à concessão de providências de urgência não era inconstitucional. Admitiu-se, porém, que em circunstâncias específicas a incidência daqueles dispositivos poderia gerar normas inconstitucionais, a ser deliberada em sede de controle difuso de constitucionalidade.

Da mesma forma decidiu o STF quanto ao afastamento de regra (Lei $\mathrm{n}^{\circ} 11.343 / 06$ ) que vedava o juiz instituir pena alternativa de liberdade aos condenados em tráfico de entorpecentes, diante do ultraje ao princípio constitucional da individuação da pena ao caso concreto. Impediu, pois, o Tribunal que se retire do juiz a individualização da pena em concreto, dessa vez em sede de controle difuso (HC 97256).

Com efeito, o primado dos princípios jurídicos faz crescer a importância do intérprete na tarefa de firmar os caminhos da aplicação do Direito através da efetiva análise e ponderação dos princípios para a fiel aplicação da Constituição e da legitimidade do próprio sistema jurídico.

É essa a interpretação que se deve buscar quando o aplicador do direito se depara com antinomia de um princípio constitucional versus regra infralegal, consoante explicita o constitucionalista Luís Roberto Barroso ${ }^{153}$, ao elucidar os atuais parâmetros de interpretação constitucional:

\footnotetext{
${ }^{153}$ BARROSO, 2003, p. 35-41.
} 
O novo século se inicia fundado na percepção de que o Direito é um sistema aberto de valores. A Constituição, por sua vez, é um conjunto de princípios e regras destinados a realizá-los, a despeito de se reconhecer nos valores uma dimensão suprapositiva. A ideia de abertura se comunica com a Constituição e traduz a sua permeabilidade a elementos externos e a renúncia à pretensão de disciplinar, por meio de regras específicas, o infinito conjunto de possibilidades apresentadas pelo mundo real. Por ser o principal canal de comunicação entre o sistema de valores e o sistema jurídico, os princípios não comportam enumeração taxativa. Mas, naturalmente, existe um amplo espaço de consenso, onde tem lugar alguns dos protagonistas da discussão política, filosófica e jurídica do século que se encerrou: Estado de direito democrático, liberdade, igualdade e justiça.

\section{$[\ldots]$}

O Princípio da Razoabilidade é um mecanismo para controlar a discricionariedade legislativa e administrativa. Ele permite ao Judiciário invalidar atos legislativos ou administrativos quando: a) não haja adequação entre o fim perseguido e o meio empregado; b) a medida não seja exigível ou necessária, havendo caminho alternativo para chegar ao mesmo resultado com menor ônus a um direito individual; c) não haja proporcionalidade em sentido estrito, ou seja, o que se perde com a medida tem maior relevo do que aquilo que se ganha. $O$ princípio, com certeza, não liberta o juiz dos limites e possibilidades oferecidos pelo ordenamento. Não é de voluntarismo que se trata. A razoabilidade, contudo, abre ao Judiciário uma estratégia de ação construtiva para produzir o melhor resultado, ainda quando não seja o único possível ou mesmo aquele que, de maneira mais óbvia, resultaria da aplicação acrítica da lei. A jurisprudência do Supremo Tribunal Federal tem se valido do princípio para invalidar discriminações infundadas, exigências absurdas e mesmo vantagens indevidas.

\section{$[\ldots]$}

As potencialidades da interpretação constitucional sob o influxo das idéias aqui expostas fazem surgir novas indagações. Uma delas consiste, precisamente, na possibilidade de conflito entre uma específica incidência da norma e um valor constitucionalmente protegido, abrigado em um princípio. Hipóteses podem ocorrer em que uma regra cujo relato em tese seja perfeitamente compatível com a Constituição, produza em relação a uma dada situação concreta um efeito inconstitucional. Neste caso, deve-se paralisar a eficácia da regra, em nome do valor ou princípio constitucional vulnerado.

Essa constatação não se circunscreve unicamente ao Direito Constitucional. Ao contrário, espraia-se pela Teoria Geral do Direito e tem forte viés também no Direito Civil ${ }^{154}$, embora seja mais fecunda no Direito Constitucional que não raras vezes trabalha com conceitos abertos, cláusulas dilatórias e princípios que embutem metodologia ao arcabouço de regras e fundam valores em sua perspectiva axiológica.

\footnotetext{
${ }^{154}$ Nesse sentido preleciona Francisco Amaral (2008, p. 90-99): "O conceito e o processo de interpretação submetem-se hoje, porém, a uma revisão crítica, surgindo um novo paradigma por influxo da sociedade pósindustrial. E o Código Civil, enriquecido por princípios e cláusulas gerais, que lhe dão a estrutura de sistema aberto, pode contribuir para um modelo que supere a teoria tradicional de interpretação jurídica, mais condizente com o espírito de renovação metodológica que perpassa pelo Direito Contemporâneo."
} 
Visionário por natureza, Miguel Reale já antevia esse viés, ao ponderar que a perspectiva atual é, portanto, no sentido de que a interpretação dos modelos jurídicos não deve obedecer a puros critérios de lógica formal, nem se reduz a uma análise lingüística, devendo desenvolver-se segundo exigências da razão histórica, entendida como razão problemática ou conjetural $^{155}$.

É o que Menelick de Carvalho Neto aponta como a mudança de paradigmas, através do senso de adequabilidade das regras frente aos princípios baseado num discurso racional e persuasivo. Essa evolução já fora cunhada de outro modo por Anna Cândida da Cunha Ferraz $^{156}$, ao elucidar os processos informais de mudanças da Constituição, entre esses as mutações constitucionais, ao expor:

Os processos formais de mudança da Constituição, nas suas diferentes modalidades, não esgotam, todavia, o fenômeno da contraposição entre constituição normativa e realidade constitucional, ou, mais precisamente, da tensão permanente que se coloca entre a constituição normativa e sua aplicação. A realidade constitucional demonstra, ao contrário, que as constituições rígidas, a par das reformas constitucionais, sofrem outros tipos de mudança. Com efeito, a previsão constitucional de processos de mudança não tem sido suficiente para abranger e resolver toda problemática da tensão entre estabilidade e mudança, entre a estática e dinâmica constitucionais. Até porque não é possível calcular sempre os rumos futuros; tampouco dispor de preceitos escritos para todas as possíveis mudanças e transformações que possam aplicar-se às novas relações jurídicas.

(...)

Destarte, as constituições escritas e rígidas, ainda que estabeleçam processos destinados a permitir sua modificação para acompanhar a evolução dos tempos, não conseguem impedir que, junto a elas ou entre elas, se desenvolva um direito constitucional não escrito, criado a partir dos chamados processos informais de mudança da constituição, genericamente rotulados de mutações constitucionais.

(...)

O reconhecimento do fenômeno, visto e analisado no campo da dinâmica constitucional, se revela, não obstante, como um imperativo determinado pela constante tensão entre constituição escrita e transformações sociais, que não dão tempo de, através de reformas constitucionais, alterar-se o texto para adequá-lo a novas realidades.

(...)

Assim, em síntese, a mutação constitucional altera o sentido, o significado e o alcance do texto constitucional sem violar-lhe a letra e o espírito. "Não é a mutação constitucional um mal em si: depende do alcance e do sentido da mudança. Quando esta, sem ferir a letra da Constituição, respeita sua ratio e seus fins, então se produz uma saudável aproximação da normatividade à realidade constitucional" enfatiza Verdú.

(...)

\footnotetext{
${ }^{155}$ REALE, 1994, p. 112.

156 FERRAZ, Anna Cândida da Cunha. Mutação, reforma e revisão das normas constitucionais. Cadernos de Direito Constitucional e Ciência Política, São Paulo, v. 2, n. 5, p. 5-24, out./dez. 1993, p. 15-18.
} 
De certo modo, essa espécie de poder constituinte remonta àquela regra expressa na Constituição de 1793: "Um povo tem sempre o direito de rever, de reformar e mudar sua Constituição. Uma geração não tem o direito de sujeitar às suas leis as gerações futuras", retro apontada, ou ainda na lição de Montesquieu "De duas maneiras pode um Estado transformar-se ou porque a Constituição se corrige, ou porque ela se corrompe. Por outro lado, as mutações constitucionais decorrem logicamente da própria Constituição, na medida em que se desenvolvem para dar-lhe efetiva aplicação. Com efeito, a Constituição é obra que nasce para ser efetivamente aplicada, sobretudo naquilo que tem de essencial, e o essencial, por vezes, é incompleto, exigindo atuação ulterior, capaz de defini-lo, precisá-lo, resolver-lhe as obscuridades, dar-lhe continuidade e aplicação, sem vulnerar a obra constitucional escrita: trata-se, portanto, de buscar meio efetivos de fazer valer a "vontade" e o "espírito" do constituinte originário.

Ora, se tal assertiva é aplicável até as normas constitucionais, o mesmo vale para a legislação ordinária que deve ser interpretada à luz do arcabouço constitucional. De qualquer forma, deve-se ter em mente que as normas em geral são produzidas em face de uma verdade relativa ao momento de sua criação (dado o pluralismo em suas múltiplas manifestações) ${ }^{157}$ e ordinária aplicação, daí a necessária reflexão do intérprete, em prol do próprio Estado de Direito.

\subsection{Multiplicidade de Centros Normativos - Federalismo}

Como já se observou, a neointerpretação constitucional não abandona os métodos clássicos de interpretação, nem poderia; cuida-se de um processo que agrega novos elementos e confere eficácia aos preceitos diretivos da Carta Republicana; pondera novas formas de elucidar problemas sob um viés metodológico que confere maior ênfase ao resultado e ao prisma macro do sistema.

Sublinhou-se, ainda, que apesar do arrefecimento da força do método dedutivo normativo clássico, o sistema piramidal de normas ainda é preservado, contudo sua interação é de maior dinâmica e complexidade, frente aos princípios e cláusulas dilatórias que encerram posicionamento fluido à luz da sensibilidade do caso concreto e das circunstâncias que sopesam sua aplicação. Enfim, as regras permanecem, embora não imperem de modo onipotente e exclusivo, como outrora, de sorte que ainda permanece ativo o positivismo

\footnotetext{
157 FRANCISCO, José Carlos. Emendas Constitucionais e limites flexíveis. Rio de Janeiro: Forense, 2003, p. 92/93. Prossegue o autor que nada mais democrático que reconhecer essas "veradades" e suas próprias modificações. Defende o autor a necessária adaptação constitucional às mudanças sociais, políticas e jurídicas, sem a ruptura constitucional de uma revolução.
} 
jurídico, porém mais elástico e sensato, isto é, com uma sinergia mais condizente aos comandos humanísticos e à sua própria autocrítica.

Essa constatação epistemológica que sofrera a evolução da Teoria Geral do Direito ao agregar padrões político-sociais ao Direito, afinca-se com sua nova abordagem metodológica ao abandonar uma interpretação estrita da norma sob um método de visão restrito, baseado na análise da norma ao fato, para adotar uma visão macro da norma frente ao ordenamento jurídico, onde o jurista não se limita à análise fria da subsunção do fato à norma, mas a conferir abordagem da conjuntura do ordenamento jurídico - situação que agasalha maior legitimidade à própria definição de Direito e do conceito jurídico em apreciação.

Essa orientação afina-se com a obra de Norberto Bobbio ${ }^{158}$ que reconstrói o problema da definição do Direito na sua localização apropriada, qual seja, na teoria do ordenamento jurídico e não na teoria da norma, para partir daí sua doutrina explicativa. Em suma, a constatação macro é o deslocamento na Teoria Geral do Direito do foco de estudo de visão do estudioso, outrora voltado unicamente para a norma em estudo, agora focado para o conjunto das normas em sistema e a mesma sorte segue a chamada neo-hermenêutica.

Assim, a concepção sistêmica do direito imanente ao positivismo jurídico subsiste, conquanto as características decorrentes da coerência e da completude tenham sido relativizadas por suas próprias engrenagens. Inferiu, assim, o mestre italiano que o ordenamento jurídico não é necessariamente coerente, porque podem existir no âmbito do mesmo ordenamento duas normas incompatíveis e serem ambas válidas ${ }^{159}$ (referindo-se aqui ao critério de vigência).

No federalismo, essa constatação é particularmente intensificada em razão dos multicentros normativos próprios da Federação - sobretudo no âmbito da competência privativa firmada entre os entes federados, porque essas normas são do mesmo nível hierárquico, eis que nesse particular o paradigma de validade é perante a Constituição da

\footnotetext{
${ }^{158}$ Essa conclusão advém do próprio autor e da evolução de seu pensamento, porquanto primeiramente escrevera a obra Teoria da Norma Jurídica e só posteriormente lançou a obra seguinte que completa o seu raciocínio, Teoria do Ordenamento Jurídico. Confessa o autor que a própria definição de Direito só é satisfatória quando se coloca do ponto de vista de ordenamento. (BOBBIO, 1999, p. 22).

${ }_{159}$ BOBBIO, Norberto. O positivismo jurídico: lições de filosofia do direito. Tradução e notas de Márcio Pugliesi, Edson Bini e Carlos Rodrigues. São Paulo: Ícone, 2006, p. 237.
} 
República - mas também na análise da competência concorrente versus a competência privativa.

Recorrer-se-á a exemplos para melhor ilustrar a explanação. Imagine-se a análise interpretativa de uma legislação municipal que busca otimizar critérios e fatores para combater a expressiva poluição da urbe e proíba o trânsito de veículos a diesel em determinados horários e locais, tidos como críticos; ou requeira no processo licitatório de transporte municipal, a utilização de veículos a gás. Poder-se-ia dizer que o Município estaria legislando competência imprópria de trânsito, privativa da União ( $\mathrm{CF}$, art. 22, XI - trânsito e transportes)? Não é o caso, justamente por se tratar de questão afeita a interesse eminentemente local, cujo objeto jurídico é particularmente de âmbito e interesse local, e, portanto, de competência municipal - a capacidade de auto-organanização da urbe. A questão é de grande complexidade, diz respeito à taxionomia das leis, isto é, à sua respectiva fundamentação constitucional na partilha da competência entre os entes federados, cuja tentativa de explanação segue nos itens a seguir.

Factível, portanto, a assertiva de Bobbio de que no caso de concorrência de normas do mesmo nível e contemporâneas não existe dever de coerência por parte do legislador (de entes federados distintos para a competência privativa), enquanto existe para o juiz o dever de resolver a antinomia, de forma a aplicar apenas uma das normas. Simplesmente, no momento em que duas normas antinômicas não puderem ser ambas aplicadas no mesmo caso, ele se encontrará na necessidade de aplicar uma e desaplicar outra ${ }^{160}$. Deveras, a questão debruça-se sobre a eficácia da norma, produto imediato da interpretação jurídica.

Pondera Bobbio ${ }^{161}$ que a coerência é um dever moral, mas não necessariamente uma obrigação jurídica qualificada; não é uma condição de validade, mas sim uma condição para a justiça do ordenamento.

Kelsen acentua essa visão ao observar a descentralização, que é peculiaridade ínsita ao federalismo, e pondera que se as normas de uma ordem jurídica têm diferentes âmbitos espaciais de validade, existe a possibilidade de, para diferentes domínios particulares, vigorarem normas de diferentes conteúdos. Prossegue o estadista:

\footnotetext{
${ }^{160}$ BOBBIO, 1999, p. 112.

${ }^{161}$ BOBBIO, 1999.
} 
A unidade formal do território jurídico não tem de estar ligada à unidade material do conteúdo jurídico. [...] A necessidade de uma diferenciação de conteúdo da ordem jurídica relativamente a diferentes domínios territoriais parcelares pode resultar de diversas causas. Diferenças geográficas nacionais ou religiosas no material a regular juridicamente reclamam consideração através de um desmembramento territorial da comunidade jurídica; e isto tanto mais, quanto maior for a extensão do território jurídico e quanto maior for a possibilidade de diferenciação apresentada pelas relações de vida a normar. ${ }^{162}$

Assim, a missão do legislador é dotada de maior liberdade, pois sua atuação requer obediência e coesão tão somente aos princípios da divisão do poder e das diretrizes constitucionais para expressar as suas prerrogativas federativas, qual seja, a capacidade de autolegislação e auto-organização. Já o aplicador do Direito terá a árdua tarefa de compatibilizar essas normas ao caso concreto, aplicá-las à luz dos princípios constitucionais e da hermenêutica constitucional, de forma a responder diretamente ao plano da eficácia das normas. Visualiza-se, pois, a distinção de uma e outra tarefa, e conseqüientemente a sua linha de abordagem, o que faculta uma visão mais fecunda à divisão dos poderes e peculiar ao sistema federal agasalhado pela Carta Republicana.

Ressalta daí a relevância do intérprete na tarefa de dizer o Direito, pois a sistemática viva do Direito clama por sua concreção prática, de sorte que não se tolera o intérprete constitucional fraco e passivo, como adverte Juarez Freitas. Adverte o jurista que a orientação mecanicista situa-se em desacordo com as reclamações do mundo vivido. Certo, a hierarquização não deve ocorrer nos termos de uma aplicação subjetivista. Há limites formais e substanciais para que se dê vida à ordem jurídica, sendo um destes limites o que deflui do dever de realizar, com a máxima cautela, a "interpretação conforme"163.

Com efeito, a Constituição Federal é o paradigma-mor para o intérprete na análise dos textos legais à luz do caso concreto, dos valores em choque, de sorte que deverá se ater primariamente ao texto constitucional para ordenar as interpretações possíveis, e, se necessário, conferir interpretação conforme a Constituição.

\footnotetext{
${ }^{162}$ KELSEN, 1991.

${ }^{163}$ FREITAS, Juarez. A melhor interpretação constitucional versus a única resposta correta. In: SILVA, Virgílio Afonso da (Org.). Interpretação constitucional. São Paulo: Malheiros, 2005, p. 328.
} 
E, para alcançar legitimidade nessa tarefa, nada mais sensato do que se basear numa interpretação sistemática. Nesse sentido, preleciona Bonavides, faz-se assim suspeita ou falha toda análise interpretativa de normas constitucionais tomadas insuladamente, à margem do amplo contexto que deriva o sistema constitucional. De modo que nenhuma liberdade ou direito, nenhuma organização ou construção do Estado, será idônea fora dos cânones de interpretação sistemática, única apta a iluminar a regra constitucional em todas as suas possíveis dimensões de sentido para exprimir-lhe corretamente o alcance e grau de eficácia ${ }^{164}$.

\subsection{As Antinomias e a Taxionomia na Análise dos Conflitos}

Chama-se de antinomia a situação de incompatibilidade de regramento entre normas. Sua constatação é tão antiga quanto a do ordenamento jurídico, eis que remonta a Justiniano. Inicialmente sua constatação requer uma análise lógica para se deparar de fato com regramentos contraditórios. Tradicionalmente, voltados para a análise infraconstitucional, os juristas apontam três critérios para superá-las ${ }^{165}$, quais sejam: a) o critério cronológico; b) o critério hierárquico; c) o critério da especialidade.

Contudo, no âmbito do Direito Constitucional, tais critérios são insuficientes para a análise de antinomias da legislação dos entes federados. A primeira questão que emerge é justamente a preponderância dos preceitos e diretrizes constitucionais, pois a análise da legislação infraconstitucional deve ser aferida sob o foco constitucional; a leitura da legislação deve ser realizada primariamente sob as lentes dos preceitos constitucionais. Logo, frente à construção constitucional do regime de competências dos entes federados, não há que se falar em critério cronológico para aferir eventual antinomia, nem tampouco o critério hierárquico. Válido, porém, o critério da especialidade para aferir a base constitucional de competência que abriga a lei em foco ou as leis em foco que se entrelaçam.

Enfim, deve-se analisar primariamente a taxionomia da legislação, isto é, a sua respectiva fundamentação constitucional na partilha da competência entre os entes federados.

\footnotetext{
${ }^{164}$ BONAVIDES, Paulo. Curso de Direito Constitucional. 15 ed. São Paulo: Malheiros, 2003, p. 131.

165 Para melhor consulta sobre o tema Cf. BOBBIO, 1999, Cf. ainda FERRAZ JÚNIOR, Tércio Sampaio. Introdução à Ciência do direito: técnica, decisão, dominação. São Paulo: Atlas, 1988, item 4.3.2.2.1.
} 
Assim, o crivo inicial é justamente conferir resposta à indagação: Em qual preceito constitucional de competências tem arrimo o texto legislativo sob análise?

Para se conferir resposta ao feixe de competência constitucional que está em jogo, dois fatores são de essencial análise: i) o objeto jurídico que se está a tutelar pela legislação; ii) a finalidade da legislação frente à especificidade de seus regramentos.

Pelo primeiro critério, deve-se perquirir os considerandos da lei, a necessidade constatada para a legislação e, sobretudo, o grau de interesse em foco para se constatar qual o objeto jurídico preponderante ao tema objeto da legislação; enfim, qual o interesse preponderante em foco.

Já o segundo critério busca elucidar a finalidade da lei, qual o seu intento e sua especialização no universo das normas apto a diferenciá-la de uma ou outra categoria jurídica para a correspondente qualificação constitucional de competência. Esse critério foi sintetizado por André Ramos Tavares ${ }^{166}$ como a especificidade da lei, o objeto específico da lei, cuja resposta deverá nortear a sua classificação/antinomia. Daí, é preciso apartar assuntos díspares que são concomitantes e inter-relacionados a partir da finalidade da lei.

Tavares ilustra o raciocínio com o julgamento da ADIn-MC n. 903-6/MG, cujo objeto foi a Lei n. 10.820 do Estado de Minas Gerais que disciplinava o transporte coletivo intermunicipal de pessoas portadoras de deficiência pelas empresas concessionárias, obrigando as últimas a fazer as adaptações necessárias em seus veículos a fim de facilitar o acesso e a permanência de portadores de deficiência física e dificuldades de locomoção. A querela fora arguida em sede de controle concentrado sob a assertiva de que a matéria em regência referese a trânsito e transporte, própria da União Federal (art. 22, XI). Contudo, o STF acertadamente referendou a constitucionalidade da lei, sob o argumento de que se trata de competência concorrente entre os entes federados, baseado no art. 24, XIV, da Constituição da República, que alberga competência concorrente entre os entes federados para a proteção e integração social de pessoas portadoras de deficiência.

Da análise do voto condutor denota-se que os Ministros focaram a legislação sob exame como instrumento de proteção aos portadores de deficiência, interesse imediato da norma em comento, daí a legitimidade da legislação. Realmente, consoante já frisado, o objeto

${ }^{166}$ TAVARES, 2008, p. 161-188. 
jurídico primário da norma é o principal parâmetro para fincar a taxionomia da norma, e no caso em foco o interesse tutelado pela Lei Mineira n. 10.820 é justamente conferir proteção e integração social aos portadores de deficiência, de sorte que sua abordagem ao trânsito é indireta e mediata, pois traspassa o objeto jurídico primário, qual seja a proteção do portador de deficiência.

Assim, a legislação em comento determina justamente que as empresas concessionárias de transporte municipal implantem os mecanismos necessários para facilitar o embarque e o transporte das pessoas portadoras de deficiência. Logo, a legislação busca por evidente tutelar o portador de deficiência, interesse direto e imediato da lei, ainda que sob o amálgama do transporte intermunicipal que simplesmente fecunda a proteção do portador de deficiência.

A mesma conclusão advém com base na análise do critério "finalidade da lei"; a finalidade da legislação frente à especificidade de seus regramentos, cuja constatação volta-se justamente para o arrimo de normas de proteção e integração das pessoas portadoras de deficiência como resposta à indagação em qual preceito constitucional de competências tem arrimo o texto legislativo sob análise.

De modo correlato, José Afonso da Silva prega que se deve aferir primariamente o interesse predominante da legislação em análise para conferir resposta em qual arrimo de competência constitucional a lei se apóia. Esclarece o constitucionalista que o princípio geral que norteia a repartição de competência entre entidades componentes do Estado Federal é o da predominância do interesse, segundo o qual à União caberão aquelas matérias e questões de predominante interesse geral, nacional, ao passo que aos Estados tocarão as matérias e assuntos de interesse regional, e aos Municípios concernem os assuntos de interesse local ${ }^{167}$. Assim, o princípio da predominância do interesse deve ser aquilatado pelo foco da legislação em comento de forma a melhor visualizar o feixe de competência constitucional que alberga a legislação em exame, a teor dos arts. 22 e seguintes da Constituição Federal.

Tal conclusão encontrada é plenamente compatível com a posição que perquire o objeto jurídico de proteção da norma, conforme exposto.

\footnotetext{
${ }^{167}$ SILVA, 2006, p. 478.
} 
Dos critérios clássicos para a solução de antinomias, adotado neste trabalho, propugnase a preeminência do critério da especialidade, justamente porque harmoniza-se com o critério da preponderância do interesse jurídico tutelado pela legislação frente ao feixe de competências constitucionais. Com efeito, a doutrina é concorde em sustentar que há conflito entre o critério da especialidade e o critério cronológico quando uma norma precedente e especial é antinômica em relação a uma norma sucessiva e geral. Prevalece, daí, o critério da especialidade sobre o cronológico, e, portanto, a norma precedente e especial prevalece sobre a posterior e geral.

Outro exemplo interessante sobre a aplicação do critério de solução de antinomia, agora em sede de confronto com o critério especial versus hierárquico, surge do confronto entre lei municipal e lei federal, justamente quando aquela buscar regular interesse próprio e, assim, tergiversar sobre interesse federal, cujo exemplo advém da regulação de propaganda em espaço aéreo carioca, realizado através da Lei Municipal n. 758/1985.

Como é sabido, tanto a legislação aeronáutica como a relativa à propaganda comercial são privativas da União Federal, ex vi o art, 22, I e XXIX da CF. Contudo, não se pode perder de vista que o Município tem interesse no regramento da segurança, da poluição e do silêncio no espaço da urbe, ainda que aéreo, bem como na tutela dos praianos em face dos voos rasantes na orla carioca. Assim, a regra é a legislação federal atuar como norma superior. Mas a lei municipal poderá suplementar a legislação federal e estadual no que couber aos interesses locais (art. 30, II, da CF), de sorte que seu regramento será especial em relação às demais. Entende-se aqui que suplementar apresenta sentido lato, qual seja, tanto o de suprir a legislação federal e estadual, como de complementar tais regramentos, acrescê-los ou desdobrá-los à luz do interesse local.

Surge, daí, a possibilidade de eventual confronto do critério da especialidade frente ao hierárquico (ambos tidos como critérios fortes), ao passo que a doutrina não firma regra de solução universal para esses casos.

Bobbio sugere que se recorra ao critério fraco, o cronológico, como critério subsidiário para estabelecer a prevalência de um ou outro dos critérios fortes: prevalece o critério hierárquico, isto é, é válida a norma superior geral, se esta for posterior à outra; prevalece, ao contrário, o critério de especialidade, a saber, é válida a norma inferior especial, se for esta a 
posterior. Sintetiza, assim, que uma norma superior geral precedente cede diante de uma norma superior geral sucessiva; uma norma superior geral sucessiva vence no confronto com uma norma inferior especial precedente ${ }^{168}$.

Nesse sentido, eventual regulação municipal referente ao controle de segurança no espaço aéreo rente às praias é válido, desde que posterior ao regramento federal sobre Direito Aeronáutico e especial quanto a esse, e no limite do interesse municipal em foco. Deveras, a Constituição da República menciona que o Município poderá suplementar a legislação federal e estadual no que couber. Decorre daí o signo de ampliar o regramento, mas não de contrariálo - justamente a semântica que se espera do art. 30, II, da Constituição da República.

Inexoravelmente, para a análise e interpretação de tais critérios, surge a questão do método para sua abordagem. Nessa polêmica, concorda-se de início com Canotilho, para quem a questão do "método justo", em direito constitucional, é um dos problemas mais controvertidos e difíceis da moderna doutrina juspubliscística ${ }^{169}$. Realça, contudo, o constitucionalista o caráter complementar de tais critérios. Posto isto, esboçar-se-á alguns métodos que conferem maior sensatez e praticidade na análise de conflitos de legislação no âmbito federativo, cujo âmago de solução reside nas competências constitucionais e na respectiva interpretação constitucional. Tais ponderações são ilustrativas, sem, contudo, ter intuito de esgotar a matéria ou impor posicionamento do melhor método para o estudo em foco.

Nesse contexto, impende considerar que os cânones interpretativos apenas conferem luz ao caminho do operador do Direito, sem contudo impor propriamente o seu caminho, pois são apenas topoi de argumentos; vetores ao raciocínio do jurista, e como tal, esclareça-se, não têm caráter normativo, ou seja, não encerram interpretações de antemão obrigatórias, consoante frisa Böckenförde ${ }^{170}$. De qualquer sorte, são argumentos que auxiliam o hermeneuta ao apontarem critérios que lhe aguçam o raciocínio e a visão de justiça; enfim, conferem maior amparo ao intérprete.

\footnotetext{
${ }^{168}$ BOBBIO, 2006.

${ }^{169}$ CANOTILHO, J. J. Gomes. Direito constitucional e teoria da constituição. 4. ed. Coimbra: Almedina, 2000, p. 1084.

${ }^{170}$ BÖCKENFÖRDE apud MENDES; COELHO; BRANCO, 2007, p. 104.
} 
Juarez Freitas advoga uma visão macro à hermenêutica constitucional, baseada, sobretudo, numa interpretação sobre o método tópico-sistemático das normas constitucionais. Leciona que a Constituição assume-se como uma rede de princípios, de regras e de valores de ordem suprema, cuja função precípua é a de, evitando ou superando antinomias axiológicas, dar cumprimento aos objetivos do Estado Democrático, de maneira substancial.

Nessa perspectiva, pondera o Professor da UFRS que emergem argumentos para robustecer a perspectiva de que a interpretação constitucional é processo, ao mesmo tempo, tópico e sistemático, avesso a automatismos e à vinculação pura. Argumenta que a tópica almeja solução de equilíbrio, um compromisso entre o formalismo e o pragmatismo. Aponta, assim, parâmetros para a interpretação constitucional fincada na perspectiva sistemática quanto à interação das normas e princípios, à luz da busca de soluções pela tópica, sob uma exegese articulada mediante silogismos dialéticos, isto é, a partir de uma escolha (hierarquização) fundamentada, objetiva e imparcial das premissas eleitas. Arrola, daí, diretivas para interpretação, entre essas aquela que prime por uma concepção aberta e coerente do texto constitucional, justamente por ser a Constituição objeto pluralista, a ser compreendida no círculo hermenêutico em suas múltiplas relações ${ }^{171}$.

Dessa leitura ponderamos que em eventual choque de legislações federais e estaduais, a regra é a permanência de ambas as normas, pois o federalismo concebe por essência a convivência de ambas - tratando-se de antinomias aparentes. Assim, respeitadas as normas próprias de cada ente federal, deve-se conferir validade à parêmia do federalismo, segundo a qual as normas estaduais são legítimas para atuar em todas as sendas onde a União Federal não atua explicitamente. Dito de outra forma pelo saudoso Celso Bastos, nada será exercido por um poder de nível superior desde que possa ser cumprido pelo inferior ${ }^{172}$, fórmula que assenta autonomia ideológica ao já estrangulado federalismo brasileiro.

Enfim, presume-se a constitucionalidade da norma do ente federado, até prova motivada em contrário, fiel ao texto constitucional. Vige, pois, a salutar regra da presunção de constitucionalidade das normas, sejam federais, estaduais e municipais - desde que preservada

\footnotetext{
${ }^{171}$ FREITAS, 2005, p. 317-356.

172 BASTOS apud ALMEIDA, 2007, p. 75.
} 
a razoabilidade ${ }^{173}$ de tais normas, frente ao feixe constitucional de competências. Assim, o sistema propugna para que o intérprete admita e se finque em argumentos que confiram validade às normas dos demais entes federados, porquanto o próprio valor federativo prega por isso.

Em outros termos, assim como o intérprete toma a realidade e os valores sociais para fixar o alcance da norma, da mesma forma atuará para fixar os limites de aplicação dos seus preceitos, apto a prevenir os conflitos.

E na linha ora questionada, reputa-se sensatas as seguintes técnicas de interpretação constitucional: primeiramente a interpretação conforme a constituição; o princípio da proporcionalidade que interage com o princípio da concordância prática ou da harmonização; e, por fim, o princípio da correção funcional. Caberá, pois, ao intérprete, fiel à sua perspicácia e argúcia, dosar os valores que a legislação melhor toca, para aferir, a partir de tais diretrizes, os caminhos que o levarão à solução de eventuais conflitos entre os entes federados.

A técnica da interpretação conforme a constituição, além de um topoi de diretriz e argumentação à hermenêutica constitucional, é um instrumento de controle de constitucionalidade $^{174}$. Assim, em face de normas infraconstitucionais de múltiplos significados, deve-se escolher o sentido que as torne constitucionais, de forma a tonalizar a interpretação da norma sob o foco da Constituição da República, de sorte a lê-la sob os influxos dos preceitos constitucionais.

Modernamente, o princípio da interpretação conforme passou a consubstanciar, também, um mandato de otimização do querer constitucional, ao não significar apenas que entre distintas interpretações de uma mesma norma há de se optar por aquela que a torne compatível com a Constituição, mas também que, entre diversas exegeses igualmente

\footnotetext{
${ }^{173}$ Confira que o mesmo argumento impera no âmago de conflito entre Direitos Fundamentais, porquanto inexiste direito absoluto, dada a intersubjetividade dos direitos. Tal raciocínio é defendido por Juarez Freitas, ao ponderar que assim é que se deve interpretar a totalidade dos direitos fundamentais, em nossa Constituição, de maneira proporcional, respeitando a mútua e salutar relativização. Não enfraquece mas, ao contrário, fortalece a totalidade dos direitos fundamentais o fato de serem reciprocamente complementares (...). FREITAS, 2005, p. 345 .

${ }^{174}$ STF, Representação n ${ }^{\circ}$ 1.417/DF, Min. Moreira Alves, RTJ 126/48-72, 66.
} 
constitucionais, deve-se escolher a que se orienta para a Constituição ou a que melhor corresponde às decisões do constituinte ${ }^{175}$.

Atualmente, a interpretação constitucional não se coaduna com um esquema hermético e simplista, próprio de uma visão estritamente formalista e clássica; o texto Maior é essencialmente político, e, como tal, admite uma valoração ética-social.

De fato, é da natureza das constituições abarcarem os seus objetos de um modo simplesmente esquemático, deixando livre o caminho para que a própria experiência vá operando a integração dos variados impulsos e motivações sociais, de que se nutrem tanto a dinâmica política quanto a especificamente constitucional ${ }^{176}$.

Por sua vez, o princípio da proporcionalidade, consoante já exposto linhas acima, representa uma válvula ética ao sistema jurídico para conferir equilíbrio e virtude às normas. Dada a magnitude de seu papel, vale aprofundar suas notas, pois seu alcance filosófico é metajurídico e universal, com relativa superação do positivismo jurídico estrito. Quanto à aplicação do princípio da proporcionalidade, leciona Gebran Neto ${ }^{177}$ :

Diz-se respeitado o princípio da proporcionalidade quando "o meio empregado pelo legislador deve ser adequado e necessário para alcançar o objetivo procurado. $\mathrm{O}$ meio é adequado quando com seu auxílio se pode alcançar o resultado desejado: é necessário, quando o legislador não poderia ter escolhido um outro meio, igualmente eficaz, mesmo que não limitasse ou limitasse de maneira menos sensível o direito fundamental" aresto da Corte Constitucional de Karlsruche, citado por Bonavides.

(...)

O fundamento constitucional do princípio da proporcionalidade pode ser extraído, segundo parte da doutrina - que segue a linha do Direito Alemão - implicitamente do texto constitucional, como um princípio não-escrito inerente ao Estado de Direito. Outra parte da doutrina nacional - com inspiração no direito norte-americano decorre da cláusula do devido processo legal substantivo.

(...)

PROPORCIONALIDADE EM SENTIDO ESTRITO. Os meios eleitos devem manter-se numa relação de razoabilidade com o resultado perseguido, ou seja, somente deve ser adotada a restrição no limite adequado e indispensável ao benefício que o resultado gera para a coletividade. Em suma, deve haver uma valoração e uma ponderação recíproca de todos os bens involucrados, tanto os que justificam o limite como os que são afetados por eles, os quais exigem sejam consideradas todas as circunstâncias relevantes do caso.

\footnotetext{
${ }^{175}$ MEDEIROS apud MENDES; COELHO; BRANCO, 2007, p. 113.

${ }^{176}$ MENDES; COELHO; BRANCO, 2007, p. 99.

177 GEBRAN NETO, João Pedro. A aplicação imediata dos direitos e garantias individuais - a busca de uma exegese emancipatória. São Paulo: Revista dos Tribunais, 2002, p. 113-117.
} 
A projeção do princípio da proporcionalidade no âmbito constitucional é intensa, conforme tem pronunciado iterativamente o Supremo Tribunal Federal e outras tantas Cortes Constitucionais. Seu resultado deita proximidade ao princípio da concordância prática, pois frente a uma situação de valores constitucionais protegidos, propugna por adotar solução que otimize a realização de ambos, de forma a cortar excessos que ultrajem a preservação do núcleo essencial do direito de qualquer deles.

Justamente, fiel a tais princípios, o hermeneuta deverá conferir interpretações principiológicas para buscar a solução de conflitos, inclusive com base na legislação que rege os institutos.

\subsection{Limites Objetivos, um Ponto de Equilíbrio}

Algumas observações são necessárias para que a hermenêutica jurídica ora defendida mantenha o equilíbrio do sistema. Como já frisado, o atual estágio da hermenêutica constitucional trabalha com a relação dialética entre sujeito/objeto, e daí a riqueza do conhecimento dessa relação, pois fertilizada pela pré-compreensão do intérprete ditada pelo dinamismo da vida (dos objetos) sobre o Direito. É nesse perfil que a hermenêutica evolui das entranhas do cânone da separação dos Poderes, signo em evolução condizente com a atual Constituição e o momento político que a fundou.

Assim, por amor à coesão política ora invocada, a interpretação jurídica constitucional é atividade operada por toda a sociedade, até por impulso do regime democrático, de forma que não se denota razoabilidade na interpretação única provinda do Judiciário. Emerge, daí, a relevância da riqueza dos diálogos provindos das diferentes áreas da sociedade em prol de uma melhor deliberação jurídica, como o instituto da audiência pública no âmbito processual, o amicus curiae, entre outras participações heterodoxas que enriquecem a interdisciplinaridade de questões político-jurídicas. Justamente por isso, o princípio da separação de Poderes não é tido como vulnerado, mas sim enriquecido através de uma deliberação democrática e pluralista condizente ao nosso regime político e ao próprio Estado de Direito.

Nesse mesmo sentido é a posição de Daniel Sarmento ${ }^{178}$ ao ponderar sobre os riscos do neo-constitucionalismo quanto ao pendor judicialista - de forma que o posicionamento supra

\footnotetext{
${ }^{178}$ SARMENTO, 2009, p. 95-133.
} 
procura justamente arrefecer essa faceta, dada a contribuição dos demais Poderes e dos demais atores institucionais, como a $\mathrm{OAB}$, o Ministério Público, as Universidades e entidades científicas, entre outros, na participação da interpretação constitucional.

Ora, o regime democrático prega na sua essência a participação da sociedade na gestão da res pública, e, consequentemente, até nos contornos da interpretação constitucional - tanto porque no governo do povo e pelo povo esse é o fiscal dos fiscais. Assim, torna-se natural ampliar o espectro dos legitimados às discussões constitucionais, até pela busca de uma postura mais objetiva e crítica ${ }^{179}$.

Tanto porque, como assinala Aulis Aarnio, no âmbito do Direito, o intérprete não pode pretender um resultado que só a ele satisfaça, até porque a interpretação jurídica é essencialmente um fenômeno social e, assim, deve alcançar um nível de aceitabilidade geral $^{180}$.

Outro importante risco à hermenêutica constitucional é a preocupação quanto à sua objetividade - frente à participação ativa do intérprete - de forma que resta imperativo o cuidado ao subjetivismo destorcido na interpretação, ocorrido mediante a generalização equivocada dos textos.

De um lado tem-se, como um dos eixos centrais do pensamento constitucional hodierno, a reabilitação da racionalidade prática no âmbito jurídico, com a articulação de complexas teorias da argumentação, que demandam muito dos intérpretes e dos juízes na justificação de suas decisões. De outro lado, tem-se um sistema fragilizado quanto à sua segurança, dada a "dogmática fluida" dos múltiplos princípios que se inter-relacionam. Aqui é o alerta para que as ponderações de valores não maculem a objetividade natural do sistema.

Por isso, chama-se a atenção do intérprete - seja ele o advogado, o administrador, o parlamentar ou o juiz - para arrefecer parâmetros eloqüentes na hermenêutica constitucional que exageram na relativização de regras. Tanto porque a preponderância dos princípios sobre a regra só ocorre em circunstâncias excepcionais quando vulnerado diante das circunstâncias

\footnotetext{
${ }^{179}$ Há significativos trabalhos acadêmicos no âmbito anglo-saxão sobre as vantagens de modelos teóricos que favoreçam diálogos entre diversos órgãos e instituições na interpretação constitucional. Cf. TRIBE, Laurence; DORF, Michael. Hermenêutica Constitucional. Tradução de Amarílis Birchal. Belo Horizonte: Del Rey, 2007. TUSHNET, Mark. Weak Courts Strong Rights: Jucidial Review and Social Welfare Rights in Comparative Making Law. Princeton: Princeron University Press, 2008. HÄBERLE, 2004.

${ }^{180}$ AARNIO apud MENDES; COELHO; BRANCO, 2007, p. 115.
} 
concretas o núcleo essencial do direito firmado no princípio jurídico e o senso de adequabilidade ao Estado de Direito.

Deve-se, ainda, analisar o texto de forma neutra. Deixar que a norma exponha seu sentido semântico para equacioná-la frente às demais normas. Tribe e Dorf anotam essa preocupação com a generalização equivocada no seu livro On reading the Constitution. Salientam que uma forma de se dirigir para a identificação do valor central ou valores implícitos em uma cláusula específica da Constituição é acomodar esta cláusula entre a estrutura global do resto da Constituição, para então questionar se as práticas que são ordenadas ou proscritas pela Constituição pressupõem essa visão da norma ${ }^{181}$.

A generalidade do raciocínio interpretativo deve, pois, guardar sintonia com o texto, de forma a conectar o caso objeto de interpretação aos princípios constitucionais que efetivamente se aplicam ao caso sob análise. Assim, uma vez frente a conflitos de ordem normativa entre diferentes entes federados, a tarefa do intérprete é de conectar as cláusulas de competência dos entes federados sob a ótica da legislação em cotejo, para assim aferir o valor constitucional federativo de maior magnitude, em sintonia, ainda, com as garantias fundamentais que a Carta Republicana fundou.

A generalização do intérprete deve assim basear-se numa concepção imparcial dos fatos, fiel aos métodos supra apontados (sem a ingenuidade da hierarquia entre esses), mediante interação dialética de tais métodos com um olhar aberto para a repercussão de sua aplicação. Deve-se ter em mente o caráter abstrato dos fatos para não ter uma visão míope e sob pena de incorrer em equívocos interpretativos.

Tribe e Dorf descrevem o que entendem por um grande equívoco interpretativo baseado na generalização destorcida do aplicador do direito sobre o direito da privacidade, conforme apontam na análise de um caso concreto. Criticam, assim, o caso Bowers v. Hardwick $^{182}$, baseado na opinião majoritária dos votos em que a Corte sustentou que o Estado

\footnotetext{
${ }^{181}$ TRIBE; DORF, 2007, p. 33.

${ }^{182}$ From Wikipedia, the free encyclopedia Bowers v. Hardwick, 478 Unidet States Report (1986), was a Supreme Court of the United States decision that upheld the constitutionality of a Georgia (US state) Sodomy law that criminalized Oral Sex and Anal Sex in private between consenting adults when applied to homosexuals. Seventeen years later the Supreme Court directly overruled Bowers in Lawrence v. Texas, 539 U.S. 558 (2003), and held that such laws are unconstitutional. In overruling Bowers v. Hardwick, the 2003 Court stated that "Bowers was not correct when it was decided, and it is not correct today. No vernáculo: Fonte: Wikipedia
} 
da Geórgia poderia criminalizar a sodomia consensual adulta em particular - ao menos quando tivesse havido conduta homossexual - sem dar nenhuma razão para a repulsa moral para com este ato ${ }^{183}$.

A observação que emerge é justamente quanto ao nível de generalização utilizado pelo intérprete para desdobrar o caso, de forma que deverá se utilizar da generalização mais condizente ao Direito Constitucional em foco, em especial os direitos fundamentais. Há de se concordar com Tribe e Dorf quanto o equívoco de se visualizar o caso Bowers v. Hardwick a partir do estreito ângulo do Direito Penal que criminalizava a prática de sodomia entre homossexuais, como o fez o Juiz White, o que não se mostra razoável, pois a questão subjacente ao caso é justamente a preservação do direito de privacidade - de matriz constitucional, cuja análise precede aquela, e, como apontado, identifica-se com o valor central da Constituição em discussão.

Assim, deve-se ter em mente a assertiva básica que a Constituição funda, condiciona e dirige a interpretação da legislação ordinária, pois essa é imbuída dos valores e diretrizes constitucionais, ao passo que a recíproca não é verdadeira, pois a Constituição não há que ser lida de baixo para cima, isto é, das leis para a Constituição, mas sim da Constituição para as leis.

Esse exemplo ilustra a importância dos níveis de abstração para descrever e assim analisar os problemas jurídicos. Alertam Tribe e Dorf que as caracterizações são o ponto de

enciclopédia Bowers v. Hardwick, 478 EUA (1986) foi o aresto judicial da Suprema Corte Americana que sufragou a constitucionalidade de uma lei do Estado de Georgia que criminalizava a sodomia entre adultos homossexuais. Após dezessete anos, a mesma Suprema Corte retificou sua posição no caso Lawrece v. Texas, 539 EUA 558 (2003) e considerou inconstitucional. Ao desconsiderar a orientação do caso Bower v. Hardwick em 2003, a Corte afirmou que "o Bowers não foi correto quando decidido, e não é correto hoje." - tradução livre.

183 TRIBE; DORF, 2007, p. 69. Prosseguem os autores na crítica do julgado da Suprema Corte Americana quanto ao reconhecimento dos direitos constitucionais não enumerados, ao observarem que a Corte parece permitir uma substancial erosão destes direitos, ao reconhecê-los em determinados casos e negá-los em outros. Por quatro votos contra cinco a Suprema Corte se recusou a defender o direito à tutela da privacidade da atividade sexual nesse caso. Apontam os autores que ao decidir da forma como foi feito no caso Hardwick, a Corte desenhou sozinha uma divisória instável entre alguns tipos de privacidade e outros. Essa divisória não oscila sobre a existência de um comércio, nem sobre a coerção, e nem sobre danos visíveis, mas é uma linha que oscila sobre aprovação popular. Mais preocupante ainda que o resultado do caso Hardwick, é a falha cometida pela Corte ao oferecer uma explicação razoável para a linha divisória que ela desenhou. A Corte acabou formatando uma distinção entre as intimidades que tradicionalmente eram protegidas pelas decisões de contracepção, e as intimidades menos tradicionais - ao menos nos casos que envolviam homossexuais - que entendeu serem o tema, no caso da Geórgia. 
partida para as análises, de forma que tanto a corrente majoritária como a minoritária dos votos supra citados propõem perguntas diferentes para a questão, e, assim, não é de se surpreender que eles encontrem respostas diferentes ${ }^{184}$.

Em outros termos, a observação que se lança é que a abstração do problema ou do conflito não poderá ser tendenciosa, mas neutra aos fatos e valores constitucionais. Deverá se apresentar conectada ao fulcro constitucional subjacente à questão, seja na sua descrição fática, seja na sua conexão lógica, pois somente à luz da crítica construtiva erigir-se-á uma base sensata e neutra de abstração para melhor solver o problema.

Note-se que a própria pluralidade de valores acolhidos pela nossa Constituição da República requer a admissão de diferentes métodos interpretativos para, a partir da crítica, discernir qual a interpretação mais condizente com o valor constitucional em foco. Enfim, a racionalidade da interpretação tem como substrato filosófico o equilíbrio do interprete e das suas valorações, como já observava Aristóteles ${ }^{185}$ na chamada filosofia da virtude do equilíbrio.

Essa visão também pode ser constatada segundo o princípio da totalidade, salientado desde os romanos como o cânone da coerência de sentido entre as investigações hermenêuticas. Este cânone vem esclarecer as inter-relações e a coerência existente no seio dos elementos individuais do discurso, tal como sucede com qualquer manifestação do pensamento e sua relação mútua com o todo que integram. É essa relação dos elementos entre si e com o seu todo comum que permite o esclarecimento e a elucidação recíproca das formas significativas na relação entre o todo e as suas partes, e vice-versa. ${ }^{186}$

De outro modo, anota Daniel Sarmento que, certamente, uma visão equilibrada da Teoria do Direito com uma visão que conecte o Direito com exigências de justiça e moralidade crítica, sem descartar a importância das regras e da subsunção, pode contribuir para o aperfeiçoamento do Estado Democrático de Direito no Brasil. O mesmo não se aplica

\footnotetext{
184 TRIBE; DORF, 2007, p 97. Prosseguem os autores que a pergunta feita pela maioria, responde a si mesma. Descrever o direito reivindicado em termos específicos - nesse caso o "direito de praticar sodomia homossexual"- é desconectá-los dos direitos previamente estabelecidos.

${ }^{185}$ Vide no inglês "Golden Mean", The Nicomanchean Ethics, a virtude do equilíbrio no pensamento de Aristóteles. Fonte: Wikipedia Enciclopédia no sítio virtual: <http://en.wikipedia.org/wiki/Nicomachean_Ethics>

${ }^{186}$ BLEICHER, [s.d.], p. 87-88. Refere-se o autor ao jurista romano Celso. Prossegue seu raciocínio na seguinte diretriz: o sentido do todo tem de provir dos seus elementos individuais e um elemento individual tem de ser entendido em referência ao todo completo e penetrante do qual faz parte.
} 
às concepções mais radicais do neoconstitucionalismo ${ }^{187}$, daí a razão no pensamento conservador que prega que a interpretação não poderá levar a crises institucionais.

Enfim, o que se procura demonstrar é que a contribuição da Teoria da Argumentação apontada por Gadamer ${ }^{188}$ - onde releva distinção entre o texto enunciado, objeto de interpretação e o seu resultado, a norma de decisão - procura conferir funcionalidade ao próprio sistema. Assim, ter-se-á condições de avaliar o papel vivo do Direito na realização de sua função no âmbito da sociedade, e não como um sistema estático de regras e princípios. Porém, os limites da interpretação decorrem do próprio programa normativo (e não valorativo).

Assim, o principal parâmetro para os limites da interpretação consiste na exigência de que toda e qualquer interpretação constitucional seja compatível com a amplitude de sentidos projetada pelo texto do enunciado. Esse é, pois, ao mesmo tempo, o ponto de partida do processo hermenêutico e o mais expressivo balizador da adequação de seus resultados. ${ }^{189} \mathrm{E}$, para tanto, o intérprete deve utilizar os vários métodos de interpretação para buscar os resultados condizentes à dogmática jurídica, vínculo que delineia a margem admissível e define os parâmetros para a interpretação, de forma que o intérprete não se perca no seu próprio relativismo.

Ora, se de um lado não é admissível se ater exclusivamente ao texto enunciado, tanto porque o texto é apenas o principal parâmetro que interage com o universo jurídico e fático, de outro lado o intérprete aplicador não pode substituir os parâmetros do texto enunciado como uma criação da norma pelo próprio intérprete.

Essas assertivas são próprias do positivismo moderado que admite sim a interação do intérprete-aplicador (sujeito) no texto enunciado (objeto da interpretação), e reconhece, assim, certa discricionariedade em normas abertas do Direito Constitucional, nas cláusulas dilatórias (que encerram comportamento éticos) e na interação dos princípios. Contudo essa margem de interpretação é balizada pela própria Dogmática do Direito, e não pelos valores subjetivos do intérprete, mas, sim, pelo objetivismo dialético do sistema, baseado na interação compatível da

\footnotetext{
${ }^{187}$ SARMENTO, 2009, p. 133.

${ }^{188}$ BLEICHER, [s.d.], p. 181.

${ }^{189}$ RAMOS, 2009, p. 136. A preocupação do autor no seu trabalho acadêmico é justamente conferir limites ao chamado ativismo judicial.
} 
amplitude de sentidos projetada pelo texto norma e a consciência jurídica geral firmada na ratio da fundamentação (na autoridade dos argumentos jurídicos, políticos e filosóficos; e não no argumento da autoridade).

\subsection{Peculiaridades Interpretativas das Normas Municipais no Federalismo}

Conforme já explicitado no Capítulo da Competência Municipal, a tônica lançada pelo constituinte para legitimar a competência municipal é justamente a referência ao interesse municipal a regrar o assunto em pauta. A notoriedade do interesse municipal alicerça, pois, a legitimidade da legislação municipal e sua interação com as demais normas, e, consequentemente, com a interpretação e solução de eventuais conflitos.

A interação de normas é consequência inerente ao federalismo, pois apresenta diversas fontes normativas que interagem, de sorte que alguns assuntos têm ingerência de legislações federais e municipais ou estaduais e municipais. Pois, como é sabido, raramente há interesse exclusivo de um ente federado num determinado assunto, posto que o interesse de um ente político reflete direta ou indiretamente nos outros níveis de Governo. Mas, para se firmar o interesse municipal, nos termos do art. 30, inc. I, da $\mathrm{CF}$, é preciso que o interesse do Município se sobreponha aos interesses dos demais entes políticos, por razões fáticas e jurídicas legítimas.

Em outros termos, exige-se a preponderância da envergadura do interesse municipal sobre os demais entes federados, para se ter como legítima a legislação municipal sobre o assunto.

Essa assertiva é melhor ilustrada através de um exemplo. Cuida-se de interessante questão sobre a legitimidade da legislação municipal ao regrar o trabalho aos domingos no âmbito do comércio municipal. A Lei Federal $n^{\circ}$ 10.101/2000 encerrou a discussão ao determinar em seu artigo $6^{\circ}$ a observância da legislação municipal sobre o assunto. A técnica do legislador apaziguou a situação de insegurança jurídica que reinava sobre o assunto. Nada mais sensato, pois cabe ao povo do Município determinar a viabilidade da abertura do comércio aos domingos, matéria que trata preponderantemente o interesse da comuna. Diz a Lei Federal (grifei): 
Art. 6: Fica autorizado, a partir de 9 de Novembro de 1997, o trabalho aos domingos no comércio varejista em geral, observado o art. 30, inciso I, da Constituição.

Parágrafo Único: O repouso semanal remunerado deverá coincidir, pelo menos uma vez, no período máximo de quatro semanas, com o Domingo, respeitando as demais normas de proteção ao trabalho e outras previstas em acordo ou convenção coletiva.

O artigo 30, inciso II, da Constituição, determina que compete ao Município suplementar a legislação federal e estadual no que couber. Em termos dogmáticos, a disposição representa ampliação da competência concorrente para o âmbito municipal, desde que presente o interesse local para o assunto, pois não é razoável o Município suplementar a legislação sobre assuntos estranhos ao seu interesse. Deveras, a técnica da competência concorrente acresce a participação dos demais entes políticos ao Estado de Direito e à própria democracia exercida com mais plenitude pela participação municipal, porquanto aqui a voz do povo, fonte primária do poder, é mais intensa e imediata, de sorte que se pode até corrigir discrepâncias regionais, aparando assimetrias de fato, dada a rica peculiaridade nacional, seja no âmbito geográfico (rede fluvial, estiagem etc) ou cultural. Observa-se, contudo, que se deve preservar as diretrizes da legislação federal e estadual.

Assim, o caráter supletivo da legislação municipal tem como pressuposto a observância da legislação federal e estadual quando a questão interagir com matéria sujeita à competência concorrente dos demais entes federados.

A propósito, veja curiosa celeuma que se instaurou entre o Governo Municipal e o Estadual de São Paulo, quanto ao saneamento básico (particularmente sobre a SABESP) da região metropolitana de São Paulo, dada a discrepância de normas estaduais e municipais referentes ao rodízio de água que afeta a região metropolitana de São Paulo. O Município interveio sobre a política em andamento para tomar as rédeas do assunto.

Entretanto, a intervenção municipal é medida excepcional, de sorte que as normas municipais não poderão se sobrepor às estaduais; as normas municipais poderão integrar-se às estaduais, ou mesmo exigir maior racionamento dos seus munícipes, dado o interesse jurídico na preservação de um mínimo d’água nos mananciais; por isso, as normas municipais não poderão suspender ou atenuar o rodízio em afronta às normas estaduais, diante da envergadura do interesse estadual sobre o assunto e das próprias fontes de abastecimento provirem de diversos municípios. Enfim, cuida-se de interesse predominantemente do Estado ou, se 
firmado em lei complementar, interesse da Região Metropolitana de São Paulo, em face do planejamento e interesse comuns.

Já quanto ao horário de funcionamento de farmácias, o STF posicionou-se no sentido de se tratar de interesse predominantemente municipal, e, como tal, propício à competência privativa dos Municípios (art. 30, I, da CF) para estabelecer o horário de funcionamento das farmácias, como o do comércio em geral, consoante dita a Súmula 645 do STF: É competente o Município para fixar o horário de funcionamento de estabelecimento comercial. Contudo, o mesmo não se aplica às instituições bancárias, porquanto presente interesse nacional sobre o assunto - dada as transações bancárias interferirem diretamente em nível nacional ${ }^{190}$.

Já quanto às determinações municipais que determinam que as instituições financeiras devam assegurar bebedouro, sanitário ou assentos nos estabelecimentos bancários, essas normas são constitucionais, pois não interferem nos assuntos típicos de uma instituição financeira, como a política de câmbio, crédito, ou organização estrutural de uma instituição financeira, consoante determinação do STJ. Considerou-se que essas normas são apenas regras direcionadas ao melhor atendimento do usuário/cliente ${ }^{191}$. Como se frisou, deve-se aferir a envergadura do interesse em jogo para interpretação da norma em cotejo com seu arrimo de competência.

Por sua vez, a prerrogativa municipal de firmar o ordenamento territorial deve atender os princípios constitucionais, entre esses, o da livre concorrência, daí ser vedado ao Município interditar a abertura de novo estabelecimento comercial do mesmo ramo econômico em determinada área, consoante estipula a Súmula 646 do $\mathrm{STF}^{192}$. Por outro lado, cabe ao Município fixar as condições de localização para a abertura de instituições de saúde, creches e de outras instituições de interesse público, bem como determinar as divisões dos bairros em residenciais, comerciais e industriais, para assim satisfazer os interesses da urbe.

Outra interessante polêmica de conflito entre lei estadual e lei municipal e respectiva sugestão interpretativa para a solução de conflitos é a que segue.

Cuida-se do choque entre a legislação estadual e municipal. Ambas regulamentam a mesma matéria, a queima da cana-de-açúcar no Estado de São Paulo. Enquanto a Lei Estadual

\footnotetext{
${ }^{190}$ Consoante assentou o STF no RE 130.683, DJ de 9-10-1992.

${ }^{191}$ RMS n. 21.981, Relatora Min. Eliana Calmon.

192 Ofende o princípio da livre concorrência lei municipal que impede o estabelecimento de estabelecimentos comerciais no mesmo ramo em determinada área.
} 
Paulista n. 11.241/2000 admite a queima de cana-de-açúcar com algumas restrições, a Lei Municipal de Botucatu n. 4.446/03 veda completamente a queima do canavial no âmbito de sua circunscrição territorial.

Irresignados, os empresários rurais ingressaram na Justiça e impugnaram a legislação municipal, através de Ação Direta de Inconstitucionalidade n. 146.999-0 perante o Tribunal de Justiça de São Paulo, sob o argumento de não se cuidar de interesse municipal o regramento da questão; aduzem ainda afronta à legislação estadual, que admitia a queima com algumas reservas, cujo eixo de competência constitucional advém do art. 24, VI, da Constituição da República, em sede de competência concorrente entre os entes federados, nos seguintes termos:

\footnotetext{
Art. 24. Compete à União, aos Estados e ao Distrito Federal legislar concorrentemente sobre:

VI - florestas, caça, pesca, fauna, conservação da natureza, defesa do solo e dos
} recursos naturais, proteção do meio ambiente e controle da poluição;

\section{(...) \\ $\S 1^{\circ}$. No âmbito da legislação concorrente, a competência da União limitar-se-á a} estabelecer normas gerais.

$\S 2^{\circ}$. A competência da União para legislar sobre normas gerais não exclui a competência suplementar dos Estados.

$\S 3^{\circ}$. Inexistindo lei federal sobre normas gerais, os Estados exercerão a competência legislativa plena, para atender a suas peculiaridades.

$\S 4^{\circ}$. A superveniência de lei federal sobre normas gerais suspende a eficácia da lei estadual, no que lhe for contrário.

Particularmente, entende-se que o Município também pode legislar sobre a matéria desde que presente seu interesse local. Ora, o interesse em pauta é justamente a qualidade do ar do Município, que resta particularmente comprometido com as queimadas. Entende-se que há legitimidade na legislação municipal ao menos até as raias da repercussão da urbe.

Nesse sentido, foi a decisão do Tribunal de Justiça de São Paulo que julgou improcedente a Adin que impugnava a legislação municipal. Contudo, em sede de Ação Cautelar contra a decisão do TJSP (AC 2316), a Ministra Relatora Ellen Gracie, por meio de 
liminar, determinou a suspensão da eficácia da legislação municipal, sob o argumento de que a lei estadual prevalece sobre a municipal.

Data venia, parece que em sede de competência concorrente no âmbito do meio ambiente vale, na concorrência de normas estaduais e municipais, a norma mais benéfica ao interesse protegido (o meio ambiente) - na prática a norma mais rigorosa de proteção ${ }^{193}$. Ademais, também o Município é compelido a proteger o meio ambiente e combater a poluição em qualquer de suas formas, ex vi do art. 23, VI, da Constituição Federal. E, como tal, somente através da aplicação da norma mais rigorosa de proteção ter-se-á o atendimento de todas as normas. Nesse sentido, leciona Luiz Alberto D. Araújo, ao apontar que em sede de competência concorrente imprópria, as três ordens federativas exercem competência para proteção ambiental $^{194}$.

\footnotetext{
${ }^{193}$ Conforme já explicitado no Capítulo da Competência Concorrente.

194 ARAÚJO; NUNES JÚNIOR, 2009, p. 193. Nesse sentido, lança o constitucionalista o seguinte exemplo: "Veja-se, a pretexto de ilustração, as competências comuns de proteção ao meio-ambiente e preservação de florestas (incisos VI e VII do art. 23 da CF). Figure-se a hipótese de que, no exercício dessas competências comuns, leis federal, estadual e municipal disponham sobre uma faixa de proteção florestal da Mata Attântica. Neste exemplo, a lei federal estabeleceria a proteção da vegetação nativa a partir de $100 \mathrm{~m}$ do nível do mar, a lei estadual a partir de $140 \mathrm{~m}$ e a municipal a partir de 70. Qual delas deveria ser aplicada? Sem dúvida nenhuma, as três. Assim, a vegetação estaria protegida a partir de $70 \mathrm{~m}$ do nível do mar, pois a observância da legislação mais rigorosa implicaria automaticamente a dos demais comandos normativos." Tal constatação na prática é observada na Lei de Zoneamento Urbano, no seu art. $4^{\circ}$, II e III determina a observância da legislação mais rigorosa, de forma a observar os preceitos estaduais e municipais, para o loteamento. Entendimento idêntico sobressai do art. $4^{\circ}, \S 2^{\circ}$, do Código Florestal:
}

Art. $4^{o}$ A supressão de vegetação em área de preservação permanente somente poderá ser autorizada em caso de utilidade pública ou de interesse social, devidamente caracterizados e motivados em procedimento administrativo próprio, quando inexistir alternativa técnica e locacional ao empreendimento proposto.

$\S 1^{o}$ A supressão de que trata o caput deste artigo dependerá de autorização do órgão ambiental estadual competente, com anuência prévia, quando couber, do órgão federal ou municipal de meio ambiente, ressalvado o disposto no $\$ 2^{\underline{o}}$ deste artigo.

$\S 2^{\circ}$ A supressão de vegetação em área de preservação permanente situada em área urbana, dependerá de autorização do órgão ambiental competente, desde que o município possua conselho de meio ambiente com caráter deliberativo e plano diretor, mediante anuência prévia do órgão ambiental estadual competente fundamentada em parecer técnico. 
Essa é a assertiva que mais condiz com o objeto jurídico da norma, a proteção ao meio ambiente $^{195}$, valor conferido e sujeito à proteção dos três entes federados, a teor do art. 23, VI, e 225 da Constituição da República.

Assim, as normas federais, a teor do parágrafo $4^{\circ}$ do art. 24 da $\mathrm{CF}$, quando normas gerais prevalecem em caso de conflito com as demais normas - desde que não invadam especificidades ou detalhes de interesse próprios de outro ente federado, semântica do art. 24, $\S 1^{\circ} \mathrm{da} \mathrm{CF}$, conforme explicitaremos melhor a seguir.

Nessa toada, propugna-se que o Município tem de fato legitimidade para regrar o assunto, ao menos até os limites da urbe, certamente atingida pela fuligem, partículas queimadas de cana. E, caso houvesse superação desse limite pela legislação municipal (supondo lei em descompasso com a razoabilidade), em contraste com a lei estadual - ou mesmo se houvesse lei federal que permitisse o uso da queimada - lança-se a possibilidade de se conferir interpretação baseada no princípio da concordância prática, e na interpretação conforme para o fim de limitar a eficácia e validade da legislação municipal tão somente à zona urbana municipal - compreendida essa toda região distante até 3 quilômetros de uma escola primária ou posto de saúde, reconhecida como zona urbana pela lei municipal.

Essa fixação advém da legislação tributária que determina a incidência do IPTU (e não do ITR) nas áreas distantes até três quilômetros de uma escola primária e que contenham aos menos duas das características descritas no art. 32 do Código Tributário Nacional.

Eis a razoabilidade concretizada. Em sede de antinomias insuperáveis como a presente, o intérprete pode buscar a solução com base na própria legislação de regência e, assim, mitigar os efeitos de uma das regras, em sintonia com o princípio da correção funcional, segundo o qual o constituinte estabelece estrutura de equilíbrio na correlação de competências, de forma que o intérprete deverá buscar a solução que melhor acolha esse modelo organizatóriofuncional.

\footnotetext{
195 Também nesse sentido é o entendimento de CAVEDON, Fernanda de Salles et al. Função ambiental da propriedade urbana e áreas de preservação permanente: a proteção das águas no ambiente urbano. In: CONGRESSO INTERNACIONAL DE DIREITO AMBIENTAL, 7º, 2003, São Paulo. Direito, água e vida = Law, water and the web of life: 2 a 6/06/2003. Antonio Herman Benjamin (Org.). São Paulo : Imprensa Oficial do Estado de São Paulo , 2006, v. 2, p. 173-195.
} 
Como já se disse, atualmente, já não há espaço ou legitimidade para prender o intérprete no quadrado indevassável do enunciado do texto, sob o pálio da dimensão binária a que o positivismo exacerbado condenou o jurista. Não! Os princípios, os valores constitucionais, impulsionados pela interpretação hodierna, romperam essa visão míope, pois os princípios constitucionais situam-se ao mesmo tempo na base e no ápice do ordenamento, vale dizer, são fundamentos e cúpula do sistema, consoante prega Juarez Freitas ${ }^{196}$. Contudo, a solução para a superação da antinomia há de ser aferida na própria legislação positivada, nos princípios ou nos desdobramentos dos institutos do Direito.

\subsection{Antinomias e a Competência Concorrente}

No âmbito da competência concorrente, os comandos constitucionais lançam duas ordens às normas federais (art. $24, \S 1^{\circ}$ e $\S 4^{\circ}$ ), quais sejam: a) a competência da União limitar-se-á a estabelecer normas gerais; b) a sobreposição das normas federais frente à legislação estadual no que lhe for contrário.

Diante de tais preceitos, resta fixado que, em sede de legislação geral, a normas federais são superiores, pois suspenderão a eficácia da legislação estadual que disponha em contrário. Contudo, pende a polêmica sobre o que se entende por normas gerais.

Primeiramente, enfatiza-se que esse limite não foi fixado satisfatoriamente pela jurisprudência, justamente por se cuidar de conceito eminentemente fluído. Tem-se assistido, em razão de tal mecanismo, uma forma de exasperação das forças federais sobre os demais entes federados, o incremento das chamada forças centrípetas, conforme já assinalado linhas atrás $^{197}$.

Talvez justamente em razão dessa insegurança jurídica no âmbito da competência concorrente, a Alemanha tenha optado por firmar uma Reforma Constitucional, vez que seu ordenamento também detinha cláusulas constitucionais nesse mesmo sentido, as quais inspiraram nosso constituinte. Nota-se, pois, as dificuldades do tema para conferir segurança e

\footnotetext{
${ }^{196}$ FREITAS, 2005, p. 326.

${ }^{197}$ Vide item 2.7.2 do trabalho - Sistemática e funcionamento da Competência Concorrente Legislativa.
} 
autonomia aos demais entes federados no regramento de disposições próprias e peculiares ao seu interesse. E nesse sentido, lança-se como sugestão o aprimoramento de tais disposições, em sede de projeto de Emenda Constitucional, ora reivindicada pelos Estados, medida já em andamento com iniciativa das Assembléias Legislativas, na forma do art. 60, III, da $\mathrm{CF}^{198}$.

Com efeito, o conceito de "normas gerais" é um tanto quanto impreciso, e, justamente por isso, é fonte de insegurança jurídica, de forma a facilitar o abuso de sua utilização por parte da União, e a conseqüente judicialização de contendas referentes à sua aplicação. E, nessa oportunidade, há de se convir com os autores que entendem ser indefinida sua constatação lógico-formal, tanto porque a lei por natureza já é dotada de generalidade.

Nesse sentido pondera Elival Silva Ramos ao concluir que o conceito de normas gerais e, correlatamente, também o de normas específicas, é do tipo que contém uma considerável zona de indeterminação, aclarável, apenas pelo aplicador da lei, no deslinde do caso concreto $^{199}$.

No capítulo das competências concorrentes o próprio filósofo Tércio Sampaio Ferraz $^{200}$ observa que o critério lógico-formal muitas vezes é insuficiente para distinguir com propriedade as normas gerais, daí sugerir que se recorra à interpretação sistemática conforme o interesse regrado para verificar se se trata de normas gerais. Registra, no entanto, que a competência concorrente admitida no Brasil é tipicamente não-cumulativa, pois há uma préordenação da extensão dos campos de atuação do poder central e do poder estadual, pois limita o primeiro à atuação no campo dos princípios e normas gerais.

Em que pese a dificuldade do tema, parece necessário alcançar alguns esclarecimentos para conferir maior lucidez às normas de condomínio legislativo próprias da competência concorrente, justamente para amparar o conceito de normas gerais.

\footnotetext{
${ }^{198}$ AMARAL, Antonio, (artigo) reportagem divulgada no jornal $O$ Estado de S. Paulo datada do dia $1^{\circ}$ de junho de 2009, p. A4, foi noticiada a tramitação de proposta de Emenda Constitucional para o fim de ampliar atribuição das Assembléias Legislativas, através da ampliação das competências concorrentes em detrimento das competências privativas da União Federal especialmente para as matérias referentes a trânsito e transporte, direito agrário, diretrizes e bases da educação, propaganda comercial, licitação e matéria processual. Esclarece a reportagem de Silvia Amorim que o texto já fora aprovado pelas Assembléias de MG, PB, ES e RR.

199 RAMOS, Elival Silva. Federação - competência legislativa (normas gerais de competência da União e competência supletiva dos Estados: a questão dos agrotóxicos). Revista de Direito Público, São Paulo, ano XIX, n. 77, jan./mar. 1986, p. 127.

${ }^{200}$ FERRAZ, Anna Cândida da Cunha. Conflito entre poderes: o poder congressual de sustar atos normativos do Poder Executivo. São Paulo: Revista dos Tribunais, 1994, p. 16-20.
} 
Sobre o tema, Diogo de Figueiredo Neto ressalta que há três graus de generalização normativa: um generalíssimo, onde se situam as normas-princípio; um geral, onde se situam as normas gerais e, por fim, um sub-geral, que é o das normas particularizantes. Já em relação às normas gerais, o autor aponta os seus caracteres genéricos, conforme previsto pela doutrina: $a$ ) estabeleçam princípios, diretrizes e regras jurídicas gerais; b) não entram em pormenores $e$ detalhes, não esgotando o assunto legislado; c) devem possuir abrangência nacional, aplicando-se igualmente a todas entidades federadas; d) devem ser regras uniformes para situações homogêneas; e) cabem em áreas de conflito (entre entidades federadas); f) referemse a questões fundamentais ${ }^{201}$.

Tomem-se, pois, essas características para delimitar o conceito de normas gerais. Vislumbra-se, daí, a conotação de uniformidade nacional, como típica característica para as normas gerais da União, também chamadas por alguns de normas nacionais, pois aplicáveis a toda Federação. Esse o intento do constituinte, cuja diretriz pragmática fora justamente impedir conflitos de conceitos fundantes e de políticas nacionais. No esteio desse raciocínio pondera Marcelo Araújo ${ }^{202}$ (grifei):

$\mathrm{Na}$ verdade, a possibilidade dos Estados-membros legislarem atendendo às suas peculiaridades deve respeitar um mínimo de uniformização legislativa que terá sua fronteira traçada por norma da União. Ou seja, se o constituinte relacionou determinadas matérias como integrantes de uma competência legislativa concorrente não cumulativa, é porque viu nelas essa necessidade de um mínimo de uniformização, sem que isso signifique centralização de acordo com a realidade concreta dos casos por eles vividos.

A dificuldade reside em encontrar o equilíbrio entre a uniformidade e a diversidade legislativa. Equilíbrio este que deverá ser buscado através do principio de subsidiariedade. Na verdade, ao prever a Constituição Federal de 1988, em seu art. 24, matérias que receberiam a atenção de variados entes federados, teve o constituinte em conta exatamente a percepção da necessidade de proporcionar a diversidade dos Estados-membros, equilibrando a diversidade com a unidade do Estado Federal.

(...)

Vê-se, assim, que no condomínio legislativo a União possui uma função de estabelecer, por meio de normas gerais, um núcleo mínimo que merece respeito quando do desenvolvimento das competências legislativas pelos Estados-membros, a fim de organizar as legislações que, emanadas de fontes diversas, tenham por objeto um mesmo assunto.

Integram as regras constitucionais de convivência as normas gerais que são editadas pela União, bem como a competência suplementar que é exercida pelos Estadosmembros. Na verdade, trata-se de encontrar um meio de fazer com que as atividades

\footnotetext{
${ }^{201}$ FIGUEIREDO NETO, 1988, p. 149-150.

${ }^{202}$ ARAÚJO, Marcelo Labanca C. de. O condomínio legislativo. Dissertação (Mestrado em Direito Constitucional) Universidade Federal de Pernambuco, Recife, 2001, p. 111-112.
} 
legislativas compartilhadas não entrem em choque. Foi com essa intenção que o Constituinte elaborou os parágrafos do art. 24 supra mencionados.

Enfim, diante de tais características denota-se os caracteres genéricos de integração das normas gerais para as instituições bases de uma política legislativa sobre determinado assunto, de forma a franquear margem de regramento próprio aos Estados-membros por meio de normas particularizantes, baseado numa correlação de integração e autonomia.

Justamente para a preservação da autonomia dos entes federados, consistente na possibilidade de se firmar diferenças para atender peculiaridades próprias, ter-se-á o equilíbrio perquirido pelo constituinte ao instituir as competências concorrentes. Mister, observar, portanto, que o pano de fundo em foco é justamente o respeito à margem de espaço próprio dos Estados-membros para que possam regulamentar interesses que lhe são peculiares, sob o amálgama próprio do federalismo, a preservação da diversidade na unidade.

E a realização prática desse princípio-mor do federalismo só ocorre mediante efetivo espaço político, institucional e legislativo dos Estados-membros. A propósito, Marcelo Araújo anota que para que seja respeitada a pluralidade política e a autonomia das entidades que integram a federação é necessário que haja espaço para o desenvolvimento dessa pluralidade. Ou seja, é necessário que exista um âmbito onde a diversidade irá atuar, produzindo aspectos políticos de organização dessemelhantes entre os Estados-membros ${ }^{203}$.

Lança então o exemplo referente ao direito penitenciário, matéria arrolada como competência concorrente no art. 24 , I, da $\mathrm{CF}$, tanto porque as realidades acerca da criminalidade são distintas entre os Estados - e, como tal, há significativa margem de adequação da lei estadual às questões envoltas ao cumprimento de penas e à recuperação do condenado, como o envolvimento da comunidade para reintegrar o condenado à sociedade, entre outras tantas peculiaridades próprias de cada Estado referentes à questão, até então abandonada pelo parlamentar estadual - pois só se tem notícia de regras federais que regem o assunto.

A mesma tônica se repete no direito urbanístico, em procedimentos em matéria processual, funcionamento e processo do juizado de pequenas causas, pois continentalmente destoante a geografia, as condições sociais e até o acesso à justiça nos diferentes rincões do

\footnotetext{
${ }^{203}$ ARAÚJO, 2001, p. 110.
} 
País. Por isso, as normas estaduais devem particularizar e atender essas peculiaridades para tornar mais eficiente e acessível tais direitos, até como forma de desenvolvimento nacional.

Expressivo número de autores defende a aplicação do princípio da subsidiariedade no plano de repartição de competências legislativas concorrentes, dada a semântica do art. 24 e parágrafos da Constituição da República, de forma a compartilhar o poder de legislar entre os Estados-membros e a União. Ou seja, é preciso conformar a repartição constitucional de competências legislativas concorrentes à luz do princípio da subsidiariedade como forma de proporcionar o equilíbrio entre as forças contrastantes no federalismo brasileiro.

Entenda-se quanto ao princípio da subsidiariedade a relação de supletividade e contenção ínsita a duas categorias que se inter-relacionam, como o Estado e a sociedade, o Direito Público e o Privado. Sua noção gravita, assim, em torno da idéia de limite à intervenção da entidade superior sobre a inferior, como respeito às atribuições próprias da última $^{204}$.

Quanto à aplicação do princípio da subsidiariedade no âmbito do federalismo vale descrever o raciocínio contido na Dissertação de Mestrado de Marcelo Araújo ${ }^{205}$ :

Inclusive, José Alfredo de Oliveira Baracho afirma que o principio de subsidiariedade, "inspira inteiramente o sistema federal. Representa a expressão mais clara e formal do principio federativo, por ser o conteúdo mais significativo para a sua elaboração".

Em razão disso, o principio de subsidiariedade pode ser inserido na temática da repartição de competências legislativas compartilhadas, levando-se em conta que ele privilegia o exercício de competências em grau mais próximo daqueles que sofrerão a sua incidência. Ou seja, privilegia a atuação legislativa do Estado-membro, em detrimento da legislação da União, que poderá atuar em caso de necessidade para a obtenção de maior eficiência e organicidade no que atina ao sistema legislativo da federação. É esse o sentido que deve ser extraído dos parágrafos do art. 24, ao estabelecer a competência de normas gerais da União e a competência suplementar dos Estados-membros, criando uma verdadeira subsidiariedade no plano das competências legislativas compartilhadas

(...)

A repartição concorrente, então, seria, em termos ideais, uma das formas de atenuar a centralização, eis que as matérias antes referentes aos governos locais que passaram a ser assumidas pelos governos centrais, teriam uma trajetória de volta intermediária, ou seja, estariam voltando aos governos locais não para o exercício exclusivo, mas sob a forma de compartilhamento com o governo central. (...)

\footnotetext{
${ }^{204}$ Sobre o tema, Cf. BARACHO, José Alfredo de Oliveira. O princípio da subsidiariedade: conceito e evolução. Revista de Direito Administrativo, n. 200, p. 21-54, abr./jun. 1995.

${ }^{205}$ ARAÚJO, 2001, p. 141-142, 146.
} 
Nesse passo, é preciso observar que quando se leva em consideração o principio de subsidiariedade no desenvolvimento das competências legislativas no Brasil, ele passa a ser um princípio jurídico de alocação das competências da União e dos Estados-membros, pois tentará criar campos de atuação do legislador federal ou estadual, com a finalidade de organizar e compatibilizar a legislação sobre uma mesma matéria. E se um dos entes (União ou Estados-membros) não respeitar esses campos de atuação, a produção normativa não será válida.

Portanto, a partir do momento em que a União deixar no condomínio legislativo um maior campos de legislação dos Estados-membros, estará ela atuando de acordo com o princípio de subsidiariedade. Ou seja, as normas gerais da União apenas devem ser editadas quando realmente indispensáveis para dar um mínimo de unidade às diversidades legislativas. E assim sendo, a atuação da comunidade maior, no caso a União, seria pautada em razão da indispensabilidade de uma norma geral sua. E mais, essa norma geral, uma vez editada, teria uma razão a mais para não adentrar nas competências dos Estados-membros, pois o pano de fundo que impera no princípio de subsidiariedade é exatamente a maior descentralização, levando em conta que os entes devem fazer o que puderem com seus próprios esforços.

Assim, o princípio de subsidiariedade funcionará como um dos elementos de identificação da legitimidade da atuação da União no campo das normas gerais, impedindo que a União, no exercício dessa competência, utilize-se da margem de imprecisão do conceito de normas gerais para descer a detalhes.

O autor enriquece ainda discussão quando cita trabalho de Silvia Faber Torres ${ }^{206}$ referente à aplicação do princípio da subsidiariedade no âmbito das nações européias, questão então apreciada pelo Conselho Europeu em Edimburg, em dezembro de 1992, que definiu que o princípio da subsidiariedade visa a respeitar a identidade dos Estados-membros, e, portanto, assegurar que o processo decisório seja realizado no plano mais baixo - de forma que toda ação da Comunidade Européia deveria ser previamente justificada. Assinala, assim, as razões de sua atuação, tidas como pertinentes quando: a) seus objetivos não poderiam ser atingidos de maneira suficiente pelos Estados-membros; b) apresentam aspectos que transcendam ao interesse de um ou mais Estados-membros (aspectos transnacionais).

$\mathrm{O}$ incidente repete-se no contexto nacional, de forma que o balizamento das normas gerais da União Federal deverá ser feito à luz dos critérios lançados por Diogo de Figueiredo Neto em linhas acima, condizente com a realidade política delineada pelo interesse em foco.

Segundo esse entendimento, o princípio da subsidiariedade é lançado como princípio fundamental do federalismo, por ter como essência filosófica fortalecer a autonomia de uma entidade que interage com um sistema; assim, sua tônica tem perfeita aplicabilidade ao federalismo, cuja gênese mescla-se no binômio: unidade na diversidade. Logo, a aplicação do princípio das subsidiaridade à competência concorrente é viável, justamente porque essa

\footnotetext{
${ }^{206}$ TORRES apud ARAÚJO, 2001.
} 
competência trabalha com dois níveis de interação normativa - a federal e a estadual - de sorte que, presentes as hipóteses destacadas nos parágrafos acima, se sustenta a competência federal; ausente tais hipóteses, predica a subsidiariedade que deverá ser guarnecida à autonomia legislativa para os Estados-membros regularem seus interesses e peculiaridades no campo da competência concorrente.

Deveras, Baracho ${ }^{207}$ aponta que a subsidiariedade não é apenas um simples princípio de repartição de competências entre órgãos e coletividades estatais. Ela fixa o próprio princípio de competências, daí decorre que a subsidiariedade possa ser um princípio de Direito Constitucional, aparece na organização administrativa do Estado, de sorte que o debate não é apenas o da descentralização, mas da desconcentração.

Conforme considerações já lançadas ${ }^{208}$, consignamos que enquanto normas gerais no âmbito da competência concorrente, as normas provindas da União Federal gozam status de superioridade hierárquica, de forma a prevalecer no caso de antinomias - desde que se trate de normas gerais (no limite de seu alcance ${ }^{209}$ ) e assim, não sufoquem a autonomia referente às particularidades próprias dos demais entes federados, justamente porque a partir daí não serão normas gerais, mas particulares.

Nesse sentido entendeu o STF na ADI n. 3.669/DF ao julgar improcedente a ação e sufragar legitimidade da legislação estadual de ensino que conferiu oportunidade de ensino do idioma espanhol. Entendeu o STF que não houve afronta às normas gerais da União Federal, conforme ementa seguinte:

EMENTA: AÇÃO DIRETA DE INCONSTITUCIONALIDADE. LEI DISTRITAL N. 3.694, DE 8 DE NOVEMBRO DE 2005, QUE REGULAMENTA O $\S 1^{\circ}$ DO ART. 235 DA LEI ORGÂNICA DO DISTRITO FEDERAL QUANTO À OFERTA DE ENSINO DA LÍNGUA ESPANHOLA AOS ALUNOS DA REDE PÚBLICA DO DISTRITO FEDERAL. AUSÊNCIA DE AFRONTA À CONSTITUIÇÃO DA REPÚBLICA. 1. Competência concorrente entre a União, que define as normas gerais e os entes estaduais e Distrito Federal, que fixam as especificidades, os modos e meios de cumprir o quanto estabelecido no art. 24, inc. IX, da Constituição da República, ou seja, para legislar sobre educação. 2. O art. 22, inc. XXIV, da Constituição da República enfatiza a competência privativa do legislador nacional

\footnotetext{
${ }^{207}$ BARACHO, 1995, p. 54.

${ }^{208}$ Capítulo da Competência Concorrente.

${ }^{209}$ O STF decidiu no âmbito da ADI MC n 2.338- SC, que o Estado-membro tem competência residual para legislar sobre licitação, como expressão de sua competência residual - exemplo baseado no raciocínio a contrariu sensu, pois o STF adotou entendimento restritivo para deliberar sobre o controle de constitucionalidade abstrato no âmbito da competência vertical, especificamente relativo ao condomínio legislativo. Entende o STF que a questão não há de ser aferida no controle abstrato, justamente porque demanda análise de legalidade (ADI 2344).
} 
para definir as diretrizes e bases da educação nacional, deixando as singularidades no âmbito de competência dos Estados e do Distrito Federal. 3. Ação direta de inconstitucionalidade julgada improcedente.

Uma vez particularizadas as normas próprias da União Federal no âmbito da competência concorrente, só valerão (e quando valerão) para a própria União Federal, especialmente para questões tributárias, financeiras, administrativas (sua própria Defensoria Pública e seus próprios servidores) - esse foi o entendimento do STF no âmbito da ADIn-MC no 927-3/RS ${ }^{210}$, justamente na análise do art. 17, II, $b$, da Lei Federal n. 8.666/93.

Deveras, outro não poderia ser o entendimento do Tribunal guardião de nossa Carta Política e, por conseqüência, de nosso pacto federativo, pois se a União positivar legislação que enfatize detalhes sobre um instituto jurídico, ou melhor, que o desdobre a minúcias, essas particularidades só poderão valer para si, sob pena de se fazer tabula rasa do conceito expresso no art. $24, \S 1^{\circ}$, que confere à União Federal a prerrogativa de editar normas gerais e não de normas particularizantes.

Note-se, pois, que além do caráter distintamente genérico, no dizer de Raul Horta, normas moldura, as normas gerais da União Federal têm sinal distinto das demais competências, justamente em razão da hierarquia que as normas gerais apresentam e firmam ao chamado condomínio legislativo. É o que se pode entender da vontade do constituinte expressa no último parágrafo do art. 24 da Constituição da República, de sorte a não pairar dúvidas que caberá à União editar normas gerais justamente para congregar unidade no regramento de determinadas matérias sobre todo o País e nesse contexto ser considerada norma de maior envergadura que as demais. Eis a semântica que se apreende da competência concorrente relativa às normas gerais, e enquanto tais.

André Tavares realizou expressiva pesquisa na jurisprudência do STF para abalizar o conceito de norma geral em sede de conflito com norma estadual. Concluiu de forma pragmática que norma geral é aquela que admite ou veda determinada conduta no sentido de que, se determinada lei federal admitir certa prática, não caberá à lei estadual estabelecer o

${ }^{210}$ EMENTA: CONSTITUCIONAL. LICITAÇÃO. CONTRATAÇÃO ADMINISTRATIVA. Lei n. 8.666, de 21.06.93. I. - Interpretação conforme dada ao art. 17, I, "b" (doação de bem imóvel) e art. 17, II, "b" (permuta de bem movel), para esclarecer que a vedação tem aplicação no âmbito da União Federal, apenas. Idêntico entendimento em relação ao art. 17, I, "c" e par. 1. do art. 17. Vencido o Relator, nesta parte. II. - Cautelar deferida, em parte. 
contrário; se determinada lei federal proibir certa prática, a lei estadual não poderá permiti$\mathrm{la}^{211}$. Ratifica-se essa assertiva, desde que não se trate de norma que desdobre a minúcias a regulação do instituto.

Esse foi o entendimento do STF quanto à questão da vedação ao amianto crisotila, conforme se extrai do julgamento da ADIn $\mathrm{n}^{\circ}$ 2.656-9/SP e do voto do Ministro relator Maurício Correa:

No caso é evidente que a lei paulista contraria a lei federal, pois esta última, longe de vedar o emprego do amianto "crisotila", regula a forma adequada para sua legítima extração, industrialização, utilização, e comercialização. A situação implica, desde logo, a ilegalidade dos dispositivos em análise. Para fins de controle concentrado, no entanto, a questão de relevo é que a legislação local cuida de normas gerais sobre produção e consumo de amianto, o que afronta as regras de repartição de competência concorrente previstas no art. 24 da Constituição Federal. (DJ, 01 ago. 2003)

No mesmo sentido foi o julgamento da lei paranaense n. 14.861/05 sobre substâncias geneticamente modificadas com preceitos contraditórios à Lei Federal n. 11.105/05, eis que o STF julgou procedente a ADI n 3.645 , com a seguinte ementa:

AÇÃO DIRETA DE INCONSTITUCIONALIDADE. LEI 14.861/05, DO ESTADO DO PARANÁ. INFORMAÇÃO QUANTO À PRESENÇA DE ORGANISMOS GENETICAMENTE MODIFICADOS EM ALIMENTOS E INGREDIENTES ALIMENTARES DESTINADOS AO CONSUMO HUMANO E ANIMAL. LEI FEDERAL 11.105/05 E DECRETOS 4.680/03 E 5.591/05. COMPETÊNCIA LEGISLATIVA CONCORRENTE PARA DISPOR SOBRE PRODUÇÃO, CONSUMO E PROTEÇÃO E DEFESA DA SAÚDE. ART. 24, V E XII, DA CONSTITUIÇÃO FEDERAL. ESTABELECIMENTO DE NORMAS GERAIS PELA UNIẪO E COMPETÊNCIA SUPLEMENTAR DOS ESTADOS. 1. Preliminar de ofensa reflexa afastada, uma vez que a despeito da constatação, pelo Tribunal, da existência de normas federais tratando da mesma temática, está o exame na ação adstrito à eventual e direta ofensa, pela lei atacada, das regras constitucionais de repartição da competência legislativa. Precedente: ADI 2.535-MC, rel. Min. Sepúlveda Pertence, DJ 21.11.03. 2. Seja dispondo sobre consumo (CF, art. 24, V), seja sobre proteção e defesa da saúde (CF, art. 24, XII), busca o Diploma estadual impugnado inaugurar regulamentação paralela e explicitamente contraposta à legislação federal vigente. 3. Ocorrência de substituição - e não suplementação - das regras que cuidam das exigências, procedimentos e penalidades relativos à rotulagem informativa de produtos transgênicos por norma estadual que dispôs sobre o tema de maneira igualmente abrangente. Extrapolação, pelo legislador estadual, da autorização constitucional voltada para o preenchimento de lacunas acaso verificadas na legislação federal. Precedente: ADI 3.035, rel. Min. Gilmar Mendes, DJ 14.10.05. 4. Declaração de inconstitucionalidade consequencial ou por arrastamento de decreto regulamentar superveniente em razão da relação de dependência entre sua validade e a legitimidade constitucional da lei objeto da ação. Precedentes: ADI 437-QO, rel.

\footnotetext{
${ }^{211}$ TAVARES, 2008, p. 178.
} 
Min. Celso de Mello, DJ 19.02.93 e ADI 173-MC, rel. Min. Moreira Alves, DJ 27.04.90. 5. Ação direta cujo pedido formulado se julga procedente.

Outra característica relevante, conforme já delineado acima, para aferir as normas gerais é justamente o efeito ou repercussão da legislação, consoante aborda Tércio Sampaio Ferraz Júnior ${ }^{212}$ ao explicitar que o critério lógico-formal muitas vezes é insuficiente para distinguir com propriedade as normas gerais, daí sugerir que se recorra à interpretação sistemática conforme o interesse regrado para se denotar se se trata de normas gerais:

(...) A lógica, porém, ajuda mas não resolve inteiramente a questão interpretativa. A expressão constitucional - normas gerais - exige também uma hermenêutica teleológica.

Sob o mencionado aspecto lógico sempre será possível dizer que, por exemplo, quanto ao conteúdo, normas gerais prescrevem princípios, diretrizes sistemáticas, temas que se referem a uma espécie inteira e não a alguns aspectos, mas isto é insuficiente para reconhecer quando estamos diante de uma norma geral ou de uma particular. Sempre restarão dúvidas, no caso concreto, para aplicar o critério estritamente lógico-formal. Deste modo, para o intérprete, a necessidade de se analisar o conteúdo num contexto finalístico se impõe. Assim, do ângulo teleológico, a distinção há de se reportar ao interesse prevalecente na organização federativa.

Justamente nessa ótica - teleológica, baseada no escopo normativo, em cotejo com o objeto jurídico então tutelado - decidiu o STF pela inconstitucionalidade de norma estadual que determine efeitos para outro ente federado no âmbito da ADIn n ${ }^{\circ}$ 280-5/MT ${ }^{213}$ que declarou a inconstitucionalidade de preceito da Constituição do Estado que não permitia a saída do Estado de madeira em toras, porquanto o preceito repercute diretamente sobre o comércio interestadual (art. 22, VIII, CF); o mesmo ocorreu no âmbito da ADIn $n^{\circ} 2.866$ 9/RN que julgou inconstitucional as normas contidas na Lei n. 8.299/03 do Rio Grande do Norte que restringiam o beneficiamento de sal marinho fora do Estado, cuja decisão ${ }^{214}$ reconheceu invasão da seara do comércio inter-estadual, privativa da União.

\footnotetext{
${ }^{212}$ FERRAZ JUNIOR, 1994, p. 16-20.

${ }^{213}$ EMENTA: - AÇÃO DIRETA DE INCONSTITUCIONALIDADE. ARTIGO 346 DA CONSTITUIÇÃO DO ESTADO DE MATO GROSSO. Inconstitucionalidade da frase "sendo vedada a saída do Estado de madeiras em toras". Competência da União para legislar sobre comercio interestadual e transporte (artigo 22 - VIII e XI da Constituição Federal). Precedentes do S.T.F.

${ }^{214}$ Consignaram os Ministros que a restrição ao comércio do sal marinho representa usurpação da competência privativa da União relativa ao comércio interestadual (art. 22, VIII, da CF) - justamente em face legislação estadual projetar efeitos diretos para outra entidade federal com a menção expressa nesse sentido, atribuição institucional alheia à sua funcionalidade.
} 
A projeção de efeitos da legislação estadual para fora de sua circunscrição é tida como efeitos próprios do comércio interestadual, privativo da União Federal, ex vi o art. 22, VIII, da Constituição Federal. Tal entendimento fora ainda catalogado na ADIn $n^{\circ}$ 2.832/PR, cuja querela debatia os efeitos de informação em rotulagens de produtos de café lastreado em lei estadual. O STF admitiu a racionalidade da legislação com base no feixe de competências concorrente de proteção ao consumidor, mas restringiu o preceito legal que estende os seus efeitos para outras unidades da federação.

\title{
3.7 Notas Sobre as Competências Legislativas Indiretas
}

Como já sustentado, a execução de tais tarefas administrativas pelos entes federados dá ensejo à competência legislativa indireta e concorrente para explicitação dos necessários comandos legislativos, em obséquio ao princípio da estrita legalidade, consoante leciona Anna Cândida Ferraz ${ }^{215}$ :

\begin{abstract}
As atividades a serem exercidas no campo material das competências 'comuns' somente poderão ser executadas, na generalidade dos casos, fundamentadas em regulamentação normativa precedente, oriunda de mais de um nível normativo de poder. Nesta hipótese, ocorrerá a chamada repartição vertical de competências, o que significa dizer que a atividade poderá ser exercida pelas diferentes esferas políticas, porém estará sujeita à disciplina legislativa hierarquizada e a regras gerais impostas pelo poder central.
\end{abstract}

Como o constituinte estipulou a competência administrativa concorrente, atribuindo a todos os entes federados o ônus e consequente responsabilidade de zelar por assuntos de acentuado interesse público, conforme se infere dos doze incisos do artigo 23 da CF, resta imperativo que comandos legais sejam traçados para conferir operacionalidade à competência administrativa concorrente, sob pena de cada ente deixar ao outro a tarefa de executar a tarefa administrativa.

Assim, merece ênfase a idéia de responsabilidade solidária entre os entes federados na prestação de tais serviços, em sintonia com o atributo de cooperação no seu regime administrativo, a teor de leis complementares federais de eficácia nacional, tendo em vista o equilíbrio de desenvolvimento e o bem-estar nacional, consoante dispõe o artigo 23 em seu parágrafo único.

\footnotetext{
${ }^{215}$ FERRAZ, 1989b, p. 65.
} 
Logo, caberá ao ente central ditar o regime de execução das áreas de competência comum. Enquanto ausente tal normativa, cada ente federativo é autônomo para expressar-se ao seu alvedrio e conveniência, mas sempre visando o bem estar nacional, objetivo maior de nossa República Federal (art. $3^{\circ}$, II, da CF).

Dada a profusão de normas administrativas advindas dessa seara normativa - ora nominada competência legislativa indireta ou decorrente - e a possibilidade de conflitos legislativos, tratar-se-á sobre uma dessas questões referentes à proteção do meio ambiente e à preservação de florestas, da fauna e da flora (art. 23, VI e VII, da CF) para melhor ilustrar a repercussão fática normativa para a solução dos conflitos.

$\mathrm{O}$ raciocínio jurídico será, portanto, delineado à luz de um caso concreto relativo às questões ambientais, dada a sua importância e reiterada presença na vida quotidiana. Vale, pois, traçar algumas notas sobre o papel dos entes federados na proteção e fiscalização do meio-ambiente.

Como se constata, cuida-se de competência concorrente tanto a competência legislativa (art. 24, VI, VII e VIII) como a atribuição material dos entes federados de proteger e fiscalizar o meio-ambiente. Contudo, a atribuição de cada ente federado no cumprimento desse mister é escalonada pela legislação, a teor das diretrizes constitucionais.

A atuação dos entes federados é, pois, ordenada, a teor da política nacional do meio ambiente instituída pela Lei Federal n. 6.938/81 (então recepcionada pela Constituição de 1988) e da legislação que a modificou nas três últimas décadas, de forma a otimizar a atuação dos entes federados para que cada ente político desempenhe função própria e peculiar às suas atribuições institucionais, como se nota dos arts. $4^{\circ}$ a $6^{\circ}$ da Lei n. $6.938 / 81^{216}$.

\footnotetext{
${ }^{216}$ Art $4^{\circ}$ - A Política Nacional do Meio Ambiente visará:

I - à compatibilização do desenvolvimento econômico-social com a preservação da qualidade do meio ambiente e do equilíbrio ecológico;

II - à definição de áreas prioritárias de ação governamental relativa à qualidade e ao equilíbrio ecológico, atendendo aos interesses da União, dos Estados, do Distrito Federal, dos Territórios e dos Municípios;

III - ao estabelecimento de critérios e padrões de qualidade ambiental e de normas relativas ao uso e manejo de recursos ambientais;

$I V$ - ao desenvolvimento de pesquisas e de tecnologias nacionais orientadas para o uso racional de recursos ambientais;

$V$ - à difusão de tecnologias de manejo do meio ambiente, à divulgação de dados e informações ambientais e à formação de uma consciência pública sobre a necessidade de preservação da qualidade ambiental e do equilíbrio ecológico;

$V I$ - à preservação e restauração dos recursos ambientais com vistas à sua utilização racional $e$ disponibilidade permanente, concorrendo para a manutenção do equilíbrio ecológico propício à vida;
} 
Em termos práticos, cabe ao CONAMA estabelecer a participação de cada ente federado na proteção e fiscalização do meio ambiente, a teor da interpretação dos arts. 10 a 12 da Lei n. 6.938/81:

Art. 10 - A construção, instalação, ampliação e funcionamento de estabelecimentos e atividades utilizadoras de recursos ambientais, considerados efetiva e potencialmente poluidores, bem como os capazes, sob qualquer forma, de causar degradação ambiental, dependerão de prévio licenciamento de órgão estadual competente, integrante do Sistema Nacional do Meio Ambiente - SISNAMA, $e$ do Instituto Brasileiro do Meio Ambiente e Recursos Naturais Renováveis IBAMA, em caráter supletivo, sem prejuízo de outras licenças exigíveis.

VII - à imposição, ao poluidor e ao predador, da obrigação de recuperar elou indenizar os danos causados $e$, ao usuário, da contribuição pela utilização de recursos ambientais com fins econômicos.

Art $5^{\circ}$ - As diretrizes da Política Nacional do Meio Ambiente serão formuladas em normas e planos, destinados a orientar a ação dos Governos da União, dos Estados, do Distrito Federal, dos Territórios e dos Municípios no que se relaciona com a preservação da qualidade ambiental e manutenção do equilíbrio ecológico, observados os princípios estabelecidos no art. $2^{\circ}$ desta Lei.

Parágrafo único - As atividades empresariais públicas ou privadas serão exercidas em consonância com as diretrizes da Política Nacional do Meio Ambiente.

\section{DO SISTEMA NACIONAL DO MEIO AMBIENTE}

Art $6^{\circ}$ - Os órgãos e entidades da União, dos Estados, do Distrito Federal, dos Territórios e dos Municípios, bem como as fundações instituídas pelo Poder Público, responsáveis pela proteção e melhoria da qualidade ambiental, constituirão o Sistema Nacional do Meio Ambiente - SISNAMA, assim estruturado:

I - órgão superior: o Conselho de Governo, com a função de assessorar o Presidente da República na formulação da política nacional e nas diretrizes governamentais para o meio ambiente e os recursos ambientais;

II - órgão consultivo e deliberativo: o Conselho Nacional do Meio Ambiente (CONAMA), com a finalidade de assessorar, estudar e propor ao Conselho de Governo, diretrizes de políticas governamentais para o meio ambiente e os recursos naturais e deliberar, no âmbito de sua competência, sobre normas e padrões compativeis com o meio ambiente ecologicamente equilibrado e essencial à sadia qualidade de vida;

III - órgão central: a Secretaria do Meio Ambiente da Presidência da República, com a finalidade de planejar, coordenar, supervisionar e controlar, como órgão federal, a política nacional e as diretrizes governamentais fixadas para o meio ambiente;

IV - órgão executor: o Instituto Brasileiro do Meio Ambiente e dos Recursos Naturais Renováveis, com a finalidade de executar e fazer executar, como órgão federal, a política e diretrizes governamentais fixadas para o meio ambiente;

$V$ - Órgãos Seccionais: os órgãos ou entidades estaduais responsáveis pela execução de programas, projetos e pelo controle e fiscalização de atividades capazes de provocar a degradação ambiental;

VI - Órgãos Locais: os órgãos ou entidades municipais, responsáveis pelo controle e fiscalização dessas atividades, nas suas respectivas jurisdições;

$\S 1^{\circ}$ Os Estados, na esfera de suas competências e nas áreas de sua jurisdição, elaboração normas supletivas e complementares e padrões relacionados com o meio ambiente, observados os que forem estabelecidos pelo CONAMA.

$\S 2^{\circ} \mathrm{O}$ s Municípios, observadas as normas e os padrões federais e estaduais, também poderão elaborar as normas mencionadas no parágrafo anterior.

$\S 3^{\circ}$ Os órgãos central, setoriais, seccionais e locais mencionados neste artigo deverão fornecer os resultados das análises efetuadas e sua fundamentação, quando solicitados por pessoa legitimamente interessada.

$\S 4^{\circ}$ De acordo com a legislação em vigor, é o Poder Executivo autorizado a criar uma Fundação de apoio técnico científico às atividades do IBAMA. 
$\S 1^{o}$ - Os pedidos de licenciamento, sua renovação e a respectiva concessão serão publicados no jornal oficial do Estado, bem como em um periódico regional ou local de grande circulação.

$\S 2^{\circ}$ Nos casos e prazos previstos em resolução do CONAMA, o licenciamento de que trata este artigo dependerá de homologação do IBAMA.

$\S 3^{\circ} O$ órgão estadual do meio ambiente e o IBAMA, esta em caráter supletivo, poderão, se necessário e sem prejuízo das penalidades pecuniárias cabíveis, determinar a redução das atividades geradoras de poluição, para manter as emissões gasosas, os efluentes líquidos e os resíduos sólidos dentro das condições e limites estipulados no licenciamento concedido.

$\S 4^{\circ}$ Compete ao Instituto Brasileiro do Meio Ambiente e Recursos Naturais Renováveis - IBAMA o licenciamento previsto no caput deste artigo, no caso de atividades e obras com significativo impacto ambiental, de âmbito nacional ou regional.

Art. 11. Compete ao IBAMA propor ao CONAMA normas e padrões para implantação, acompanhamento e fiscalização do licenciamento previsto no artigo anterior, além das que forem oriundas do próprio CONAMA.

$\S 1^{\circ}$ A fiscalização e o controle da aplicação de critérios, normas e padrões de qualidade ambiental serão exercidos pelo IBAMA, em caráter supletivo da atuação do órgão estadual e municipal competentes.

$\S 2^{\circ}$ - Inclui-se na competência da fiscalização e controle a análise de projetos de entidades, públicas ou privadas, objetivando a preservação ou a recuperação de recursos ambientais, afetados por processos de exploração predatórios ou poluidores.

A Resolução CONAMA n. $237^{217}$ implementa a atuação dos entes federados em princípio única para cada atividade, nos termos do art. $7^{\circ}$, que "os empreendimentos e

217 Art. $2^{\circ}$ - A localização, construção, instalação, ampliação, modificação e operação de empreendimentos e atividades utilizadoras de recursos ambientais consideradas efetiva ou potencialmente poluidoras, bem como os empreendimentos capazes, sob qualquer forma, de causar degradação ambiental, dependerão de prévio licenciamento do órgão ambiental competente, sem prejuízo de outras licenças legalmente exigíveis.

$\S 1^{\circ}$ - Estão sujeitos ao licenciamento ambiental os empreendimentos e as atividades relacionadas no Anexo 1, parte integrante desta Resolução.

$\S 2^{\circ}$ - Caberá ao órgão ambiental competente definir os critérios de exigibilidade, o detalhamento e a complementação do Anexo 1, levando em consideração as especificidades, os riscos ambientais, o porte e outras características do empreendimento ou atividade.

Art. $3^{\circ}$ - A licença ambiental para empreendimentos e atividades consideradas efetiva ou potencialmente causadoras de significativa degradação do meio dependerá de prévio estudo de impacto ambiental e respectivo relatório de impacto sobre o meio ambiente (EIA/RIMA), ao qual dar-se-á publicidade, garantida a realização de audiências públicas, quando couber, de acordo com a regulamentação.

Parágrafo único. O órgão ambiental competente, verificando que a atividade ou empreendimento não é potencialmente causador de significativa degradação do meio ambiente, definirá os estudos ambientais pertinentes ao respectivo processo de licenciamento.

Art. $4^{\circ}$ - Compete ao Instituto Brasileiro do Meio Ambiente e dos Recursos Naturais Renováveis - IBAMA, órgão executor do SISNAMA, o licenciamento ambiental, a que se refere o artigo 10 da Lei $\mathrm{n}^{\circ}$ 6.938, de 31 de agosto de 1981, de empreendimentos e atividades com significativo impacto ambiental de âmbito nacional ou regional, a saber:

I - localizadas ou desenvolvidas conjuntamente no Brasil e em país limítrofe; no mar territorial; na plataforma continental; na zona econômica exclusiva; em terras indígenas ou em unidades de conservação do domínio da União.

II - localizadas ou desenvolvidas em dois ou mais Estados;

III - cujos impactos ambientais diretos ultrapassem os limites territoriais do País ou de um ou mais Estados; 
atividades serão licenciados em um único nível de competência, conforme está estabelecido nos artigos anteriores".

Assim, a atuação de cada ente federado para fiscalização do meio ambiente dependerá da atividade objeto do licenciamento e dos respectivos efeitos poluidores - de forma que a atuação do IBAMA $^{218}$ só ocorrerá quando presente potencial dano ambiental de caráter nacional ou regional.

IV - destinados a pesquisar, lavrar, produzir, beneficiar, transportar, armazenar e dispor material radioativo, em qualquer estágio, ou que utilizem energia nuclear em qualquer de suas formas e aplicações, mediante parecer da Comissão Nacional de Energia Nuclear - CNEN;

$\mathrm{V}$ - bases ou empreendimentos militares, quando couber, observada a legislação específica.

$\S 1^{\circ}$ - O IBAMA fará o licenciamento de que trata este artigo após considerar o exame técnico procedido pelos órgãos ambientais dos Estados e Municípios em que se localizar a atividade ou empreendimento, bem como, quando couber, o parecer dos demais órgãos competentes da União, dos Estados, do Distrito Federal e dos Municípios, envolvidos no procedimento de licenciamento.

$\S 2^{\circ}$ - O IBAMA, ressalvada sua competência supletiva, poderá delegar aos Estados o licenciamento de atividade com significativo impacto ambiental de âmbito regional, uniformizando, quando possível, as exigências.

Art. $5^{\circ}$ - Compete ao órgão ambiental estadual ou do Distrito Federal o licenciamento ambiental dos empreendimentos e atividades:

I - localizados ou desenvolvidos em mais de um Município ou em unidades de conservação de domínio estadual ou do Distrito Federal;

II - localizados ou desenvolvidos nas florestas e demais formas de vegetação natural de preservação permanente relacionadas no artigo $2^{\circ}$ da Lei $\mathrm{n}^{\circ} 4.771$, de 15 de setembro de 1965 , e em todas as que assim forem consideradas por normas federais, estaduais ou municipais;

III - cujos impactos ambientais diretos ultrapassem os limites territoriais de um ou mais Municípios;

IV - delegados pela União aos Estados ou ao Distrito Federal, por instrumento legal ou convênio.

Parágrafo único. O órgão ambiental estadual ou do Distrito Federal fará o licenciamento de que trata este artigo após considerar o exame técnico procedido pelos órgãos ambientais dos Municípios em que se localizar a atividade ou empreendimento, bem como, quando couber, o parecer dos demais órgãos competentes da União, dos Estados, do Distrito Federal e dos Municípios, envolvidos no procedimento de licenciamento.

Art. $6^{\circ}$ - Compete ao órgão ambiental municipal, ouvidos os órgãos competentes da União, dos Estados e do Distrito Federal, quando couber, o licenciamento ambiental de empreendimentos e atividades de impacto ambiental local e daquelas que lhe forem delegadas pelo Estado por instrumento legal ou convênio.

Art. $7^{\circ}$ - Os empreendimentos e atividades serão licenciados em um único nível de competência, conforme estabelecido nos artigos anteriores.

${ }^{218}$ Recentemente, o Ministério do Meio Ambiente, na qualidade de órgão central do SISNAMA (art. $6^{\circ}$, III, da Lei 6938/1981), decidiu conflito positivo de atribuições entre o IBAMA e a FATMA/SC, argumentando que o fato de a atividade licenciada atingir ou se localizar em bem da União não caracteriza a competência da autarquia federal para efetuar o licenciamento ambiental, pois este se dá em razão da abrangência do impacto ao meio ambiente, e não em virtude da titularidade do bem atingido (Despacho 2176/2004 - PROGE/GABIN, Parecer MMA 312/2008). Já no Parecer no 312/CONJUR/MMA/2004, lavrado pelo Consultor Jurídico do Ministério do Meio Ambiente, "não cabe aos Municípios e Estados pedir autorização à União para exercerem o poder de polícia administrativa, para organizarem seus serviços administrativo-ambientais ou para utilizarem os instrumentos da política nacional do meio ambiente, entre os quais se inclui o licenciamento ambiental". No documento, lê-se: "o licenciamento ambiental tem por fundamento compatibilizar a proteção do meio ambiente com o desenvolvimento econômico sustentável, tendo sua análise focada nos impactos ambientais da atividade ou empreendimento, não na titularidade dos bens afetados". Nele se assentou, outrossim: "Portanto, não basta que a atividade licenciada atinja ou se localize em bem da União para que fique caracterizada a competência do IBAMA para efetuar o licenciamento ambiental. O licenciamento ambiental dá-se em razão da abrangência do impacto ao meio ambiente e não em virtude da titularidade do bem atingido". 
Tanto é assim que o $§ 1^{\circ}$, do art. 11, da Lei n. 6.938/81, estabelece que "a fiscalização e o controle da aplicação de critérios, normas e padrões de qualidade ambiental serão exercidos pelo IBAMA, em caráter supletivo ${ }^{219}$ da atuação do órgão estadual e municipal competentes”. De teor similar é a norma do art. $10, \S 3^{\circ}$, do mesmo diploma legal.

Paulo Affonso Leme Machado, explicita que "a atuação supletiva do IBAMA, inobstante a lei não indicar os seus parâmetros, deverá ocorrer, principalmente, em duas situações: se o órgão estadual ambiental for inepto ou se o órgão permanecer inerte ou omisso" 220 . Essa assertiva encontra eco no princípio constitucional da conformidade funcional entre as atribuições institucionais da Federação, na lição de Paulo de Bessa Antunes, nos seguintes termos:

O Instituto Brasileiro do Meio Ambiente e dos Recursos Naturais Renováveis IBAMA exerce funções de caráter supletivo na atividade de licenciamento ambiental e na conseqüente fiscalização do efetivo cumprimento dos termos nos quais foi concedida a licença, isto porque o licenciamento é fundamentalmente desempenhado pelos órgãos estaduais integrantes do SISNAMA - Sistema Nacional do Meio Ambiente. Por atividade supletiva não se deve entender uma atividade exercida em substituição daquela que deva ser desempenhada pelo órgão estadual de controle ambiental, salvo na hipótese em que o órgão regional não exista. A atividade supletiva limita-se a atender aspectos secundários do processo de licenciamento. Não pode, contudo, o órgão federal, 'discordar' da licença concedida pelo órgão estadual e, na vigência desta, embargar obras, etc. Isto somente pode ocorrer, em tese, se o órgão federal demonstrar que a licença estadual está eivada de vício. A observância deste parâmetro de atribuição administrativa é fundamental para que o SISNAMA possa, de fato, existir. Se se admite que os órgãos públicos de diferentes esferas federativas possam, a seu talante, embargar, paralisar e contestar atividades que se encontram autorizadas regularmente pelo demais integrantes do SISNAMA, no uso normal e legal de suas atribuições, o sistema se torna completamente inviável. Aliás, a própria criação do SISNAMA tem por finalidade última a organização de atribuições diferenciadas e a descentralização administrativa de forma cooperativa e harmônica ${ }^{221}$.

A observação é de expressiva importância prática e dotada de fundada segurança jurídica para a sociedade, que já não sabe a quem prestar contas e nem se licenças administrativas concedidas por um ente valerão perante outros.

${ }^{219}$ O Regulamento Interno da Fiscalização do IBAMA, aprovado pela portaria IBAMA n. 53: "(...) Art. $7^{o}$ As ações fiscalizatórias terão as seguintes classificações: (...) V - Supletiva: quando em razão da inércia do Órgão Ambiental do Estado ou Município; VI - Emergência: para coibição de infrações de alto impacto ambiental; VII - De Ofício: por iniciativa própria".

${ }^{220}$ MACHADO, Paulo Affonso Leme. Direito Ambiental Brasileiro. 11 ed. São Paulo: Malheiros, 2003, p. 262.

${ }^{221}$ ANTUNES, Paulo de Bessa. Direito Ambiental. 6 ed. Rio de Janeiro: Lúmen Júris, 2002, p. 133. 
Uma das situações reveladoras desta necessidade de coordenação de esforços é o elevado número de Ações Civis Públicas por danos ambientais em que há duplicação de demandas por conta de ajuizamento simultâneo pelos Ministérios Públicos Estadual e Federal ou intervenção da autarquia federal IBAMA ou a desconsideração de atos de um destes órgãos por outros, tornando inócuos os termos de ajuste de conduta realizados e licenças ambientais expedidas.

Assim, no caso de eventual discordância do IBAMA - que tem o poder geral de polícia ambiental - com a licença ambiental concedida por órgão municipal/estadual, deverá o próprio IBAMA ajuizar ação judicial para tanto, já que a função de controle de legalidade externa à Administração Pública é função eminentemente jurisdicional (a chamada judicial review).

E, mutatis mutandis, já decidiu o STJ que "as penalidades da Lei n. 6.938/81 incidem sem prejuízo de outras previstas na legislação federal, estadual ou municipal (art. 14, caput) e somente podem ser aplicadas pelo órgão federal de proteção ao meio ambiente quando omissa a autoridade estadual ou municipal (art. 14, $\$ 2^{\circ}$ - Resp. n. 467.212/RJ, Rel. Min. Luiz Fux, in DJU de 28-10-03).

\subsection{Antinomias de normas estaduais versus normas privativas da União}

Conforme já frisado, para analisar a taxionomia de uma legislação em face da distribuição de competências constitucionais deve-se frisar sobretudo: i) o objeto jurídico que se está a tutelar pela legislação; ii) a finalidade da legislação frente à especificidade de seus regramentos, ou seja, sua natureza jurídica.

Nesse sentido, impera a necessidade de se buscar interpretações que conciliam os multicentros normativos próprios do federalismo, de modo a admitir a convivência harmônica dos poderes. Imperativo, portanto, romper os olhares rígidos das engrenagens de competências, justamente para facultar seu encaixe à luz dos valores constitucionais em jogo e o interesse federado em foco, a ser balizado pelo decantamento da jurisprudência em sintonia com os apontamentos da doutrina.

Assim, quando se deparar com entrechoques da legislação da União baseada na sua competência privativa, como o Direito Civil de um lado, e de outro normas fundadas nas competência residuais do Estado-membro ou mesmo na competência concorrente, a premissa 
inicial é justamente essa, qual seja, a necessidade de convívio entre as normas, de forma a visualizar aquelas como normas gerais e essas como especiais, desde que respeitada a preservação do núcleo essencial das disposições próprias daquelas, competências privativas, tais como os elementos próprios e essenciais do Direito Civil ou do Direito Eleitoral (art. 22, I, da Constituição Federal).

Esse raciocínio será ilustrado com exemplos práticos, pois no esteio dessa orientação tem decidido o STF em sede de controle concentrado - a teor da ADIn n 2938 - ao ratificar a constitucionalidade da Lei Mineira ${ }^{\circ}$ 13.454/00 que disciplina os procedimentos necessários à realização de eleições para implantação da Justiça de Paz, o que não invade a competência da União para legislar sobre Direito Eleitoral.

Entenderam os Ministros quanto a esse quesito do pedido que disposições de tal alçada não ferem o Direito Eleitoral, justamente porque não afrontam ou regulamentam as disposições próprias do Código Eleitoral.

Entendimento correlato é divisado também na ADI no 3000/CE onde se determinou através de lei estadual o acesso gratuito de policiais civis a estádios de futebol, consoante expressa a ementa do julgado:

EMENTA: CONSTITUCIONAL. POLICIAIS CIVIS. ESTÁDIOS: ACESSO GRATUITO. Lei 13.330, de 2003, do Estado do Ceará. CF, art. $5^{\circ}$, XIII. I. - Lei 13.330, de 2003, art. $1^{\circ}, \S 1^{\circ}$, do Estado do Ceará, que franqueia o acesso aos estádios de futebol do Estado apenas aos policiais e bombeiros em serviço no evento: constitucionalidade. II. - ADI julgada improcedente.

Como se percebe não se denota em tais casos inconstitucionalidade na legislação estadual, por ofensa ao Direito Civil ou Direito Eleitoral, pois não se regula normas próprias e específicas do Código Civil ou Eleitoral. Enfim, tais legislações são próprias da competência residual do Estado-membro que complementam seus interesses à luz das particularidades de cada Estado, de forma que devem se plasmar com flexibilidade perante as demais leis federais.

Outro exemplo eloqüente da jurisprudência endossa esse raciocínio. Cuida-se da competência legislativa remanescente dos Estados referente ao turismo. Assim, já decidiu o STF que o Estado de São Paulo tem de fato a prerrogativa de legislar (Decreto ${ }^{\circ}$ 29.912/89) sobre questões de turismo mesmo quando interagir indiretamente com transporte - pois o poder de polícia administrativa reclama regramento para regular o transporte, como o fretamento de ônibus de turismo no Estado, para proteção dos turistas e do próprio turismo, de 
sorte que não se visualiza ofensa à competência privativa da União para legislar sobre trânsito ${ }^{222}$

Esclareça-se que a competência legislativa sobre transportes é classificada como de cunho compartilhado, a teor dos preceitos constitucionais (arts. 22, IX, diretrizes da política nacional de transportes e 30, V, da CF). Logo, diante da própria semântica do enunciado do texto conferir à União a prerrogativa de estabelecer diretrizes para a política nacional de transporte, deve-se admitir o condomínio legislativo nessa seara.

A Suprema Corte admitiu, pois, o convívio de competências no âmbito do transporte, pois a União estabelece as diretrizes para a política nacional de transportes, ao passo que os Estados regulamentam o transporte intermunicipal e os Municípios executam o transporte municipal, e, por conseqüência, regulamentam essa atividade no âmbito da urbe.

Pode-se, pois, dizer que o objeto jurídico ora regrado e a repercussão das leis estaduais em estudo não abalam as leis federais (de competência privativa) sobre o assunto, de sorte que as legislações se harmonizam.

Nessa perspectiva, ponderamos que a mesma ratio seguiu a Lei Paulista ${ }^{223} n^{\circ} 7.844 / 92$ que concedera descontos de meia-entrada para estudantes, fundada na competência concorrente como expressão de Direito Econômico, da Cultura e do Desporto, forte no art. 24, I e IX da Constituição da República, pois patente a concretização de política pública de maior acesso à cultura e ao desporto aos estudantes. Nesse sentido foi o resultado da ADI $n^{\circ}$ $1.950 / \mathrm{SP}$, julgada improcedente pelo $\mathrm{STF}^{224}$.

\footnotetext{
${ }^{222}$ RE $\mathrm{n}^{\circ}$ 201.865-SP: EMENTA: CONSTITUCIONAL. ADMINISTRATIVO. ESTADO-MEMBRO: PODER DE POLÍCIA ADMINISTRATIVA. ÔNIBUS: FRETAMENTO PARA FINS TURÍSTICOS: DECRETO ESTADUAL REGULAMENTADOR. Decreto 29.912, de 1989, do Estado de São Paulo. I. - Fretamento de ônibus para o transporte com finalidade turística, ou para o atendimento do turismo no Estado. Transporte ocasional de turistas, que reclama regramento por parte do Estado-membro, com base no seu poder de polícia administrativa, com vistas à proteção dos turistas e do próprio turismo. $\mathrm{CF}, \operatorname{art} .25, \S 1^{\circ}$. Inocorrência de ofensa à competência privativa da União para legislar sobre trânsito e transporte (CF, art. 22, XI). II. - RE conhecido e não provido.

${ }^{223}$ Artigo $1^{\circ}$ - Fica assegurado aos estudantes regularmente matriculados em estabelecimentos de ensino da primeiro, segundo e terceiro graus, existentes no Estado de São Paulo, o pagamento de meia - entrada do valor efetivamente cobrado para o ingresso em casas de diversão, de espetáculos teatrais, musicais e circenses, em casas de exibição cinematográfica, praças esportivas e similares das áreas de esporte, cultura e lazer do Estado de São Paulo, na conformidade da presente Lei.

${ }^{224}$ EMENTA: AÇÃO DIRETA DE INCONSTITUCIONALIDADE. LEI N. 7.844/92, DO ESTADO DE SÃO PAULO. MEIA ENTRADA ASSEGURADA AOS ESTUDANTES REGULARMENTE MATRICULADOS EM ESTABELECIMENTOS DE ENSINO. INGRESSO EM CASAS DE DIVERSÃO, ESPORTE, CULTURA E LAZER. COMPETÊNCIA CONCORRENTE ENTRE A UNIÃO, ESTADOS-MEMBROS E O DISTRITO FEDERAL PARA LEGISLAR SOBRE DIREITO ECONÔMICO. CONSTITUCIONALIDADE. LIVRE INICIATIVA E ORDEM ECONÔMICA. MERCADO. INTERVENÇÃO DO ESTADO NA ECONOMIA.
} 
Deduz-se, assim, que uma vez estabelecida uma política pública do Estado rumo à concretização de um objetivo, albergado na competência do ente federado, tem-se como caracterizada a baliza para dar arrimo à competência supra apontada.

Eis o quesito de contribuição democrática própria do federalismo, pois o constitucionalismo tem-se debruçado para lapidar a ideia fundamental do federalismo que serve além do binômio de garantia da liberdade e eficiência dos entes federados, mas também da própria democracia. E tal assertiva é emblemática, porque diante de mais uma esfera de poder, o indivíduo está mais suscetível de participar na gestão da res pública.

Tribe evoca essa diretriz ao observar que ao âmbito da interpretação constitucional pende a necessidade que a Constituição estabeleça uma avaliação forte que favoreça a criação do máximo de opções políticas na falta de alguma proibição aplicável ${ }^{225}$ - como proibições específicas advindas de regras do ente central.

No esteio desse raciocínio, há fundamentos para a defesa da validade da competência dos Estados para legislarem sobre a restrição de cigarros, tal como estabelecido recentemente na forma da Lei Paulista n. 13.541/09, pois a norma em pauta tem arrimo direto na proteção e defesa da saúde, competência concorrente na forma do art. 24, XII, da Constituição da República.

De outra banda, vislumbram-se críticas ao julgado na ADI n ${ }^{\circ} 1.007 / \mathrm{PE}$ que rechaçou a Lei Pernambucana $n^{\circ} 10.983 / 93$, que regrava vencimento das mensalidades escolares para o fim de cada mês, pois à luz do princípio da especialidade - que rege a antinomia ora detectada - denota-se que a questão finca interesse na educação e no Direito Econômico, sem malferir as disposições de Direito Civil. Contudo, o STF, por maioria, entendeu que se cuida de Direito

ARTIGOS $1^{\circ}, 3^{\circ}, 170,205,208,215$ e 217, § $3^{\circ}$, DA CONSTITUIÇÃO DO BRASIL. 1. É certo que a ordem econômica na Constituição de 1.988 define opção por um sistema no qual joga um papel primordial a livre iniciativa. Essa circunstância não legitima, no entanto, a assertiva de que o Estado só intervirá na economia em situações excepcionais. 2. Mais do que simples instrumento de governo, a nossa Constituição enuncia diretrizes, programas e fins a serem realizados pelo Estado e pela sociedade. Postula um plano de ação global normativo para o Estado e para a sociedade, informado pelos preceitos veiculados pelos seus artigos $1^{\circ}, 3^{\circ}$ e 170 . 3. A livre iniciativa é expressão de liberdade titulada não apenas pela empresa, mas também pelo trabalho. Por isso a Constituição, ao contemplá-la, cogita também da "iniciativa do Estado"; não a privilegia, portanto, como bem pertinente apenas à empresa. 4. Se de um lado a Constituição assegura a livre iniciativa, de outro determina ao Estado a adoção de todas as providências tendentes a garantir o efetivo exercício do direito à educação, à cultura e ao desporto [artigos 23, inciso V, 205, 208, 215 e $217 \S 3^{\circ}$, da Constituição]. Na composição entre esses princípios e regras há de ser preservado o interesse da coletividade, interesse público primário. 5 . O direito ao acesso à cultura, ao esporte e ao lazer, são meios de complementar a formação dos estudantes. 6 . Ação direta de inconstitucionalidade julgada improcedente.

${ }^{225}$ TRIBE; DORF, 2007, p. 33. 
Civil e julgou procedente ação direta de inconstitucionalidade, baseada em vício formal da lei supra apontada, qual seja, a ausência de competência do Estado para tal disciplina.

Registre-se, pois, que se denota ofensa clara à legislação nacional quando o Estadomembro afrontar o cumprimento da legislação federal, privativa da União, quer ao regular diretamente a matéria em foco, quer ao dispor de modo residual, de forma a efetivamente comprometer o interesse federal em foco. Essa assertiva é endossada por Fernanda Dias Menezes de Almeida ao abordar antinomia entre a lei federal que autorizava a venda de álcool combustível adicionado de metanol, no esteio do art. 238 da CF, em oposição à lei estadual, lastreada na competência concorrente de proteção ao meio ambiente e à saúde que proibia a venda do combustível com aquele aditivo. Diz a autora:

\begin{abstract}
Quando o constituinte, não obstante conscientizado da importância de uma maior descentralização e colaboração entre os entes federativos, defere privativamente a um deles competência para normatizar determinada matéria, é porque haverá razões suficientes para a concentração da competência. (...) Não entendemos válida a proibição de sua venda pelos estados e municípios. Poderão estes, no exercício de sua competência concorrente suplementar, até mesmo estabelecer como obrigatória a observância de determinadas cautelas e providências na comercialização do produto. Não porém vedá-la, quando a União, titular exclusiva da competência legislativa em matéria de venda de combustíveis e titular da competência para expedir normas gerais sobre proteção ambiental e saúde, tiver liberado o produto ${ }^{226}$.
\end{abstract}

Em outras palavras, o citado exemplo corporifica a prioridade da legislação própria do ente federativo, a União para legislar sobre o assunto (seara dos combustíveis), cujas disposições devem preponderar sobre as demais em sentido contrário.

É o que eminente constitucionalista português J. J. Gomes Canotilho chama de princípio da conformidade funcional: "De acordo com este princípio, quando a Constituição regula de determinada forma a competência e função dos órgãos de soberania, estes órgãos devem manter-se no quadro de competências constitucionalmente definido, não devendo modificar, por via interpretativa (através do modo e resultado da interpretação) a repartição, coordenação e equilíbrio de poderes, funções e tarefas inerentes ao referido quadro de competências. $^{227}$

Nessa orientação tem se pautado a Suprema Corte dos EUA, que numa virada de posicionamento recente acabou reconhecendo a inconstitucionalidade de leis federais que

\footnotetext{
${ }^{226}$ ALMEIDA, 2007, p. 141-142.

${ }^{227}$ CANOTILHO, 2000, p. 533.
} 
fizeram as vezes da legislação estadual - vide o caso United States vs. Lopez (14 U.S. 549, 1995) como na tipificação de delitos, competência tipicamente estadual nos EUA, de forma que a Suprema Corte americana reconheceu a inconstitucionalidade de lei federal, e, assim, sublinhou a legitimidade da autonomia estadual no federalismo americano. ${ }^{228}$

\subsection{Tratados Internacionais e a Solução de Conflitos}

Nessa última etapa expor-se-á a competência material da União de firmar Tratados Internacionais e a consequiência legislativa daí decorrente para os entes federados; sua interpretação, aplicação jurídica aos Estados-partes, aos cidadãos e aos próprios entes federados.

Com efeito, os desdobramentos das normas dos Tratados Internacionais repercutem no encaixe das normas positivadas pelos demais entes federados, conforme posicionamento do Supremo Tribunal Federal em sede de controle abstrato de constitucionalidade de tais normas - como se verá. Daí a pertinência do exame do tema, já que a celebração dos Tratados Internacionais é espécie da competência material da União Federal com conseqüência nas competências legislativas.

O assunto apresenta relevo em razão do aumento expressivo dos tratados e convenções firmados pelo Brasil e da crescente demanda econômica internacional por segurança jurídica. Além disso, porque o Tratado é também espécie de norma jurídica da qual podem emanar direitos subjetivos aos nacionais de per si, e conseqüentemente obrigações aos entes federados.

Deveras, os anos que inauguram o novo milênio apontam novas perspectivas mundiais sociais, econômicas e políticas dinamizadas, sobretudo pelo intercâmbio mundial entre as nações em todos os níveis do saber humano e pelo destino mundial do comércio, que alcança consumidores de todas as nações. Esse fenômeno enfatiza a integração regional e comunitária

\footnotetext{
${ }^{228}$ GARCIA, Emerson. Conflitos entre normas constitucionais esboço de uma teoria geral. Rio de Janeiro: Lumen Juris, 2008, p. 507-508. Narra-se ainda, outra decisão tomada pela Suprema Corte americana, que reconheceu inconstitucionalidade de lei federal, no caso Printz vs. United States (521 U. S. 808, 1997) ao sublinhar a autonomia estadual na aplicação pelos funcionários estaduais do direito estadual em foco.
} 
entre as Nações. Essa revolução política cultural traz novas perspectivas para o Direito, em especial acarreta a proliferação de Tratados e Convenções Internacionais.

Nesse passo, o costume internacional, que por séculos foi fonte preponderante do Direito Internacional, somente se viu superado pela positivação de tratados a partir do século $\mathrm{XIX}^{229}$. Luis Eduardo Schoueri ${ }^{230}$ cita estudos estatísticos de Gonçalves Pereira e Fausto Quadros, onde se constata o fenômeno recente da proliferação dos Tratados Internacionais, pois de 1500 aC. a 1860 foram concluídos 8.000 tratados. Já de 1947 a 1984, foram firmados quase 40.000 tratados, de forma que as celebrações de tratados têm crescido expressivamente, sobretudo nos últimos anos.

Essa assertiva é ainda realçada pelo projeto de integração comunitária do MERCOSUL (atualmente ainda considerada pela doutrina majoritária como uma União Aduaneira imperfeita ${ }^{231}$ ), cujas normas e Protocolos projetam efeitos diretos aos nacionais do País.

Em outros termos, os Tratados do MERCOSUL, além de serem normas jurídicas primárias de Direito Internacional, presentes a situação fática que lhes dá vida, ensejam direitos subjetivos aos residentes dos países dos Estados-partes. Nesse sentido, Jan Kleinheisterkamp ${ }^{232}$ destaca o método da interpretação aplicável aos Tratados, em especial ao MERCOSUL, e pontua que as normas oriundas do Mercosul adquirem, pela internalização, qualidade de direito interno do respectivo Estado-parte, a serem aplicadas pelo juiz nacional.

Justamente em razão das dezenas de Tratados e Acordos para evitar a bitributação assinados pelo País, cerca de 29, além de outros referentes a Cooperação Econômica e Acordo de Cooperação Aduaneira (conforme aponta o sítio da Receita Federal), o presente trabalho fará uma interseção nessa temática para melhor explorar o assunto dos conflitos - até mesmo para os entes federados. Ademais, os Tratados Internacionais representam fonte de direito internacional cada vez mais presente na vida moderna e aos operadores do Direito, bem como

\footnotetext{
${ }^{229}$ RODAS apud SCHOUERI, Luis Eduardo. Tratados e convenções internacionais sobre tributação. IBDT Direito Tributário Atual. São Paulo: Dialética, n. 17, 2003, p. 20.

${ }^{230}$ SCHOUERI, 2003, p. 20.

231 CELLI JÚNIOR, Umberto. Teoria Geral da Integração: em busca de um modelo alternativo. In: MERCADANTE, Araminta de Azevedo; CELlI JÚNIOR, Umberto; ARAÚJO, Leandro Rocha de (Org.). Blocos econômicos e integração na América Latina, África e Ásia. Curitiba: Juruá, 2006, v.1, p. 19-37, p. 32.

${ }^{232}$ KLEINHEISTERKAMP apud RODAS RODAS, João Grandino (Coord.). Contratos internacionais. 3. ed. São Paulo: Revista dos Tribunais, 2002, p. 332-335.
} 
aos próprios entes federados que certamente devem respeito à normativa internacional, como será demonstrado.

A divisão entre tratado, acordo e convenção é imprecisa na doutrina e na prática consular. O termo tratado é geralmente utilizado para os acordos internacionais mais solenes e de conteúdo predominantemente político, enquanto os termos acordo, convenção e convênio, dentre muitos outros, se prestam a nomear instrumentos especializados em determinada matéria como a comercial ou a tributária ${ }^{233}$. De qualquer forma, tratados ou convenções são instrumentos de Direito Internacional Público, são suas fontes, ou seja, são vozes desse ramo do Direito, e como tal, seguem sua interpretação, bem como a sua aplicação.

O modo pelo qual os tratados e convenções internacionais adaptam-se ao direito é matéria reservada à Constituição de cada Estado. A Constituição da República não explicita o modo de recepção do Tratado ao ordenamento nacional; não rege diretamente sua seara jurídica. Trata do tema dos tratados no rol dos direitos e garantias fundamentais, nas atribuições dos Poderes, bem como no controle de constitucionalidade, respectivamente arts. $5^{\circ}, \S 3^{\circ} ; 49$, I; 84, VII e 103, III, b. Passamos, pois, à sua análise ${ }^{234}$.

A Constituição Federal destina preceito específico referente aos Direitos Humanos, introduzido pela $\mathrm{EC} \mathrm{n}^{\circ} 45$, que acrescentou in verbis: $\S 3^{\circ}$ Os tratados e convenções internacionais sobre direitos humanos que forem aprovados, em cada Casa do Congresso Nacional, em dois turnos, por três quintos dos votos dos respectivos membros, serão equivalentes às emendas constitucionais.

Vê-se, pois, que a própria Constituição Federal distingue os Tratados referentes aos Direitos Humanos dos demais, por certo, em face da repercussão histórica e da própria evolução dos Tratados de Direitos Humanos no Direito Internacional Público, que tem em mira garantir o exercício dos direitos da pessoa humana, consagrados sobretudo no pós-guerra. Sua evolução é delineada por declarações internacionais, em geral sem caráter vinculativo ${ }^{235}$, baseada em normas programáticas e compromissos internacionais em que os países signatários

\footnotetext{
233 BROTONS, Antônio Remiro et al. Derecho Internacional. Madrid: McGrawHill, 1997, p. 182.

${ }^{234}$ De início já se esclareça que não há cabimento na posição que acolhe a divisão de tratados-contratos e tratados-norma, pois a distinção de um e de outro não é contemplada pela Convenção de Viena ou de Havana, nem tampouco pela Constituição.

${ }^{235}$ Nesse sentido, Cf. ACCIOLY, Hidelbrando; SILVA, Geraldo Eulálio do Nascimento. Manual de direito internacional público. 12. ed. São Paulo: Saraiva, 1996, p. 368.
} 
reconhecem direitos humanos e os seus valores fundamentais - como ocorre com a Declaração Universal dos Direitos do Homem ${ }^{236}$.

Alexandre de Moraes pondera que a evolução dos direitos humanos é relativamente recente, iniciando-se com importantes declarações sem caráter vinculativo, para posteriormente assumir a forma de tratados internacionais, no intuito de obrigarem os países signatários ao cumprimento de suas normas ${ }^{237}$.

Diante da inovação constitucional positivada pela $E C \mathrm{n}^{\circ} 45$ é possível a incorporação do tratado ou convenção internacional com o status de emenda constitucional, se referente a direitos humanos, desde que submetido ao quorum e forma de aprovação próprios de emenda constitucional. Nesse sentido, ensina Anna Cândida da Cunha Ferraz que a inovação constitucional contida no $\S 3^{\circ}$ do artigo $5^{\circ}$ não cogitou de disciplinar matéria nova, mas de atribuir novo formato ou nova categoria aos tratados de direitos humanos, mediante procedimento específico, atribuindo agora status de equivalência constitucional aos tratados e convenções de direitos humanos aos quais se remete, com precisa abrangência ao futuro ${ }^{238}$.

Via de regra, os tratados e convenções internacionais incorporam-se ao ordenamento jurídico pátrio através de procedimento complexo com a atuação conjunta do Chefe de Estado e do Legislativo Federal que aqui representam a própria Federação, a República Federativa do Brasil. Como sabido, a República Federativa do Brasil é o ente soberano, titular de personalidade jurídica internacional. Contudo, a voz ou representação da República Brasileira no âmbito internacional é materializada pela União ${ }^{239}$ (que congrega in casu a vontade e interesse do Estado brasileiro), ex vi o disposto no art. 21, I, da Constituição da República: Compete à União manter relações com Estados estrangeiros e participar de organizações internacionais.

Logo, sob o prisma internacional a União (representada pelo Chefe de Estado ou por seus órgãos: Ministério de Relações Exteriores) age em nome da República Federativa do Brasil, e, como tal, representa todas as pessoas políticas internas. Tal constatação tem

\footnotetext{
${ }^{236}$ Assinada em Paris em 10 de dezembro de 1948 e subscrita pela Assembléia Geral das Nações Unidas pela Resolução n 217 A e assim pelo Brasil.

${ }^{237}$ MORAES, Alexandre de. Tratados internacionais na Constituição de 1988. In: AMARAL, Antonio Carlos Rodrigues (Coord.). Tratados internacionais na ordem jurídica brasileira. São Paulo: Lex Editora, 2005. p. 31 46.

${ }^{238}$ FERRAZ, Anna Cândida da Cunha. Os tratados e as convenções internacionais de direitos humanos anteriores à Emenda Constitucional n. 45/2004. Revista Mestrado em Direito, Osasco, v. 7, n. 1, p. 117-132, jan./jun. 2007. ${ }^{239}$ Nesse sentido são os comentários de Cintia Regina Béo. FERRAZ, Anna Cândida da Cunha. Constituição Federal interpretada: artigo por artigo, parágrafo por parágrafo. Barueri, SP: Manole, 2010, p. 142-143.
} 
expressiva importância para a articulação de competências entre os demais entes federados, pois poderão surgir dos Acordos Internacionais, obrigações gerais nas quais os demais entes federados deverão cumprir, eis que vinculadas em nome da Federação.

Como observa Michel Temer: o federalismo faz da União uma figura de duas faces, que tanto age em nome próprio como em nome da Federação ${ }^{240}$. Ora se manifesta por si, como pessoa jurídica de capacidade política, ora em nome do Estado Federal. Justamente por isso, surge importante viés interpretativo aos Tratados e Acordos internacionais, qual seja, a sua vinculação aos demais entes federados, pois a atuação da União na perspectiva internacional é realizada sob o manto da Federação que representa os demais entes federados.

Dispõe o art. 84, VII, da CF, que cabe ao Presidente da República celebrar tratados, convenções e atos internacionais, sujeitos a referendo do Congresso Nacional. A atuação do Presidente é a de Chefe de Estado, e como tal, representa a República, a nação brasileira para negociar e firmar os acordos, mas sua atuação é condicionada pela necessária aprovação do Congresso Nacional, consoante expressa o art. 49, I - resolver definitivamente sobre tratados, acordos ou atos internacionais que acarretem encargos ou compromissos gravosos ao patrimônio nacional.

A deliberação do Poder Legislativo é realizada primeiramente na Câmara dos Deputados e em seguida no Senado Federal. Sua aprovação é explicitada por um decretolegislativo, promulgado pelo Presidente do Senado Federal. Se recusado, o tratado internacional não vinga para o País. O Congresso Nacional, ao resolver o tratado, pode suprimir em parte ou integralmente as reservas que o Poder Executivo vinculou originalmente ao tratado, e mesmo adicionar outras reservas ao texto. Contudo, o texto em si do tratado não pode ser objeto de emendas dos parlamentares ${ }^{241}$. Tanto porque a tradição determina que o acréscimo de preceitos advém da negociação firmada pelos representantes dos Estados.

Por derradeiro, uma vez aprovado o tratado pelo Legislativo, a fase seguinte é a sua promulgação, através da edição de ato do Presidente da República, que promulga e publica o próprio tratado, tal como aprovado pelo decreto-legislativo, pela forma do Decreto comum. E, por isso, grande parte da doutrina ${ }^{242}$ considera que o ordenamento jurídico pátrio adotou o

\footnotetext{
${ }^{240}$ TEMER, 1993, p. 77.

${ }^{241}$ GODOI, 2003, p. 976-1010.

${ }^{242}$ Cf. G GODOI, Marciano Seabra. Os tratados ou convenções internacionais para evitar a dupla tributação e sua hierarquia normativa no direito brasileiro. In: SCHOUERI, Luis Eduardo et al (Coord.). Direito tributário -
} 
monismo moderado, eis que se aprova e se promulga o próprio tratado; não é necessária lei que edite os preceitos do tratado (dualismo) ${ }^{243}$.

Rezek ensina que o decreto de promulgação não constitui reclamo constitucional: ele é produto de uma praxe tão antiga quanto a Independência e os primeiros exercícios convencionais do Império. Cuida-se de um decreto, unicamente porque os atos do chefe do Estado costumam ter esse nome. Por nada mais. Vale aquele como ato de publicidade da existência do tratado ${ }^{244}$.

Fiel ao princípio republicano que demanda publicidade dos atos institucionais, é só a partir do decreto que o tratado adquire executoriedade interna - em sede internacional, dependerá dos contornos de cada tratado, prazo e necessidade de aprovação ou depósito do tratado - e se sujeita ao controle de constitucionalidade (CF, art. 103, III, b).

Já os tratados que não acarretam compromisso financeiros ao País (CF, art. 49, I), prescindem de aprovação do Congresso e seguem diretamente para publicação no Diário Oficial da União, autorizada pelo Ministro das Relações Exteriores, que garante a introdução na ordem jurídica nacional dos acordos celebrados no molde "executivo", em analogia ao modelo norte-americano que os qualifica como executive agreements.

Qualquer tratado ou convenção internacional é suscetível de controle de constitucionalidade difuso ou concentrado, expressamente previsto na Constituição da República, 103, III, b). Cuida-se de tradição do direito brasileiro em similitude com grande parte do direito comparado, dada a supremacia das normas constitucionais. É justamente essa a jurisprudência iterativa e atual de nossas Cortes Superiores, cujo deslinde do voto explicita com propriedade a relação de paridade normativa entre os atos internacionais e as leis ordinárias (normas infraconstitucionais de direito interno) - Adin $\mathrm{n}^{\circ}$ 1.480/DF, Rel. Celso de Mello, confirmada pelo Pleno, informativo $\mathrm{n}^{\circ} 135$ :

\footnotetext{
homenagem a Alcides Jorge da Costa. São Paulo: Quartier Latin, v. 2, p. 975-1010, 2003, p. 983-984. Adotaram o monismo com prevalência do direito internacional Hidelbrando Accioly, Vicente Ráo, Carlos Maximiliano, Marota Rangel, e Celso D. Alburquerque Mello. Ainda sobre o tema, Cf. Planejamento fiscal através de acordos de bitributação: Treaty Shopping, São Paulo: Revista dos Tribunais, 1995, p. 88-89.

${ }^{243}$ Contudo, pende expressiva polêmica acadêmica sobre o assunto, mas em ambas correntes atualmente firmamse posturas moderadas.

${ }^{244}$ REZEK, José Francisco. Direito internacional público. 7. ed. São Paulo: Saraiva, 1998, p. 84.
} 
Os tratados ou convenções internacionais, uma vez regularmente incorporados ao direito interno, situam-se, no sistema jurídico brasileiro, nos mesmos planos de validade, de eficácia e de autoridade em que se posicionam as leis ordinárias, havendo em conseqüência, entre estas e os atos de direito internacional público, mera relação de paridade normativa. Precedentes. No sistema jurídico brasileiro, os atos internacionais não dispõem de primazia hierárquica sobre as normas de direito interno. A eventual precedência dos tratados ou convenções internacionais sobre as regras infraconstitucionais de direito interno somente se justificará quando a situação de antinomia com o ordenamento doméstico impuser, para a solução do conflito, a aplicação de alternativo do critério cronológico (lex posterior derogat priori) ou, quando cabível, do critério da especialidade. Precedentes.

Enfim, a orientação do Supremo Tribunal Federal é admitir o controle de constitucionalidade de Tratados, pois se acata a premissa inerente ao Direito Constitucional que a Constituição é o fundamento de validade de todo o ordenamento jurídico, que será elaborado a partir dela e em conformidade com as suas disposições, de sorte que a recepção dos tratados se aloja no plano infraconstitucional - salvo se se cuidar de matéria referente a direitos humanos e sua aprovação seja submetida ao quorum e aprovação próprios de emenda constitucional na forma da $\mathrm{EC} \mathrm{n}^{\circ} 45$.

\subsubsection{Interpretação dos Tratados}

Salvo a exceção contida na $\mathrm{EC}^{\circ}$ 45, os tratados internacionais em regra subsumem-se ao sistema jurídico pátrio no âmbito infraconstitucional; suas normas apresentam, pois, paridade normativa entre a lei ordinária federal, conforme decidido no leading case RE 80.004/SE, cuja matéria versava sobre direito comercial, na qual admitiu-se que lei ordinária posterior modificasse preceito contido em tratado internacional.

Contudo, no âmbito tributário permanece o entendimento da prevalência dos tratados e convenções internacionais sobre a legislação tributária interna, tão somente por força do art. 98 do Código Tributário Nacional ${ }^{245}$, norma com status de lei complementar. Observa-se, entretanto, que o fenômeno deve ser compreendido baseado na interpretação hierárquica da própria lei complementar que define os limites da incidência tributária da lei impositiva, tal como delineado no art. 146, III, da Constituição Federal vinculante para todos os entes federados.

\footnotetext{
245 Art. 98. Os tratados e as convenções internacionais revogam ou modificam a legislação tributária interna, e serão observados pela que lhes sobrevenha.
} 
Outra peculiaridade tem-se quanto à interpretação dos Tratados referentes aos direitos fundamentais, conforme recente pronunciamento do STF sobre a eficácia do Pacto São José da Costa Rica, cujo art. 7 n. 7 veda a prisão civil salvo quanto ao inadimplemento voluntário e inescusável de obrigação alimentícia (excluindo o depositário infiel), de forma que o Supremo Tribunal Federal considerou o Pacto como incluso no art. $5^{\circ}, \S 2^{\circ}$, da $\mathrm{CF}^{246}$, e, assim, conferiu interpretação evolutiva às garantias fundamentais no sentido de que a partir de sua incorporação ao ordenamento jurídico pátrio não se admite prisão do depositário infiel, pois tais normas albergam status de supralegalidade, consoante noticiado no Informativo ${ }^{\circ} 531$ do $\mathrm{STF}^{247}$.

A referida decisão do STF é emblemática relativamente à história dos direitos fundamentais e representa importante passo evolutivo na interpretação das normas do gênero, sobretudo em face da inserção do $\S 3^{\circ}$ no art. $5^{\circ}$ da Constituição Federal, que conferiu base para interpretação de que os tratados referentes aos direitos humanos possuem carga axiológica que lhe confere status de supralegalidade em relação às leis ordinárias, consoante explicita o Ministro Gilmar Mendes no voto do HC $87585^{248}$.

\footnotetext{
${ }^{246} \S 2^{\circ}$ - Os direitos e garantias expressos nesta Constituição não excluem outros decorrentes do regime e dos princípios por ela adotados, ou dos tratados internacionais em que a República Federativa do Brasil seja parte.

${ }^{247}$ Em conclusão de julgamento, o Tribunal concedeu habeas corpus em que se questionava a legitimidade da ordem de prisão, por 60 dias, decretada em desfavor do paciente que, intimado a entregar o bem do qual depositário, não adimplira a obrigação contratual — v. Informativos 471, 477 e 498. Entendeu-se que a circunstância de o Brasil haver subscrito o Pacto de São José da Costa Rica, que restringe a prisão civil por dívida ao descumprimento inescusável de prestação alimentícia (art. $\left.7^{\circ}, 7\right)$, conduz à inexistência de balizas visando à eficácia do que previsto no art. 5, LXVII, da CF ("não haverá prisão civil por dívida, salvo a do responsável pelo inadimplemento voluntário e inescusável de obrigação alimentícia e a do depositário infiel;”). Concluiu-se, assim, que, com a introdução do aludido Pacto no ordenamento jurídico nacional, restaram derrogadas as normas estritamente legais definidoras da custódia do depositário infiel. Prevaleceu, no julgamento, por fim, a tese do status de supralegalidade da referida Convenção, inicialmente defendida pelo Min. Gilmar Mendes no julgamento do RE 466343/SP.

248“ (...) Não se pode negar, por outro lado, que a reforma também acabou por ressaltar o caráter especial dos tratados de direitos humanos em relação aos demais tratados de reciprocidade entre os Estados pactuantes, conferindo-lhes lugar privilegiado no ordenamento jurídico.

Em outros termos, solucionando a questão para o futuro - em que os tratados de direitos humanos, para ingressarem no ordenamento jurídico na qualidade de emendas constitucionais, terão que ser aprovados em quorum especial nas duas Casas do Congresso Nacional -, a mudança constitucional ao menos acena para a insuficiência da tese da legalidade ordinária dos tratados e convenções internacionais já ratificados pelo Brasil, a qual tem sido preconizada pela jurisprudência do Supremo Tribunal Federal desde o remoto julgamento do RE $n^{\circ}$ 80.004/SE, de relatoria do Ministro Xavier de Albuquerque (julgado em 1.6.1977; DJ 29.12.1977) e encontra respaldo em um largo repertório de casos julgados após o advento da Constituição de 1988. (...)

Por conseguinte, parece mais consistente a interpretação que atribui a característica de 'supralegalidade' aos tratados e convenções de direitos humanos. Essa tese pugna pelo argumento de que os tratados sobre direitos humanos seriam infraconstitucionais, porém, diante de seu caráter especial em relação aos demais atos normativos internacionais, também seriam dotados de um atributo de 'supralegalidade'.
} 
Os Tratados e Acordos Internacionais são fonte imediata do Direito Internacional Público, seara extraordinária do direito que tem características próprias condizentes à sua natureza jurídica tão peculiar. Entre essas a constatação de que a sociedade internacional é descentralizada, ao contrário do âmbito interno próprio dos demais ramos do direito, não há autoridade superior que efetive ou garanta a aplicação de suas normas. Ensina Rezek que por isso os Estados se organizam horizontalmente, e prontificam-se a proceder de acordo com normas jurídicas na exata medida em que estas tenham constituído objeto de seu consentimento. A criação das normas é, assim, obra direta de seus destinatários ${ }^{249}$.

Decorre daí relações de coordenação entre os aplicadores e destinatários das normas de Direito Internacional Público, ao passo que na relação jurídica interna firma-se a idéia de subordinação.

Releva dessas observações a pujança do compromisso efetivado pelo consentimento dos Estados, do primado do pacta sunt servanda, na força jurígena do próprio pacto celebrado segundo a palavra e o compromisso moral de seu cumprimento. Daí a notável importância da boa-fé objetiva ao cumprimento dos acordos e ao próprio princípio da reciprocidade que condiciona e equilibra as relações jurídicas dos Estados aos seus respectivos direitos e obrigações, premissas que devem nortear o jurista na interpretação dessa especial seara do direito. Essa observação é expressamente apontada nos considerandos da Convenção de Viena como universalmente reconhecidos, condições necessárias à manutenção da justiça e do respeito das obrigações resultantes dos Tratados, diante dos princípios da igualdade de direitos e autodeterminação dos povos, da igualdade soberana e independência de todos os Estados.

Como já frisado, o Direito Internacional Público é baseado essencialmente nos costumes e nos princípios gerais de direito. E, no século passado, cristalizou-se internacionalmente essas normas de conduta do Direito Internacional Público, através da Convenção de Viena de 1969, conhecida como Convenção sobre os Tratados de âmbito mundial. Já sua entrada em vigor só se iniciou em 1980 e atualmente tem a adesão de mais de 99 Estados.

\footnotetext{
Em outros termos, os tratados sobre direitos humanos não poderiam afrontar a supremacia da Constituição, mas teriam lugar especial reservado no ordenamento jurídico. Equipará-los à legislação ordinária seria subestimar o seu valor especial no contexto do sistema de proteção dos direitos da pessoa humana." (grifei)

249 REZEK, 1998, p. 1-3.
} 
E como delineia a praxe consular, apesar de o Brasil não ter aderido expressamente à Convenção de Viena (tal como os EUA e a França), suas normas são também aplicáveis ao País, pois as normas da Convenção de Viena ${ }^{250}$ são consideradas a concretização de relações costumeiras entre os Estados e referendadas pelos julgamentos internacionais.

Por outro lado, o Brasil é signatário da Convenção de Havana sobre o Direito dos Tratados, elaborada em 1928, promulgada no Brasil pelo Decreto $\mathrm{n}^{\circ}$ 18.596, de 22.10.1929. Contudo, essa Convenção limita-se a apenas oito países americanos (Brasil, Equador, Haiti, Honduras, Nicarágua, Panamá, Peru e República Dominicana). Assim, quanto a esses Estados aplica-se a Convenção de Havana, atentando-se que dentre esses países, apenas o Equador firmou com o Brasil Acordo para evitar a bitributação.

Assim, por importância histórica e repercussão geopolítica, a primeira diretriz para a interpretação dos Tratados ou Convenções Internacionais é a Convenção de Viena, que detalha até mesmo as fases de negociação, da efetiva celebração do compromisso internacional e a interpretação jurídica dos Tratados e Acordos internacionais, justamente para amparar o compromisso original estabelecido entre os Estados, na busca da manutenção do sinalagma do acordo de vontades e de seu propósito, que deu ensejo à negociação internacional. Na mira desse vetor, a Convenção de Viena prescreve preceitos relativos à interpretação, dos quais merecem destaque os seguintes:

\section{Parte III \\ OBSERVÂNCIA, APLICAÇÃO E INTERPRETAÇÃO DE TRATADOS Seção I - OBSERVÂNCIA DE TRATADOS}

Art. 26

\section{Pacta sunt servanda}

Todo tratado em vigor obriga as partes e deve ser cumprido por elas de boa fé. Art. 27

Direito Interno e observância de tratados

Uma parte não pode invocar as disposições de seu direito interno para justificar o descumprimento de um tratado. Esta regra não prejudica o artigo 46. (...)

Seção 3 - INTERPRETAÇÃO DE TRATADOS

\section{Artigo 31}

1. Um tratado deve ser interpretado de boa fé, segundo o sentido comum dos termos do tratado em seu contexto e à luz de seu objeto e finalidade.

2. Para fins de interpretação de um tratado, o contexto compreende, além do texto, seu preâmbulo e anexos:

\footnotetext{
${ }^{250}$ A Convenção de Viena representa a codificação do Direito dos Tratados, baseados na prática reiterada da convivência diplomática, assinada em Viena aos 23 de maio de 1969. Só entrou em vigor aos 27 de janeiro de 1980, quando obteve o quorum mínimo, previsto na Convenção, de 35 Estados-partes.
} 
a) qualquer acordo relativo ao tratado e feito entre todas as partes por ocasião da conclusão do tratado;

b) qualquer instrumento estabelecido por uma ou várias partes por ocasião do tratado e aceito pelas outras partes como instrumento relativo ao tratado.

c) Será levado em consideração, juntamente com o contexto:

Artigo 33

Interpretação de tratados autenticados em duas ou mais línguas

1. Quando um tratado foi autenticado em duas ou mais línguas, seu texto faz igualmente fé em cada uma delas, a não ser que o tratado disponha ou as partes concordem em que, em caso de divergência, um texto determinado prevalecerá.

2. Uma versão do tratado em língua diversa daquelas em que o texto foi autenticado só será considerado texto autêntico se o tratado o previr ou as partes nisso concordarem.

3. Presume-se que os termos do tratado têm o mesmo sentido nos diversos textos autênticos.

4. Salvo o caso em que um texto determinado prevalece, nos termos do parágrafo 1, quando a comparação dos textos autênticos revela uma diferença de sentido que a aplicação dos artigos 31 e 32 não elimina, adotar-se-á o sentido que, tendo em conta o objeto e finalidade do tratado, melhor concilie esses textos.

\section{Seção 4 - TRATADOS E TERCEIROS ESTADOS}

\section{Artigo 34}

Regra geral sobre terceiros Estados

Um tratado não cria nem obrigações nem direitos para um terceiro Estado sem seu consentimento.

Como se vê, diante das peculiaridades do Direito Internacional Público fundado essencialmente no livre consentimento dos Estados na busca da cooperação entre as nações, os preceitos da Convenção de Viena expressamente apontam para o cumprimento do consensualismo do pacto e na valorização da boa-fé contratual, de forma que se dá especial ênfase à interpretação teleológica, tal como estabelece o art. 31, segundo o sentido comum dos termos e à luz de seu objeto e finalidade, conforme o encadeamento leal das negociações (anteriores e posteriores) e até mesmo a prática reiterada dos Estados relativo à interpretação do Tratado - art. 31, 3, b) supra.

A boa-fé objetiva ${ }^{251}$ funciona como uma válvula do sistema jurídico, nele introduzindo o elemento ético, impondo deveres de lealdade recíproca, correção, transparência e servindo

\footnotetext{
${ }^{251}$ A boa-fé objetiva repousa na idéia original traçada por Rousseau, segundo a Teoria do Contrato Social, que firma o conceito sociológico de Estado, quer para amparar a confiança dos súditos contratantes quer para reforçar a proibição do venire contra factum proprium - a proibição de ir contra os próprios atos, de forma a sufragar a obrigação do sujeito titular de direitos ou prerrogativas públicas de respeitar a aparência criada por sua própria conduta anterior nas relações jurídicas subseqüentes, ressalvando a confiança gerada em terceiros.
} 
como cânone hermenêutico-integrativo dos contratos. Apesar de sua aplicação mais ressaltada ser nos contratos, é certo que a eles não se restringe, devendo orientar as pessoas em quaisquer tipos de relações que travam com outrem. O seu núcleo essencial, segundo Karl Larenz, é a obrigação de não trair a confiança depositada ou dela abusar, já que esta é a base indispensável de todas as relações humanas ${ }^{252}$.

Assim, a boa-fé contratual há de ser interpretada como princípio coordenador de regras, eis que resguarda na pós-modernidade papel fundamental ao Direito.

Consagra-se ainda a expressão comum dos termos, tal como determinado em seu contexto, de sorte que a ressalva para entendimento especial deverá ser expresso, e na dúvida deve-se dar primazia pelo sentido que melhor reflita o objeto e o propósito do Tratado.

Portanto, a interpretação do Tratado deverá ser firmada segundo as normas de direito internacional, conforme aponta a teoria da adoção, segundo a qual o fato de uma norma ser aplicável no direito interno de um Estado contratante não lhe faz perder sua natureza internacional $^{253}$. Ora somente assim, ter-se-á preservado o princípio do consensualismo contratual entabulado entre as partes na elaboração do tratado ou do acordo internacional.

Tal constatação estende-se para o Direito Comunitário que também clama pela autonomia interpretativa dos métodos de Direito Internacional, considerando que a ratio conventionis é elaborada principalmente com enfoque nos próprios tratados, independentemente de quaisquer peculiaridades nacionais que possam ser inconsistentes com a uniformidade, conforme pontua Jan Kleinheisterkamp ao parafrasear Dietrich ${ }^{254}$.

Eis as premissas que a interpretação dos Tratados e Acordos internacionais devem seguir para a desafiante tarefa de tomar a regra abstrata e encontrar a solução aplicável à situação concreta, posto que não se pode interpretar nenhum texto jurídico a não ser colocando-o em relação com problemas jurídicos concretos. Porque é somente na sua aplicação aos fatos da vida e na concretização, que assim necessariamente se processa, que se

\footnotetext{
${ }^{252}$ LARENZ, Karl. Derecho de obligaciones. Madri: Revista de Derecho Privado, 1958, p. 142.

${ }^{253}$ SCHOUERI, Luis Eduardo. Notas sobre os Tratados Internacionais sobre tributação. In: AMARAL, Antonio Carlos Rodrigues. Tratados Internacionais na Ordem Jurídica Brasileira. São Paulo: Lex Editora, 2005, p. 189241.

${ }^{254}$ DIETRICH apud KLEINHEISTERKAMP, Jan. A interpretação uniforme do direito comunitário. In: RODAS, João Grandino (Coord.). Contratos Internacionais. 3 ed. Revista dos Tribunais, 2002, p. 351.
} 
revela completamente o conteúdo significativo de uma norma e ela cumpre a sua função de regular situações concretas ${ }^{255}$.

Nessa esteira, compartilha-se o entendimento do caráter necessário da atividade interpretativa, de forma a desacreditar no velho brocardo interpretatio cessat in claris, pois como é sabido, a aplicação do direito é infinitamente mais criativa que a mente do legislador, que evidentemente não contempla todas as soluções reais para a vida, sobretudo na hermenêutica constitucional que utiliza valores fluidos, bem como no próprio contexto do Direito Internacional que muitas vezes trabalha com a interpretação de normas de outras normas, com grau de abstração em segundo grau, como o caso do Direito Tributário Internacional nos acordos de bitributação ${ }^{256}$.

Essa observação destaca-se na tarefa de aplicação do caso concreto em eventual conflito com a lei interna, onde a tarefa do aplicador é eleger uma das normas em conflito, segundo os critérios da hermenêutica constitucional e da teoria geral do direito. Por isso, a inexistência de contradições intra-sistêmicas não é condição sine qua non para estrutura sistêmica do jurídico, mas a coerência (inexistência de antinomias) é imprescindível para o ato de aplicação do direito, conforme pontua Heleno Torres. E conclui que é da lógica operacional do sistema que somente no ato de aplicação pode-se definir a norma válida aplicável ao caso concreto, mediante decisão entre eventuais contradições normativas ${ }^{257}$.

Nesse particular, defende-se a primazia ao critério "especialidade", baseado evidentemente na comparação entre as normas e o tratado, sob o aforismo lex posterior generalis non derogat priori specilalli - partindo da premissa que o tratado por sua peculiaridade ínsita seja a lei especial. Vale aqui a lição de Bobbio: com base nessa regra, o conflito entre critério de especialidade e critério cronológico deve ser resolvido em favor do primeiro: a lei geral sucessiva não tira do caminho a lei especial precedente ${ }^{258}$.

Relevante, portanto, traçar os limites da interpretação justamente para que a atividade interpretativa não se perca no relativismo. Conforme ensina Emilio Betti, o sentido há de ser extraído ou provir das formas significativas, e não introduzido nas objetivações do espírito

\footnotetext{
${ }^{255}$ LARENZ, Karl. Metodologia da ciência do direito. Lisboa: Fundação Calouste Gulbenkian, 1978, p. 396.

${ }^{256}$ Nesse sentido, SCHOUERI, 2003, p. 36.

${ }^{257}$ TORRES, Heleno T. Aplicação dos tratados e convenções internacionais em matéria tributária no direito brasileiro. In: AMARAL, Antonio C. R. (Coord.). Tratados internacionais na ordem jurídica brasileira. São Paulo: Lex Editora, 2005, p. 160.

${ }^{258}$ BOBBIO, 1999, p. 108.
} 
humano de modo arbitrário - sensus non est inferendus sed efferendus. E as formas significativas têm de ser consideradas autônomas e compreendidas de acordo com a sua própria lógica de desenvolvimento, coerência e racionalidade ${ }^{259}$.

Essa constatação estende-se aos Tratados e Acordos internacionais, segundo as premissas de interpretação supra apontadas, em especial os preceitos dos artigos 31 a 33 da Convenção de Viena, segundo a lógica de desenvolvimento, criação e comportamento da norma advinda do tratado internacional - sua coerência e finalidade, frente aos problemas que surgirem da realidade concreta, até como medida de guarnecer a confiança e leal expectativa traçada pelas partes.

Para efeito de ilustração, apontar-se-á um caso específico e relevante ao tema (tratados internacionais), os tratados para evitar a bitributação, tema escolhido em razão do número ${ }^{260}$ de acordos desse gênero já firmados pelo País e pela necessidade de interpretação uniforme de seus preceitos pelos Estados partes e pelos próprios entes federados - e pela riqueza jurídica que a temática proporciona, até mesmo aos entes políticos.

O fenômeno da bitributação ocorre pela simultânea coincidência de mais de uma pretensão tributária de entes soberanos, em face do mesmo contribuinte, sobre o mesmo fato imponível (situação do mundo concreto descrito na norma impositiva tributária). Diante dos perversos efeitos econômicos da bitributação há muito se discute a mitigação de tais efeitos, que muitas vezes conspurcam o patrimônio do contribuinte com matizes de confisco; impedem o investimento seguro internacional e dificultam o crescimento econômico de países em desenvolvimento. Basta assim imaginar a dupla tributação da renda do contribuinte com alíquotas elevadas, o que ensejaria a tributação de mais da metade de sua renda bruta ${ }^{261}$.

\footnotetext{
${ }^{259}$ BETTI, Emílio. La interpretación da la ley y de los actos jurídicos. Madrid: EDERSA, 1975.

${ }^{260}$ O sítio da Receita Federal na internet arrola todos os Acordos para Evitar a Dupla Tributação já firmados pelo Brasil com os seguintes países: África do Sul, Alemanha (já denunciado), Argentina, Áustria, Bélgica, Canadá, , Chile, China, Coréia, Dinamarca, Equador, Espanha, Filipinas, Finlândia, França, Holanda, Hungria, Índia, Israel, Itália, Japão, Luxemburgo, México, Noruega, República Checa, Suécia e Ucrânia.

${ }^{261}$ Por essa razão, há vozes que pregam que a bitributação tem conotação de ilegitimidade perante a ordem jurídica internacional, quer baseado no resguardo do direito de propriedade, quer no direito da igualdade, internacionalmente reconhecidos na Declaração dos Direitos do Homem. Como decorre do discurso proferido por Wilhelm Kann em 1961, em Viena, citado por Schoueri, onde defende a ilegitimidade da bitributação diante do seu efeito confiscatório diretamente baseado no direito de propriedade, e daí a obrigação dos Estados-partes adotarem medidas contra a bitributação. Cf. Vorstand des Oesterreichischen Juristentages, 196, apud SCHOUERI, 2005, p. 192-193.
} 
Há algumas medidas unilaterais que mitigam os efeitos da bitributação aos contribuintes, como a política da isenção de uma taxação calcada na reciprocidade ${ }^{262}$, contudo o instituto jurídico mais eficiente para alcançar efeitos sólidos e previsíveis aos contribuintes e investidores é o tratado ou o acordo de bitributação, cuja projeção política ganhou voga a partir da Primeira Guerra Mundial, impulsionada inicialmente pela Sociedade das Nações em 1921, através dos trabalhos empreendidos por um grupo de experts, que culminou num relatório pioneiro e modelo de convenção para evitar a bitributação. Esses trabalhos firmaram a base dos estudos para as Convenções-Modelo de maior importância na geopolítica mundial $^{263}$ : a Convenção-Modelo da OCDE (Organização para Cooperação Econômica Européia).

Apesar de o Brasil não fazer parte dessa Organização Internacional, pactuou a maior partes dos Tratados a partir desse modelo, cuja projeção é de expressiva repercussão em termos de perspectivas globais. Douglas Yamashita ${ }^{264}$ pontua que até 1977, 179 acordos inspiraram-se nesta Convenção-Modelo da OCDE de 1963.

A maioria dos Acordos firmados pelo País seguiu em linhas gerais a Convençãomodelo da $\mathrm{OECD}^{265}$ que por sua vez aponta interessantes diretrizes para a sua interpretação; descreve os contribuintes e os tributos sujeitos ao Acordo; tece definições próprias sobre o que se entende por residência, empresa permanente, empresas associadas e outros importantes conceitos; arrola as regras de qualificação tributária aos fatos (dividendos, royalties, ganhos de capital, rendimento imobiliário, lucros das empresas); define os métodos para evitar a

\footnotetext{
${ }^{262}$ O Brasil não é signatário de nenhum tratado de bitributação com os EUA, contudo impera a reciprocidade de tratamento para a isenção de impostos federais entre o País e os EUA - reconhecido em ato administrativo da Receita Federal (Atos Declaratórios n 28/00 e 48/00), nos termos do art. 103 do Decreto 3000 (RIR):

Art. 103. As pessoas físicas que declararem rendimentos provenientes de fontes situadas no exterior poderão deduzir, do imposto apurado na forma do art. 86, o cobrado pela nação de origem daqueles rendimentos, desde que (Lei n- 4.862, de 1965, art. 5-, e Lei n- 5.172, de 1966, art. 98):

I - em conformidade com o previsto em acordo ou convenção internacional firmado com o país de origem dos rendimentos, quando não houver sido restituído ou compensado naquele país; ou

II - haja reciprocidade de tratamento em relação aos rendimentos produzidos no Brasil.

${ }^{263}$ Há ainda outras Convenções-modelo importantes, como a da ONU e a dos EUA.

264 YAMASHITA, Douglas. Evolução da convenção-modelo da OCDE e a Influência de suas alterações na Interpretação nos Tratados para evitar a bitributação. In: AMARAL, Antonio (Coord.). Tratados Internacionais na ordem Jurídica Brasileira. São Paulo: Lex Editora, 2005, p. 105.

265 O papel da Convenção-Modelo é de expressiva importância sobre os efetivos Tratados e Acordos Internacionais assinados pelos Estados, pois toda negociação parte do modelo jurídico desenhado, debatido e em constante estudo pela doutrina do Direito Tributário Internacional, de sorte que a interpretação desses últimos tem grande relevância sobre os Tratados concretos, pois a prática consular ratifica os modelos já estruturados com raras exceções. Contudo, a interpretação legítima advém do próprio Tratado que efetiva especificamente a vontade dos Estados contratantes.
} 
bitributação: a isenção ou a dedução; bem como apresenta hipótese do procedimento amigável e a troca de informações entre os Estados.

A rigor, a maioria dos tratados internacionais para evitar a bitributação apresenta normas de renúncia ou de repartição de competência tributária, aplicáveis a cada regra do tratado, a uma espécie de rendimento, de forma que cada espécie de rendimento firmará regra que cabe ao Estado da fonte ou ao Estado de residência do contribuinte. Ex. no modelo da OECD, o pagamento a título de royaltie tem sua tributação reservada ao país de residência do contribuinte, ao passo que o trabalho autônomo é tributado no país da fonte onde o rendimento é pago.

As normas dos tratados de bitributação são, assim, classificadas como normas de estrutura, pois ora veiculam normas de reconhecimento de competência, que estabelece qual ou quais dos Estados signatários terão competência para a tributação, caso estabeleça competência cumulativa de mais de um Estado signatário, ora normas de limitação de competência, que estabelecem regras para o exercício da competência concorrente destes $\operatorname{Estados}^{266}$.

Complexa, portanto, a tarefa de interpretação e da qualificação do fato imponível, pois a natureza das normas dos tratados que evitam a bitributação refere-se a normas sobre aplicação de normas, como ensina Vogel ${ }^{267}$. Prossegue o mestre de Munique ao afirmar que as normas dos acordos de bitributação não disciplinam a aplicação de um direito estrangeiro, como normas de colisão do Direito Internacional Privado, mas elas limitam o próprio direito interno dos Estados Contratantes. Daí a conclusão de Schoueri, ${ }^{\mathbf{2 6 8}}$ segundo a qual, os tratados internacionais não revogam a legislação interna; apenas prevalecem. Esta continua válida, mas tem sua aplicação contida pelo tratado internacional, em um processo de autolimitação desenvolvido pelo próprio Estado soberano, tendo em vista o acordado com outro Estado.

\footnotetext{
${ }^{266}$ XAVIER, Alberto. Direito tributário internacional. 6. ed. Rio de Janeiro: Forense, 2004a, p. 421.

267 VOGEL, Klaus. Problemas na interpretação de acordos de bitributação. In: SCHOUERI, Luis Eduardo (Coord.). Direito tributário - homenagem a Alcides Jorge da Costa. São Paulo: Quartier Latin, 2003, v. 2, p. 961 973.

${ }^{268}$ SCHOUERI, 2003, p. 35.
} 
Emblemática a metáfora de $\operatorname{Vogel}^{\mathbf{2 6 9}}$, ao comparar o tratado internacional de bitributação a uma máscara sobre a face do direito interno, deixando transparecer apenas as partes descobertas, e assim, aplicáveis na ordem internacional apenas os feixes que permanecessem visíveis.

Vê-se, pois, que a interpretação do acordo de bitributação é um raciocínio que se encerra em si mesmo, não se confundindo com a interpretação da lei interna. Nessa linha, o aplicador da lei deve concretizar os dois processos interpretativos de modo completamente independente, pois o aplicador do tratado indagará se o Estado contratante está autorizado a fazer incidir sua tributação sobre determinada situação. Enquanto que o intérprete da lei interna fará a pergunta de qual o montante da tributação sobre determinada situação. Note-se que as perguntas estão em planos diversos, tal como a máscara e o texto ${ }^{270}$.

\subsubsection{A Aplicação dos Tratados frente aos Entes Federados}

Tratar-se-á aqui da aplicação dos tratados em cotejo com a lei interna; seus conflitos e possíveis soluções para sua aplicação. Para tanto, necessário destacar alguns preceitos de maior importância para a interpretação referente a possíveis conflitos de competências entre os entes federados, advindos dos arts. 2.4 e 3.2 da Convenção-Modelo da OECD ${ }^{271}$, bem como alguns casos para ilustrar melhor o raciocínio jurídico de soluções de conflitos. O primeiro

269 VOGEL, Klaus. Harmonia decisória e problemática da qualificação nos acordos de bitributação. In: SCHOUERI, Luís Eduardo; ZILVETI, Fernando Aurélio (Coord.). Direito tributário - estudos em homenagem a Brandão Machado. São Paulo: Dialética, 1998, p. 72-73.

${ }^{270}$ SCHOUERI, 2003, p. 35

${ }^{271}$ Segue a versão original em inglês do Convenção-Modelo OECD. Article 2 TAXES COVERED:

1. This Convention shall apply to taxes on income and on capital imposed on behalf of a Contracting State or of its political subdivisions or local authorities, irrespective of the manner in which they are levied.

2. There shall be regarded as taxes on income and on capital all taxes imposed on total income, on total capital, or on elements of income or of capital, including taxes on gains from the alienation of movable or immovable property, taxes on the total amounts of wages or salaries paid by enterprises, as well as taxes on capital appreciation.

3. The existing taxes to which the Convention shall apply are in particular:

a) (in State $A)$ :

b) (in State B):

4. The Convention shall apply also to any identical or substantially similar taxes that are imposed after the date of signature of the Convention in addition to, or in place of, the existing taxes. The competent authorities of the Contracting States shall notify each other of any significant changes that have been made in their taxation laws. - A tradução retrata-se no próprio Tratado apontado no texto principal. 
desses preceitos define a regra de extensão aos tributos albergados pelo Acordo de Bitributação, expresso na maior parte dos tratados do gênero assinados pelo País, conforme destaca o Acordo assinado com a Espanha, publicado no Decreto $\mathrm{n}^{\mathrm{o}} 76.975 / 76$, item 2.4 (grifei):

\author{
ARTIGO 2 \\ Impostos visados
}

1.A presente Convenção se aplica aos impostos sobre a renda exigidos por um dos Estados Contratantes, qualquer que seja o sistema usado para a sua exação.

2, Consideram-se impostos sobre a renda aqueles que incidem sobre a totalidade da renda ou sobre parte da mesma, inclusive os impostos provenientes da alienação de bens móveis ou imóveis, os impostos sobre o montante dos salários pagos pela empresa (não se incluindo as cotas de Previdência Social), assim como os impostos sobre as mais-valias.

3, Os impostos atuais aos quais se aplica a presente Convenção são:

a) no Brasil:

- O Imposto de renda com exclusão das incidências sobre remessas excedentes e atividades de menor importância (doravante referido como "imposto brasileiro");

b) na Espanha:

(i) o imposto geral sobre a renda das pessoas físicas;

(ii) o imposto geral sobre a renda de sociedades e demais entidades jurídicas, com inclusão do imposto especial de 4\% estabelecido pelo artigo 104 da Lei $n^{\circ} 41 / 1964$, de 11 de junho;

(iii) os seguintes impostos a conta: a contribuição territorial sobre a riqueza rural e pecuária. a contribuição territorial, sobre a riqueza urbana, o imposto sobre os rendimentos do trabalho pessoal, o imposto sobre a renda do capital e o imposto sobre atividades e lucros comerciais e industriais;

(iv) no Sahara, os impostos sobre a renda (sobre os rendimentos do trabalho e do patrimônio) e sobre os lucros das empresas;

(v) o "canon" de superfície, o imposto sobre o produto bruto e o imposto especial sobre os lucros, regidos pela Lei n,o 21/1974, de 27 de junho, sobre pesquisa e exploração de hidrocarbonetos;

(vi) os impostos de renda locais (doravante referidos como "imposto espanhol").

4. Esta Convenção também será aplicável a quaisquer impostos idênticos ou substancialmente semelhantes que foram posteriormente criados seja em adição aos impostos já existentes, seja em sua substituição. As autoridades competentes 
dos Estados Contratantes notificar-se-ão de qualquer modificação significativa que tenha sido introduzida em suas respectivas legislações fiscais.

Em face da natureza do Acordo de Bitributação pautar-se na divisão tipológica dos tributos e não marcar definição direta às contribuições tributárias, é natural que a interpretação do art. 2.4 faça-se pela ótica do núcleo da hipótese de incidência, baseada no conceito tipológico do tributo, para averiguar se eventual tributo a ser criado deriva da tipologia constitucional e infraconstitucional da renda. Essa interpretação é marcante e de crucial importância para os tributos a serem criados, eis que assim divisa os tributos que serão albergados pelo Acordo de Bitributação e aqueles que não serão. Daí a importância da análise da data da assinatura dos Acordos, de seu contexto e do histórico do Acordo.

Relevante observar, assim, que os tributos a serem alcançados pelos Acordos de Bitributação são aqueles afirmados pela nação signatária, pessoa jurídica de direito internacional que representa evidentemente suas entidades políticas federadas ou administrativas. Logo, quer se trate de tributo federal, estadual ou municipal, uma vez firmado o Acordo para se evitar a Bitributação que contemple tais e quais tributos, esse é vinculante para o Fisco Federal, Estadual ou Municipal, quer em razão da natureza da vinculação no âmbito internacional firmar-se pela República Federativa do Brasil, quer em razão do disposto no artigo 98 do Código Tributário Nacional.

Nesse sentido é o posicionamento por unanimidade do Supremo Tribunal Federal (RE 229.096), que sufragou o Acordo da Ordem Mundial de Comércio, onde se discutia a isenção do ICMS (imposto estadual). No voto dos Ministros destaca-se que não há falar em isenção heterônoma, pois em sede internacional é a República Federativa do Brasil que se faz presente e, como tal, representa os demais entes federativos. Eis a síntese do julgado pelo STF:

EMENTA: DIREITO TRIBUTÁRIO. RECEPÇÃO PELA CONSTITUIÇÃO DA REPÚBLICA DE 1988 DO ACORDO GERAL DE TARIFAS E COMÉRCIO. ISENÇÃO DE TRIBUTO ESTADUAL PREVISTA EM TRATADO INTERNACIONAL FIRMADO PELA REPÚBLICA FEDERATIVA DO BRASIL. ARTIGO 151, INCISO III, DA CONSTITUIÇÃO DA REPÚBLICA. ARTIGO 98 DO CÓDIGO TRIBUTÁRIO NACIONAL. NÃO CARACTERIZAÇÃO DE ISENÇÃO HETERÔNOMA. RECURSO EXTRAORDINÁRIO CONHECIDO E PROVIDO. 1. A isenção de tributos estaduais prevista no Acordo Geral de Tarifas e Comércio para as mercadorias importadas dos países signatários quando o similar nacional tiver o mesmo benefício foi recepcionada pela Constituição da República de 1988. 2. O artigo 98 do Código Tributário Nacional "possui caráter nacional, com eficácia para a União, os Estados e os 
Municípios" (voto do Ministro Ilmar Galvão). 3. No direito internacional apenas a República Federativa do Brasil tem competência para firmar tratados (art. 52, § $2^{\circ}$, da Constituição da República), dela não dispondo a União, os Estados-membros ou os Municípios. O Presidente da República não subscreve tratados como Chefe de Governo, mas como Chefe de Estado, o que descaracteriza a existência de uma isenção heterônoma, vedada pelo art. 151, inc. III, da Constituição. 4. Recurso extraordinário conhecido e provido.

Essa decisão é marcante para as diretrizes nacionais, pois em sintonia com os compromissos internacionais do MERCOSUL, as relações comerciais da Organização Mundial do Comércio e o compromisso internacional de lealdade contratual, preconizado no art. 27 da Convenção de Viena.

Daí se concluir para o âmbito da interpretação dos Acordos de Bitributação: i) a prevalência $^{272}$ aos tratados internacionais sobre a lei interna, inclusive sobre as normas dos demais entes federados; ii) somente a lei interna é que veicula a norma de incidência tributária, sendo outro o papel do tratado internacional; iii) os tratados internacionais têm sistemática própria de interpretação, tal como delineado acima.

Quanto às demais áreas do Direito, o Tratado Internacional firmado pelo Brasil também é vinculativo para toda a Federação, interpretação que decorre do próprio compromisso da Constituição Federal, nos termos do arts. $4^{\circ}$, IX e $5^{\circ}$, $\S 2^{\circ}$, tanto porque a representatividade do Tratado é firmada pela Nação Brasileira na pessoa do Presidente da República, que o faz na forma de Chefe de Estado. O compromisso internacional vincula, pois, todos os entes federados.

\footnotetext{
${ }^{272}$ Contudo, essa orientação não é vinculativa para outros domínios além do Direito Tributário (em razão do art. 98 do CTN), pois a jurisprudência equipara os Tratados ao nível hierárquico da lei ordinária, embora em planos distintos, essa na ordem interna, aquele no âmbito internacional. De qualquer sorte, propugna-se pela solução dos conflitos pelo critério da especialidade.
} 


\section{CONCLUSÕES}

Ao longo do exame do federalismo no Brasil, consagrado pela Constituição de 1988, é possível extrair, quanto ao tema objeto da dissertação, algumas conclusões que não esgotam, convém que se registre, toda a problemática examinada no texto.

O federalismo é fenômeno histórico, político e jurídico de divisão de competências legislativas e administrativas entre os entes políticos do Estado. A Constituição de 1988 firma a forma de Estado, baseada na descentralização jurídica e política do poder no âmbito territorial desse Estado, ao conferir autonomia aos entes políticos e soberania ao Estado Federal.

O federalismo brasileiro, na Constituição da República Federativa de 1988, se apresenta como um federalismo de equilíbrio, no qual as competências dos entes federados União, Estados, Municípios e Distrito Federal - estão conjugadas de modo complexo, mediante o critério vertical e horizontal de repartição de competências. Estado Federal é a República Federativa do Brasil que representa o todo, dotado de personalidade jurídica de Direito Público Internacional. Já os demais são dotados de autonomia e personalidade jurídica de Direito Interno. O federalismo faz da União uma figura de duas faces, que tanto age em nome próprio como em nome da Federação ao expressar sua voz.

O objetivo do federalismo é a consecução e harmônica manutenção da unidade e diversidade entre as partes federadas, alcançadas pela efetiva distribuição de competências legislativas e de rendas entres os entes federados no corpo da própria Constituição Federal, o que enseja autonomia aos entes federados - a capacidade de auto-organização pela sua própria legislação e administração, sem subordinação imediata aos demais entes federados.

A CF/88 arrolou expressamente as atribuições materiais da União (art. 21) e suas competências legislativas privativas (art. 22). Aos Estados-membros, o constituinte utilizou a técnica da competência remanescente não enumerada (art. $25, \S 1^{\circ}$ ). Já os Municípios receberam poderes estabelecidos indicativamente, quando presente o interesse local, tanto para legislar como administrar, bem como suplementar a legislação federal e estadual no que couber (art. 30). 
Inovou o constituinte ao positivar a competência concorrente entre a União, os Estados e o DF, a chamada divisão vertical de competências legislativas (art. 24) e as competências administrativas comuns (art. 23).

A competência legislativa privativa da União (art. 22) congrega a chamada repartição horizontal de competência, pois cabe tão somente ao ente federado legislar sobre a matéria então arrolada.

Aos Estados-membros, o constituinte deferiu a autonomia legislativa condicionada tão somente pelos princípios estruturantes da Constituição Federal de 1988 - entre esses, a forma republicana, o sistema representativo, o regime democrático, a temporariedade das funções eletivas, a separação de Poderes, a autonomia municipal, a prestação de constas da administração pública direta e indireta e as regras de pré-ordenação institucional. Deve, pois, o legislador estadual observar esse amálgama organizacional mínimo à Federação. A competência dos Estados é ampla, pois, em tese, tem legitimidade para atuar em todas as searas não enumeradas à União e aos Municípios.

O Distrito Federal é também ente federado e congrega as competências próprias dos Estados-membros e as Municipais. Contudo, a União reservou para si a tutela e a legislação sobre organização judiciária do Ministério Público, da Defensoria Pública, da polícia civil e militar, bem como do corpo de bombeiros.

O Município é tido como ente federado pela $\mathrm{CF} / 88$. Tem, portanto, autonomia para se auto-organizar mediante legislação própria, a Lei Orgânica do Município, e autoadministrarse. Deverá também observar as condicionantes fundamentais federais e estaduais.

Outra inovação constitucional positivada pela $\mathrm{CF} / 88$ é a competência concorrente, onde mais de um ente político atua de modo conjunto - tanto na competência administrativa (art. 23 da CF), como na seara legislativa (art. 24 da CF).

Por meio da competência concorrente, a União estabelece as normas gerais sobre o assunto, ao passo que os Estados legislam em caráter complementar. Normas gerais são regramentos de interesse comum aos entes federados; devem tomar a forma de lei quadro, apto a ser pormenorizado por normas estaduais. O art. $24, \S 3^{\circ}$, por sua vez, contempla a competência estadual legislativa plena, no caso de inexistência de lei federal sobre o tema; ao passo que o $\S 4^{\circ}$ dispõe que a superveniência de lei federal que discipline normas gerais suspende a eficácia da lei estadual, no que lhe for contrária. Congregam-se, pois, forças de 
duas ordens: a de centralização de um lado (normas gerais) e a de descentralização d'outro (provinda dos Estados, através de normas particulares aos seus interesses).

Das competências materiais (art. 21,23) advêm as chamadas competências legislativas impróprias ou decorrentes, as quais surgem por via transversa, isto é, emanam da competência administrativa, da necessidade de regular os interesses que lhe são deferidos constitucionalmente. Têm lugar ante a necessidade de se dar alicerce legislativo para o exercício da competência material. Para a União, a atividade administrativa volta-se para definir linhas de desenvolvimento nacional, com nítida importância ao papel de planejamento e coordenação de políticas públicas. Aos Estados cabem as tarefas remanescentes, cumulada com a exploração de serviço local de gás canalizado, e aos Municípios as atribuições que congregam interesse local.

Quanto às competências comuns, leis complementares provindas da União (para cada assunto de interesse) fixarão normas de cooperação entre os entes federados, onde caberá à União apontar as diretrizes da política pública e aos demais entes a definição de suas peculiaridades - típica mecanismo do federalismo cooperativo.

Regiões metropolitanas, aglomerações urbanas e microregiões são criadas por lei complementar estadual; já o planejamento e a execução de funções de interesse comum deverão ser realizadas pela entidade criada.

A CF/88 firmou a passagem de uma forma extrema de federalismo centralizado, construída sob o regime autoritário, para uma forma de federalismo cooperativo ou de equilíbrio. O nosso federalismo tem trabalhado com a centralização e descentralização concomitantemente (e não de forma excludente) cujo processo ainda está em fase de amadurecimento. Assim, o federalismo brasileiro continua a desenvolver-se como fenômeno político-jurídico vivo em franca evolução, cuja proliferação das competências legislativas e respectiva interpretação dos operadores do Direito e da própria Justiça ditará os rumos do nosso federalismo no futuro.

O estudo da Hermenêutica Constitucional é fundamental para visualizar os resultados que otimizem as diretrizes constitucionais do federalismo, aplicáveis às competências legislativas para a solução de conflitos legislativos entre os entes federados.

A evolução da dogmática jurídica tomou consciência de que a interpretação jurídica vai além da norma, congrega o contexto social, os fins dirigidos pela norma e os princípios 
que fundamentam o sistema. A aplicação do Direito requer a compreensão da dinâmica relação desses fatores, pois a aplicação é justamente o final do processo interpretativo. Assim, tem-se como nítida a distinção entre o texto normativo (o dispositivo ou enunciado) e o seu conteúdo (a norma jurídica que se aflora), sendo aquele objeto da interpretação e esse o resultado.

A solução de conflitos legislativos situa-se em regra no plano da aplicação. A ponderação tem papel de grande importância na análise dos conflitos, seja entre princípios ou valores e até mesmo na interpretação de regras. Seu propósito é solucionar conflitos normativos de modo mais sensato à realidade e aos valores envolvidos, de forma que não se despreze qualquer das regras em confronto, mas se adote postura que privilegie o valor de maior magnitude constitucional à luz das circunstâncias do caso - e, assim, privilegiar a técnica argumentativa e crítica própria do Direito, como fenômeno sócio-político e normativo.

A natureza do federalismo requer a multiplicidade de centros normativos, o que enseja a intersecção de normas. Caberá ao intérprete conciliar os conflitos normativos, segundo as diretrizes da Carta Constitucional e uma visão macro do ordenamento jurídico. O dever de coerência está muito mais para o juiz do que para o legislador, tanto porque esse trabalha com a criação do Direito e aquele com a sua aplicação, ao passo que a solução do conflito situa-se no plano da aplicação do Direito. Em eventual choque de legislações de entes federados, a regra é a permanência de ambas as normas, pois o federalismo concebe por essência a convivência de ambas - tratando-se de antinomias aparentes.

A leitura para a solução de conflitos legislativos entre entes federados deve sempre partir do foco constitucional. Diante dos critérios clássicos para a solução de antinomias, o critério da especialidade prevalece, pois se harmoniza com o critério da preponderância do interesse jurídico tutelado pela legislação frente ao feixe de competências constitucionais.

A dogmática jurídica clama pela complementariedade dos métodos interpretativos para melhor amparar o intérprete na solução dos conflitos. Para a solução de conflitos legislativos entre entes federados, deve-se destacar as seguintes técnicas de interpretação constitucional: a interpretação conforme a constituição; o princípio da proporcionalidade, que interage com o princípio da concordância prática ou da harmonização; e, por fim, o princípio da correção funcional. 
O principal parâmetro para os limites da interpretação consiste na exigência de que toda e qualquer interpretação constitucional seja compatível com a amplitude de sentidos projetada pelo texto do enunciado em cotejo ao programa normativo (e não valorativo) do sistema.

Diante de conflitos legislativos entre diferentes entes federados, o intérprete deverá analisar a legislação a partir de: i) o objeto jurídico que a legislação em exame está a tutelar; ii) a finalidade dessa legislação frente à especificidade de seus regramentos. E daí conectar a legislação em exame às cláusulas de competência dos entes federados, segundo a seguinte orientação:

a) as normas municipais só serão válidas quando interajam com leis federais ou estaduais, se legítimo o interesse municipal e a matéria regrada seja suscetível de suplementação municipal (art. 30, II);

b) no âmbito das competências concorrentes, as normas nacionais provindas da União se sobrepõem às demais, desde que não interfiram no caráter acidental e particular das normas estaduais - pois aquelas devem ser normas gerais (art. $24, \S 1^{\circ}$ ). Há de se respeitar a margem de espaço próprio dos Estados-membros para que possam regulamentar interesses que lhe são peculiares, sob o amálgama próprio do federalismo, a preservação da diversidade na unidade. Uma vez particularizadas as normas próprias da União no âmbito da competência concorrente, essas só valerão para a própria União, especialmente para questões tributárias, financeiras e administrativas. Não é tida como norma particular a norma que admita ou proíba determinada conduta;

c) em sede de competência administrativa comum, todos os entes federados têm competência para firmar regulamentação normativa, ao passo que leis complementares fixarão o regime de cooperação entre os entes federados. Caberá, pois, ao ente central coordenar tais atividades;

d) a averiguação da competência legislativa estadual deve ser efetivada à luz das disposições constitucionais que firmam o feixe de competência de cada ente federado em sintonia com o princípio da conformidade funcional.

e) os Tratados Internacionais repercutem sobre os conflitos legislativos entre os entes federados. Pois, sob o prisma internacional, a República Federativa do Brasil representa todas as pessoas políticas internas. Tal constatação tem expressiva importância para a solução de 
conflitos entre os demais entes federados, pois poderão surgir dos Tratados Internacionais, obrigações gerais às quais os demais entes federados deverão cumprir, eis que vinculados em nome da Federação.

Os tratados internacionais não revogam a legislação interna; apenas prevalecem. Esta continua válida, mas tem sua aplicação contida pelo tratado internacional, em um processo de autolimitação desenvolvido pelo próprio Estado soberano, tendo em vista o acordado com outro Estado. 


\section{BIBLIOGRAFIA}

ACCIOLY, Hidelbrando; SILVA, Geraldo Eulálio do Nascimento. Manual de direito internacional público. 12. ed. São Paulo: Saraiva, 1996.

AFFONSO, Rui de Britto. A Federação no Brasil: Impasses e Perspectivas. Revista A Federação em Perspectiva: ensaios selecionados. Fundap, 1995.

ALEXY, Robert. Teoría de los derechos fundamentales. Tradução por Ernesto Garzón Vládes. Madrid: Centro de Estudos Constitucionales, 1993.

AMARAL, Antonio Carlos Rodrigues (Coord.). Tratados internacionais na ordem jurídica brasileira. São Paulo: Aduaneiras, 2005.

AMARAL, Francisco. A interpretação jurídica segundo o Código Civil. Revista do Advogado, São Paulo, n. 98, p. 90-100, jul. 2008.

AMARAL, Rafael Caiado. Peter Häberle e a hermenêutica constitucional: alcance doutrinário. Porto Alegre: Sérgio Antonio Fabris, 2004.

AMARAL JÚNIOR, José Levi de Mello do. Direitos humanos fundamentais: doutrina, prática e jurisprudência. São Paulo: Edifieo, [no prelo].

. Medida Provisória e sua conversão em Lei: a Emenda Constitucional n. 32 e o papel do Congresso Nacional. São Paulo: Revista dos Tribunais, 2004.

ALMEIDA, Fernanda Dias Menezes de. Competências na Constituição de 1988. São Paulo: Atlas, 1991.

ALMEIDA, Fernanda Dias Menezes de. Competências na Constituição de 1988. $2^{\mathrm{a}}$ ed., São Paulo: Atlas, 2000.

ALMEIDA, Fernanda Dias Menezes de. Competências na Constituição de 1988. 4. ed. São Paulo: Atlas, 2007.

ALMEIDA, Maria Hermínia Tavares de. Federalismo e Políticas Sociais. Revista Brasileira de Ciências Sociais. $\mathrm{n}^{\mathrm{o}} 28$, junho de 1995,

ALMEIDA, Rui. Federalismo e Políticas Sociais. Revista Brasileira de Ciências Sociais $\mathrm{n}^{\circ} 28$. São Paulo, junho de 1995. 
ALVES, Alaôr Caffé. Regiões metropolitanas, aglomerações urbanas e microrregiões: novas dimensões constitucionais da organização do Estado brasileiro. Revista de Direito Ambiental, São Paulo, v. 6, n. 21, p. 57-82, jan./mar. 2001.

ANTUNES, Paulo de Bessa. Direito Ambiental. 6 ed. Rio de Janeiro: Lúmen Júris, 2002.

ARAGÃO, Alexandre. Direito dos serviços públicos. Rio de Janeiro: Forense, 2007.

ARAÚJO, Edmir Netto de. Contrato administrativo. São Paulo: Revista dos Tribunais, 1987.

ARAÚJO, Luiz Alberto David; NUNES JÚNIOR, Vidal Serrano. Curso de direito constitucional. $13^{\mathrm{a}}$ ed. São Paulo: Saraiva, 2009.

ARAÚJO, Marcelo Labanca C. de. O condomínio legislativo. Dissertação (Mestrado em Direito Constitucional) Universidade Federal de Pernambuco, Recife, 2001.

ÁVILA, Humberto. Teoria dos Princípios: da definição à aplicação dos princípios jurídicos. $8^{a}$ ed. São Paulo: Malheiros, 2008.

BARACHO, José Alfredo de Oliveira. O princípio da subsidiariedade: conceito e evolução. Revista de Direito Administrativo, n. 200, p. 21-54, abr./jun. 1995.

BARCELlOS, Ana Paula de. Alguns parâmetros normativos para a ponderação constitucional. A nova interpretação constitucional: ponderação, direitos fundamentais e relações privadas. Rio de Janeiro: Renovar, 2003, p. 49-118.

BARROS, Sérgio Resende de. Atualidade hermenêutica. Disponível em:

$<$ http://www.srbarros.com.br>. Acesso em: outubro de 2010.

. Ciência política. Disponível em: <http://www.srbarros.com.br>. Acesso em: outubro de 2010.

. Contribuição dialética para o constitucionalismo. Campinas: Milleniun, 2007.

Teoria do Estado. Disponível em: <http://www.srbarros.com.br>. Acesso em: outubro de 2010.

BARROSO, Luis Roberto (Org.). A nova interpretação constitucional: ponderação, direitos fundamentais e relações privadas. Rio de Janeiro: Renovar, 2003.

- Interpretação e aplicação da Constituição: fundamentos de uma dogmática constitucional transformadora. 6. ed. rev., atual. e ampl. São Paulo: Saraiva, 2003. 
.O direito constitucional e a efetividade de suas normas: limites e possibilidades da Constituição Brasileira. 6. ed. Rio de Janeiro: Renovar, 2002.

BASTOS, Celso Seixas Ribeiro; MARTINS, Ives Gandra. Comentários à Constituição do Brasil. São Paulo: Saraiva, 1993. v. 3.

Curso de direito constitucional. 11. ed. São Paulo: Saraiva, 1989.

BELLAN, Daniel V. O instituto da qualificação no direito tributário internacional. Revista Dialética de Direito Tributário, São Paulo, n. 120, p. 43-59, set. 2005.

BERCOVICI, Gilberto. A problemática da Constituição Dirigente: algumas considerações sobre o caso brasileiro. Revista de Informação Legislativa, Brasília, v. 36, n.142, p. 35-51, abr./jun. 1999.

. Dilemas do Estado Federal Brasileiro. Porto Alegre: Livraria do Advogado,

2004.

BETTI Emílio. La interpretación da la ley y de los actos jurídicos. Madrid: EDERSA, 1975.

.Teoria generalle della interpretazione. Milano: Giuffrè, 1955. v. 2.

BLEICHER Josef. Hermenêutica Contemporânea. Tradução: Maria G. Segurado. Lisboa: Edições 70, [s.d.].

BOBBIO, Norberto. Estado, governo, sociedade - para uma teoria geral da política. Tradução de Marco Aurélio Nogueira. Rio de Janeiro: Paz e Terra, 1987.

. O positivismo jurídico: lições de filosofia do direito. Tradução e notas de Márcio Pugliesi, Edson Bini e Carlos Rodrigues. São Paulo: Ícone, 2006.

. Teoria do ordenamento jurídico. 10. ed. Tradução de Maria Celeste Santos. Brasília: Editora da UnB, 1999.

BONAVIDES, Paulo. O caminho para um federalismo das regiões. Revista de Informação Legislativa, Brasília, v. 17, n. 65, p. 115-126, jan./mar. 1980.

O planejamento e os organismos regionais como preparação a um federalismo das regiões. Revista de Informação Legislativa, Brasília, n. 31, p. 53-78, jul./set. 1971.

Curso de Direito Constitucional. 15 ed. São Paulo: Malheiros, 2003.

BROTONS, Antônio Remiro. Derecho Internacional. Madrid: McGrawHill, 1997. 
CAVEDON, Fernanda de Salles et al. Função ambiental da propriedade urbana e áreas de preservação permanente: a proteção das águas no ambiente urbano. In: CONGRESSO INTERNACIONAL DE DIREITO AMBIENTAL, 7º, 2003, São Paulo. Direito, água e vida = Law, water and the web of life: 2 a 6/06/2003. Antonio Herman Benjamin (Org.). São Paulo : Imprensa Oficial do Estado de São Paulo, 2006, v. 2, p. 173-195.

CAGGIANO, Mônica Hermann Salem. Sistemas eleitorais x representação política. 1987. Tese (Doutorado apresentada em Direito Político e Econômico) - Faculdade de Direito da Universidade de São Paulo, São Paulo, 1987.

CANOtILHO, J. J. Gomes. Direito constitucional e teoria da constituição. 4. ed. Coimbra: Almedina, 2000.

CARRAZZA, Roque Antonio. Curso de direito constitucional tributário. 17. ed. São Paulo: Malheiros, 2002.

CARVALHO NETO, Menelick de. A hermenêutica constitucional sob o paradigma do Estado Democrático de Direito. Notícia do Direito Brasileiro, Brasília, n. 6, p. 233-250, 1998.

CELLI JÚNIOR, Umberto. Teoria Geral da Integração: em busca de um modelo alternativo. In: MERCADANTE, Araminta de Azevedo; CELLI JÚNIOR, Umberto; ARAÚJO, Leandro Rocha de (Org.). Blocos econômicos e integração na América Latina, África e Ásia. Curitiba: Juruá, 2006, v.1, p. 19-37.

CRETELLA JÚNIOR, José. Comentários à Constituição Brasileira de 1988. Rio de Janeiro: Forense, 1989.

Tratado de direito administrativo. Rio de Janeiro: Forense, 1966. v. 1-5. . Tratado de direito administrativo. Rio de Janeiro: Forense, 1969. v. 6 e 7. . Tratado de direito administrativo. Rio de Janeiro: Forense, 1970. v. 8. Tratado de direito administrativo. Rio de Janeiro: Forense, 1972. v. 10.

CRUZ, Rafael Naranjo de la. La reforma Del sistema de atribuicion de competências en La Ley Fundamental. Revista de Derecho Constitucional Europeu nº6. Jul./Dez. de 2006.

DALLARI, Dalmo de Abreu. Elementos da teoria geral do Estado. São Paulo: Saraiva, 1972. O Estado federal. São Paulo: Ática, 1986. 
DWORKIN, Ronald. Taking rights seriously. Cambridge: Harvard University Press, 1977. FERRAZ, Anna Cândida da Cunha. Conflito entre poderes: o poder congressual de sustar atos normativos do Poder Executivo. São Paulo: Revista dos Tribunais, 1994.

. Mutação, reforma e revisão das normas constitucionais. Cadernos de Direito Constitucional e Ciência Política, São Paulo, v. 2, n. 5, p. 5-24, out./dez. 1993.

. Os tratados e as convenções internacionais de direitos humanos anteriores à Emenda Constitucional n. 45/2004. Revista Mestrado em Direito, Osasco, v. 7, n. 1, p. 117-132, jan./jun. 2007 .

. Poder constituinte do Estado-membro. São Paulo, Revista dos Tribunais, 1979.

. Princípios condicionantes do poder constituinte. Revista de Direito Público, São Paulo, v. 22, n. 92, p. 35-42, out./dez. 1989a.

. Processos informais de mudança da Constituição. São Paulo: Max Limonad, 1986.

. União, Estados e Municípios na Nova Constituição: enfoque jurídico-formal. A Nova

Constituição Paulista. São Paulo: Fundação Faria Lima/Fundação de Desenvolvimento Administrativo, 1989b.

(Coord.). Constituição Federal interpretada: artigo por artigo, parágrafo por parágrafo. Barueri, SP: Manole, 2010.

FERRAZ JÚNIOR, Tércio Sampaio. Introdução à Ciência do direito: técnica, decisão, dominação. São Paulo: Atlas, 1988.

. Princípios Condicionantes do Poder Constituinte. Revista de Direito Público $n^{\circ}$ 92, 1989.

. Uma exegese do artigo 24 da Constituição Federal. Revista Trimestral de Direito Público, São Paulo: Malheiros, p. 16-20, 1994.

FERREIRA FILHO, Manoel Gonçalves. Comentários à Constituição brasileira. 3. ed. São Paulo: Saraiva, 1983.

. Comentários à Constituição brasileira de 1988. São Paulo: Saraiva, 1990a. v. 1.

. Competência concorrente limitada. O problema da conceituação das normas gerais.

Revista de Informação Legislativa, Brasília, v. 25, n. 100, p. 127-162, out./dez. 1988. 
. Curso de direito constitucional. 18. ed. São Paulo: Saraiva, $1990 \mathrm{~b}$.

. O Estado Federal brasileiro à luz da Constituição de 1988. Revista da Faculdade de Direito da Universidade de São Paulo, v. 86, p. 116-118, 1991.

. Princípios fundamentais do direito constitucional: o estado da questão no século XXI, em face do direito comparado e, particularmente, do direito positivo brasileiro. São Paulo: Saraiva, 2009.

FIGUEIREDO NETO, Diogo. Competência concorrente limitada. O problema da conceituação das normas gerais. Revista de Informação Legislativa, Brasília, v. 25, n. 100, out./dez. 1988.

FIGUEIROA, Alfonso Garcia. A teoria do direito em tempos de constitucionalismo. Revista Brasileira de Estudos Constitucionais - RBEC. Belo Horizonte, n. 4, p. 77-102, out./dez. 2007. FRANCISCO, José Carlos. Emendas Constitucionais e limites flexíveis. Rio de Janeiro: Forense, 2003.

FREITAS, Juarez. A melhor interpretação constitucional versus a única resposta correta. In: SILVA, Virgílio Afonso da (Org.). Interpretação constitucional. São Paulo: Malheiros, 2005. GADAMER, Hans-Georg. Verdade e método. Tradução: Flávio Meurer, $7^{\mathrm{a}}$ ed. Petrópolis: Vozes, Bragança Paulista: EDUSF, 2005.

GARCIA, Emerson. Conflitos entre normas constitucionais esboço de uma teoria geral. Rio de Janeiro: Lumen Juris, 2008.

GEBRAN NETO, João Pedro. A aplicação imediata dos direitos e garantias individuais - a busca de uma exegese emancipatória. São Paulo: Revista dos Tribunais, 2002.

GODOI, Marciano Seabra. Os tratados ou convenções internacionais para evitar a dupla tributação e sua hierarquia normativa no direito brasileiro. In: SCHOUERI, Luis Eduardo et al (Coord.). Direito tributário - homenagem a Alcides Jorge da Costa. São Paulo: Quartier Latin, v. 2, p. 975-1010, 2003.

HÄBERLE, Peter. Hermenêutica constitucional: a sociedade aberta dos intérpretes da Constituição. Porto Alegre: Fabris, 2004.

HAMILTON, Alexander; MADISON, James; JAY, John. O federalista. Tradução de Heitor de Almeida Herrera. Brasília: Editora da UnB, 1984. 
HORTA, Raul Machado. A autonomia do Estado-membro no direito constitucional brasileiro. Belo Horizonte: Graf Santa Maria, 1964.

Organização constitucional do federalismo. Revista de Informação Legislativa, Brasília, v. 22, n. 87, p. 5-22, jul./set.1985.

. Repartição de competências na Constituição Federal de 1988. Revista Trimestral de Direito Público, São Paulo: Malheiros, n. 2. p. 1993.

KATO, Evandro Takeshi. A Lei n. 8.249/92 e a perda de mandato do Chefe do Executivo por decisão judicial em razão de ato de improbidade administrativa. 2004. Tese (Doutorado em Direito do Estado) - Faculdade de Direito da Universidade de São Paulo, São Paulo, 2004.

KELSEN, Hans. General theory of law and state. Cambridge-Massachusetts: Harvard University Press, 1949. . Teoria Geral do Direito e do Estado. 2 ed. Barcelona: Bosch, 1934.

. Teoria pura do direito. 2. ed. Tradução de João Baptista Machado. São Paulo: Martins Fontes, 1991.

KLEINHEISTERKAMP, Jan. A interpretação uniforme do direito comunitário. In: RODAS, João Grandino (Coord.). Contratos Internacionais. 3 ed. Revista dos Tribunais, 2002.

LARENZ, Karl. Derecho de obligaciones. Madri: Revista de Derecho Privado, 1958. . Metodologia da ciência do direito. Lisboa: Fundação Calouste Gulbenkian, 1978.

LOBO, Paulo Luiz Neto. Competência legislativa concorrente dos Estados-membros na Constituição de 1988. Revista de Informação Legislativa, Brasília, v. 26, n. 101, jan./mar.1989.

LOEWENSTEIN, Karl. Teoria de la Constituición. Barcelona: Ariel, 1986.

MACHADO Antonio Claudio da Costa (org). Constituição Federal interpretada: artigo por artigo, parágrafo por parágrafo /Anna Cândida da Cunha Ferraz (coordenadora). Barueri, SP: Manole, 2010.

MACHADO, Paulo Affonso Leme. Direito Ambiental Brasileiro. 11 ed. São Paulo: Malheiros, 2003.

MALUF, Sahid. Teoria geral do Estado. 8. ed. São Paulo: Sugestões Literárias, 1974. 
MARQUES NETO, Floriano A. Agências reguladoras independentes: fundamentos e seu regime jurídico. Belo Horizonte: Fórum, 2005a.

A Nova Regulamentação dos Serviços Públicos. Revista Eletrônica de Direito Administrativo Econômico, $\mathrm{n}^{\circ}$ 01, fev. 2005b. Salvador.

MENDES. Gilmar Ferreira; COELHO, Inocêncio; BRANCO, Paulo G. Curso de direito constitucional. São Paulo: Saraiva, 2007.

MEIRELLES, Hely Lopes. Direito administrativo brasileiro. 14. ed. São Paulo: Revista dos Tribunais, 1989.

Direito municipal brasileiro. 4. ed. São Paulo: Revista dos Tribunais, 1981.

MONTESQUIEU, Charles-Louis de Secondat, Baron de. O espírito das leis: as formas de governo, federação, a divisão dos poderes, presidencialismo versus parlamentarismo. 6. ed. Tradução de Pedro Vieira Mota. São Paulo, Saraiva, 1999.

MORAES, Alexandre de (Coord.). Agências reguladoras. São Paulo: Atlas, 2002.

.Tratados internacionais na Constituição de 1988. In: AMARAL, Antonio Carlos Rodrigues (Coord.). Tratados internacionais na ordem jurídica brasileira. São Paulo: Lex Editora, 2005. p. 31-46

MOREIRA, Neto Diogo de Figueiredo. Competência concorrente limitada. O problema da conceituação das normas gerais. . Revista de Informação Legislativa, Brasília, v. 25, n. 100, p. 127-162, out./dez. 1988.

MOTTA, Fabrício Macedo. A função normativa da administração pública brasileira. 2007. Tese (Doutorado em Direito do Estado ) - Faculdade de Direito da Universidade de São Paulo, São Paulo, 2007.

MÜLLER, Friedrich. Métodos de trabalho do Direito Constitucional. 3. ed. Trad. Peter Naumann. Rio de Janeiro: Renovar, 2005.

OTERO, Cleber Sanfelice. A lei complementar como instrumento de realização de segurança jurídica. 2002. 174 f. Dissertação (Mestrado em Direito Constitucional) - Instituição Toledo de Ensino de Bauru, Bauru, 2002. 
PEDREIRA, Christina Almeida. Instrumentos legítimos à implementação das competências constitucionais administrativas comuns. Revista Brasileira de Estudos Constitucionais, Belo Horizonte, ano 2, n. 6, abr/jun. 2008. p. 19-48.

PINTO, Paulo Brossar de Souza. O impeachment: aspectos da responsabilidade política do Presidente da República. 3. ed. São Paulo: Saraiva, 1992.

RAMOS, Elival Silva. Federação - competência legislativa (normas gerais de competência da União e competência supletiva dos Estados: a questão dos agrotóxicos). Revista de Direito Público, São Paulo, ano XIX, n. 77, jan./mar. 1986.

.Parâmetros dogmáticos do ativismo judicial em matéria constitucional. 2009. Tese apresentada à Faculdade de Direito da Universidade de São Paulo (Fadusp), visando ao provimento de cargo de Professor Titular ao Departamento de Direito de Estado. São Paulo, 2009.

REALE, Miguel. Fontes e modelos do direito - para um novo paradigma hermenêutico. São Paulo: Saraiva, 1994.

REMIRO BROTONS, Antonio et al. Derecho internacional. Madrid: McGraw-Hill, 1997.

REZEK, José Francisco. Direito internacional público. 7. ed. São Paulo: Saraiva, 1998.

ROCHA, Carmen Lúcia Antunes. República e Federação no Brasil. Belo Horizonte: Del Rey, 1997.

RODAS, João Grandino (Coord.). Contratos internacionais. 3. ed. São Paulo: Revista dos Tribunais, 2002.

RODRIGUES, Nina T. D. Novos rumos para o federalismo: contribuições para a sua melhoria. 2007. Tese (Doutorado em Direito do Estado) - Faculdade de Direito da Universidade de São Paulo, São Paulo, 2007.

SAMPAIO, Gustavo Castro. O Estado regulador. 2007. Dissertação (Mestrado em Direito do Estado) - Faculdade de Direito da Universidade de São Paulo, São Paulo, 2007.

SARMENTO Daniel. O neoconstitucionalismo no Brasil: riscos e possibilidades. Revista Brasileira de Estudos Constitucionais. n 9, Belo Horizonte, jan/mar 2009, p. 95-133, 2009. 
SERRANO, Pedro Estevam Alves Pinto. Região Metropolitana e seu regime constitucional. São Paulo: Editora Verbatim, 2009.

SCHOUERI, Luís Eduardo. Direito tributário internacional - qualificação e substituição tributação no Brasil, de rendimentos provenientes de sociedade de pessoas residentes na Alemanha. Revista Dialética de Direito Tributário, São Paulo: Dialética, n. 54, 2000.

. Notas sobre os Tratados Internacionais sobre tributação. In: AMARAL, Antonio Carlos Rodrigues. Tratados Internacionais na Ordem Jurídica Brasileira. São Paulo: Lex Editora, 2005.

. Planejamento fiscal através de acordos de bitributação - treaty shopping. 1994. Tese (Doutorado em Direito Econômico e Financeiro) - Faculdade de Direito da Universidade de São Paulo, São Paulo, 1994. . Tratados e convenções internacionais sobre tributação. IBDT - Direito Tributário Atual. São Paulo: Dialética, n. 17, 2003.

SCHWARTZ, Bernard. O federalismo norte-americano atual. Rio de Janeiro: Forense Universitária, 1984.

SILVA, José Afonso. Curso de direito constitucional positivo. 2. ed. São Paulo: Revista dos Tribunais, 1984 .

. Curso de direito constitucional positivo. 5. ed. São Paulo: Revista dos Tribunais, 1989.

. Curso de direito constitucional positivo. 29 ed. São Paulo: Malheiros, 2006.

SILVA, Virgílio Afonso da. Interpretação Constitucional. São Paulo: Malheiros, 2005.

SILVA, De Plácido e. Vocábulo jurídico. 19. ed. São Paulo: Forense, 2002.

SOUTO, Marco Vilena. Desestatização, privatização, concessões, terceirização e regulação. 4. ed. Rio de Janeiro: Lumen Juris, 2001.

SOUZA, Rubens Gomes; ATALIBA, Geraldo; CARVALHO, Paulo de Barros. Comentários ao Código Tributário nacional. São Paulo: Educ/RT, 1975.

STRECK, Lenio. Apresentação. In: TRIBE, Laurence; DORF, Michael. Hermenêutica Constitucional. Belo Horizonte: Del Rey, 2007. 
TAVARES, André Ramos. Aporias acerca do "condomínio legislativo" no Brasil: uma análise a partir do STF. Revista Brasileira de Estudos Constitucionais - RBEC. Belo Horizonte, ano 2, n. 6, p. 161-188, abr./jun. 2008.

TEMER, Michel. Elementos de direito constitucional. 10. ed. São Paulo: Malheiros, 1993.

TORRES, Heleno T. Aplicação dos tratados e convenções internacionais em matéria tributária no direito brasileiro. In: AMARAL, Antonio C. R. (Coord.). Tratados internacionais na ordem jurídica brasileira. São Paulo: Lex Editora, 2005.

TRIBE, Laurence; DORF, Michael. Hermenêutica Constitucional. Tradução de Amarílis Birchal. Belo Horizonte: Del Rey, 2007.

TOJAL, Sebastião. Controle Judicial da Atividade Normativa das Agências Reguladoras. In: MORAES, Alexandre (Coord). Agências Reguladoras, São Paulo: Atlas, 2002, p. 162 e 170.

TUSHNET, Mark. Weak Courts Strong Rights: Jucidial Review and Social Welfare Rights in Comparative Making Law. Princeton: Princeron University Press, 2008.

VASQUES, Denise. Competências legislativas concorrentes: prática legislativa da União e dos Estados-membros e jurisprudência do Supremo Tribunal Federal. 2007. Dissertação (Mestrado em Direito do Estado ) - Faculdade de Direito da Universidade de São Paulo, São Paulo, 2007.

VOGEL, Klaus. Harmonia decisória e problemática da qualificação nos acordos de bitributação. In: SCHOUERI, Luís Eduardo; ZILVETI, Fernando Aurélio (Coord.). Direito tributário - estudos em homenagem a Brandão Machado. São Paulo: Dialética, 1998.

Problemas na interpretação de acordos de bitributação. In: SCHOUERI, Luis Eduardo (Coord.). Direito tributário - homenagem a Alcides Jorge da Costa. São Paulo: Quartier Latin, 2003, v. 2, p. $961-973$

XAVIER, Alberto. Direito tributário internacional. 6. ed. Rio de Janeiro: Forense, 2004a.

. Direito tributário internacional do Brasil: tributação das operações internacionais. 5. ed. atual. Rio de Janeiro: Forense, 2004b.

YAMASHITA, Douglas. Evolução da convenção-modelo da OCDE e a Influência de suas alterações na Interpretação nos Tratados para evitar a bitributação. In: AMARAL, Antonio 
(Coord.). Tratados Internacionais na ordem Jurídica Brasileira. São Paulo: Lex Editora, 2005.

ZAGREBELSKY, Gustavno. Diritto Costituzionale: Il Sistemma delle Fonti del Diritto. 1. ed. [1988]. Torino: Unione Tipográfico-Editrice Torinese, 1998. v.1. 